\title{
Variations in selenium concentrations by photochemical and temperature-controlled iron cycles
}

\author{
Kendi L. Waltemyer
}

Follow this and additional works at: https://researchrepository.wvu.edu/etd

\section{Recommended Citation}

Waltemyer, Kendi L., "Variations in selenium concentrations by photochemical and temperature-controlled iron cycles" (2015). Graduate Theses, Dissertations, and Problem Reports. 6893.

https://researchrepository.wvu.edu/etd/6893

This Thesis is protected by copyright and/or related rights. It has been brought to you by the The Research Repository @ WVU with permission from the rights-holder(s). You are free to use this Thesis in any way that is permitted by the copyright and related rights legislation that applies to your use. For other uses you must obtain permission from the rights-holder(s) directly, unless additional rights are indicated by a Creative Commons license in the record and/ or on the work itself. This Thesis has been accepted for inclusion in WVU Graduate Theses, Dissertations, and Problem Reports collection by an authorized administrator of The Research Repository @ WVU. For more information, please contact researchrepository@mail.wvu.edu. 


\title{
VARIATIONS IN SELENIUM CONCENTRATIONS BY PHOTOCHEMICAL AND TEMPERATURE-CONTROLLED IRON CYCLES
}

\author{
Kendi L. Waltemyer
}

Thesis submitted

\begin{abstract}
to the Eberly College of Arts and Sciences
at West Virginia University

in partial fulfillment of the requirements

for the degree of
\end{abstract}

Master of Science

in

Geology

Dorothy Vesper, Ph.D., Chair

Louis McDonald, Ph.D.

Helen Lang, Ph.D.

Department of Geology and Geography

\author{
Morgantown, West Virginia \\ 2015
}

Keywords: geochemistry, diel, cycles, iron, Fe, selenium, Se

Copyright 2015 Kendi L. Waltemyer 


\section{ABSTRACT \\ Variations in Selenium Concentrations by Photochemical and Temperature-Controlled Iron Cycles}

\section{Kendi L. Waltemyer}

Selenium (Se) concentrations in natural waters may vary over a 24-hour (diel) period in response to temperature changes. Diel cycles of Se have not been reported in coal mine drainage (CMD) waters, and understanding the mechanisms of Se concentration variations in CMD is important for predicting Se fate and mobility. Iron (Fe) is often associated with CMD, and diel cycles of dissolved Fe species concentrations and/or the formation of Fe oxyhydroxide minerals may impact Se mobility. Experiments were conducted in a laboratory setting between July 2014 and April 2015 to determine if selenite $\left(\mathrm{Se}^{\mathrm{IV}}\right)$ concentration changes could be detected in the same experiments with solid 2-line ferrihydrite (a synthesized Fe oxyhydroxide mineral) and dissolved Fe species concentration changes. Light and temperature controls were used to drive Fe species and $\mathrm{Se}^{\mathrm{IV}}$ concentration changes. Each experiment differed in solution type (Fe-only, Se-only, or Fe-Se combined), length, temperature, and light conditions. Samples were collected and analyzed for $\mathrm{Se}^{\mathrm{IV}}$, total $\mathrm{Se}, \mathrm{Fe}^{\mathrm{II}}$ and total $\mathrm{Fe} . \mathrm{Se}^{\mathrm{IV}}$ concentration changes were found to be directly correlated with temperature in both Se-only and Fe-Se solutions. The cycles were more pronounced in the presence of 2-line ferrihydrite. Temperature-dependent sorption of $\mathrm{Se}^{\mathrm{IV}}$ onto 2-line ferrihydrite was the likely cause of $\mathrm{Se}^{\mathrm{IV}}$ cycles. $\mathrm{Se}^{\mathrm{IV}}$ did not cycle with temperature in vessel solutions with $\mathrm{pH}$ values greater than 3 , indicating that $\mathrm{pH}$ is a critical factor in $\mathrm{Se}^{\mathrm{IV}}$ cycling. The experiments were completed at $\mathrm{pH}$ values around 3, underwent significant temperature changes ranging from $2.2^{\circ} \mathrm{C}$ to $36.5^{\circ} \mathrm{C}$, and contained solid Fe oxyhydroxide (2-line ferrihydrite). These conditions are known to exist in some CMD waters, suggesting that $\mathrm{Se}^{\mathrm{IV}}$ diel cycles may exist in these settings. 


\section{ACKNOWLEDGEMENTS}

I would like to thank the faculty at WVU who have helped to further my education in the geosciences. A special thanks goes to my advisor, Dorothy Vesper; Ph.D., and my committee members, Louis McDonald; Ph.D. and Helen Lang; Ph.D., for their support and guidance both in and out of the classroom. I would also like to thank Cecil Slaughter from the Office of Surface Mining Reclamation and Enforcement (OSMRE) for providing funding for this project through the OSM-WV Acid Drainage Technology Initiative (ADTI) cooperative agreement. Special thanks also goes to Lisa Lohr, my "selenium buddy", for spending countless hours working with me in the lab and always keeping a smile on my face. I would also like to thank Habib H. Bravo Ruiz, R. Christopher Nicholson, and Derek Weicht for their help with running the temperature control system for my experiments. Thanks also go to my parents and grandparents for always believing in me and supporting my academic goals. Lastly, a huge thank you goes to my fiancé, Derek Weicht, for his encouragement, love, and support throughout my graduate school career. 


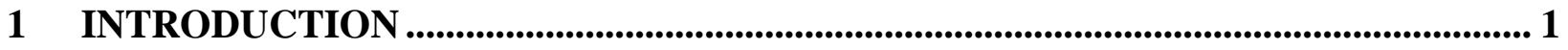

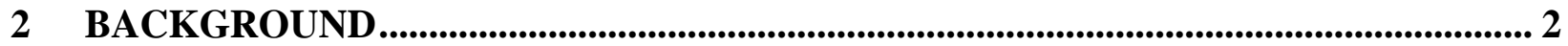

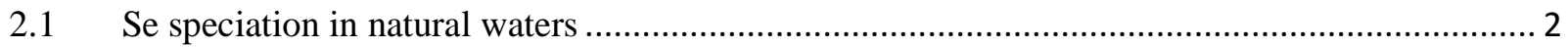

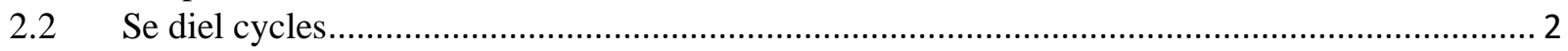

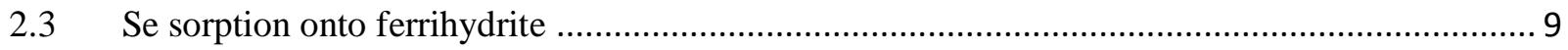

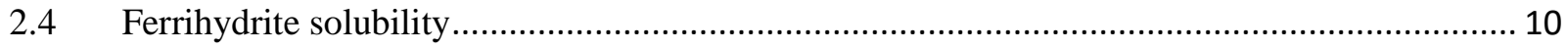

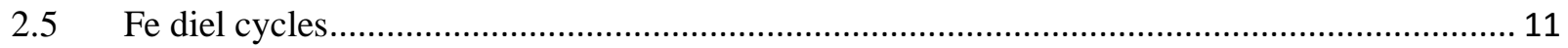

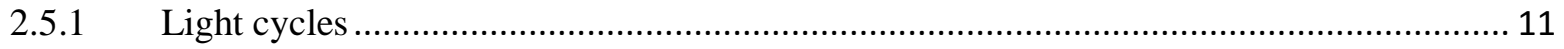

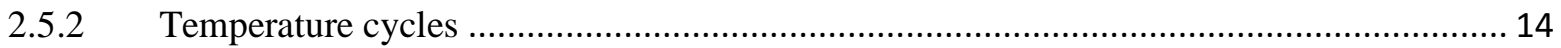

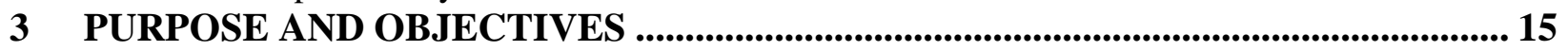

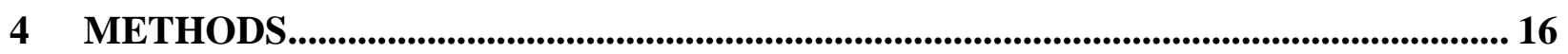

$4.1 \quad$ Experimental overview and layout ………………………………………………… 16

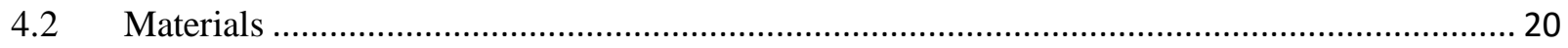

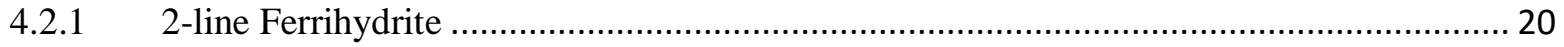

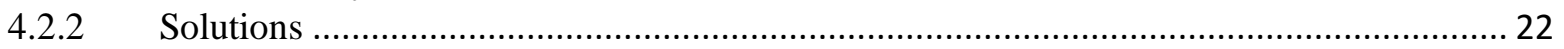

4.3 Data logging and meter measurements...................................................................... 22

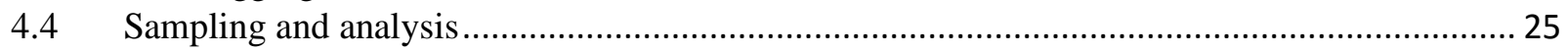

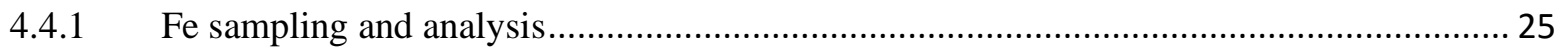

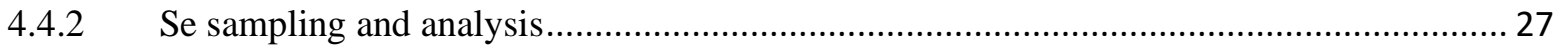

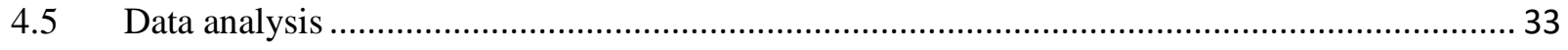

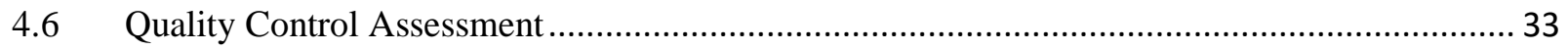

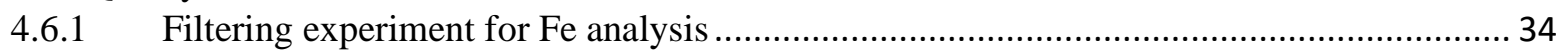

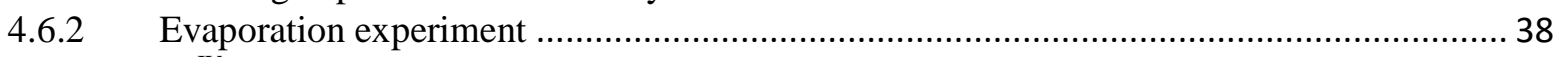

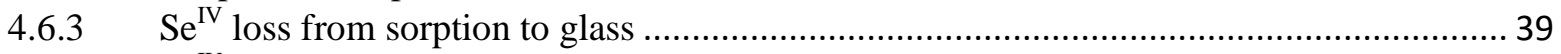

4.6.4 $\quad \mathrm{Se}^{\mathrm{IV}}$ desorption from glass ..................................................................................... 39

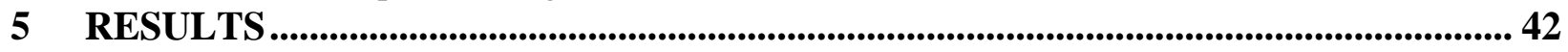

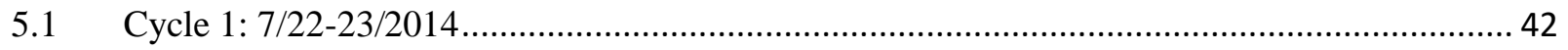

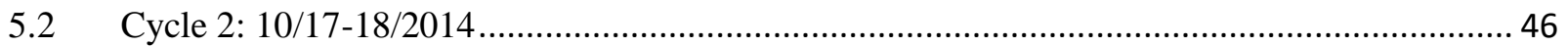

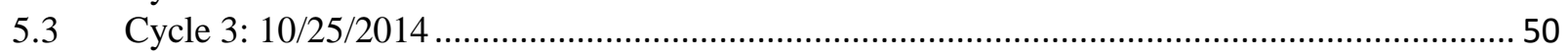

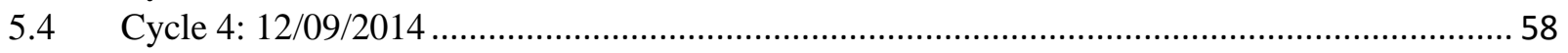

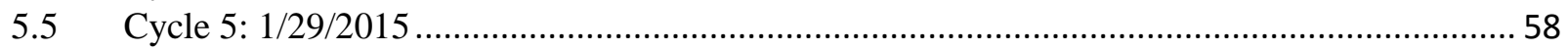

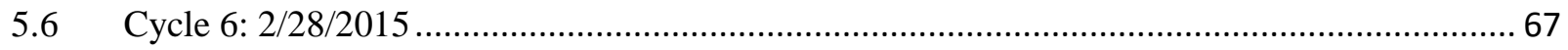

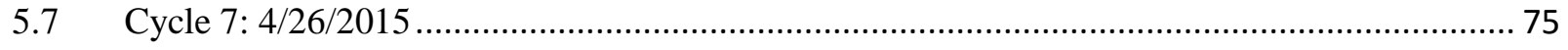

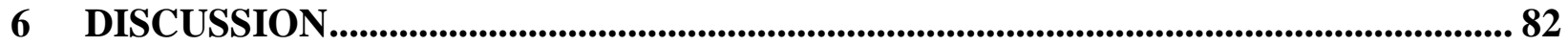

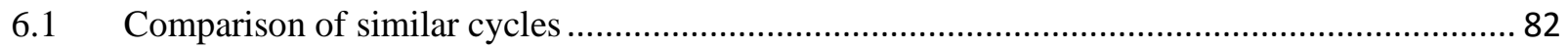

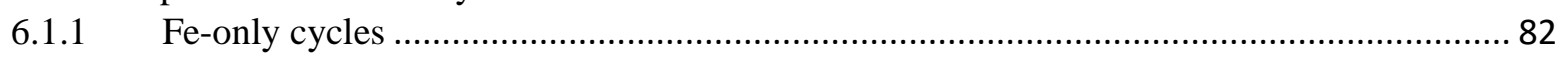

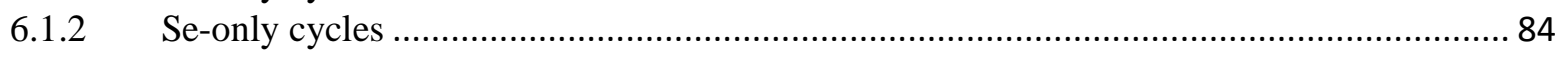

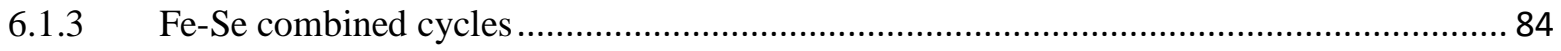

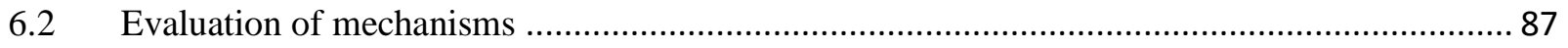

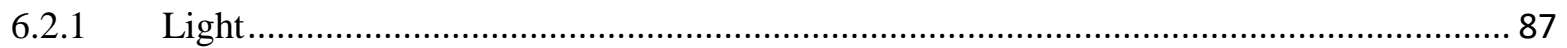

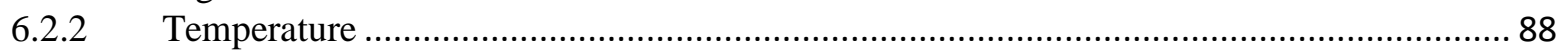

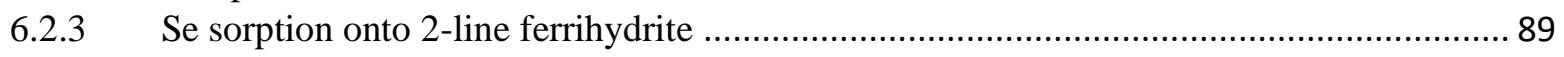

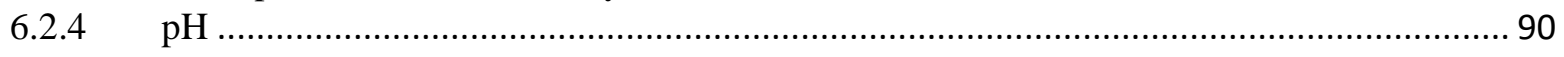

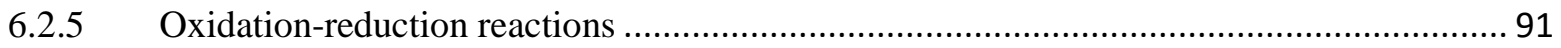




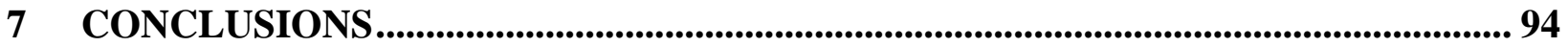

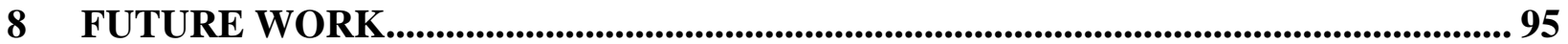

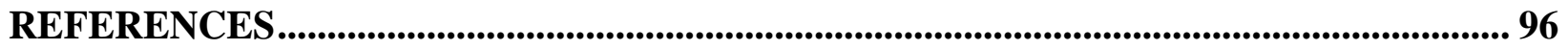

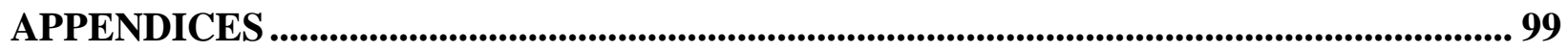




\section{List of Tables}

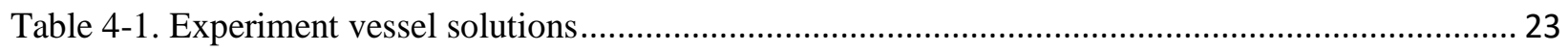

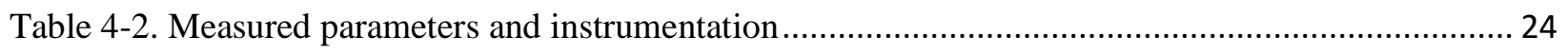

Table 4-3. Ferrozine method sample to solution ratios for $\mathrm{Fe}^{\mathrm{II}}$ and $\mathrm{Fe}(\mathrm{total})$ analysis ........................... 28

Table 4-4. Ratios of sample, DI water, and $6 \mathrm{M} \mathrm{HCl}$ prepared for $\mathrm{Se}^{\mathrm{IV}} \mathrm{HG}-\mathrm{ICP}-\mathrm{OES}$ analysis................ 29

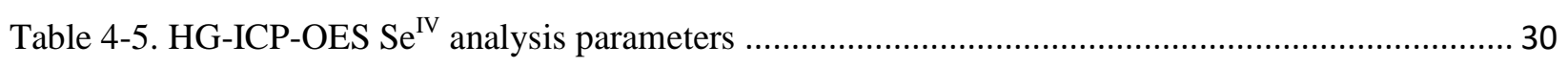

Table 4-6. Filtering experiment for Fe analysis: A comparison of unfiltered and filtered samples ........... 35

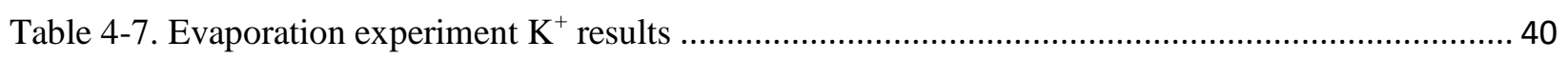

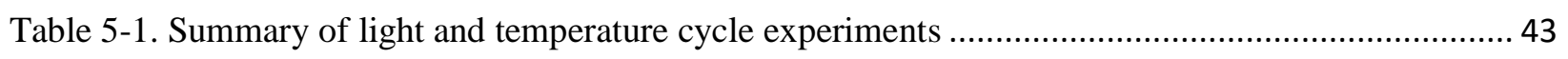

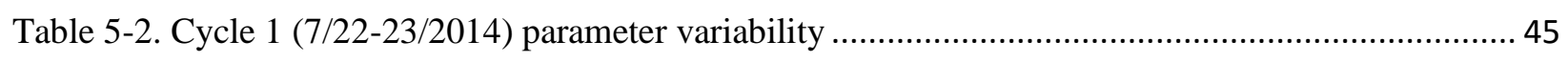

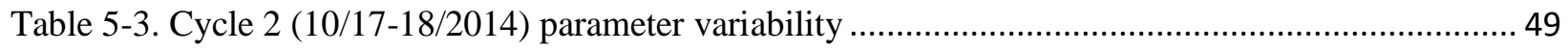

Table 5-4. Cycle 3 (10/25/2014) parameter variability ...................................................................... 53

Table 5-5. $\mathrm{Se}^{\mathrm{IV}}$ versus temperature linear regression results ......................................................... 55

Table 5-6. Conditional Enthalpies of Sorption for Cycle 3 …........................................................ 57

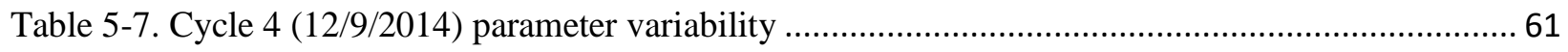

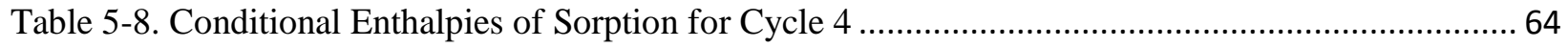

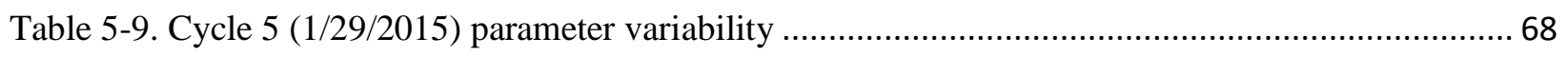

Table 5-10. Cycle 6 (2/28/2015) parameter variability ….............................................................. 71

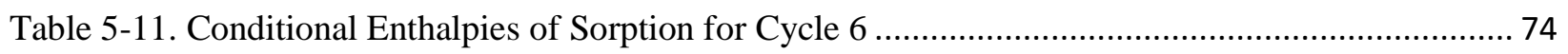

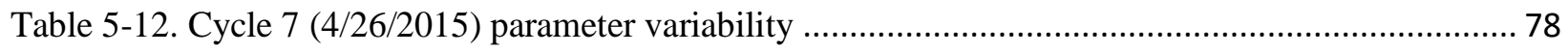

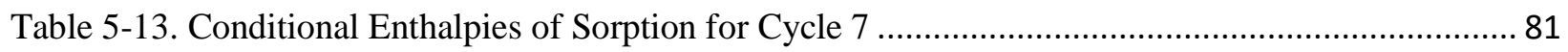

Table 6-1. Summary of cycles by group (Fe-only, Se-only, and Fe-Se combined) ................................ 83

Table 6-2. Comparison of Se-only and Fe-Se cycles .................................................................... 85 


\section{List of Figures}

Figure 2-1. Redox potential-pH diagram for a dissolved Se species concentration of $10^{-6} \mathrm{M}$ at $1 \mathrm{~atm}$ and $25{ }^{\circ} \mathrm{C}$. Figure modified from Reddy and DeLaune, 2008. 3

Figure 2-2. Selenite ion speciation plot, where $\mathrm{Se}^{\mathrm{IV}}$ concentration equals $3.80 \times 10^{-6} \mathrm{M}(300 \mu \mathrm{g} / \mathrm{L})$, temperature equals $25^{\circ} \mathrm{C}$, and ionic strength equals $0.1 \mathrm{M}$. Figure constructed using Visual MINTEQ, version 3.1 (Allison et al., 1991).

Figure 2-3. Selenate ion speciation plot, where $\mathrm{Se}^{\mathrm{VI}}$ concentration equals $3.80 \times 10^{-6} \mathrm{M}(300 \mu \mathrm{g} / \mathrm{L})$, temperature equals $25^{\circ} \mathrm{C}$, and ionic strength equals $0.1 \mathrm{M}$. Figure constructed using Visual MINTEQ, version 3.1 (Allison et al., 1991).

Figure 2-4. Summary of Dicataldo et al. (2011) results for Se diel cycles in a freshwater wetland of the Great Salt Lake, Utah. The gray shaded areas indicate nightime hours (dark conditions). Figure modified from Dicataldo et al., 2011 .............................................................. 6

Figure 2-5. Summary of Carling et al. (2011) results for Se diel cycles in two freshwater wetlands (ADC-1 and ADC-2) of the Great Salt Lake, Utah. The gray shaded areas indicate nightime hours (dark conditions). Figure modified from Carling et al., 2011.

Figure 2-6. (a) Solubility curves for $0.5 \mathrm{~g}$ of ferrihydrite, $\mathrm{Fe}(\mathrm{OH})_{3}$, at $10{ }^{\circ} \mathrm{C}, 25^{\circ} \mathrm{C}$, and $35{ }^{\circ} \mathrm{C}$ showing $\mathrm{Fe}$ (total) concentrations and (b) Solubility diagram for $0.5 \mathrm{~g}$ of ferrihydrite at $25^{\circ} \mathrm{C}$ showing all Fe species, where ionic strength equals 0.1 M. Figure constructed using Visual MINTEQ, version 3.1 (Allison et al., 1991). 12

Figure 2-7. Redox potential-pH diagram for the Fe-O-H2O system for a dissolved Fe species concentration of $10^{-6} \mathrm{M}$ at $1 \mathrm{~atm}$ and $25^{\circ} \mathrm{C}$. Figure modified from Drever, 1997. 13

Figure 4-1. Schematic of temperature control system. Arrows indicate water flow direction. 17

Figure 4-2. Photograph of completed temperature and light control systems. RT is room temperature. $\mathrm{V} 1, \mathrm{~V} 2, \mathrm{~V} 3$, and V4 are the vessel numbers.

Figure 4-3. Schematic of light control system

Figure 4-4. Synthesis of 2-line ferrihydrite. (a) 40 grams $\mathrm{Fe}\left(\mathrm{NO}_{3}\right)_{3} \cdot 9 \mathrm{H}_{2} \mathrm{O}$ dissolved in $500 \mathrm{~mL}$ DI water; (b) $300 \mathrm{~mL} \mathrm{KOH}$ added to solution; (c) Solid solution soaking in dialysis membrane tubing; (d) Solid drying in crucible; (e) Dried 2-line ferrihydrite crushed with mortar and pestle; and (f) 2-line ferrihydrite sieved through a $125 \mu \mathrm{m}$ sieve.

Figure 4-5. Ferrozine method calibration samples for $\mathrm{Fe}^{\mathrm{II}}$ analysis. $\mathrm{Fe}^{\mathrm{II}}$ concentrations decrease from left to right as indicated by the different shades of purple.

Figure 4-6. Multimode sample introduction system (MSIS) using vapor generation mode (modified from Marathon Scientific, 2007).

Figure 4-7. Photograph of the filtering experiment for Fe analysis. Vessels are numbered 1 through 6 from left to right. Vessels 1 and 6 are beakers, and vessels 2 through 5 are jacketed reaction vessels.

Figure 4-8. Results of the filtering experiment for Fe analysis showing the comparison between unfiltered and filtered samples analyzed for $\mathrm{Fe}^{\mathrm{II}}$ and $\mathrm{Fe}$ (total). Standard deviations are represented by error bars for six replicate samples. 
Figure 5-1. Cycle 1 (7/22-23/2014) results. A single vessel was set up for this experiment containing Fe-only solution. The straight, solid line indicates the MDL for $\mathrm{Fe}^{\mathrm{II}}$ analysis $(0.02 \mathrm{mg} / \mathrm{L}$ $\mathrm{Fe}^{\mathrm{II}}$ ) on the HACH DR2800 Spectrophotometer. The gray shaded areas indicate when the light was turned off (dark conditions).

Figure 5-2. Cycle 2 (10/17-18/2014) results with all vessels (V1-V4) graphed together. All vessels contained Fe-only solutions. The solid red lines indicate the MDL for $\mathrm{Fe}^{\mathrm{II}}$ analysis $(0.02$ $\mathrm{mg} / \mathrm{L} \mathrm{Fe}^{\mathrm{II}}$ ) on the HACH DR2800 Spectrophotometer. Fe(total) is equal to the sum of Fe ${ }^{\mathrm{II}}$ and $\mathrm{Fe}^{\mathrm{III}}$ species. Standard deviations are represented by error bars for triplicate samples. The gray shaded areas indicate when the light was turned off (dark conditions).

Figure 5-3. Cycle 2(10/17-18/2014) results with all vessels (V1-V4) graphed separately. All vessels contained Fe-only solutions. The solid red lines indicate the MDL for $\mathrm{Fe}^{\mathrm{II}}$ analysis $(0.02$ $\mathrm{mg} / \mathrm{L} \mathrm{Fe}^{\mathrm{II}}$ ) on the HACH DR2800 Spectrophotometer. Fe(total) is equal to the sum of Fe ${ }^{\mathrm{II}}$ and $\mathrm{Fe}^{\mathrm{III}}$ species. Standard deviations are represented by error bars for triplicate samples. The gray shaded areas indicate when the light was turned off (dark conditions). Note that the $\mathrm{pH}$ was adjusted in Vessel 3 during hour 13.

Figure 5-4. Cycle 3 (10/25/2014) results with all vessels (V1-V4) graphed together. All vessels contained Fe-Se solutions. The solid red line indicates the MDL for $\mathrm{Fe}^{\mathrm{II}}$ analysis $(0.02$ $\mathrm{mg} / \mathrm{L} \mathrm{Fe}^{\mathrm{II}}$ ) on the HACH DR2800 Spectrophotometer. Fe(total) is equal to the sum of $\mathrm{Fe}^{\mathrm{II}}$ and $\mathrm{Fe}^{\mathrm{III}}$ species. Standard deviations are represented by error bars for triplicate samples. The gray shaded area indicates that the light was turned off for this experiment (dark conditions).

Figure 5-5. Cycle 3 (10/25/2014) results with all vessels (V1-V4) graphed separately. All vessels contained $\mathrm{Fe}-\mathrm{Se}$ solutions. The solid red lines indicate the MDL for $\mathrm{Fe}^{\mathrm{II}}$ analysis $(0.02$ $\mathrm{mg} / \mathrm{L} \mathrm{Fe}^{\mathrm{II}}$ ) on the HACH DR2800 Spectrophotometer. Fe(total) is equal to the sum of Fe ${ }^{\mathrm{II}}$ and $\mathrm{Fe}^{\mathrm{III}}$ species. Standard deviations are represented by error bars for triplicate samples. The gray shaded area indicates that the light was turned off for this experiment (dark conditions).

Figure 5-6. Cycle $3(10 / 25 / 2014)$ relationship between $\mathrm{Se}^{\mathrm{IV}}$ concentrations and temperature. The start and end of each cycle is labeled next to the corresponding data symbol (red square). Red squares represent the temperature increasing series, whereas the blue circles represent the temperature decreasing series. Solid red lines are linear regression lines for the temperature increasing series. Solid blue lines are linear regression lines for the temperature decreasing series. The black dashed lines indicate the order in which samples were collected over time. The gray shaded area indicates that the light was turned off for this experiment (dark conditions).

Figure 5-7. Enthalpy of sorption plot for Cycle 3 (10/25/2014). Increasing temperature series (solid symbols and lines) and decreasing temperature series (open symbols and dashed lines) data are plotted separately for each vessel. Vessel numbers are labelled V1 through V4. 56

Figure 5-8. Cycle 4 (12/09/2014) results with all vessels (V1-V4) graphed together. Vessels 1 and 2 contained Fe-only solutions, whereas Vessels 3 and 4 contained Fe-Se solutions. The solid blue lines indicate the MDL for $\mathrm{Se}^{\mathrm{IV}}$ analysis $\left(5 \mu \mathrm{g} / \mathrm{L} \mathrm{Se}^{\mathrm{IV}}\right)$ on the Perkin Elmer Optima 2100 DV ICP-OES. Standard deviations are represented by error bars for triplicate samples. 
Figure 5-9. Cycle 4 (12/09/2014) results with all vessels (V1-V4) graphed separately. Vessels 1 and 2 contained Fe-only solutions, whereas Vessels 3 and 4 contained Fe-Se solutions. The solid blue lines indicate the MDL for $\mathrm{Se}^{\mathrm{IV}}$ analysis $\left(5 \mu \mathrm{g} / \mathrm{L} \mathrm{Se}^{\mathrm{IV}}\right)$ on the Perkin Elmer Optima 2100 DV ICP-OES. Standard deviations are represented by error bars for triplicate samples.

Figure 5-10. Cycle 4 (12/9/2014) relationship between $\mathrm{Se}^{\mathrm{IV}}$ concentrations and temperature. The start and end of each cycle is labeled next to the corresponding data symbol (red square). Red squares represent the first temperature increasing series, blue circles represent the temperature decreasing series, and green triangles represent the second temperature increasing series. Solid red lines are linear regression lines for the first temperature increasing series. Solid blue lines are linear regression lines for the temperature decreasing series. The black dashed lines indicate the order in which samples were collected over time.

Figure 5-11. Enthalpy of sorption plot for Cycle 4 (12/9/2014). The increasing temperature series 1 (solid symbols and solid lines), decreasing temperature series (open symbols and dashed lines), and increasing temperature series 2 (patterned symbols and solid lines) data are plotted separately for each vessel. Vessel numbers are labelled V3 and V4.

Figure 5-12. Cycle 5 (1/29/2015) results with all vessels (V1-V4) graphed together. All vessels contained Se-only solutions. Standard deviations are represented by error bars for triplicate samples

Figure 5-13. Cycle 5 (1/29/2015) results with all vessels (V1-V4) graphed separately. All vessels contained Se-only solutions. Standard deviations are represented by error bars for triplicate samples 66

Figure 5-14. Cycle 6 (2/28/2015) results with all vessels (V1-V4) graphed together. Vessels 1 and 2 contained Fe-only solutions, whereas Vessels 3 and 4 contained Fe-Se solutions. The solid red line indicates the MDL for $\mathrm{Fe}^{\mathrm{II}}$ analysis $\left(0.02 \mathrm{mg} / \mathrm{L} \mathrm{Fe}^{\mathrm{II}}\right)$ on the HACH DR2800 Spectrophotometer. The solid blue line indicates the MDL for Se ${ }^{\mathrm{IV}}$ analysis $\left(5 \mu \mathrm{g} / \mathrm{L} \mathrm{Se}^{\mathrm{IV}}\right)$ on the Perkin Elmer Optima 2100 DV ICP-OES. Standard deviations are represented by error bars for triplicate samples. The gray shaded area indicates that the light was turned off for this experiment (dark conditions)....

Figure 5-15. Cycle 6 (2/28/2015) results with all vessels (V1-V4) graphed separately. Vessels 1 and 2 contained Fe-only solutions, whereas Vessels 3 and 4 contained Fe-Se solutions. The solid red lines indicate the MDL for $\mathrm{Fe}^{\mathrm{II}}$ analysis $\left(0.02 \mathrm{mg} / \mathrm{L} \mathrm{Fe}^{\mathrm{II}}\right)$ on the HACH DR2800 Spectrophotometer. The solid blue lines indicate the MDL for $\mathrm{Se}^{\mathrm{IV}}$ analysis $\left(5 \mu \mathrm{g} / \mathrm{L} \mathrm{Se}^{\mathrm{IV}}\right)$ on the Perkin Elmer Optima 2100 DV ICP-OES. Standard deviations are represented by error bars for triplicate samples. The gray shaded area indicates that the light was turned off for this experiment (dark conditions). 
Figure 5-16. Cycle 6 (2/28/2015) relationship between $\mathrm{Se}^{\mathrm{IV}}$ concentrations and temperature. The start and end of each cycle is labeled next to the corresponding data symbol (red square). Red squares represent the first temperature increasing series, blue circles represent the temperature decreasing series, and green triangles represent the second temperature increasing series. Solid red lines are linear regression lines for the first temperature increasing series. Solid blue lines are linear regression lines for the temperature decreasing series. The black dashed lines indicate the order in which samples were collected over time. The gray shaded area indicates that the light was turned off for this experiment (dark conditions).

Figure 5-17. Enthalpy of sorption plot for Cycle 6 (2/28/2015). The increasing temperature series 1 (solid symbols and solid lines), decreasing temperature series (open symbols and dashed lines), and increasing temperature series 2 (patterned symbols and solid lines) data are plotted separately for each vessel. Vessel numbers are labelled V3 and V4.

Figure 5-18. Cycle 7 (4/26/2015) results with all vessels (V1-V4) graphed together. All vessels contained Se-only solutions. Standard deviations are represented by error bars for triplicate samples

Figure 5-19. Cycle 7 (4/26/2015) results with all vessels (V1-V4) graphed separately. All vessels contained Se-only solutions. Standard deviations are represented by error bars for triplicate samples

Figure 5-20. Cycle 7 (4/26/2015) relationship between $\mathrm{Se}^{\mathrm{IV}}$ concentrations and temperature. The start and end of each cycle is labeled next to the corresponding data symbol (red square). Red squares represent the first temperature increasing series, blue circles represent the temperature decreasing series, and green triangles represent the second temperature increasing series. Solid red lines are linear regression lines for the first temperature increasing series. Solid blue lines are linear regression lines for the temperature decreasing series. Solid green lines are linear regression lines for the second temperature increasing series. The black dashed lines indicate the order in which samples were collected over time.

Figure 5-21. Enthalpy of sorption plot for Cycle 7 (4/26/2015). Increasing temperature (solid symbols and lines) and decreasing temperature (open symbols and dashed lines) data are plotted separately for each vessel. Vessel numbers are labelled V1 through V4.

Figure 6-1. Gibbs Free Energy $\left(\Delta \mathrm{G}_{\mathrm{R}}\right)$ calculated using thermodynamic data from Stumm and Morgan (1996) for $\left[\mathrm{Se}^{\mathrm{IV}}\right]=\left[\mathrm{Se}^{\mathrm{VI}}\right]=3.8 \times 10^{-6} \mathrm{M}$ and $\left[\mathrm{Fe}^{\mathrm{III}}\right]=\left[\mathrm{Fe}^{\mathrm{II}}\right]=9 \times 10^{-6} \mathrm{M}$. Activityconcentration corrections not included. Modified from the final OSMRE report (Vesper et al., 2015). 


\section{List of Appendices}

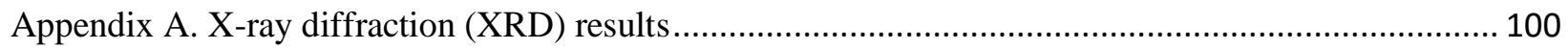

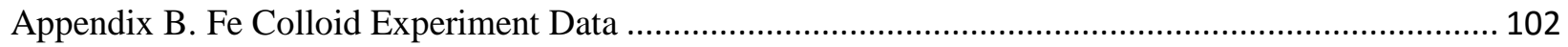

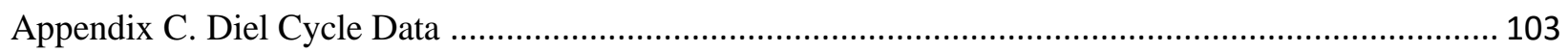

Appendix C-1. Cycle 1 (7/22/2014) Data.......................................................................... 103

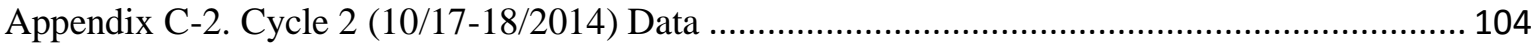

Appendix C-3. Cycle 3 (10/25/2014) Data ........................................................................... 110

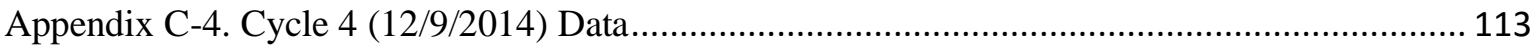

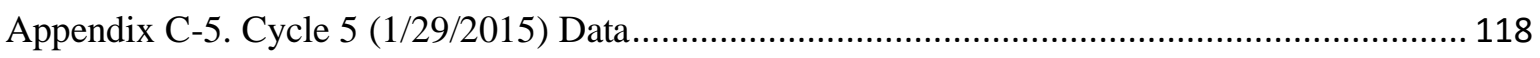

Appendix C-6. Cycle 6 (2/28/2015) Data.......................................................................... 120

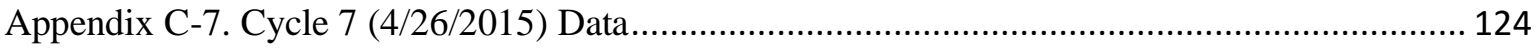




$\begin{array}{ll}\text { List of Acronyms and Abbreviations } \\ \text { CMD } & \text { Coal mine drainage } \\ \text { DI water } & \text { Deionized water } \\ \text { HFO } & \text { Hydrous ferrous oxides } \\ \text { HG } & \text { Hydride Generation } \\ \text { HX } & \text { Hydroxylamine hydrochloride } \\ \text { ICP-OES } & \text { Inductively Coupled Plasma - Optical Emission Spectroscopy } \\ \text { LOD } & \text { Limit of detection } \\ \text { MDL } & \text { Method detection limit } \\ \text { MSIS } & \text { Multimode Sample Introduction System } \\ \text { pHPZC } & \text { Point of zero charge } \\ \text { RSD } & \text { Relative standard deviation } \\ \text { RT } & \text { Room temperature } \\ \text { USEPA } & \text { United States Environmental Protection Agency } \\ \text { XRD } & \text { X-ray diffraction } \\ \Delta \mathbf{G}_{\mathbf{R}} & \text { Gibbs free energy of reaction } \\ \Delta \mathbf{H}_{\text {ads }} & \text { Conditional enthalpy of sorption }\end{array}$

\section{List of Chemical Species}

$\mathrm{Fe}^{\text {II }} \quad$ Ferrous iron, Fe in the + II oxidation state, including both dissolved and colloidal species unless specified otherwise in text.

Fe $^{\text {III }} \quad$ Ferric iron, $\mathrm{Fe}$ in the +III oxidation state, including both dissolved and colloidal species unless specified otherwise in text.

Fe(total) Total iron, including both dissolved and colloidal $\mathrm{Fe}^{\mathrm{II}}$ and $\mathrm{Fe}^{\mathrm{III}}$ species unless specified otherwise in text.

$\mathrm{Se}^{\mathrm{IV}} \quad$ Selenite, Se in the +IV oxidation state, including protonated and deprotonated $\mathrm{Se}^{\mathrm{IV}}$ species $\left(\mathrm{H}_{2} \mathrm{Se}^{\mathrm{IV}} \mathrm{O}_{3}, \mathrm{HSe}^{\mathrm{IV}} \mathrm{O}_{3}{ }^{-}\right.$, and $\left.\mathrm{Se}^{\mathrm{IV}} \mathrm{O}_{3}^{-2}\right)$

$\mathrm{Se}^{\mathrm{VI}} \quad$ Selenate, $\mathrm{Se}$ in the $+\mathrm{VI}$ oxidation state, including protonated and deprotonated $\mathrm{Se}^{\mathrm{VI}}$ species $\left(\mathrm{HSe}^{\mathrm{VI}} \mathrm{O}_{4}{ }^{-}\right.$or $\mathrm{Se}^{\mathrm{VI}} \mathrm{O}_{4}{ }^{-2}$ )

Se(total) Total dissolved selenium, including both $\mathrm{Se}^{\mathrm{IV}}$ and $\mathrm{Se}^{\mathrm{VI}}$ species 


\section{INTRODUCTION}

Selenium (Se) is a naturally occurring element found in the Earth's crust. Leaching of $\mathrm{Se}$ into the natural environment occurs from anthropogenic processes like coal mining, the combustion of coal, and the use of Se-enriched agricultural products (Lenz and Lens, 2009). High concentrations of Se are often reported in coal mine drainage (CMD) and may be present at levels above the United States Environmental Protection Agency (USEPA) stream water standard of $5 \mu \mathrm{g} / \mathrm{L}$ (2013). Compared to other rock types, coal can contain up to 300 times more Se (Coleman et al., 1993).

Recent research has demonstrated that Se concentrations in natural waters may vary over a 24-hour (diel) period in response to light and temperature changes (Carling et al., 2011; Dicataldo et al., 2011; Nimick et al., 2011). Understanding the mechanisms of variations in Se concentrations is important for predicting the mobility of Se in the natural environment. Se mobility may be influenced by the presence of other dissolved species and/or mineral formation and dissolution. For example, iron (Fe) is often associated with CMD, and dissolved Fe species and/or the formation of Fe oxyhydroxide minerals may impact Se mobility. Fe associated with CMD is commonly released by the dissolution of pyrite $\left(\mathrm{FeS}_{2}\right)$ (Younger, 2002), and $\mathrm{Fe}$ concentrations are known to cycle over a diel period. A few processes that control the diel cycling of Fe include mineral dissolution and formation, sorption processes, changes in $\mathrm{pH}$, changes in redox state, photochemical reactions, photosynthesis, microbial-mediated reactions, and variations in stream flow (Gammons et al., 2005a; Gammons et al., 2005b; Kimball et al., 1992; McKnight et al., 2001; McKnight et al., 1988; Nimick, 2003). The presence of Fe minerals and the processes that control the diel cycling of dissolved Fe species may directly impact $\mathrm{Se}$ concentrations and cycling. It is well established that selenite $\left(\mathrm{Se}^{\mathrm{IV}}\right)$ and selenate $\left(\mathrm{Se}^{\mathrm{VI}}\right)$, the two more oxidized forms of $\mathrm{Se}$, sorb to $\mathrm{Fe}^{\mathrm{III}}$ oxides and hydroxides, such as hematite, goethite, and ferrihydrite (Balistrieri and Chao, 1987; Duc et al., 2006; Parida et al., 1997; Rovira et al., 2008). However, diel fluctuations in Se concentrations related to sorption or the relationship between Se concentration variations and Fe diel cycles has not been studied extensively. 


\section{BACKGROUND}

\subsection{Se speciation in natural waters}

Four different oxidation states of Se exist: selenide $\left(\mathrm{Se}^{-\mathrm{II}}\right)$, elemental $\mathrm{Se}\left(\mathrm{Se}^{0}\right)$, selenite $\left(\mathrm{Se}^{\mathrm{IV}}\right)$, and selenate $\left(\mathrm{Se}^{\mathrm{VI}}\right)$ (Balistrieri and Chao, 1987). Under oxidizing conditions, Se forms oxyanions in water. $\mathrm{HSe}^{\mathrm{IV}} \mathrm{O}_{3}{ }^{-}$and $\mathrm{Se}^{\mathrm{VI}} \mathrm{O}_{4}{ }^{2-}$ are the thermodynamically favored Se species under oxidizing conditions and in neutral $\mathrm{pH}$ ranges. The kinetics of $\mathrm{Se}^{\mathrm{IV}}$ to $\mathrm{Se}^{\mathrm{VI}}$ oxidation are very slow and are not favorable for $\mathrm{Se}^{\mathrm{IV}}$ to $\mathrm{Se}^{\mathrm{VI}}$ conversion (Torres et al., 2011). Therefore, $\mathrm{Se}^{\mathrm{IV}}$, in the form of $\mathrm{H}_{2} \mathrm{Se}^{\mathrm{IV}} \mathrm{O}_{3}$ is the dominant Se species in natural systems at $\mathrm{pH}$ values less than 2.62, and $\mathrm{HSe}^{\mathrm{IV}} \mathrm{O}_{3}{ }^{-}$, is the most dominant Se species between $\mathrm{pH}$ values of 2.62 and 8.32 (Figures 2-1 and 2-2) (CRC Handbook of Chemistry and Physics, 2003). The biological toxicity of $\mathrm{Se}^{\mathrm{IV}}$ is greater than that of $\mathrm{Se}^{\mathrm{VI}}$, and in natural waters, $\mathrm{Se}^{\mathrm{VI}}$ tends to be the dominant Se species in highly oxidizing conditions and neutral pH ranges (Das et al., 2013) (Figures 2-1 and 2-3).

The $\mathrm{pH}$ of the solution is critical for $\mathrm{Se}^{\mathrm{IV}}$ and $\mathrm{Se}^{\mathrm{VI}}$ acid protonation and deprotonation (Figures 2-1, 2-2, and 2-3). The following dissociation reactions may occur for $\mathrm{Se}^{\mathrm{IV}}$ (Eq. 1 and 2) and $\mathrm{Se}^{\mathrm{VI}}$ (Eq. 3) acids (CRC Handbook of Chemistry and Physics, 2003):

$$
\begin{array}{ll}
\mathrm{H}_{2} \mathrm{Se}^{\mathrm{IV}} \mathrm{O}_{3} \leftrightarrow \mathrm{HSe}^{\mathrm{IV}} \mathrm{O}_{3}^{-}+\mathrm{H}^{+} & \mathrm{K}=10^{-2.62} \\
\mathrm{HSe}^{\mathrm{IV}} \mathrm{O}_{3}^{-} \leftrightarrow \mathrm{Se}^{\mathrm{IV}} \mathrm{O}_{3}^{2-}+\mathrm{H}^{+} & \mathrm{K}=10^{-8.32} \\
\mathrm{HSe}^{\mathrm{VI}} \mathrm{O}_{4}^{-} \leftrightarrow \mathrm{Se}^{\mathrm{VI}} \mathrm{O}_{4}^{-2}+\mathrm{H}^{+} & \mathrm{K}=10^{-1.66}
\end{array}
$$

\subsection{Se diel cycles}

Dicataldo et al. (2011) reported diel cycles of Se during three sampling events (September 2005, May 2006, and August 2007) in a freshwater wetland of the Great Salt Lake in Utah (Figure 2-4). Se(total) (the sum of all dissolved Se species) concentrations displayed a different diel pattern for each sampling event. In September 2005, filtered Se(total) concentrations increased at night and decreased during the day, ranging from 0.9 to $1.3 \mu \mathrm{g} / \mathrm{L}$. In May 2006, filtered Se(total) and unfiltered Se(total) concentrations had the opposite signal, decreasing at night and increasing during the day, with Se(total) concentrations ranging from 


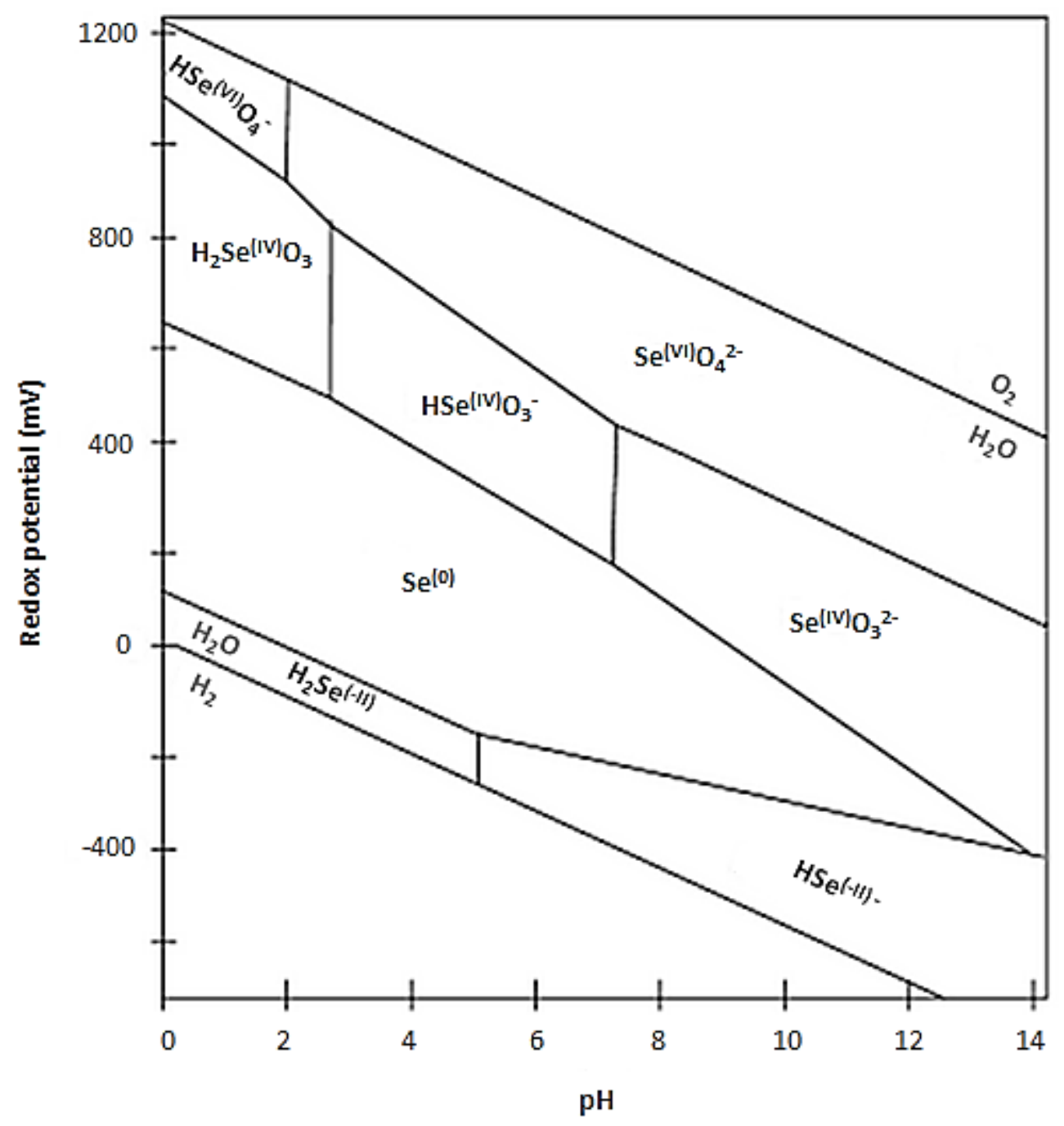

Figure 2-1. Redox potential-pH diagram for a dissolved Se species concentration of $10^{-6} \mathrm{M}$ at $1 \mathrm{~atm}$ and $25^{\circ} \mathrm{C}$. Figure modified from Reddy and DeLaune, 2008. 


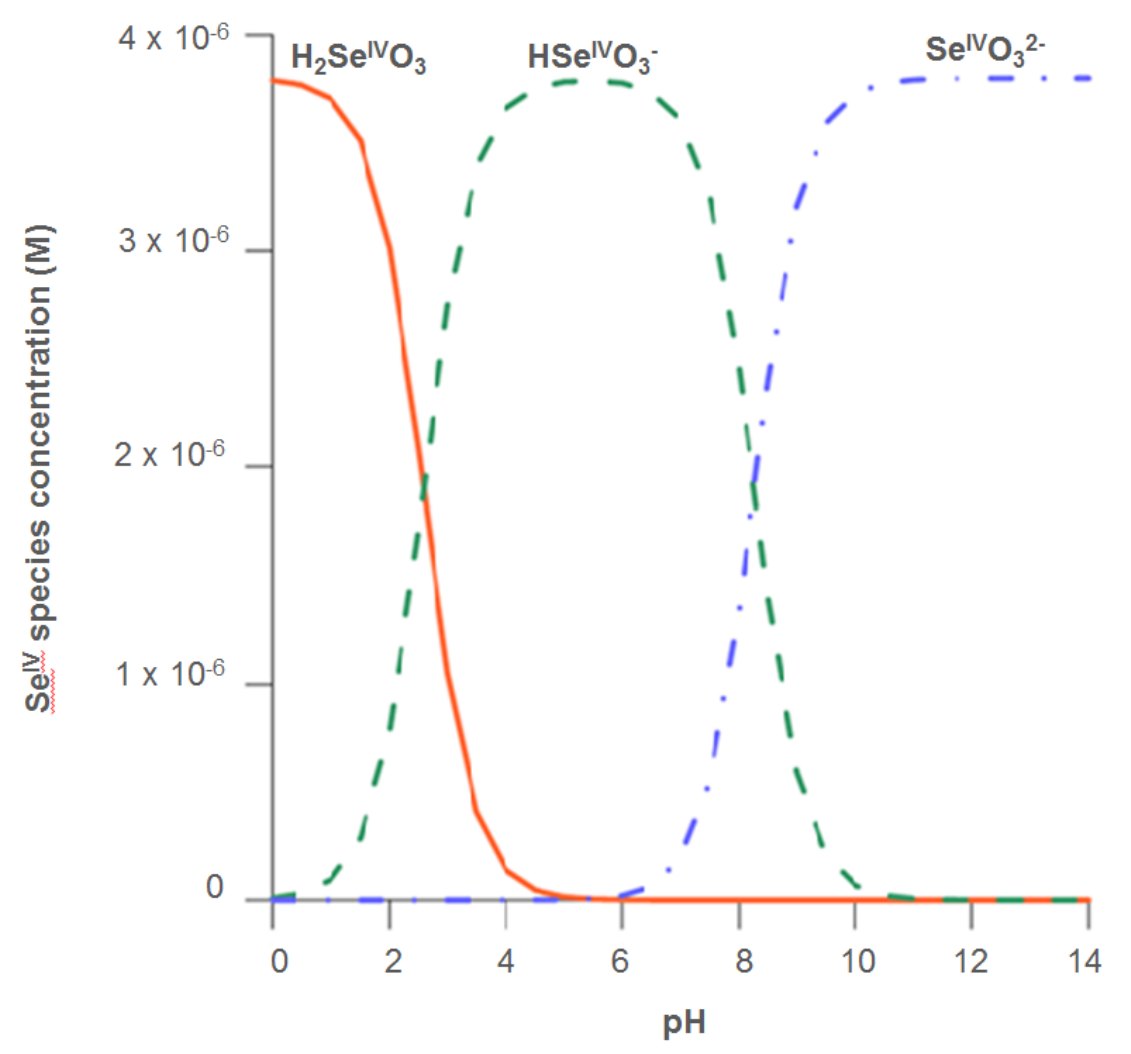

Figure 2-2. Selenite ion speciation plot, where $\mathrm{Se}^{\mathrm{IV}}$ concentration equals $3.80 \times 10^{-6} \mathrm{M}$ $(300 \mu \mathrm{g} / \mathrm{L})$, temperature equals $25^{\circ} \mathrm{C}$, and ionic strength equals $0.1 \mathrm{M}$. Figure constructed using Visual MINTEQ, version 3.1 (Allison et al., 1991). 


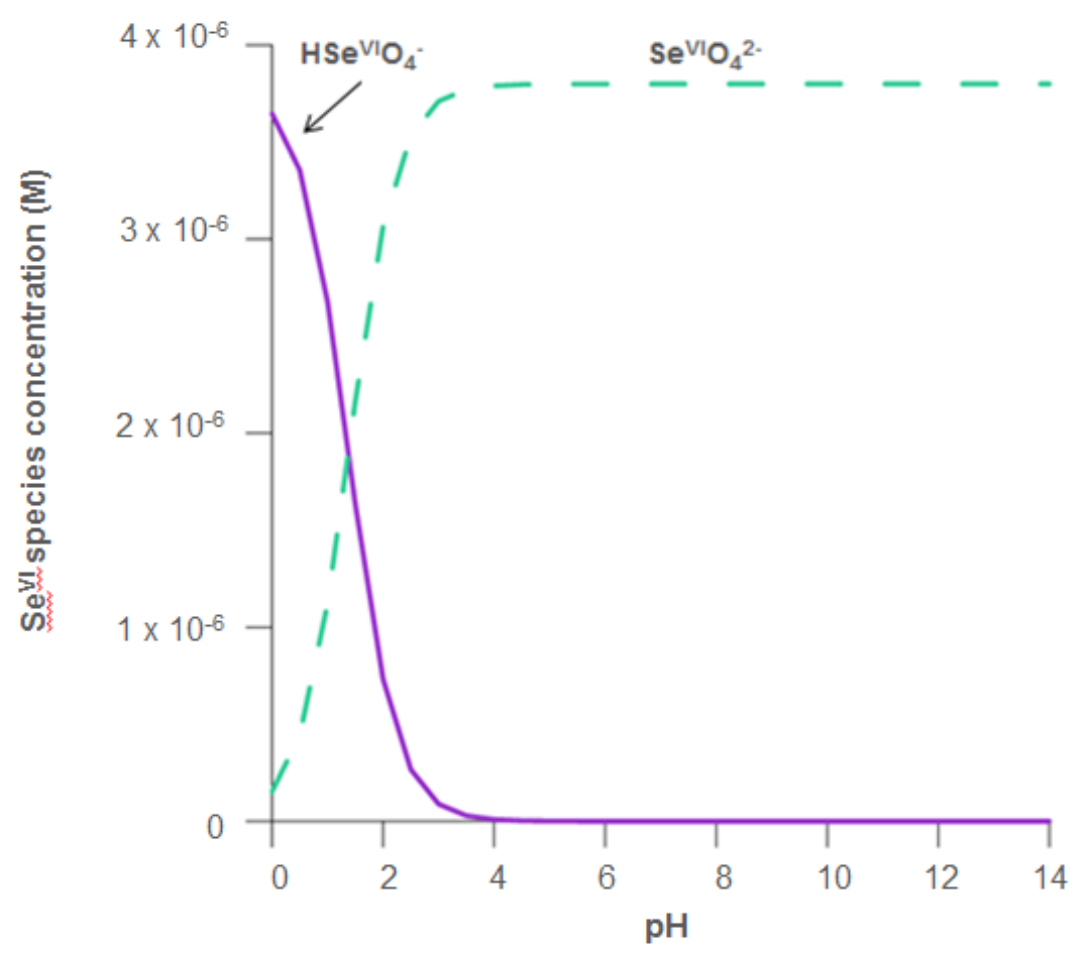

Figure 2-3. Selenate ion speciation plot, where $\mathrm{Se}^{\mathrm{VI}}$ concentration equals $3.80 \times 10^{-6} \mathrm{M}$ $(300 \mu \mathrm{g} / \mathrm{L})$, temperature equals $25^{\circ} \mathrm{C}$, and ionic strength equals $0.1 \mathrm{M}$. Figure constructed using Visual MINTEQ, version 3.1 (Allison et al., 1991). 

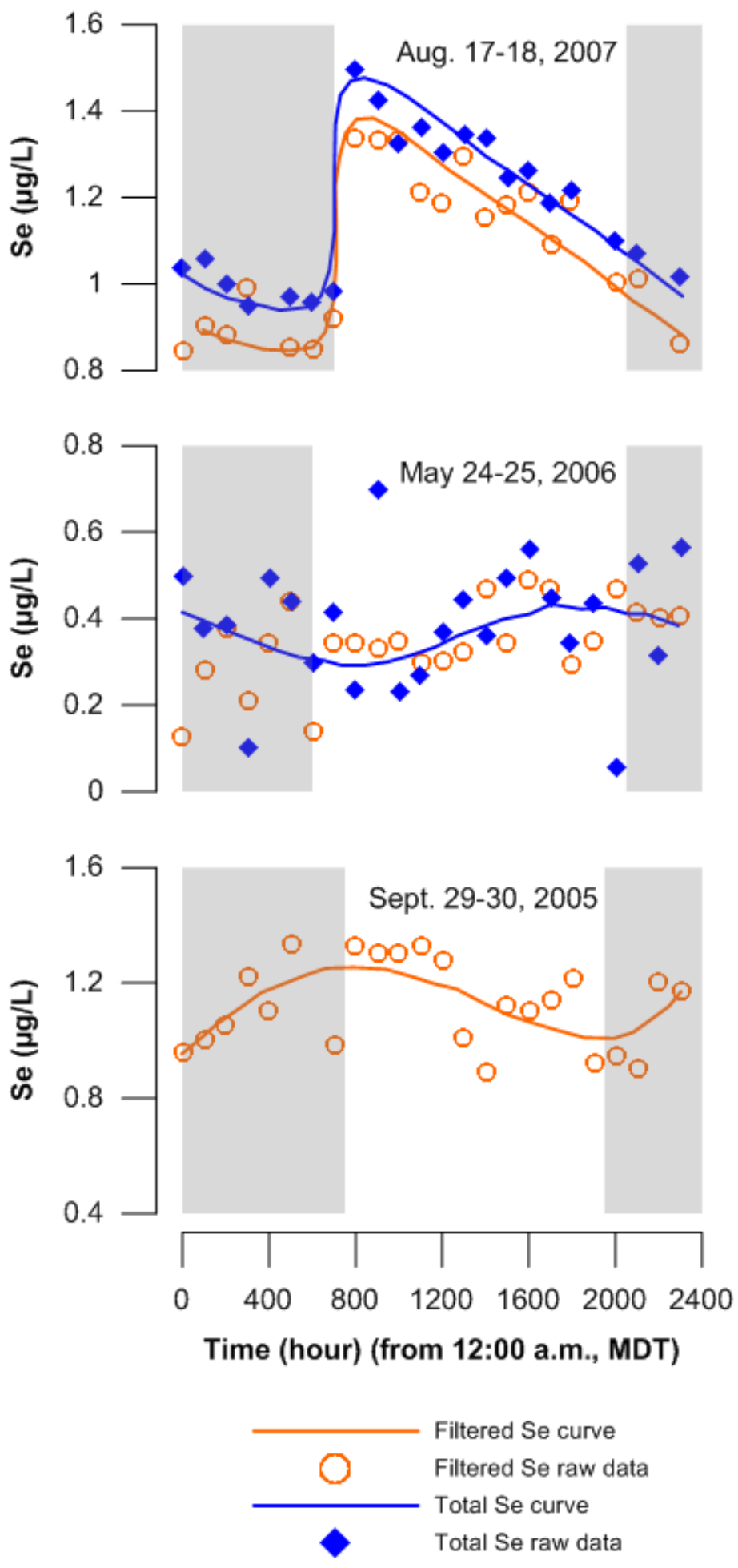

Figure 2-4. Summary of Dicataldo et al. (2011) results for Se diel cycles in a freshwater wetland of the Great Salt Lake, Utah. The gray shaded areas indicate nightime hours (dark conditions). Figure modified from Dicataldo et al., 2011. 
0.1 to $0.7 \mu \mathrm{g} / \mathrm{L}$. Dicataldo et al.'s August 2007 sampling event resulted in maximum filtered Se(total) and unfiltered Se(total) concentrations at sunrise and decreasing concentrations throughout the remainder of the day and night, ranging from 0.7 to $1.5 \mu \mathrm{g} / \mathrm{L}$. They found that Se(total) cycled in phase with $\mathrm{pH}$, dissolved oxygen, and water temperature. It was hypothesized that the variation in Se(total) concentrations could have occurred due to Se species sorption onto metal oxyhydroxides. The sorption and desorption of Se species was likely controlled by changes in $\mathrm{pH}$ and redox conditions caused by photosynthesis.

Carling et al. (2011) reported diel cycles of Se(total) in two freshwater wetlands of the Great Salt Lake (Figure 2-5). They hypothesized that filtered Se(total) concentrations cycled due to $\mathrm{pH}$-controlled sorption onto metal oxides during nighttime hours. The Se(total) concentrations increased during the day and decreased at night which was positively correlated with dissolved oxygen and temperature changes. In August 2008, Se(total) concentrations ranged from 1.2 to $1.7 \mu \mathrm{g} / \mathrm{L}$ in both wetlands. In September 2009, the Se(total) concentrations ranged from 0.7 to $1.0 \mu \mathrm{g} / \mathrm{Lin}$ both wetlands. Diel cycles of Se have not been reported outside the wetland studies of the Great Salt Lake, Utah.

Although Se cycles have not been studied extensively, diel cycles of arsenic (As), another element that forms oxyanions in water, have been reported. Nimick et al. (1998) reported pHcontrolled diel cycles of filtered As(total) (dissolved or particulate $<0.1 \mu \mathrm{m}$ in diameter, including both $\mathrm{As}^{\mathrm{III}}$ and $\mathrm{As}^{\mathrm{V}}$ species) at three of five sampling sites along the Madison and Missouri Rivers. Concentrations of As(total) increased as $\mathrm{pH}$ values increased, and decreased with decreasing $\mathrm{pH}$. The As(total) concentrations cycled in the opposite phase of the cations in this study. The $\mathrm{pH}$ at their sampling sites ranged from 7.2 to 9.0, and speciation analysis indicated that $\mathrm{As}^{\mathrm{V}}$ was the dominant species. The researchers concluded that As diel cycles were controlled by $\mathrm{pH}$-dependent sorption onto hydroxide coatings and desorption from hydroxide coatings in river bed sediments. Additionally, for their sites that did not display an As diel cycle, they concluded the $\mathrm{pH}$ values were not high enough for cycling to occur. As $\mathrm{pH}$ decreases, the sorption of As oxyanions, such as arsenite $\left(\mathrm{As}^{\mathrm{III}} \mathrm{O}_{3}{ }^{3-}\right)$ and arsenate $\left(\mathrm{As}^{\mathrm{V}} \mathrm{O}_{4}{ }^{3-}\right)$, onto hydroxide coatings is more likely. Fuller and Davis (1989) and Nimick et al. (2005) also found that filtered As(total) concentrations cycled in phase with $\mathrm{pH}$. The As cycle patterns during those studies were similar to those reported by Nimick et al. (1998). 

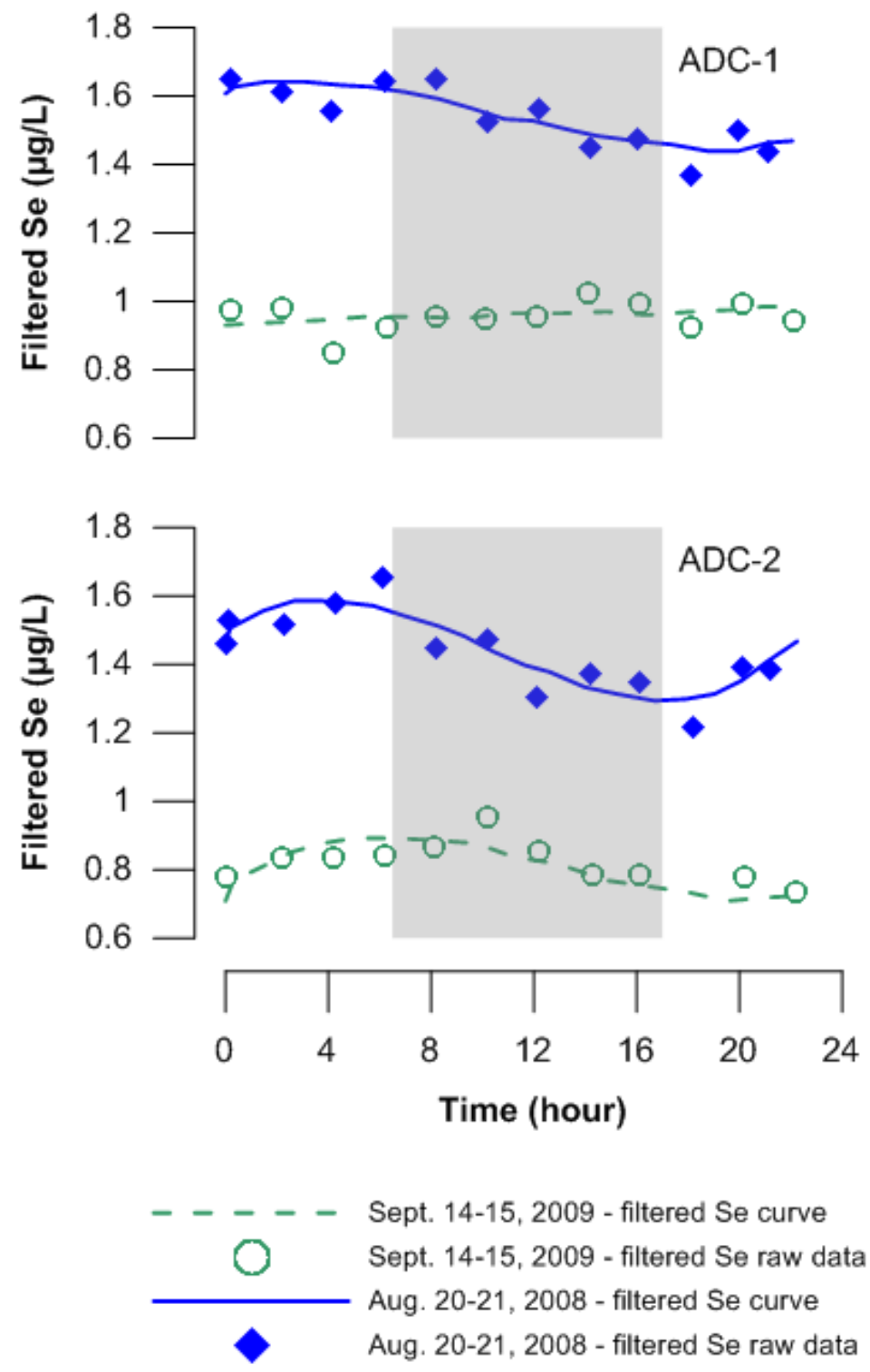

Figure 2-5. Summary of Carling et al. (2011) results for Se diel cycles in two freshwater wetlands (ADC-1 and ADC-2) of the Great Salt Lake, Utah. The gray shaded areas indicate nightime hours (dark conditions). Figure modified from Carling et al., 2011. 


\subsection{Se sorption onto ferrihydrite}

Ferrihydrite $\left(\mathrm{Fe}(\mathrm{OH})_{3}\right)$ is a Fe ${ }^{\mathrm{III}}$ hydroxide mineral with a large surface area $\left(>200 \mathrm{~m}^{2} \mathrm{~g}^{-1}\right)$ and a high affinity for sorption of $\mathrm{Se}^{\mathrm{IV}}$ (Parida et al., 1997; Zhao et al., 1994). $\mathrm{Se}^{\mathrm{IV}}$ is known to sorb more strongly to $\mathrm{Fe}$ oxide and oxyhydroxide surfaces than $\mathrm{Se}^{\mathrm{VI}}$, and sorption studies have concluded that ferrihydrite is the best Fe oxide/hydroxide for Se sorption under oxic and acidic conditions (Das et al., 2013). $\mathrm{Se}^{\mathrm{IV}}$ sorption onto ferrihydrite is known to increase with decreasing temperature and $\mathrm{pH}$ (Balistrieri and Chao, 1990; Parida et al., 1997). Parida et al. (1997) also found that $\mathrm{Se}^{\mathrm{IV}}$ sorption onto ferrihydrite reached equilibrium within two hours under various $\mathrm{pH}$ (3.5 to 9.5) and temperature conditions. They also concluded that the surface of ferrihydrite is heterogeneous based on calculated distribution coefficient $\left(\mathrm{K}_{\mathrm{D}}\right)$ values from sorption experiments. At a pH of 3, the $\mathrm{K}_{\mathrm{D}}$ increased as the $\mathrm{Se}^{\mathrm{IV}}$ (adsorbent) concentration increased. Sorption of $\mathrm{Se}^{\mathrm{IV}}$ can occur via the formation of two types of surface complexes: $\equiv \mathrm{SeO}_{3}{ }^{-}$and $\equiv \mathrm{HSeO}_{3}$, where $\equiv$ represents the surface. The first is the formation of $\equiv \mathrm{OH}_{2}{ }^{+}-\mathrm{SeO}_{3}{ }^{2-}$ and $\equiv \mathrm{OH}_{2}{ }^{+}$ - $\mathrm{HSeO}_{3}{ }^{-}$outer sphere complexes, which are produced by the electrostatic attraction between the $\mathrm{Se}^{\mathrm{IV}}$ aqueous species and surface hydroxyl groups. The second type of surface complex is an inner sphere complex resulting from the replacement of a water molecule with a $\mathrm{Se}^{\mathrm{IV}}$ aqueous species on an active surface site resulting in $\equiv \mathrm{SeO}_{3}{ }^{-}$or $\equiv \mathrm{HSeO}_{3}{ }^{0}$. $\mathrm{Se}^{\mathrm{IV}}$ can also adsorb to ferrihydrite at $\mathrm{pH}$ values greater than the zero point of charge $\left(\mathrm{pH}_{\mathrm{PZC}}\right)$, which is possible when $\mathrm{Se}^{\mathrm{IV}}$ and ferrihydrite interactions are able to exceed electrostatic forces (Parida et al., 1997). $\mathrm{Se}^{\mathrm{VI}}$ is known to sorb onto ferrihydrite as both monodentate and bidentate inner-sphere complexes (Das et al., 2013). Manceau and Charlet (1994) found that $\mathrm{Se}^{\mathrm{VI}}$ sorbs to ferrihydrite via an innersphere binuclear complex in $\mathrm{pH}$ ranges of 3.5 to 6.7 whereas $\mathrm{Se}^{\mathrm{IV}}$ sorbs via an inner-sphere bidentate complex at a $\mathrm{pH}$ of 3. Many factors may affect the sorption of Se species onto ferrihydrite, including solution ionic strength, $\mathrm{pH}$, temperature, surface loading, Se species present, and timing (Sparks, 2003).

The conditional enthalpy for trace metal adsorption onto hydrous ferric oxides (HFO) can be calculated when temperatures and dissolved trace metal concentrations are known over time. Conditional enthalpies of adsorption $\left(\Delta \mathrm{H}_{\mathrm{ads}}\right)$ can be calculated using the following equation (Gammons et al., 2005b): 


$$
\Delta H_{a d s}=\frac{2.303 R \log \left(\frac{C_{2}}{C_{1}}\right)}{\left(\frac{1}{T_{2}}-\frac{1}{T_{1}}\right)}
$$

where $\mathrm{R}$ is the ideal gas constant, $\mathrm{C}_{1}$ and $\mathrm{C}_{2}$ are the dissolved trace metal molar concentrations at temperatures $\mathrm{T}_{1}$ and $\mathrm{T}_{2}$ (Kelvin). For a set of concentration and temperature data, the $\Delta \mathrm{H}_{\mathrm{ads}}$ can be calculated by plotting $1 / \mathrm{T}$ versus $\log \mathrm{C}$, where $\mathrm{T}$ is temperature in Kelvin and $\mathrm{C}$ is the dissolved trace metal concentration. The slope of the line is then multiplied by $2.303 \mathrm{R}$ to get the $\Delta \mathrm{H}_{\mathrm{ads}}$ value (Gammons et al., 2005b):

$$
\log C=\frac{\Delta H_{a d s}}{2.303 R}\left(\frac{1}{T}\right)+b
$$

This calculation assumes that a single trace metal is present in solution at a constant concentration, the sorbent concentration remains constant, and changes in dissolved trace metal concentrations are only due to adsorption/desorption with temperature. Machesky (1990) used a chemical modeling approach to calculate enthalpy of sorption values of $\mathrm{Se}^{\mathrm{IV}}$ (specifically, the $\mathrm{HSeO}_{3}{ }^{-}$species) onto goethite. The resulting $\Delta \mathrm{H}_{\mathrm{ads}}$ values ranged from $-82 \mathrm{~kJ} / \mathrm{mol}$ to $-22 \mathrm{~kJ} / \mathrm{mol}$. $\Delta \mathrm{H}_{\text {ads }}$ values for $\mathrm{Se}^{\mathrm{IV}}$ sorption onto HFO have not been reported in natural waters.

Many trace metals are present as cations in natural waters, and exhibit different sorption behavior than Se which forms an oxyanion. Laboratory studies suggest that adsorption of trace metal anions increases with decreasing temperature (Nimick et al., 2003); therefore, resulting in negative $\Delta \mathrm{H}_{\mathrm{ads}}$ values. Nimick et al. (2003) found that As adsorption increases with decreasing temperature. Since As forms oxyanions in water, it is likely that Se sorption will reflect similar sorption behavior in response to temperature changes.

\subsection{Ferrihydrite solubility}

$\mathrm{Fe}^{\mathrm{III}}$ oxyhydroxides have extremely low solubility (Schwertmann, 1991). The solubility product $\left(\mathrm{K}_{\mathrm{sp}}\right)$ of ferrihydrite, $\mathrm{Fe}(\mathrm{OH})_{3}$, is $1 \times 10^{-37}$ (Benjamin, 2002). At $\mathrm{pH}$ values less than four, $\mathrm{Fe}^{\mathrm{III}}, \mathrm{Fe}(\mathrm{OH})^{2+}$, and $\mathrm{Fe}(\mathrm{OH})_{2}{ }^{+}$are the dominant $\mathrm{Fe}$ species associated with the dissolution of ferrihydrite. Changes in temperature, $\mathrm{pH}$, and oxidation-reduction potential may affect the 
solubility of ferrihydrite (Figures 2-6 and 2-7). Ferrihydrite is likely to precipitate with increasing temperature and $\mathrm{pH}$ values around eight (Schwertmann and Cornell, 2007). Ferrihydrite solubility can also be affected by the presence of other ions in solution, such as chloride or sulfate. These ions may form surface complexes with hydrogen on the mineral surface and increase ferrihydrite solubility by weakening Fe-O bonds (Schwertmann, 1991). When submerged in water at low $\mathrm{pH}$ values, ferrihydrite can alter to hematite or goethite (Schwertmann and Cornell, 2007), which have a lower solubility and sorption capacity than ferrihydrite (Schwertmann, 1991).

\subsection{Fe diel cycles}

\subsubsection{Light cycles}

Photoreduction of ferric $\mathrm{Fe}\left(\mathrm{Fe}^{\mathrm{III}}\right)$ to ferrous Fe $\left(\mathrm{Fe}^{\mathrm{II}}\right)$ occurs in the ultraviolet (UV) spectrum in a wavelength range from 360 to $450 \mathrm{~nm}$ and at an optimal pH range from 2 to 4 (Gammons et al., 2008; King et al.1993; McKnight et al., 2001). In this pH range, in the presence of sunlight, the dissolution of HFO is favorable, and has been linked to increases in $\mathrm{Fe}^{\mathrm{II}}$ and total dissolved $\mathrm{Fe}$ (Fe(total); including both dissolved $\mathrm{Fe}^{\mathrm{II}}$ and $\mathrm{Fe}^{\mathrm{III}}$ species) (Nimick et al., 2003). Fe ${ }^{\mathrm{III}}$ photoreduction may occur via two chemical pathways as described by Kimball et al. (1992) in the equations below:

$$
\begin{array}{ll}
\mathrm{Fe}^{\mathrm{III}}(\mathrm{OH})^{2+}+h v \rightarrow \mathrm{Fe}^{\mathrm{II}}+{ }^{\circ} \mathrm{OH} & \text { [Eq. 6] } \\
\mathrm{Fe}^{\mathrm{III}}: \mathrm{OH}^{-}+h v \rightarrow \equiv \mathrm{Fe}^{\mathrm{II}}+{ }^{\circ} \mathrm{OH} & {[\text { Eq. 7a] }} \\
\equiv \mathrm{Fe}^{\mathrm{III}} \rightarrow \mathrm{Fe}^{\mathrm{II}} & \text { [Eq. 7b] }
\end{array}
$$

Where ${ }^{\circ} \mathrm{OH}$ is a hydroxyl radical, $h v$ the photon, and $\equiv \mathrm{Fe}^{\mathrm{II}}$ is a surface bound species. Equation 6 represents a homogeneous aqueous phase. The main aqueous species responsible for $\mathrm{Fe}^{\mathrm{III}}$ photoreduction is $\mathrm{Fe}(\mathrm{OH})^{2+}$, which is typically the most abundant $\mathrm{Fe}^{\mathrm{III}}$ species present at $\mathrm{pH}$ values between 2 and 4 (Kimball et al., 1992; King et al., 1993). Equations 7a and 7b represent a heterogeneous surface phase where a surface bound $\mathrm{Fe}^{\mathrm{III}}$ species is reduced and then released. This process may occur at the surface of $\mathrm{Fe}^{\mathrm{III}}$ oxyhydroxides (e.g. ferrihydrite). 


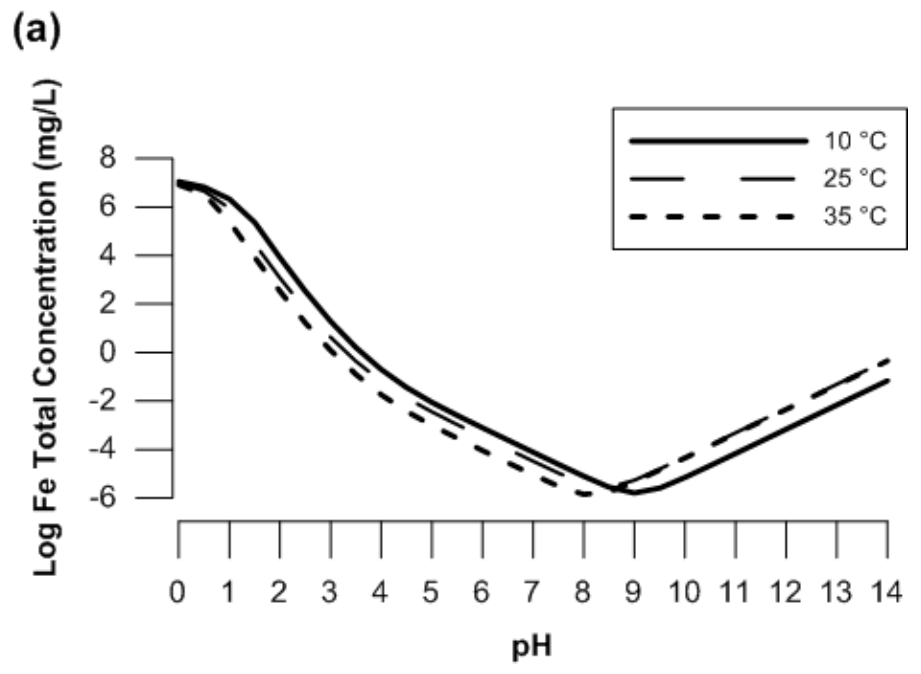

(b)
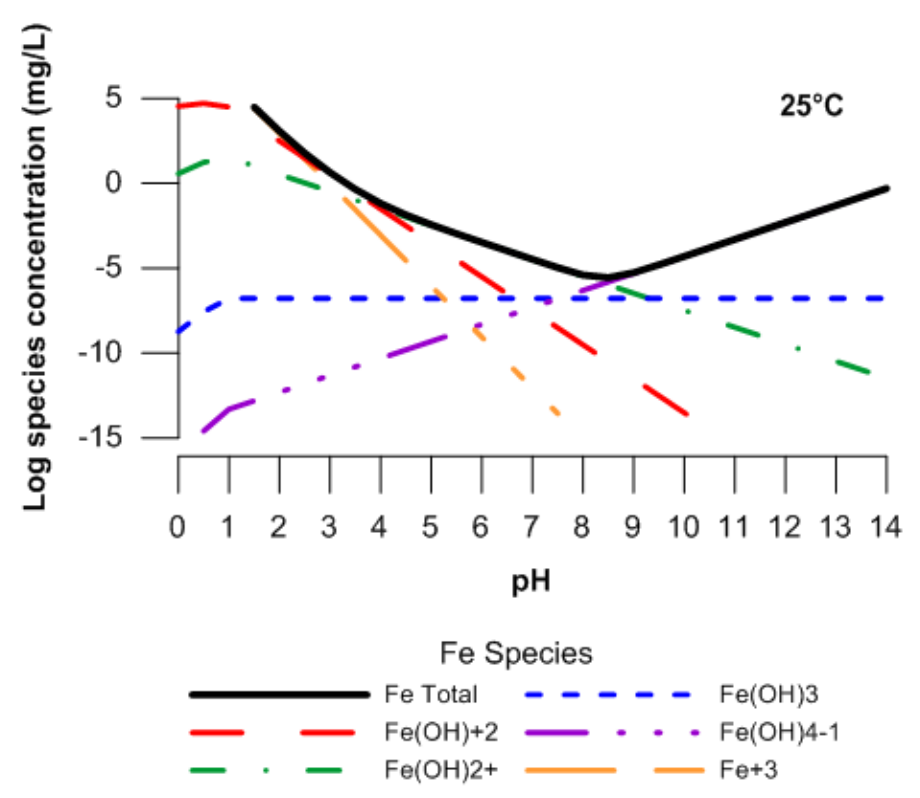

Figure 2-6. (a) Solubility curves for $0.5 \mathrm{~g}$ of ferrihydrite, $\mathrm{Fe}(\mathrm{OH})_{3}$, at $10{ }^{\circ} \mathrm{C}, 25^{\circ} \mathrm{C}$, and $35^{\circ} \mathrm{C}$ showing Fe(total) concentrations and (b) Solubility diagram for $0.5 \mathrm{~g}$ of ferrihydrite at $25^{\circ} \mathrm{C}$ showing all $\mathrm{Fe}$ species, where ionic strength equals $0.1 \mathrm{M}$. Figure constructed using Visual MINTEQ, version 3.1 (Allison et al., 1991). 


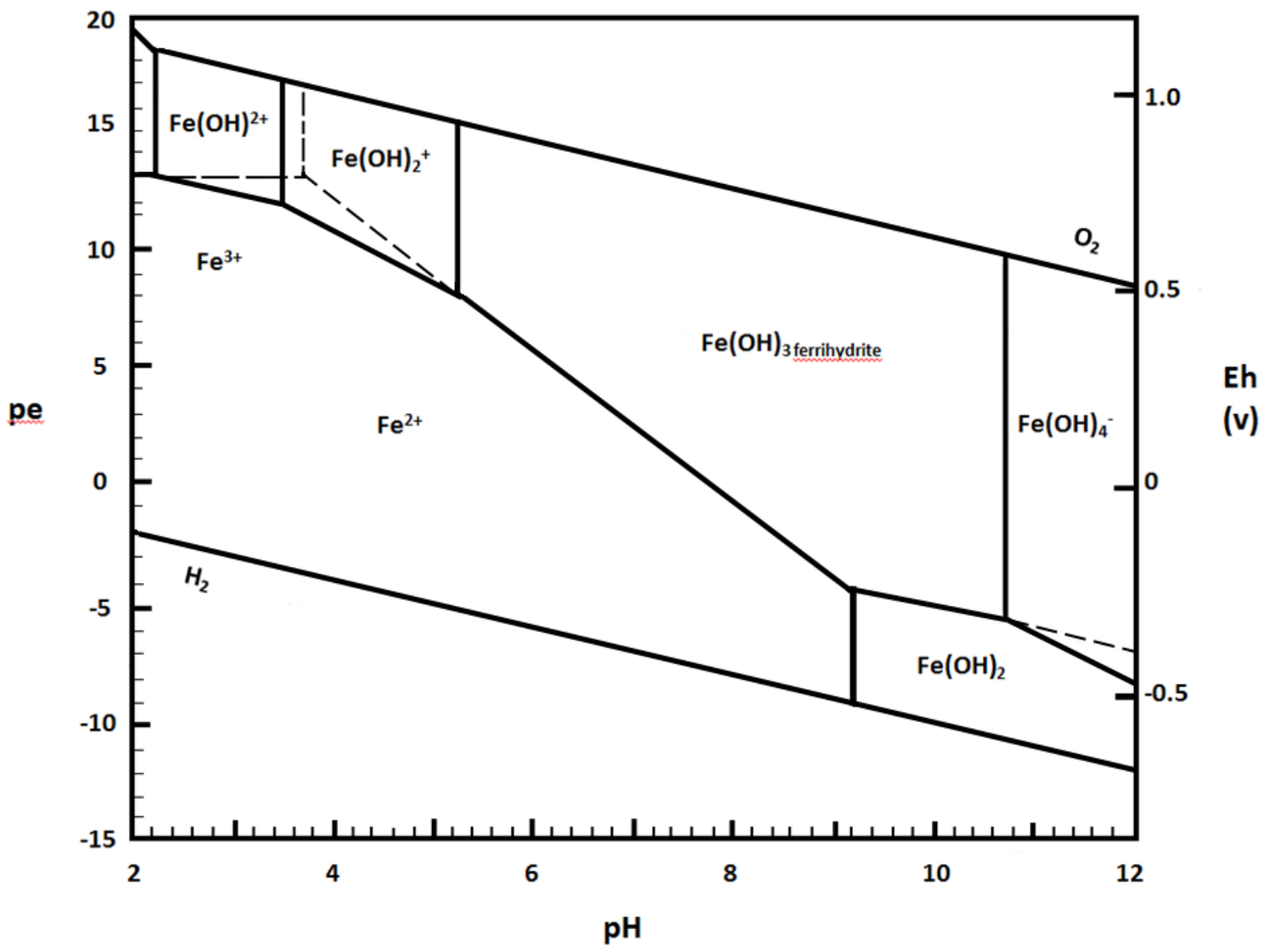

Figure 2-7. Redox potential-pH diagram for the Fe-O-H2O system for a dissolved Fe species concentration of $10^{-6} \mathrm{M}$ at $1 \mathrm{~atm}$ and $25^{\circ} \mathrm{C}$. Figure modified from Drever, 1997. 


\subsubsection{Temperature cycles}

In nature, it is difficult to delineate the difference between the effects of temperature, $\mathrm{pH}$, and solar input on Fe concentrations (Nimick, 2003). Temperature often cycles in phase with light intensity (i.e. temperature increases during the day and decreases at night). Temperature also creates a kinetic effect for Fe cycles by increasing Fe oxidation rates in warmer water (Wakao and Shiota, 1982). Parker et al. (2007) and Gammons et al. (2005a) found that $(\mathrm{Fe}($ total $))$ and $\mathrm{Fe}^{\mathrm{II}}$ both decreased with lower temperatures at night, and increased with higher temperatures during daytime hours. However, they determined that Fe cycles were likely influenced more by Fe ${ }^{\mathrm{III}}$ photoreduction by solar input. They also concluded that as temperature increases, the solubility of HFO decreases, which could contribute to the change in Fe(total) concentrations. 


\section{PURPOSE AND OBJECTIVES}

The purpose of this research was to test in a laboratory setting if $\mathrm{Se}^{\mathrm{IV}}$ cycles exist in the presence of Fe cycles. The hypothesis was that $\mathrm{Se}^{\mathrm{IV}}$ (including the protonated and deprotonated species) will cycle in phase with $\mathrm{Fe}$ due to $\mathrm{Se}^{\mathrm{IV}}$ species sorption onto 2-line ferrihydrite (i.e. as $\mathrm{Fe}$ moves from the solid to the dissolved phase it will release the existing sorbed $\mathrm{Se}^{\mathrm{IV}}$ species). $\mathrm{Se}^{\mathrm{IV}}$ was chosen over $\mathrm{Se}^{\mathrm{VI}}$, because it has a greater affinity for sorption onto ferrihydrite. The oxidation of $\mathrm{Se}^{\mathrm{IV}}$ to $\mathrm{Se}^{\mathrm{VI}}$ is also kinetically slow; therefore, reducing the possibility of Se species conversion. The specific objectives of this project are outlined below.

- Objective 1: Generate Fe-only cycles (both $\mathrm{Fe}^{\mathrm{II}}$ and $\mathrm{Fe}^{\mathrm{III}}$ cycles) via temperature and light control experiments.

- Objective 2: Generate Se-only cycles via temperature and light control experiments.

- Objective 3: Generate combined Fe-Se cycles using temperature and light control experiments.

- Objective 4: Evaluate the relative effectiveness of temperature and light on creating Fe and $\mathrm{Se}^{\mathrm{IV}}$ cycles. 


\section{METHODS}

\subsection{Experimental overview and layout}

The experiments were conducted using temperature and light as a potential drivers of $\mathrm{Fe}$ and Se cycles. A flow system was constructed to regulate temperature in four 1-liter waterjacketed vessels where the experiments were carried out (Figures 4-1 and 4-2). Three different controls were used to regulate water temperature of this system: ice water (ideally $0^{\circ} \mathrm{C}$ ), room temperature (RT) water $\left(21-23^{\circ} \mathrm{C}\right.$ ), and hot water (set to $35^{\circ} \mathrm{C}$ ). Valves that connect the temperature baths to a mixing chamber were adjusted to achieve the desired temperature. Each temperature controlled cycle followed this general trend: started at room temperature, heated up slowly $\left(35^{\circ} \mathrm{C}\right.$ maximum), cooled down slowly to room temperature, continued to cool down slowly using ice water $\left(3^{\circ} \mathrm{C}\right.$ minimum), and finally heated back up to room temperature. All temperature control experiments were conducted in either light on or light off (dark) conditions.

Two standard full spectrum fluorescent bulbs (1.07 meters long) with a reflector were located 7.6 centimeters above the top of four water-jacketed vessels. The light was hung from a shelf, and its vertical position above the vessels was fixed by chains connected to the reflector (Figures 4-2 and 4-3). The full spectrum bulbs covered a wavelength range from $400 \mathrm{~nm}$ to 700 $\mathrm{nm}$, which includes the optimum wavelength for photoreduction of $\mathrm{Fe}^{\mathrm{III}}$ (Emmenegger et al., 2001). For each temperature control experiment, the light was either turned on or off throughout the duration of the experiment. For light control experiments, the light was turned on and off at specific intervals throughout the experiments. Temperature was not controlled during the light control experiments (the reaction vessel water jackets were filled with room temperature water). During dark cycles (light off), red light-emitting diode (LED) strip lights were used as a light alternative for vision purposes. Red LED lights were chosen, because they emit wavelengths less than the wavelength range needed for $\mathrm{Fe}^{\mathrm{III}}$ photoreduction. 


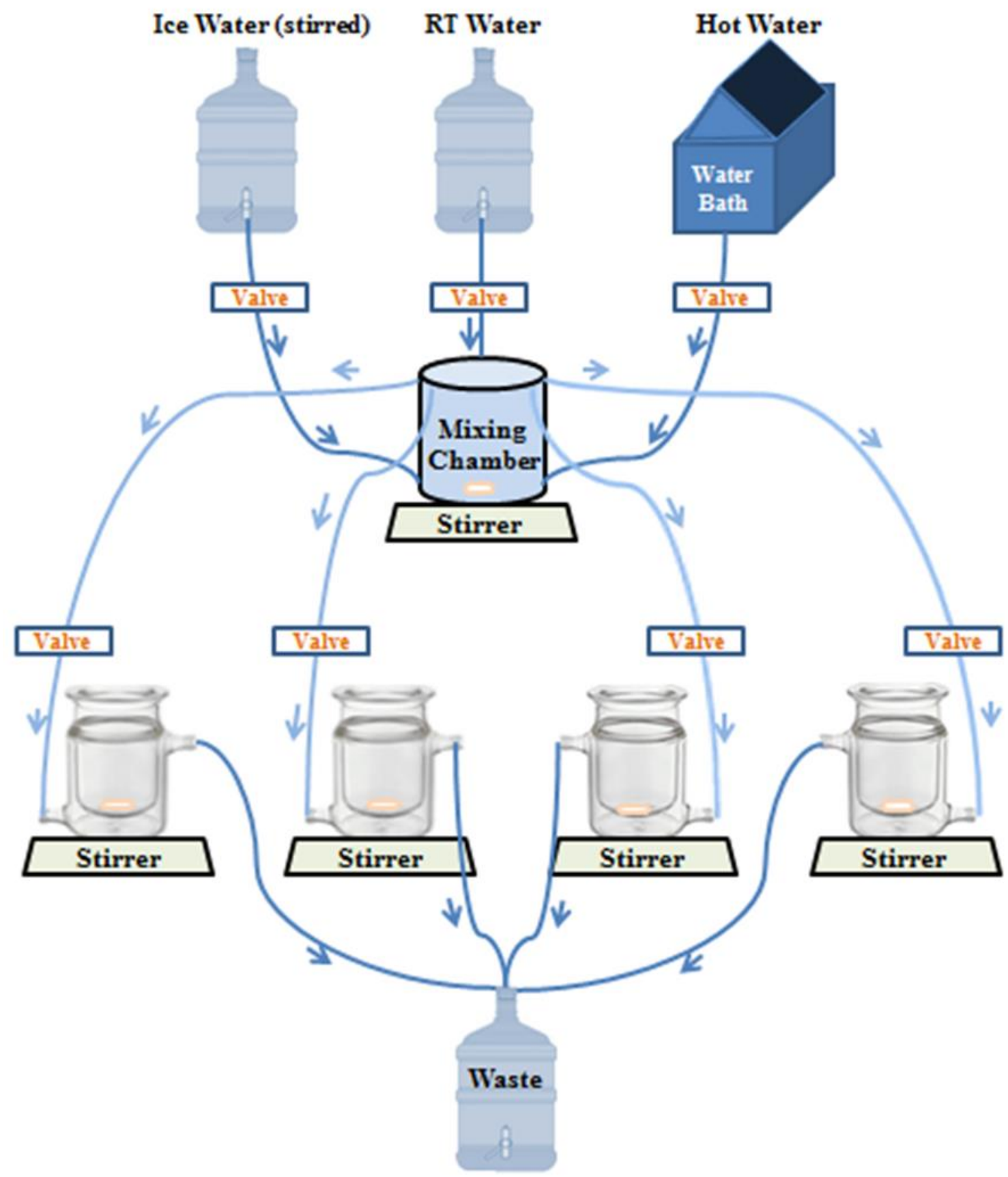

Figure 4-1. Schematic of temperature control system. Arrows indicate water flow direction. 


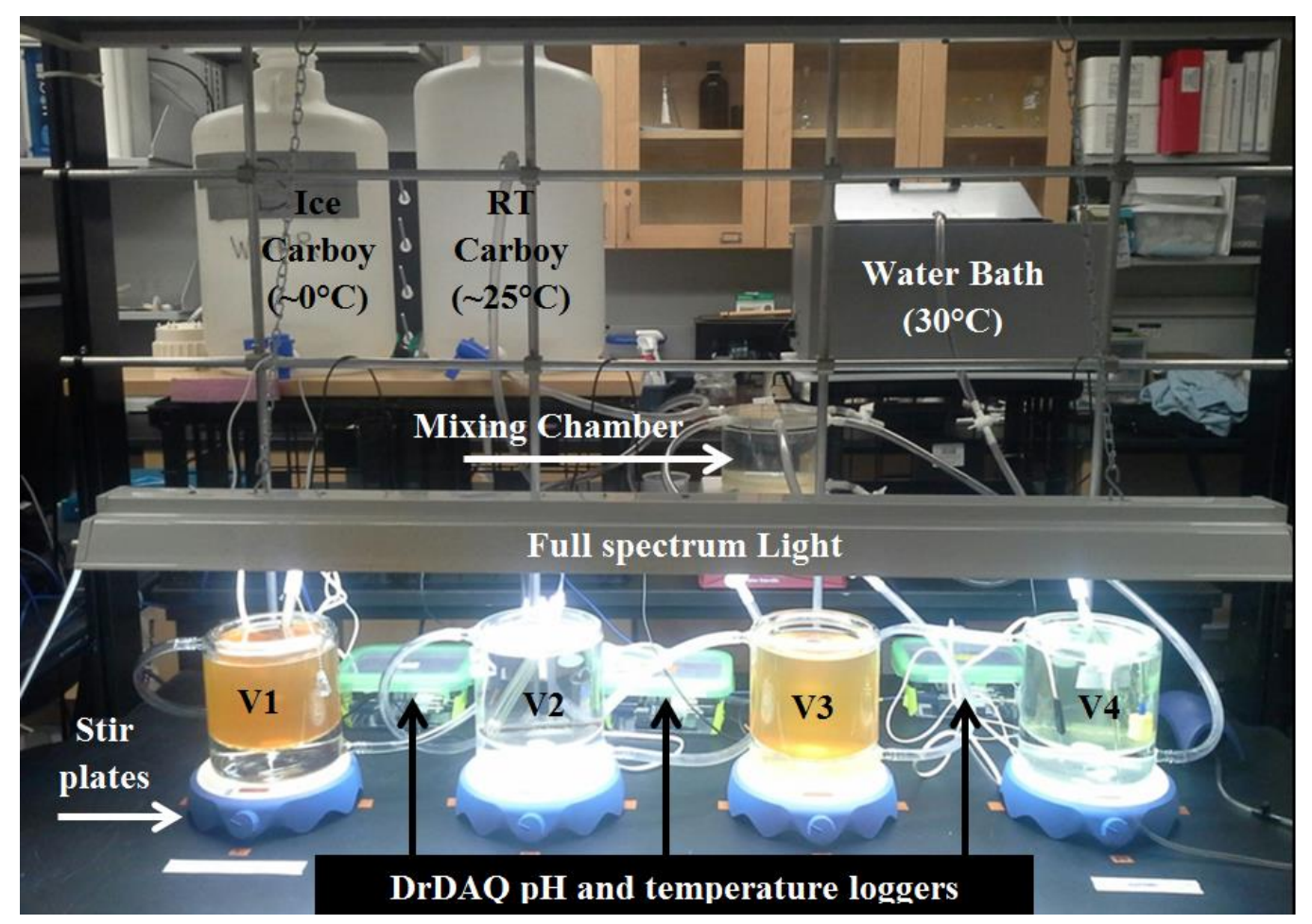

Figure 4-2. Photograph of completed temperature and light control systems. RT is room temperature. V1, V2, V3, and V4 are the vessel numbers. 
Shelf

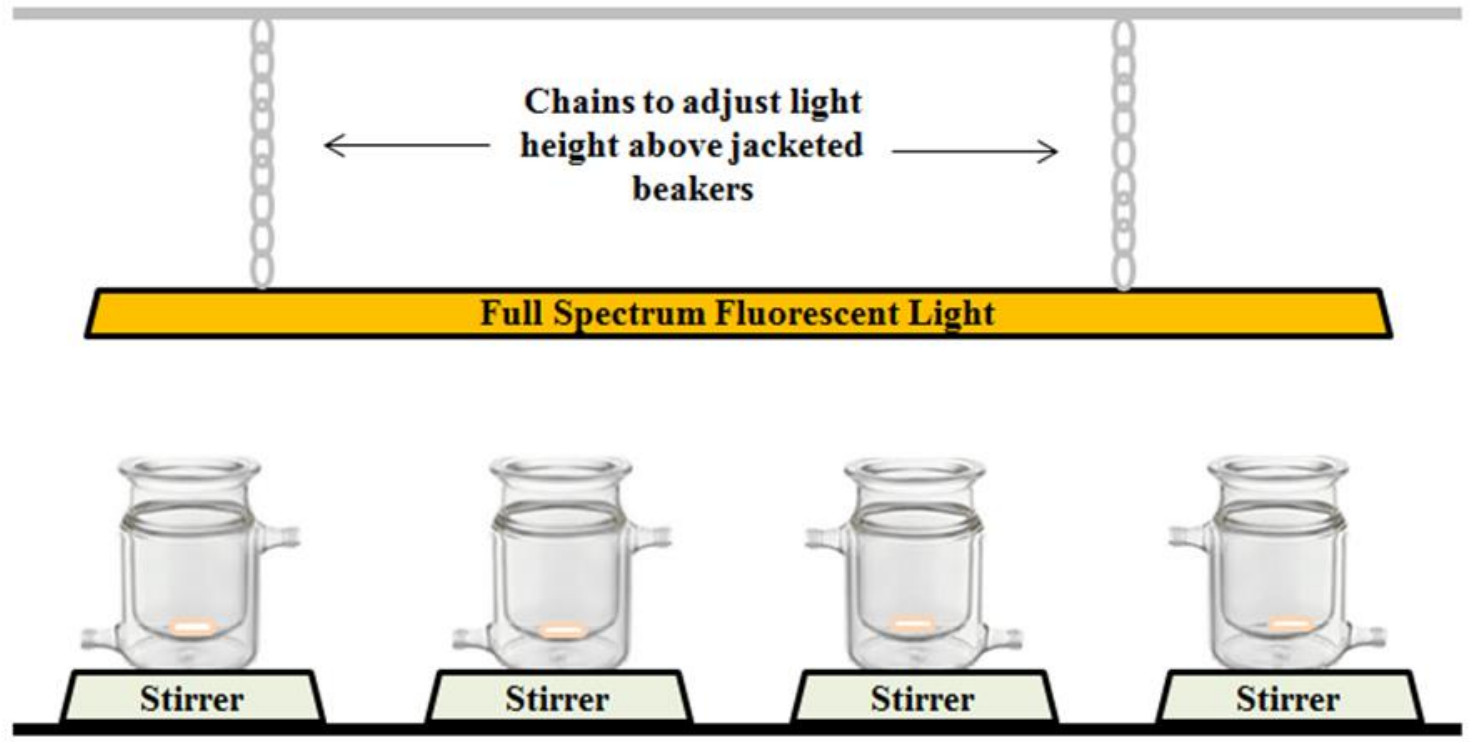

Figure 4-3. Schematic of light control system. 


\subsection{Materials}

\subsubsection{2-line Ferrihydrite}

2-line ferrihydrite (a Fe oxyhydroxide mineral with two distinct x-ray diffraction (XRD) peaks) having an approximate chemical formula of $5 \mathrm{FeOOH} \cdot 2 \mathrm{H}_{2} \mathrm{O}$ (Lee et al., 2014; Zhao et al., 1994), was synthesized using the method described by Schwertmann and Cornell (2007) with a few minor adjustments. First, Dry Spectra/Por® dialysis membrane tubing (Spectrum Laboratories, Inc., TX, USA) was soaked in deionized water (DI) water for 30 minutes. 40 grams of ferric nitrate nonahydrate $\left(\mathrm{Fe}\left(\mathrm{NO}_{3}\right)_{3} \cdot 9 \mathrm{H}_{2} \mathrm{O}\right)$ (Fisher Scientific, NJ, USA) was then added to $500 \mathrm{~mL}$ of DI water and was magnetically stirred until all of the solid dissolved. Approximately $300 \mathrm{~mL}$ of $1 \mathrm{~N}$ potassium hydroxide (KOH) (Fisher Scientific, NJ, USA) was then added to bring the solution $\mathrm{pH}$ between 7 and 8 . The solution was stirred vigorously for several minutes and was then poured into $60 \mathrm{~mL}$ syringes. The syringes were stored tip down for 30 minutes until the solid settled. The solid was syringed into the dialysis membrane tubing and was soaked in DI water for 72 hours. The DI water was replaced periodically over the 72-hour period to maximize the removal of $\mathrm{K}^{+}$and $\mathrm{NO}_{3}{ }_{3}$ ions from the solid 2-line ferrihydrite slurry. After the soaking period, the 2-line ferrihydrite was poured into crucibles and set in a laboratory hood for four days to air dry. Once dry, the 2-line ferrihydrite was ground into a fine powder using a mortar and pestle and sieved through a $125 \mu \mathrm{m}$ sieve to obtain a consistent solid particle size. The solid was then stored in a glass container until use (Figure 4-4).

It was important to closely monitor the $\mathrm{pH}$ of the Fe solution once the $\mathrm{KOH}$ was added. If the solution exceeded a $\mathrm{pH}$ value between 8 and 9 , it was likely for goethite or hematite to precipitate instead of 2-line ferrihydrite. To ensure that the proper chemical composition for 2line ferrihydrite was achieved, a sample was sent for XRD analysis. The results confirmed that 2line ferrihydrite was synthesized (Appendix A). 
(a)

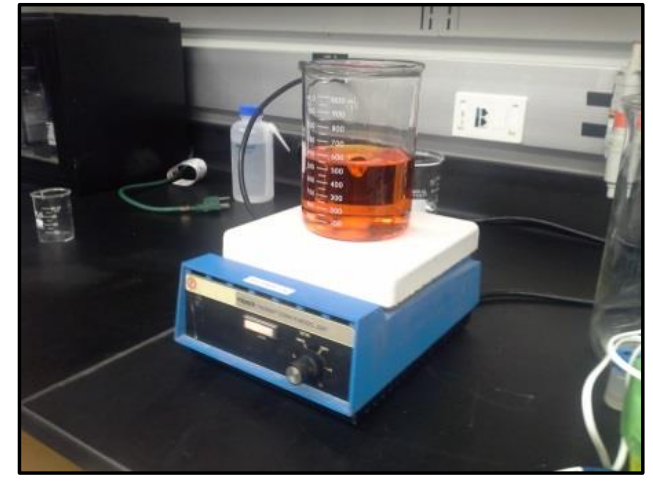

(c)

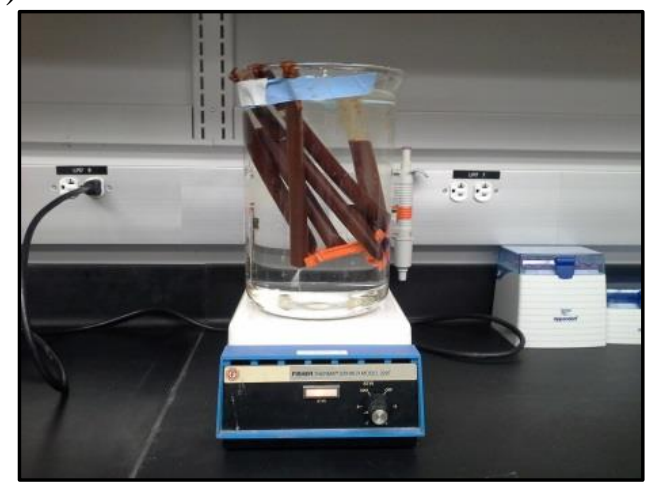

(e.)

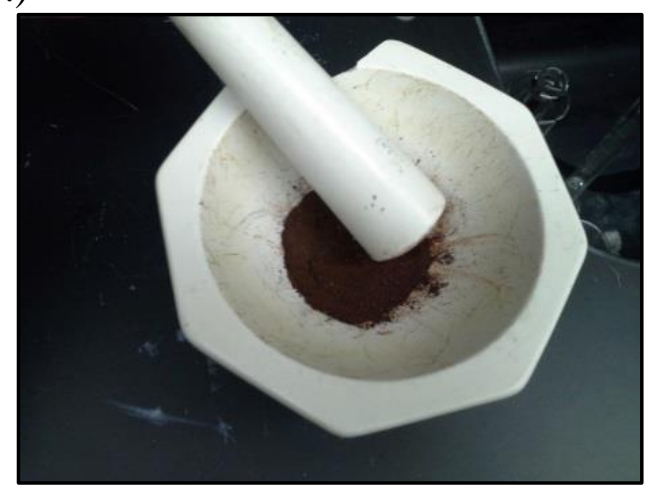

(b)

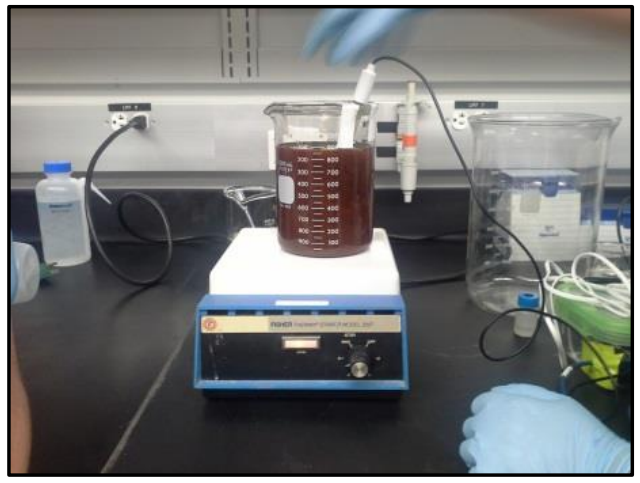

(d.)

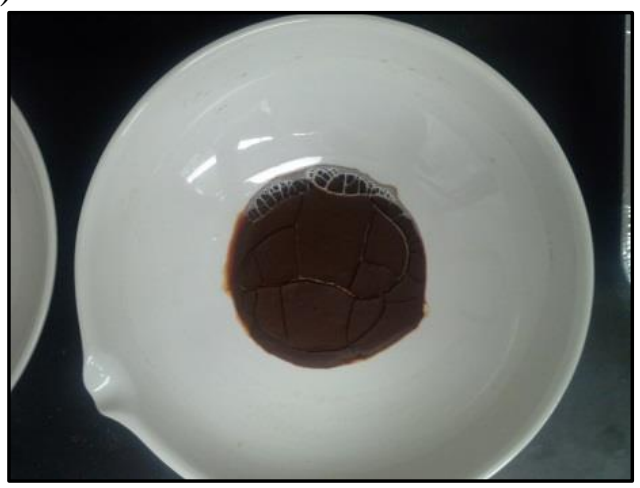

(f.)

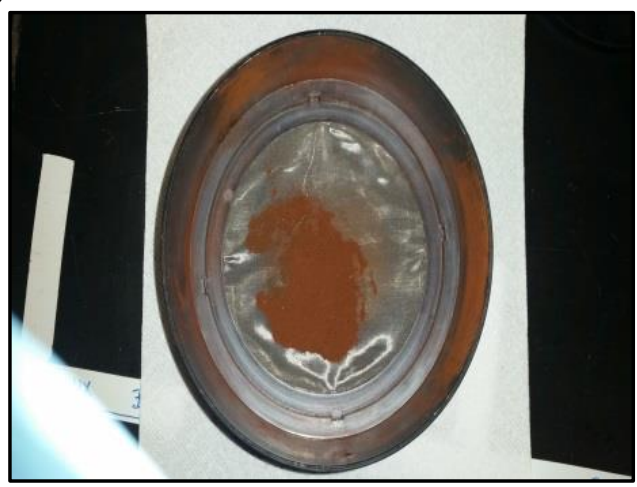

Figure 4-4. Synthesis of 2-line ferrihydrite. (a) 40 grams $\mathrm{Fe}\left(\mathrm{NO}_{3}\right)_{3} \cdot 9 \mathrm{H}_{2} \mathrm{O}$ dissolved in $500 \mathrm{~mL}$ DI water; (b) $300 \mathrm{~mL} \mathrm{KOH}$ added to solution; (c) Solid solution soaking in dialysis membrane tubing; (d) Solid drying in crucible; (e) Dried 2-line ferrihydrite crushed with mortar and pestle; and (f) 2-line ferrihydrite sieved through a $125 \mu \mathrm{m}$ sieve. 


\subsubsection{Solutions}

All solutions were prepared in 1-liter water jacketed vessels, and contained the following components (Table 4-1):

- 1 liter of DI water.

- Potassium chloride (KCl) (Fisher Scientific, NJ, USA) - $7.45 \mathrm{~g}$ added to each beaker to a concentration of $0.1 \mathrm{M}$ to fix the solution ionic strength. $\mathrm{KCl}$ was chosen, because $\mathrm{K}^{+}$ and $\mathrm{Cl}^{-}$are conservative ions and will not interfere with $\mathrm{Fe}$ or Se species in solution.

- Hydrochloric acid (HCl) (Fisher Scientific, NJ, USA) - the solution pH was adjusted to 3 using $10 \%(\mathrm{v} / \mathrm{v}) 12 \mathrm{~N} \mathrm{HCl}$.

- 2-line ferrihydrite - $500 \mathrm{mg}$ was added to introduce Fe into solution for Fe-only and FeSe combined experiments. The 2-line ferrihydrite solid did not dissolve completely.

- $\mathrm{Se}^{4+}$ CertiPrep Spex standard (NJ, USA) - $300 \mu \mathrm{L}$ of a $1000 \mathrm{mg} / \mathrm{L} \mathrm{Se}^{4+}$ CertiPrep Spex standard (containing 2\% (v/v) nitric acid) was added to Se-only and Fe-Se combined experiments to a final concentration of $300 \mu \mathrm{g} / \mathrm{L}(3.80 \mu \mathrm{M}) \mathrm{Se}^{\mathrm{IV}} .3000 \mu \mathrm{L}$ of the 1000 $\mathrm{mg} / \mathrm{L} \mathrm{Se}^{4+}$ CertiPrep Spex standard was added to one Fe-Se combined cycle experiment (Cycle 3) to a final concentration of $3000 \mu \mathrm{g} / \mathrm{L}(40.0 \mu \mathrm{M}) \mathrm{Se}^{\mathrm{IV}}$.

Each vessel was placed on a magnetic stir plate and stirred at $400 \mathrm{rpm}$. The vessels equilibrated for 48 hours until Fe(total) concentrations were stable, which was confirmed by 48 hour sorption experiments.

\subsection{Data logging and meter measurements}

DrDAQ $^{\circledR}$ temperature sensors and $\mathrm{HOBO}^{\circledR}$ Pendant light/temperature loggers (Table 4-2) were used to record temperature. DrDAQ ${ }^{\circledR}$ temperature sensors recorded in one second intervals and were displayed real-time during the experiments using PicoLog Recorder software. HOBO ${ }^{\circledR}$ Pendant light/temperature loggers were set to a five minute logging interval, and the data were retrieved after each experiment using HOBOWARE 2 software. Both instruments recorded temperature in degrees Celsius. 
Table 4-1. Experiment vessel solutions

\begin{tabular}{l|ccc}
\hline Solution component & $\begin{array}{c}\text { Fe-Only } \\
\text { Experiments }\end{array}$ & $\begin{array}{c}\text { Se-Only } \\
\text { Experiments }\end{array}$ & $\begin{array}{c}\text { Fe-Se combined } \\
\text { Experiments }\end{array}$ \\
\hline DI water (L) & 1 & 1 & 1 \\
KCl concentration (M) & 0.1 & 0.1 & 0.1 \\
$\mathrm{pH}$ (standard units) & 3 & 3 & 3 \\
2-line ferrihydrite (g) & 0.5 & --- & 0.5 \\
$\mathrm{Se}^{\mathrm{IV}}$ concentration $(\mu \mathrm{g} / \mathrm{L})$ & --- & 300 & 300 or 3000 \\
\hline
\end{tabular}

Note: DI is deionized water. All experiments contained $300 \mu \mathrm{g} / \mathrm{L} \mathrm{Se}{ }^{\mathrm{IV}}$, except for Cycle 3 which contained $3000 \mu \mathrm{g} / \mathrm{L} \mathrm{Se}^{\mathrm{IV}}$. 
Table 4-2. Measured parameters and instrumentation

\begin{tabular}{|c|c|c|c|c|}
\hline & Measured Parameters & Units & Instrumentation & Software \\
\hline \multirow{5}{*}{ 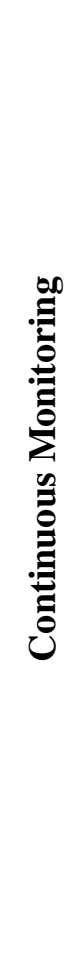 } & Temperature & ${ }^{\circ} \mathrm{C}$ & $\begin{array}{c}\mathrm{DrDAQ}^{\circledR} \mathrm{USB} \\
\text { temperature probes }\end{array}$ & PicoLog Recorder \\
\hline & Temperature & ${ }^{\circ} \mathrm{C}$ & $\begin{array}{c}\mathrm{HOBO}^{\circledR} \text { Pendant } \\
\text { light } / \text { temperature } \\
\text { loggers }\end{array}$ & HOBOWARE 2 \\
\hline & Light Intensity & Lux & $\begin{array}{c}\mathrm{HOBO}^{\circledR} \text { Pendant } \\
\text { light/temperature } \\
\text { loggers }\end{array}$ & HOBOWARE 2 \\
\hline & Light Intensity & $\mu \mathrm{Mol} / \mathrm{m}^{2} \mathrm{~s}$ & $\begin{array}{c}\text { AccuPAR Model LP- } \\
\text { 80 PAR/LAI } \\
\text { ceptometer }\end{array}$ & N/A \\
\hline & $\mathrm{pH}$ & $\begin{array}{l}\text { Standard } \\
\text { units }\end{array}$ & $\begin{array}{c}\operatorname{DrDAQ}^{\circledR} \mathrm{USB} \mathrm{pH} \\
\text { probes }\end{array}$ & PicoLog Recorder \\
\hline \multirow{2}{*}{$\underset{\substack{0 \\
0}}{\stackrel{0}{0}}$} & Dissolved Fe $\mathrm{F}^{\mathrm{II}}$ & $\mathrm{mg} \mathrm{L}^{-1}$ & $\begin{array}{c}\text { Hach }^{\circledR} \text { DR2800 } \\
\text { Spectrophotometer } \\
\left(\mathrm{MDL}=0.02 \mathrm{mg} \mathrm{L}^{-1}\right)\end{array}$ & N/A \\
\hline & Dissolved Fe(total) & $\mathrm{mg} \mathrm{L}^{-1}$ & $\begin{array}{c}\text { Hach }^{\circledR} \text { DR2800 } \\
\text { Spectrophotometer } \\
\left(\mathrm{MDL}=0.02 \mathrm{mg} \mathrm{L}^{-1}\right)\end{array}$ & N/A \\
\hline 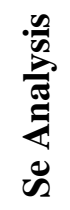 & Dissolved $\mathrm{Se}^{\mathrm{IV}}$ & $\mu g \mathrm{~L}^{-1}$ & $\begin{array}{c}\text { Perkin Elmer Optima } \\
2100 \text { DV ICP-OES } \\
\left(\mathrm{MDL}=5 \mu \mathrm{g} \mathrm{L}^{-1}\right)\end{array}$ & WinLab 32 ICP \\
\hline
\end{tabular}


Light intensity was monitored using $\mathrm{HOBO}^{\circledR}$ Pendant light/temperature loggers and an AccuPAR Model LP-80 PAR/LAI ceptometer (Table 4-2). The HOBO ${ }^{\circledR}$ Pendants measured light intensity in units of Lux (1 lumen $/ \mathrm{m}^{2}$ ) and were set to a five minute logging interval. The AccuPAR ceptometer measured light intensity in units of $\mu \mathrm{Mol} / \mathrm{m}^{2} \mathrm{~s}$, and measurements were taken periodically throughout each experiment. Maximum light intensities were measured at $4168 \mathrm{Lux}$ and $193 \mu \mathrm{Mol} / \mathrm{m}^{2} \mathrm{~s}$ with the light located 3 inches above the top of each reaction vessel.

Solution $\mathrm{pH}$ was monitored using DrDAQ ${ }^{\circledR} \mathrm{pH}$ probes. The $\mathrm{pH}$ was recorded in one second intervals and was displayed real-time during the experiments using PicoLog Recorder software. Before each temperature cycle, each probe was placed in a pH 4 buffer to correct for any differences in $\mathrm{pH}$ readings between the probes. The $\mathrm{pH}$ was recorded in standard units (Table 4-2).

\subsection{Sampling and analysis}

The volume of sample removed from each beaker did not exceed $10 \%$ of the total solution volume (one liter). This was to ensure that the solid to solution ratio was preserved.

\subsubsection{Fe sampling and analysis}

Unfiltered $\mathrm{Fe}^{\mathrm{II}}$ and $\mathrm{Fe}$ (total) samples were collected for each experiment. Selected sets of $\mathrm{Fe}^{\mathrm{II}}$ and $\mathrm{Fe}$ (total) samples were collected in triplicate to determine the error in the measurement. $\mathrm{Fe}^{\mathrm{II}}$ and $\mathrm{Fe}$ (total) concentrations were determined by the ferrozine method (Stookey, 1970) using a Hach ${ }^{\circledR}$ DR 2800 Spectrophotometer (Table 4-2). A ferrozine solution was prepared containing HEPES buffer (OmniPur, NJ, USA), ferrozine (HACH, CO, USA), and $\mathrm{NaOH}$ (Fisher Scientific, $\mathrm{NJ}, \mathrm{USA}$ ). The ferrozine solution reacts with $\mathrm{Fe}^{\mathrm{II}}$ in aqueous samples to form a purple colored complex (Figure 4-5) that can be analyzed spectrophotometrically at a wavelength of $562 \mathrm{~nm}$. Fresh ferrozine reagent was made for each cycle to ensure proper chemical composition and the optimal pH range between 4 and 9 (Stookey, 1970). 


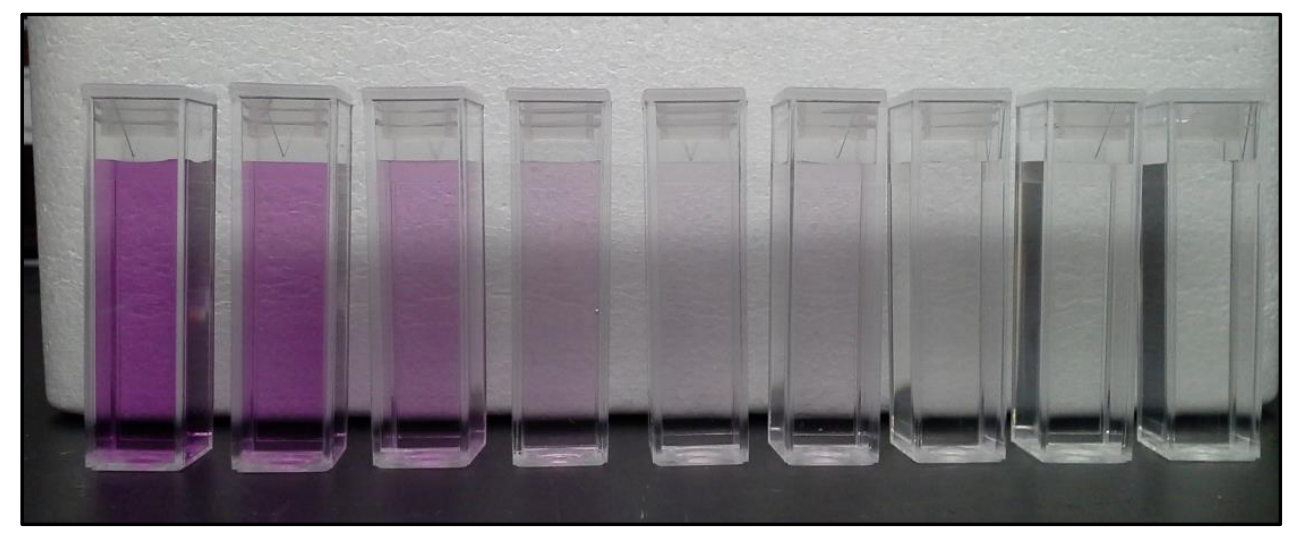

Figure 4-5. Ferrozine method calibration samples for $\mathrm{Fe}^{\mathrm{II}}$ analysis. Fe ${ }^{\mathrm{II}}$ concentrations decrease from left to right as indicated by the different shades of purple. 
Specific ferrozine to sample ratios were used to determine $\mathrm{Fe}^{\mathrm{II}}$ concentrations (Table 43). Each ferrozine-sample solution was made in a $4.5 \mathrm{~mL}$ cuvette, and the absorbance of each ferrozine-sample solution was analyzed using the Hach® DR2800 Spectrophotometer. Different calibration curves were created for each ferrozine to sample ratio by diluting ferrous ammonium sulfate hexahydrate $\left(\mathrm{Fe}\left(\mathrm{NH}_{4}\right)_{2}\left(\mathrm{SO}_{4}\right)_{2} \cdot 6 \mathrm{H}_{2} \mathrm{O}\right)(\mathrm{HACH}, \mathrm{CO}, \mathrm{USA})$ stock solutions of $100 \mathrm{mg} / \mathrm{L}$ $\mathrm{Fe}^{\mathrm{II}}$ and $10 \mathrm{mg} / \mathrm{L} \mathrm{Fe}^{\mathrm{II}}$. Once the calibration curves were created, $\mathrm{Fe}^{\mathrm{II}}$ concentrations were calculated from absorbance values. A blank was prepared using ferrozine and a solution with the same $\mathrm{pH}$ (3 standard units) and ionic strength $(0.1 \mathrm{M} \mathrm{KCl})$ as the vessel solutions.

$\mathrm{Fe}$ (total) concentrations were analyzed using the same method as $\mathrm{Fe}^{\mathrm{II}}$ analysis, except a solution of $0.5 \mathrm{~N}$ hydroxylamine $\mathrm{HCl}$ (HX) (Acros Organics, NJ, USA) was added to each sample before adding ferrozine reagent (Table 4-3). HX is a reducing agent that converts all dissolved Fe to $\mathrm{Fe}^{\mathrm{II}}$. Ferrozine was added to each $\mathrm{HX}$-sample solution and reacted with the $\mathrm{Fe}^{\mathrm{II}}$ to form the purple colored complex, which was then analyzed spectrophotometrically for Fe(total). A separate calibration curve was completed for the Fe(total) analysis, and a separate blank was also prepared using ferrozine, $\mathrm{HX}$, and a solution with the same $\mathrm{pH}$ and ionic strength as the vessel solutions. Fe ${ }^{\mathrm{III}}$ concentrations were calculated by subtracting $\mathrm{Fe}^{\mathrm{II}}$ concentrations from Fe(total) concentrations. The HACH DR 2800 method detection limit (MDL) for both Fe ${ }^{\text {II }}$ and Fe(total) is $0.02 \mathrm{mg} / \mathrm{L}$.

\subsubsection{Se sampling and analysis}

Samples were collected in triplicate for $\mathrm{Se}^{\mathrm{IV}}$. Specific ratios of sample, DI water, and $6 \mathrm{M}$ $\mathrm{HCl}$ were used (Table 4-4). Elemental Se concentrations were analyzed using a Perkin Elmer (CT, USA) Optima 2100 DV ICP-OES, which was operated in axial viewing mode at a wavelength of $196.03 \mathrm{~nm}$ (Table 4-5). A multimode sample introduction system (MSIS) was used in vapor generation mode (Figure 4-6).

In vapor generation mode, the nebulizer is used as the argon flow input to the chamber. The sample introduction line connected to the nebulizer is blocked off for this method. The $\mathrm{Se}^{\mathrm{IV}}$ sample containing approximately $4.8 \mathrm{M} \mathrm{HCl}$ is introduced via the hydride sample input at the base of the chamber, which flows into the reaction cone. Sodium borohydride $\left(\mathrm{NaBH}_{4}\right)$ solution 
Table 4-3. Ferrozine method sample to solution ratios for $\mathrm{Fe}^{\mathrm{II}}$ and $\mathrm{Fe}($ total) analysis

\begin{tabular}{l|cc|c}
\hline \multirow{2}{*}{$\begin{array}{l}\text { Type of Fe } \\
\text { analysis }\end{array}$} & \multicolumn{3}{|c}{ Sample to Ferrozine/HX ratios } \\
\cline { 2 - 4 } & $\begin{array}{c}\text { Unfiltered Fe } \\
\text { Sample (mL) }\end{array}$ & $\begin{array}{c}\text { Ferrozine } \\
(\mathbf{m L})\end{array}$ & $\begin{array}{c}\text { HX } \\
(\mathbf{m L})\end{array}$ \\
\hline $\mathrm{Fe}^{\mathrm{II}}$ & 0.5 & 3 & --- \\
$\mathrm{Fe}$ (total) & 0.5 & 1.5 & 1.5 \\
\hline
\end{tabular}

Note: HX is hydroxylamine hydrochloride. 
Table 4-4. Ratios of sample, DI water, and $6 \mathrm{M} \mathrm{HCl}$ prepared for $\mathrm{Se}^{\mathrm{IV}}$ HG-ICP-OES analysis

\begin{tabular}{l|c|c|c}
\hline \multirow{2}{*}{$\begin{array}{l}\text { Se sample } \\
\text { type }\end{array}$} & \multicolumn{3}{|c}{ Sample component ratios } \\
\cline { 2 - 4 } & $\begin{array}{c}\text { Sample } \\
(\mathbf{m L})\end{array}$ & $\begin{array}{c}\text { DI water } \\
(\mathbf{m L})\end{array}$ & $\begin{array}{c}\text { 6 M HCl } \\
(\mathbf{m L})\end{array}$ \\
\hline $\mathrm{Se}^{\mathrm{IV}}$ & 1 & 4 & 0.5 \\
\hline
\end{tabular}

Note: DI is deionized water. 
Table 4-5. HG-ICP-OES Se ${ }^{\mathrm{IV}}$ analysis parameters

\begin{tabular}{ll}
\hline HG-ICP-OES method parameters & \\
\hline Chamber type & MSIS \\
Nebulizer & Mira Mist \\
Plasma view & Axial \\
Wavelength $(\mathrm{nm})$ & 196.026 \\
Reductant solution & $0.5 \%(\mathrm{~m} / \mathrm{V}) \mathrm{NaBH}_{4}+0.05 \% \mathrm{NaOH}(\mathrm{m} / \mathrm{V})$ \\
Reductant uptake rate $\left(\mathrm{mL} \mathrm{min}^{-1}\right)$ & 1.2 \\
Sample $\mathrm{HCl}$ acidity & $4.8-7 \mathrm{M}$ \\
Sample flow rate $\left(\mathrm{mL} \mathrm{min}^{-1}\right)$ & 1.2 \\
ICP RF Power $($ watts $)$ & 1300 \\
Plasma Argon Flow $\left(\mathrm{L} \mathrm{min}^{-1}\right)$ & 15 \\
Nebulizer Argon $\left(\mathrm{L} \mathrm{min}^{-1}\right)$ & 0.65 \\
Auxiliary Argon $\left(\mathrm{L} \mathrm{min}{ }^{-1}\right)$ & 0.2 \\
Delay time (s) & 120 \\
Integration time & Auto \\
Replicates & 7 \\
Calibration standards & $0,5,10,50,100,150$, and $200\left(\mu \mathrm{g} / \mathrm{L} \mathrm{Se} \mathrm{IV}^{\mathrm{IV}}\right)$ \\
\hline
\end{tabular}

Note: MSIS is multimode sample introduction system. 


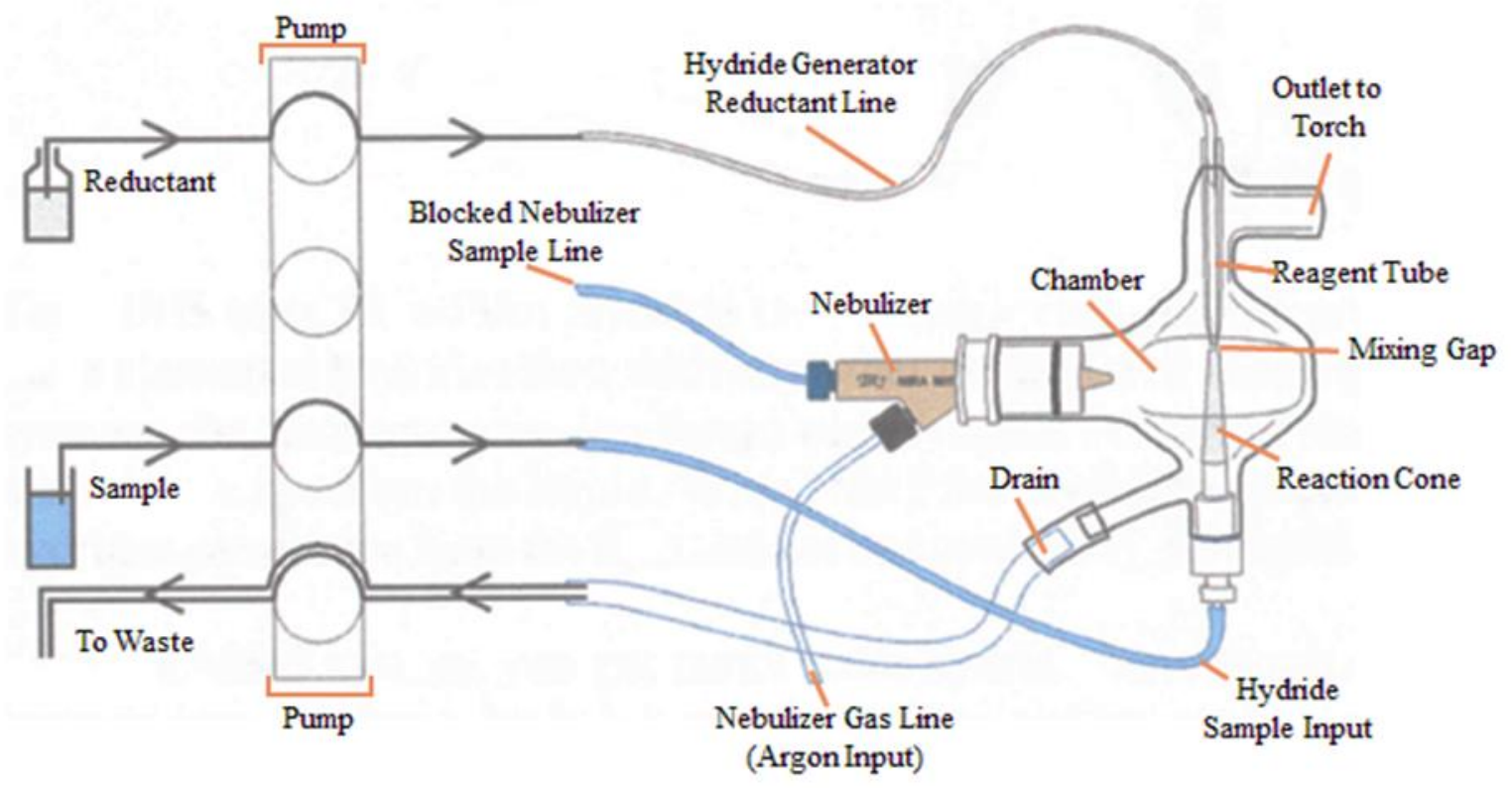

Figure 4-6. Multimode sample introduction system (MSIS) using vapor generation mode (modified from Marathon Scientific, 2007). 
is introduced from the top of the chamber via the hydride generator reductant line and flows into the reagent tube. A thin-film of sample containing $\mathrm{HCl}$ and $\mathrm{NaBH}_{4}$ meet in the mixing gap, a 1$3 \mathrm{~mm}$ gap between the tip of the reaction cone and the reagent tube (Figure 4-6). The reaction between the $\mathrm{HCl}$ and the $\mathrm{NaBH}_{4}$ creates a volatile Se hydride, a process called hydride generation (HG), which is then introduced to the plasma for analysis via an alumina injector. The $\mathrm{HG}$ reaction between $\mathrm{Se}^{\mathrm{IV}}$ (specifically the $\mathrm{Se}^{\mathrm{IV}} \mathrm{O}_{3}{ }^{2-}$ species) and $\mathrm{NaBH}_{4}$ is written as (Huang, 2010):

$$
3 \mathrm{BH}_{4}^{-}+2 \mathrm{Se}^{\mathrm{IV}} \mathrm{O}_{3}^{2-}+7 \mathrm{H}^{+} \rightarrow 2 \mathrm{H}_{2} \mathrm{Se} \uparrow+4 \mathrm{H}_{2} \uparrow+3 \mathrm{H}_{3} \mathrm{BO}_{3}
$$

The liquid that does not volatilize inside the chamber exits the chamber through the drain into a waste container (Schroder and Zhang, 2009).

The reagents used to make Se standards included a $1000 \mathrm{mg} / \mathrm{L} \mathrm{Se}^{4+}$ reference standard purchased from Spex CertiPrep (NJ, USA) and $12 \mathrm{M} \mathrm{HCl}$ (Fisher Scientific, NJ, USA). This is the same standard that was used to make the vessel solutions for sample collection. Therefore, Se is assumed to be in the $\mathrm{Se}^{\mathrm{IV}}$ oxidation state for the HG-ICP-OES standards. Sodium borohydride (Acros, NJ, USA) was used to make a $0.5 \%(\mathrm{~m} / \mathrm{v}) \mathrm{NaBH}_{4}$ solution. The resulting solution was stabilized with $0.05 \%$ (m/v) NaOH (Fisher Scientific, NJ, USA).

Six calibration standards of $5 \mu \mathrm{g} / \mathrm{L}, 10 \mu \mathrm{g} / \mathrm{L}, 50 \mu \mathrm{g} / \mathrm{L}, 100 \mu \mathrm{g} / \mathrm{L}, 150 \mu \mathrm{g} / \mathrm{L}$, and $200 \mu \mathrm{g} / \mathrm{L}$ $\mathrm{Se}^{\mathrm{IV}}$ were prepared with a reference stock $\mathrm{Se}^{\mathrm{IV}}$ solution of $1000 \mu \mathrm{g} / \mathrm{L}$ in $10 \%$ (v/v) $6 \mathrm{M} \mathrm{HCl}$. The reference stock was prepared using the Spex CertiPrep $1000 \mathrm{mg} / \mathrm{L} \mathrm{Se}{ }^{4+}$ ICP-OES standard. This was also the same standard used to make the vessel solutions for sample collection. The blank was $10 \%(\mathrm{v} / \mathrm{v}) 6 \mathrm{M} \mathrm{HCl}$ and DI water. Instrument stability was evaluated before each sample run by taking three replicate readings of a blank and each Se standard. The ICP-OES was run using WinLab 32 ICP software, and results (analyzed as elemental Se) were printed at the end of each analysis. Results were accepted at relative standard deviation $(\mathrm{RSD}=$ standard deviation/mean $\mathrm{x}$ 100) values less than $3 \%$.

The MDL was calculated by running a linear regression analysis on five different calibration curves in Microsoft Excel using the Data Analysis Toolpak. This method calculates the limit of detection (LOD), which is the same as the MDL for a single analyte ( $\mathrm{Se}^{\mathrm{IV}}$ is the only analyte in the HG-ICP-OES method). The values for the upper 95\% confidence interval of the 
regression analysis output were averaged for the five calibration curves to calculate the final LOD value. The LOD can also be calculated by following the method of Konieczka and Namiesnik (2009), in which the LOD for an individual calibration curve can be calculated as follows:

$$
\mathrm{LOD}=\frac{3 \times \mathrm{SE}(\mathrm{I})}{\mathrm{S}}
$$

Where $\mathrm{SE}(\mathrm{I})$ is the standard error of the intercept and $\mathrm{S}$ is the slope of the calibration curve. The LOD result for this equation is equivalent to the $95 \%$ confidence interval output value in Microsoft Excel. Therefore, the final MDL was calculated by averaging the LOD results for all five calibration curves. The average MDL was $5 \mu \mathrm{g} / \mathrm{L} \mathrm{Se}{ }^{\mathrm{IV}}$.

\subsection{Data analysis}

Graphs of each parameter (temperature, $\mathrm{pH}, \mathrm{Fe}^{\mathrm{II}}$ concentrations, $\mathrm{Fe}^{\mathrm{III}}$ concentrations, $\mathrm{Fe}\left(\right.$ total) concentrations, and $\mathrm{Se}^{\mathrm{IV}}$ concentrations) versus time were created for each cycle with standard deviations for replicate samples. Replications of each experiment were performed to provide statistical validation. The Fe ratio was calculated and plotted for each cycle by dividing $\mathrm{Fe}^{\mathrm{II}}$ concentrations by $\mathrm{Fe}$ (total) concentrations. Graphs of Se concentrations versus temperature were created to identify relationships between the two parameters. To test whether Se concentrations varied due to temperature-dependent sorption, 1/temperature (in Kelvin) was

graphed versus the log of Se concentrations to determine the enthalpy of sorption for $\mathrm{Se}^{\mathrm{IV}}$ onto 2line ferrihydrite (Eq. 4 and Eq. 5).

Each cycle was also categorized into a group (Fe-only, Se-only, Fe-Se combined) to identify similarities and differences in the data.

\subsection{Quality Control Assessment}

Before and during the experiments, a few quality control tests were completed to determine the state of Fe (i.e. dissolved or colloidal) in the reaction vessels and to determine the 
controlling processes of Se concentration changes and cycling. The possible states of Se in the reaction vessels are written in the mass balance equation below:

$[\mathrm{Se}]_{\text {Total }}=\left[\mathrm{Se}^{\mathrm{IV}}\right]_{\text {aqueous }}+\left[\mathrm{Se}^{\mathrm{IV}}\right]_{\text {sorbed to glass }}+\left[\mathrm{Se}^{\mathrm{IV}}\right]_{\text {sorbed to Fe }}+\left[\mathrm{Se}^{\mathrm{VI}}\right]_{\text {aqueous }}+$

$\left[\mathrm{Se}^{\mathrm{VI}}\right]_{\text {sorbed to glass }}+\left[\mathrm{Se}^{\mathrm{VI}}\right]_{\text {sorbed to } \mathrm{Fe}}$

[Eq. 10]

Equation 10 shows that $\mathrm{Se}^{\mathrm{IV}}$ may oxidize to $\mathrm{Se}^{\mathrm{VI}}$. However, $\mathrm{Se}^{\mathrm{IV}}$ is expected to be the dominant Se species in solution, because $\mathrm{Se}^{\mathrm{IV}}$ to $\mathrm{Se}^{\mathrm{VI}}$ oxidation is kinetically slow (Torres et al., 2011). Both $\mathrm{Se}^{\mathrm{IV}}$ and $\mathrm{Se}^{\mathrm{VI}}$ are likely to sorb to solid 2-line ferrihydrite. It is also possible that $\mathrm{Se}^{\mathrm{IV}}$ and $\mathrm{Se}^{\mathrm{VI}}$ may sorb to the glass reaction vessels. $\mathrm{Se}^{\mathrm{IV}}$ sorption to glassware is addressed in the quality control experiments (sections 4.6.3 and 4.6.4). $\mathrm{Se}^{\mathrm{IV}}$ to $\mathrm{Se}^{\mathrm{VI}}$ oxidation is discussed in section 6.2.5.

\subsubsection{Filtering experiment for Fe analysis}

An experiment was conducted to determine if ferrozine solution can react with both dissolved and colloidal/particulate $\mathrm{Fe}^{\mathrm{II}}$. Six vessels were prepared using the same solution as the Fe-only experiments; however, a different mass of 2-line ferrihydrite was added to each vessel (Table 4-6). The vessels equilibrated for 48 hours prior to sampling. Both filtered and unfiltered samples were collected from each vessel for $\mathrm{Fe}^{\mathrm{II}}$ and $\mathrm{Fe}$ (total) analysis. Every sample was collected in replicates of six, and a dedicated $0.45-\mu \mathrm{m}$ syringe filter was used for each vessel.

Two vessels (Vessel 1 and Vessel 6) were more turbid than the other four vessels (Figure 4-7). Vessels 1 and 6 were not water jacketed like the other four vessels. Therefore, better mixing of the solution occurred in these vessels due to a stronger response between the magnetic stirrer and stir plate.

For all vessels, the unfiltered $\mathrm{Fe}^{\mathrm{II}}$ and $\mathrm{Fe}$ (total) concentrations were higher than the filtered $\mathrm{Fe}^{\mathrm{II}}$ and Fe(total) concentrations (Table 4-6, Figure 4-8, Appendix B). Although the filtering process resulted in decreased $\mathrm{Fe}^{\mathrm{II}}$ absorbance values, it is unlikely that all colloidal/particulate $\mathrm{Fe}^{\mathrm{II}}$ was removed during the filtering process (i.e. some of the 
Table 4-6. Filtering experiment for Fe analysis: A comparison of unfiltered and filtered samples

\begin{tabular}{cc|cccc|cccc}
\hline \multirow{2}{*}{$\begin{array}{c}\text { Vessel } \\
\text { Number }\end{array}$} & $\begin{array}{c}\text { FH } \\
\text { added } \\
(\mathbf{m g})\end{array}$ & \multicolumn{3}{|c|}{ Fe $^{\mathrm{II}}$ Analysis } & \multicolumn{4}{c}{ Fe(total) Analysis } \\
\cline { 3 - 10 } & & $\begin{array}{c}\text { Unfiltered } \\
(\mathbf{m g} / \mathbf{L})\end{array}$ & $\begin{array}{c}\text { RSD } \\
(\boldsymbol{\%})\end{array}$ & $\begin{array}{c}\text { Filtered } \\
(\mathbf{m g} / \mathbf{L})\end{array}$ & $\begin{array}{c}\text { RSD } \\
(\%)\end{array}$ & $\begin{array}{c}\text { Unfiltered } \\
(\mathbf{m g} / \mathbf{L})\end{array}$ & $\begin{array}{c}\text { RSD } \\
(\%)\end{array}$ & $\begin{array}{c}\text { Filtered } \\
(\mathbf{m g} / \mathbf{L})\end{array}$ & $\begin{array}{c}\text { RSD } \\
(\%)\end{array}$ \\
\hline 1 & 100 & 0.252 & $4.5 \%$ & 0.146 & $6.0 \%$ & 0.759 & $1.6 \%$ & 0.644 & $1.8 \%$ \\
2 & 200 & 0.204 & $8.0 \%$ & 0.130 & $4.4 \%$ & 0.525 & $3.1 \%$ & 0.447 & $2.6 \%$ \\
3 & 300 & 0.232 & $2.4 \%$ & 0.155 & $15 \%$ & 0.597 & $0.0 \%$ & 0.487 & $1.2 \%$ \\
4 & 400 & 0.268 & $3.9 \%$ & 0.162 & $3.5 \%$ & 0.640 & $0.0 \%$ & 0.468 & $2.3 \%$ \\
5 & 500 & 0.232 & $2.4 \%$ & 0.151 & $4.8 \%$ & 0.398 & $6.5 \%$ & 0.272 & $2.1 \%$ \\
6 & 600 & 0.507 & $<1 \%$ & 0.160 & $<1 \%$ & 0.602 & $1.2 \%$ & 0.194 & $3.7 \%$ \\
\hline
\end{tabular}

Note: FH is 2-line ferrihydrite. Relative standard deviation (RSD) is the standard deviation divided by the mean reported as a percentage, where the corresponding mean value is listed as "Unfiltered" or "Filtered" data. 


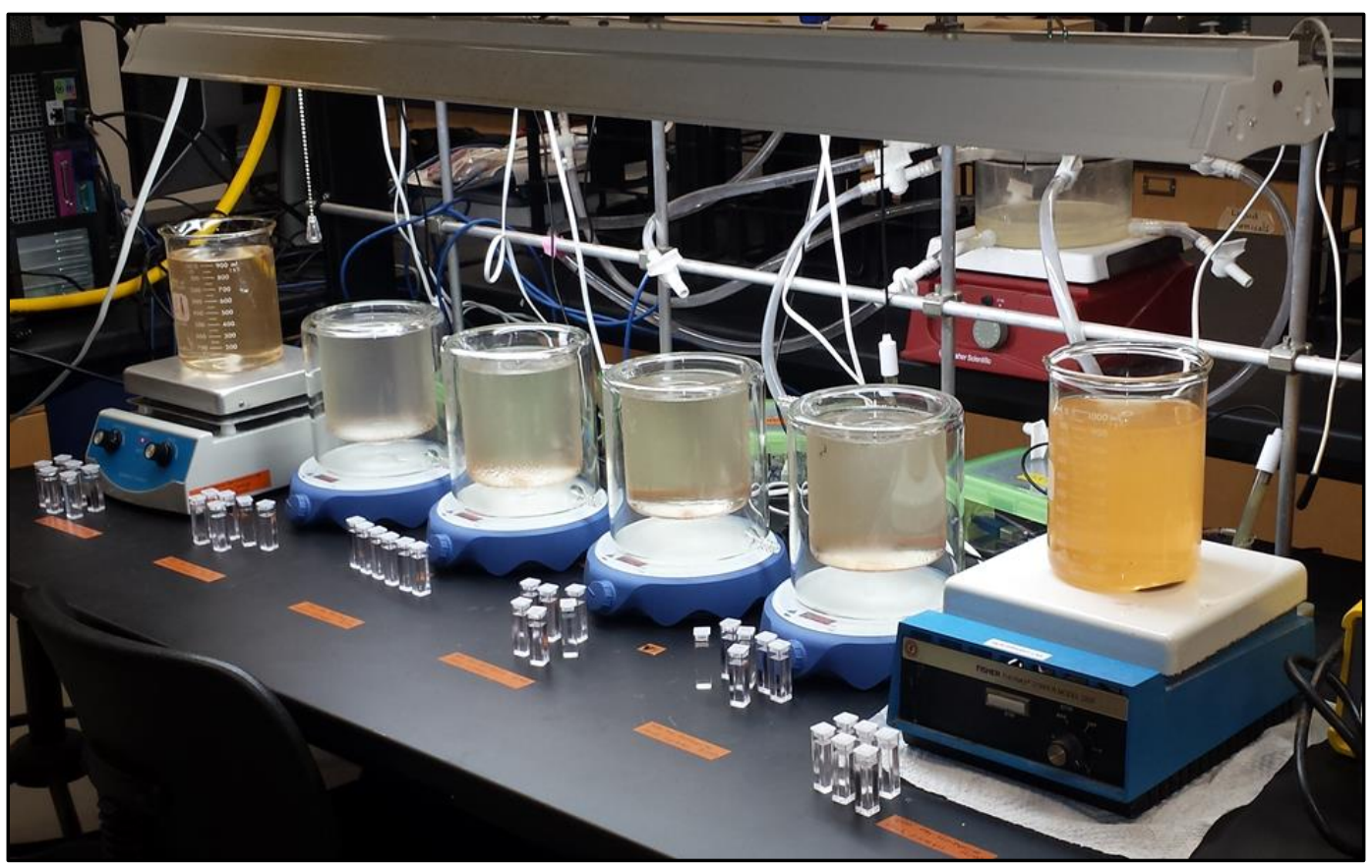

Figure 4-7. Photograph of the filtering experiment for Fe analysis. Vessels are numbered 1 through 6 from left to right. Vessels 1 and 6 are beakers, and vessels 2 through 5 are jacketed reaction vessels. 

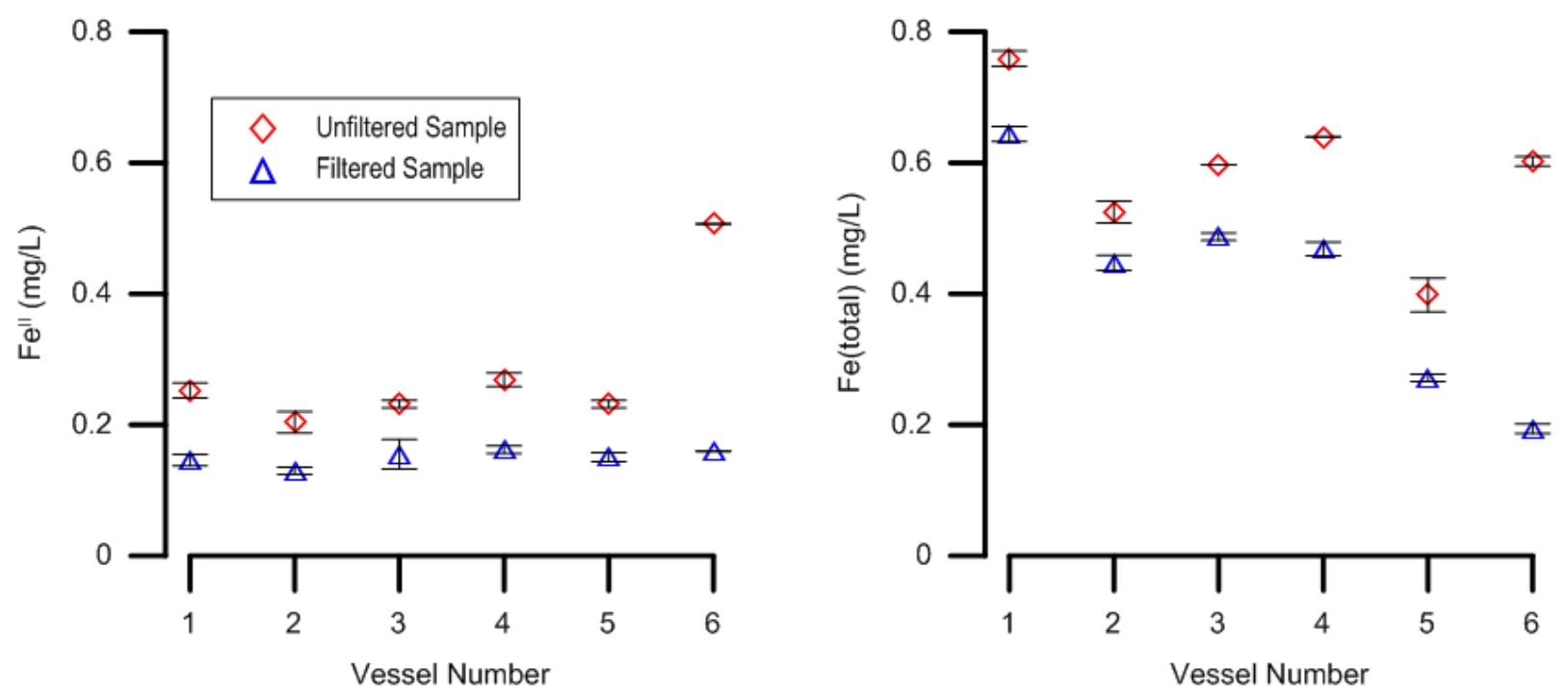

Figure 4-8. Results of the filtering experiment for $\mathrm{Fe}$ analysis showing the comparison between unfiltered and filtered samples analyzed for $\mathrm{Fe}^{\mathrm{II}}$ and $\mathrm{Fe}$ (total). Standard deviations are represented by error bars for six replicate samples. 
colloids/particles may have been small enough to pass through the $0.45 \mu \mathrm{m}$ filter). Ferrozine solution reduces all dissolved $\mathrm{Fe}^{\mathrm{III}}$ to $\mathrm{Fe}^{\mathrm{II}}$; however, it is not known if the ferrozine solution breaks down solid Fe or Fe colloids. Therefore, it is likely that the change in $\mathrm{Fe}^{\mathrm{II}}$ absorbance values from unfiltered to filtered samples was due to variations in light movement through the samples caused by the removal of particles during filtering. For Fe(total) samples, it is likely that the solid Fe/colloidal Fe was broken down by the hydroxylamine hydrocholoride; however, this process was not confirmed during this experiment. All reported $\mathrm{Fe}^{\mathrm{II}}$ and $\mathrm{Fe}$ (total) results for the light and temperature cycle experiments are for unfiltered samples which likely contained both dissolved and colloidal Fe.

Also, for Vessel 3 (which like the Fe-only and Fe-Se experiments contained $300 \mathrm{mg}$ of 2line ferrihydrite), an average of $0.597 \mathrm{mg} / \mathrm{L} \mathrm{Fe}$ (total) was found in unfiltered samples. This small $\mathrm{Fe}$ (total) concentration indicated that minimal 2-line ferrihydrite dissolution was occurring in the vessel after the equilibration period. A difference of $0.11 \mathrm{mg} / \mathrm{L}$ was calculated between unfiltered and filtered Fe(total) samples signifying that Fe colloids may have been present; however, the relative mass of those potential Fe colloids was much less than that of solid 2-line ferrihydrite (the mass of Fe colloids was approximately $0.07 \%$ of the total Fe added to the vessel). Therefore, $\mathrm{Se}^{\mathrm{IV}}$ sorption onto Fe colloids will likely be insignificant during light and temperature control experiments, because the mass of the Fe colloids will be much less than the mass of the solid 2-line ferrihydrite added to the vessels.

\subsubsection{Evaporation experiment}

Each reaction vessel remained uncovered throughout the duration of each Fe-only, Seonly, and Fe-Se cycle experiment. Therefore, an experiment was completed to determine if significant evaporation of the vessel solutions was occurring over the two day equilibration period before the Fe and Se cycle experiments began. This was important to determine, because it would explain increases in Fe and Se concentrations that might be observed over time.

For the evaporation experiment, four reaction vessels were prepared in the same manner as the Se-only experiments (section 4.2.2). Since the ionic strength was fixed with $\mathrm{KCl}(0.1 \mathrm{M}$ $\mathrm{KCl}), \mathrm{K}^{+}$concentrations were known for each vessel $\left(3548 \mathrm{mg} / \mathrm{L} \mathrm{K}^{+}\right)$and could be analyzed. 
Since $\mathrm{K}^{+}$acts as a conservative ion in the vessel solutions, an increase in $\mathrm{K}^{+}$concentrations over time can be attributed to evaporation.

Samples were collected from each vessel immediately after solution preparation (time $=0$ days). The vessels stirred for 2.3 days, and samples were collected from each vessel after 2 days and 2.3 days (Table 4-7). The $\mathrm{K}^{+}$concentrations increased over the 2.3 day experiment for all vessels. Therefore, evaporation from the vessels was confirmed. The results (Table 4-7) illustrate that up to a $10 \%$ increase in Se concentrations may be linked to evaporation. However, this error should not affect the trends in the cycling behavior of Se with temperature.

\subsection{3 $\mathrm{Se}^{\mathrm{IV}}$ loss from sorption to glass}

To determine if $\mathrm{Se}^{\mathrm{IV}}$ sorption to the glass vessels was occurring, Se-only solutions were tested as part of a complementary sorption study (Vesper et al., 2015). The maximum $\mathrm{Se}^{\mathrm{IV}}$ lost in those experiments was $15 \%$. This introduces some error; however, it should not eliminate the cycling behavior of Se during the temperature control experiments.

\subsection{4 $\mathrm{Se}^{\mathrm{IV}}$ desorption from glass}

An experiment was prepared to determine if $\mathrm{Se}^{\mathrm{IV}}$ was desorbing from the glass vessels and then being released in solution during later experiments. Two reaction vessels were prepared with the Se-only solution (section 4.2.2). The solutions stirred and equilibrated for 48 hours. Then each vessel was cleaned thoroughly with two different detergents. One vessel was cleaned with Sparkleen detergent, and the other was cleaned with Citranox acid detergent. The magnetic stir bars were also cleaned. After cleaning, the vessels were filled with a background solution to match the temperature control experiments. Each vessel contained one liter of DI water, $0.1 \mathrm{M}$ $\mathrm{KCl}$, and was adjusted to a $\mathrm{pH}$ of 3 with $\mathrm{HCl}$. The magnetic stir bars were placed back in the vessels and the solution equilibrated for 24 hours. Samples were collected at 4 hours, 6 hours, and 24 hours for $\mathrm{Se}^{\mathrm{IV}}$. All collected sample concentrations fell below the instrument MDL of 5 $\mu \mathrm{g} / \mathrm{L} \mathrm{Se} \mathrm{IV}^{\mathrm{IV}}$ indicating that $\mathrm{Se}^{\mathrm{IV}}$ sorption and subsequent desorption from the glass vessels could not be linked to increases in $\mathrm{Se}^{\mathrm{IV}}$ concentrations. 
Table 4-7. Evaporation experiment $\mathrm{K}^{+}$results

\begin{tabular}{cccc}
\hline $\begin{array}{c}\text { Vessel } \\
\text { No. }\end{array}$ & $\begin{array}{c}\text { Elapsed } \\
\text { time } \\
\text { (days) }\end{array}$ & $\begin{array}{c}\mathbf{K} \\
(\mathbf{m g} / \mathbf{L})\end{array}$ & $\begin{array}{c}\text { Change from } \\
\text { background } \\
(\%)\end{array}$ \\
\hline 1 & 0 & 3579 & $0.87 \%$ \\
& 2.03 & 3645 & $2.73 \%$ \\
& 2.33 & 3753 & $5.78 \%$ \\
\hline 2 & 0 & 3577 & $0.82 \%$ \\
& 2.03 & 3678 & $3.66 \%$ \\
& 2.33 & 3856 & $8.68 \%$ \\
\hline 3 & 0 & 3679 & $3.69 \%$ \\
& 2.03 & 3646 & $2.76 \%$ \\
& 2.33 & 3766 & $6.14 \%$ \\
\hline 4 & 0 & 3561 & $0.37 \%$ \\
& 2.03 & 3727 & $5.05 \%$ \\
& 2.33 & 3883 & $9.44 \%$ \\
\hline
\end{tabular}


Since Se sorption and desorption from glassware was minimal, Equation 10 for the mass balance of Se in the reaction vessels can be reduced to:

$[\mathrm{Se}]_{\text {Total }}=\left[\mathrm{Se}^{\mathrm{IV}}\right]_{\text {aqueous }}+\left[\mathrm{Se}^{\mathrm{IV}}\right]_{\text {sorbed to } \mathrm{Fe}}+\left[\mathrm{Se}^{\mathrm{VI}}\right]_{\text {aqueous }}+\left[\mathrm{Se}^{\mathrm{VI}}\right]_{\text {sorbed to Fe }}$

[Eq. 11] 


\section{RESULTS}

Seven experiments were conducted in which light, temperature, length of experiment, and $\mathrm{Se}^{\mathrm{IV}}$ concentrations varied (Table 5-1). Raw data for each cycle can be found in Appendix C.

\subsection{Cycle 1: 7/22-23/2014}

A 22-hour Fe-only light cycle was conducted on July 22-23, 2014 (Table 5-1). The purpose of this experiment was to determine if Fe redox cycles could be generated by light only (no temperature control variations). One reaction vessel was set up for this experiment using a Fe-only solution (Table 4-1), which equilibrated for two hours before the experiment began. The light located above the reaction vessel was turned on and off two times during the experiment (Figure 5-1).

Results of this experiment (Figure 5-1 and Table 5-2) illustrated that Fe(total) concentrations continued to increase after the two hour equilibration period with the light on. Temperature was not intentionally cycled during this experiment; however, the solution temperature increased to $22.1^{\circ} \mathrm{C}$ when the light was turned on and decreased to $20.9^{\circ} \mathrm{C}$ when the light was turned off. Therefore, it was determined that the effects of temperature and light could not be separated (due to heating of the solution when the light was turned on). The average light intensity was 4119 Lux for periods when the light was turned on.

It was also determined that a longer equilibration time was needed before sample collection to obtain stable Fe(total) concentrations and values above the MDL of $0.02 \mathrm{mg} / \mathrm{L}$. It took approximately 8 hours for the Fe(total) concentrations to rise above the MDL in this experiment. Fe(total) concentrations were low $(\leq 0.228 \mathrm{mg} / \mathrm{L})$, and $\mathrm{Fe}^{\mathrm{II}}$ concentrations did not exceed the MDL, even during times when the light was turned on. Iron cycles were not observed during this experiment. The solution $\mathrm{pH}$ did not cycle with light or temperature changes.

Fe cycles did not occur during this light control experiment with changes in light or temperature. There are a few possible reasons why $\mathrm{Fe}^{\mathrm{III}}$ photoreduction did not occur. First, the $\mathrm{Fe}$ (total) concentrations present in solution were low (Table 5-2). If $\mathrm{Fe}^{\mathrm{III}}$ photoreduction was occurring, the $\mathrm{Fe}^{\mathrm{III}}$ species concentrations in solution may not have been sufficient to 
Table 5-1. Summary of light and temperature cycle experiments

\begin{tabular}{|c|c|c|c|c|c|c|c|c|c|}
\hline $\begin{array}{l}\text { Cycle } \\
\text { No. } \\
\end{array}$ & Purpose & $\begin{array}{c}\text { Cycle } \\
\text { date(s) }\end{array}$ & $\begin{array}{c}\text { No. of } \\
\text { Vessels } \\
\end{array}$ & $\begin{array}{l}\mathbf{F H}^{\mathrm{a}} \\
(\mathrm{mg}) \\
\end{array}$ & $\begin{array}{l}\mathrm{Se}^{\mathrm{IVb}} \\
(\mu \mathrm{g} / \mathrm{L})\end{array}$ & Light & Temp & $\begin{array}{l}\text { Sampled } \\
\text { for }\end{array}$ & $\begin{array}{l}\text { Duration \& } \\
\text { sampling }^{c}\end{array}$ \\
\hline 1 & $\begin{array}{l}\text { Generate Fe cycles using } \\
\text { light only }\end{array}$ & $7 / 22-23 / 14$ & 1 & 500 & --- & cycle & $\begin{array}{l}\text { stable } \\
\sim 25^{\circ} \mathrm{C}\end{array}$ & $\begin{array}{l}\mathrm{Fe}^{\mathrm{II}} \\
\mathrm{Fe}(\text { total })\end{array}$ & $\begin{array}{l}\text { Equil.: } 2 \mathrm{hr} \\
\text { Cycle: } 22 \mathrm{hr} \\
\text { Samples: hourly }\end{array}$ \\
\hline 2 & $\begin{array}{l}\text { Generate Fe cycles using } \\
\text { light only over a longer } \\
\text { time period }\end{array}$ & $10 / 17-18 / 14$ & 4 & 500 & --- & cycle & $\begin{array}{l}\text { stable } \\
\sim 25^{\circ} \mathrm{C}\end{array}$ & $\begin{array}{l}\mathrm{Fe}^{\mathrm{II}} \\
\mathrm{Fe}(\text { total })\end{array}$ & $\begin{array}{l}\text { Equil.: } 48 \mathrm{hr} \\
\text { Cycle: } 30 \mathrm{hr} \\
\text { Samples: hourly }\end{array}$ \\
\hline 3 & $\begin{array}{l}\text { Generate Fe-Se cycles } \\
\text { with temperature }\end{array}$ & $10 / 25 / 14$ & 4 & 500 & 3000 & off & cycle & $\begin{array}{l}\mathrm{Fe}^{\mathrm{II}} \\
\mathrm{Fe}(\text { total }) \\
\mathrm{Se}^{\mathrm{IV}}\end{array}$ & $\begin{array}{l}\text { Equil.: } 48 \mathrm{hr} \\
\text { Cycle: } 10 \mathrm{hr} \\
\text { Samples: hourly }\end{array}$ \\
\hline 4 & $\begin{array}{l}\text { Generate Fe-only and Fe- } \\
\text { Se cycles with }\end{array}$ & $12 / 9 / 14$ & 2 & 500 & --- & on & cycle & $\begin{array}{l}\mathrm{Fe}^{\mathrm{II}} \\
\mathrm{Fe}(\text { total) }\end{array}$ & $\begin{array}{l}\text { Equil.: } 48 \mathrm{hr} \\
\text { Cycle: } 10 \mathrm{hr}\end{array}$ \\
\hline & & & 2 & 500 & 300 & & & & \\
\hline 5 & $\begin{array}{l}\text { Generate Se-only cycles } \\
\text { with temperature over a } \\
\text { shorter time period }\end{array}$ & $1 / 29 / 15$ & 4 & --- & 300 & on & cycle & $\mathrm{Se}^{\mathrm{IV}}$ & $\begin{array}{l}\text { Equil.: } 48 \mathrm{hr} \\
\text { Cycle: } 3.5 \mathrm{hr} \\
\text { Samples: } 15-30 \text { mins }\end{array}$ \\
\hline \multirow[b]{2}{*}{6} & \multirow{2}{*}{$\begin{array}{l}\text { Generate Fe-only and Fe- } \\
\text { Se combined cycles with } \\
\text { temperature }\end{array}$} & \multirow[b]{2}{*}{$2 / 28 / 15$} & 2 & 500 & --- & off & cycle & $\begin{array}{l}\mathrm{Fe}^{\mathrm{II}} \\
\mathrm{Fe}(\text { total })\end{array}$ & $\begin{array}{l}\text { Equil.: } 48 \mathrm{hr} \\
\text { Cycle: } 7 \mathrm{hr} \\
\text { Samples: random }\end{array}$ \\
\hline & & & 2 & 500 & 300 & off & cycle & $\begin{array}{l}\mathrm{Fe}^{\mathrm{II}} \\
\mathrm{Fe}(\text { total) } \\
\mathrm{Se}^{\mathrm{IV}}\end{array}$ & $\begin{array}{l}\text { Equil.: } 48 \mathrm{hr} \\
\text { Cycle: } 7 \mathrm{hr} \\
\text { Samples: random }\end{array}$ \\
\hline 7 & $\begin{array}{l}\text { Generate Se-only cycles } \\
\text { with temperature }\end{array}$ & $4 / 26 / 15$ & 4 & --- & 300 & on & cycle & $\mathrm{Se}^{\mathrm{IV}}$ & $\begin{array}{l}\text { Equil.: } 48 \mathrm{hr} \\
\text { Cycle: } 7 \mathrm{hr} \\
\text { Samples: random }\end{array}$ \\
\hline
\end{tabular}

${ }^{\mathrm{a}}$ 2-line ferrihydrite; ${ }^{\mathrm{b}}$ diluted from $1000 \mathrm{mg} / \mathrm{L} \mathrm{Se}{ }^{\mathrm{IV}}$ standard; ${ }^{\mathrm{c}}$ Equil. = equilibration time before experiment begins; Cycle = duration of test from end of equilibration; Samples = frequency of sample collection. All vessels contained $7.45 \mathrm{~g} \mathrm{KCl}(0.1 \mathrm{M})$; adjusted to $\mathrm{pH}$

$\sim 3$ (adjusted with $\mathrm{HCl}$ ); brought to a total of $1 \mathrm{~L}$ 


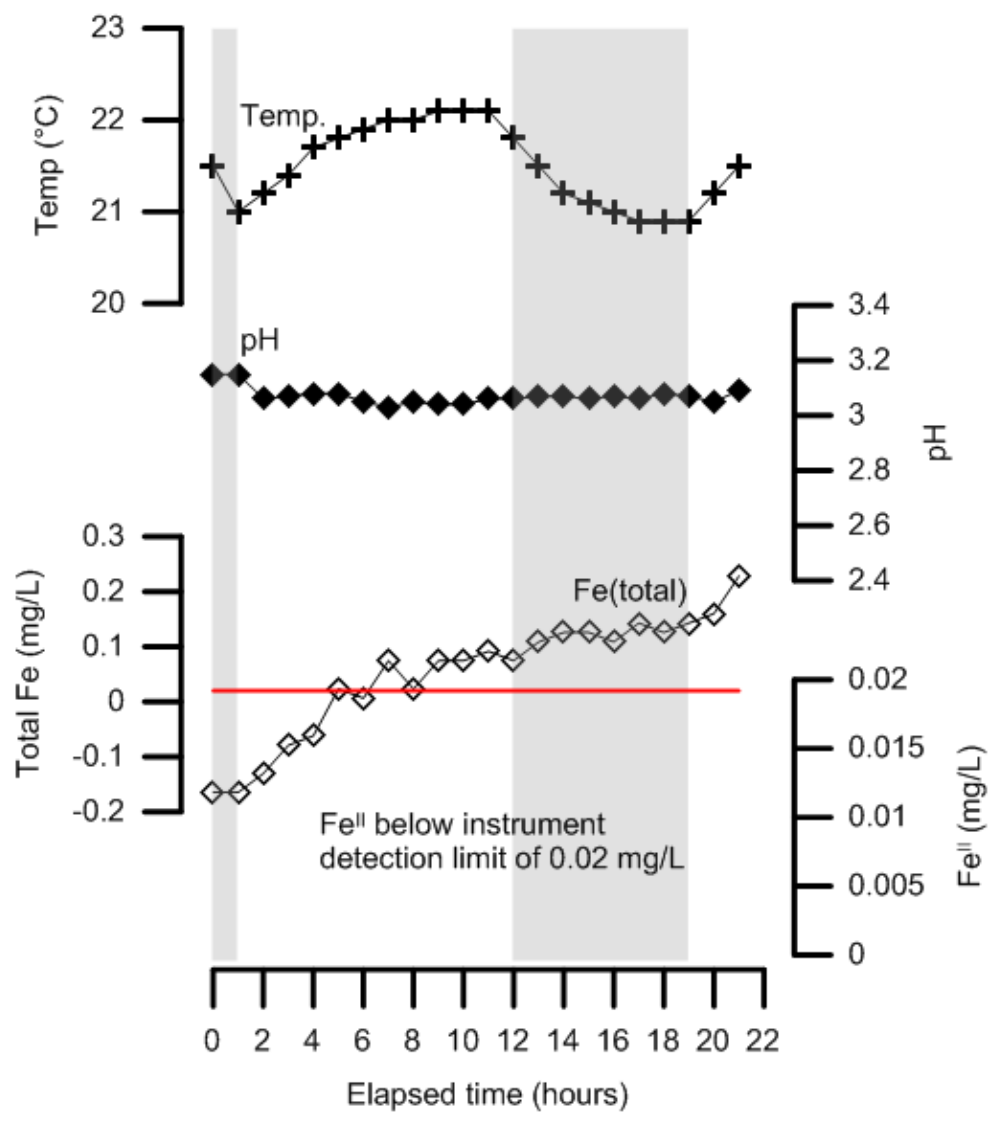

Figure 5-1. Cycle 1 (7/22-23/2014) results. A single vessel was set up for this experiment containing Fe-only solution. The straight, solid line indicates the MDL for $\mathrm{Fe}^{\mathrm{II}}$ analysis $\left(0.02 \mathrm{mg} / \mathrm{L} \mathrm{Fe}^{\mathrm{II}}\right)$ on the HACH DR2800 Spectrophotometer. The gray shaded areas indicate when the light was turned off (dark conditions). 
Table 5-2. Cycle 1 (7/22-23/2014) parameter variability

\begin{tabular}{lcccccc}
\hline Parameter & Units & $\begin{array}{c}\text { Vessel } \\
\text { No. }\end{array}$ & Min. & Max. & $\begin{array}{c}\text { Range } \\
\text { (Min. - Max.) }\end{array}$ & Average \\
\hline Temperature & ${ }^{\circ} \mathrm{C}$ & 1 & 20.9 & 22.1 & 1.2 & 21.5 \\
\hline $\mathrm{pH}$ & --- & 1 & 3.03 & 3.15 & 0.12 & 3.07 \\
\hline $\mathrm{Fe}$ (total) & $\mathrm{mg} / \mathrm{L}$ & 1 & $<0.02$ & 0.228 & 0.392 & 0.051 \\
\hline
\end{tabular}

Note: Min. is the minimum parameter value, and Max. is the maximum parameter value. 
produce $\mathrm{Fe}^{\mathrm{II}}$ concentrations above the MDL. Second, the period in which the light was turned on may not have been long enough for $\mathrm{Fe}^{\mathrm{III}}$ photoreduction to occur and yield $\mathrm{Fe}^{\mathrm{II}}$ at detectible limits. Lastly, the light intensity may not have been strong enough to drive $\mathrm{Fe}^{\mathrm{III}}$ photoreduction.

\subsection{Cycle 2: 10/17-18/2014}

A 30-hour Fe-only light cycle was conducted on October 17-18, 2014 (Table 5-1). The purpose of this experiment was to complete multiple Fe-only cycles with a longer equilibration time (48 hours) and a longer sampling period than the previous experiment. Similar to Cycle 1, the goal was to generate Fe cycles by light and/or temperature changes (temperature controlled by light only). The light was turned on and off twice during the experiment (Figures 5-2 and 53).

Four reaction vessels containing Fe-only solutions (Table 4-1) were prepared for this experiment. The temperature remained relatively stable in all vessels (Figures 5-2 and 5-3, Table 5-3). The average light intensity was 3759 Lux for periods when the light was turned on. The $\mathrm{pH}$ also remained relatively stable for all vessels, with the exception of Vessel 3 . The Vessel $3 \mathrm{pH}$ was adjusted to 3.14 during hour 13, because the $\mathrm{pH}$ of that vessel was low in comparison to the other three vessels (Figure 5-3, Table 5-3). The data clearly confirm that an adjustment in $\mathrm{pH}$ has an effect on Fe concentrations. As the $\mathrm{pH}$ increased in Vessel 3, Fe(total) concentrations decreased and $\mathrm{Fe}^{\mathrm{II}}$ concentrations increased. Regardless of the change in $\mathrm{pH}$ for Vessel 3, each vessel displayed the same trends in Fe(total) and $\mathrm{Fe}^{\mathrm{II}}$ concentrations over time (Figure 5-3). At approximately hour 22, Fe(total) concentrations appeared to increase with a slight lag behind an increase in temperature; however, the Fe(total) concentration changes did not correspond with changes in light intensity (light on versus light off conditions). In Vessel 2, $\mathrm{Fe}^{\mathrm{II}}$ concentrations steadily increased in light on conditions and stabilized in light off conditions. In the other three vessels, $\mathrm{Fe}^{\mathrm{II}}$ concentrations remained stable until hour 14 when the concentrations increased (Figure 5-3). This increase in concentration occurred one hour prior to when the light was turned off.

In comparison to Cycle 1, the Fe(total) concentrations were larger and more stable during this experiment. Fe ${ }^{\mathrm{II}}$ concentrations were also above the MDL (Figure 5-2 and Table 5-3). The steady increase in $\mathrm{Fe}^{\mathrm{II}}$ concentrations for Vessel 2 in light on conditions indicates that $\mathrm{Fe}^{\mathrm{III}}$ 


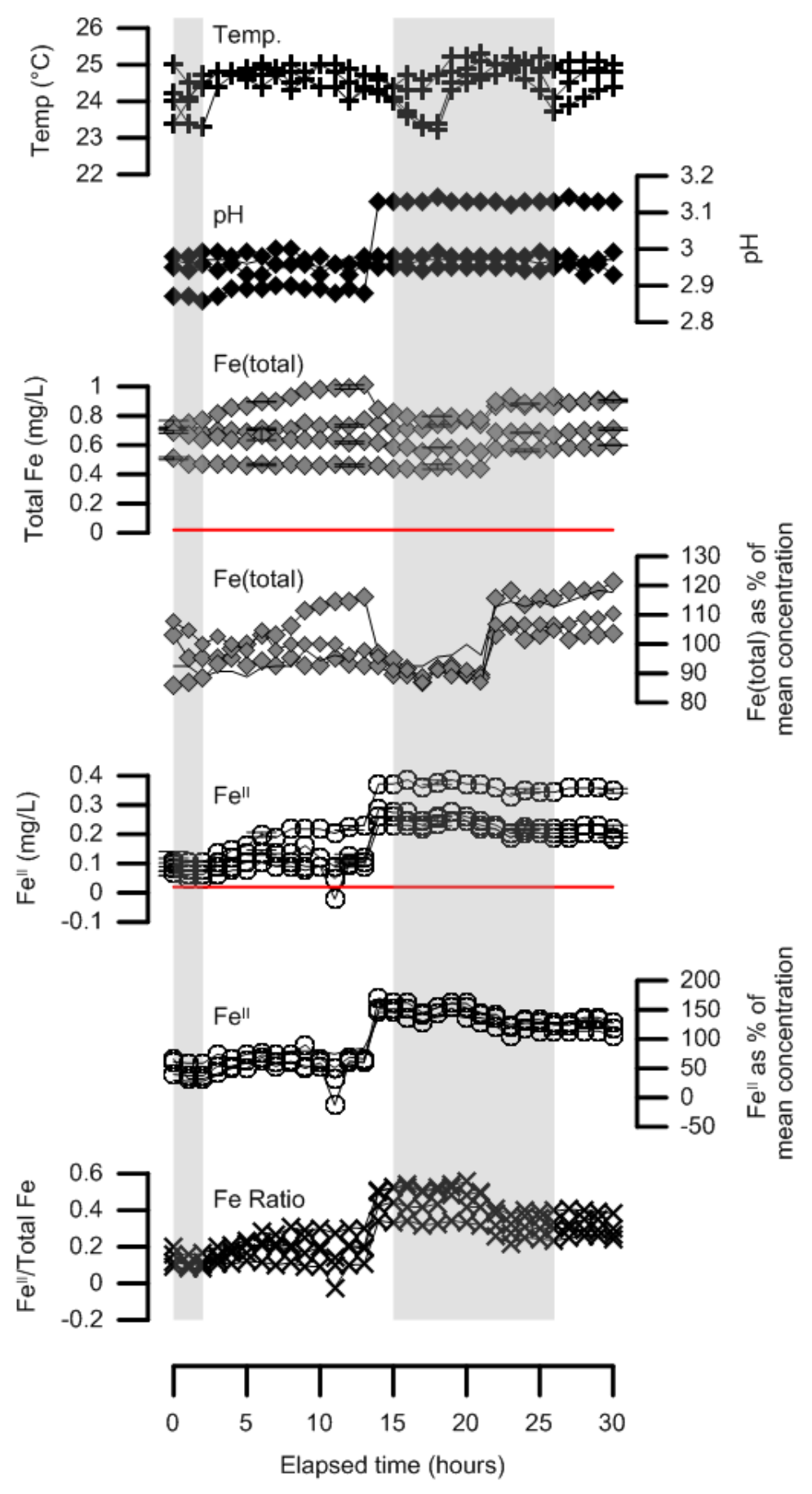

Figure 5-2. Cycle $2(10 / 17-18 / 2014)$ results with all vessels (V1-V4) graphed together. All vessels contained $\mathrm{Fe}$-only solutions. The solid red lines indicate the MDL for $\mathrm{Fe}^{\mathrm{II}}$ analysis $\left(0.02 \mathrm{mg} / \mathrm{L} \mathrm{Fe}{ }^{\mathrm{II}}\right)$ on the HACH DR2800 Spectrophotometer. Fe(total) is equal to the sum of $\mathrm{Fe}^{\mathrm{II}}$ and $\mathrm{Fe}^{\mathrm{III}}$ species. Standard deviations are represented by error bars for triplicate samples. The gray shaded areas indicate when the light was turned off (dark conditions). 

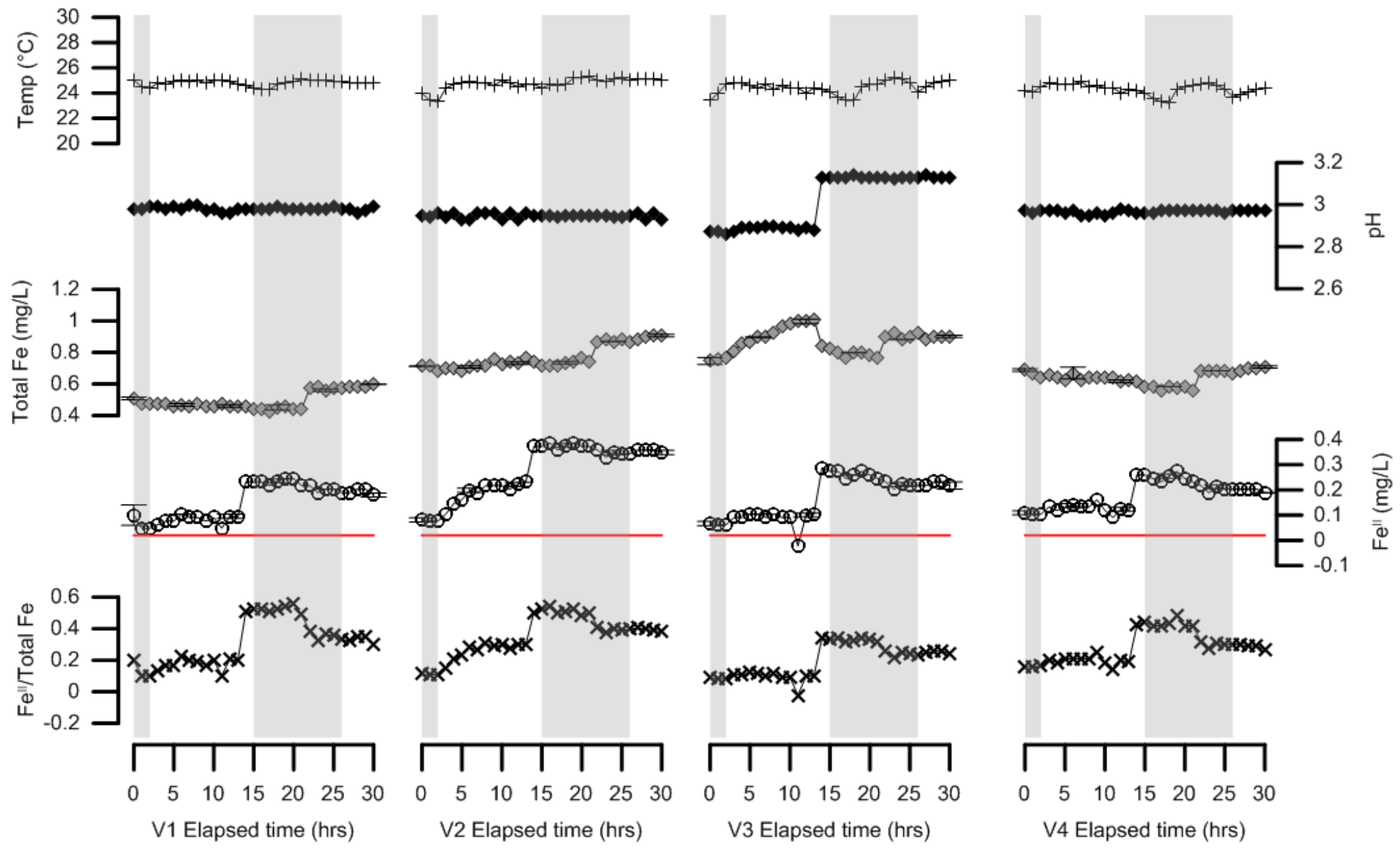

Figure 5-3. Cycle 2 (10/17-18/2014) results with all vessels (V1-V4) graphed separately. All vessels contained Fe-only solutions. The solid red lines indicate the MDL for $\mathrm{Fe}^{\mathrm{II}}$ analysis $\left(0.02 \mathrm{mg} / \mathrm{L} \mathrm{Fe}^{\mathrm{II}}\right)$ on the HACH DR2800 Spectrophotometer. $\mathrm{Fe}$ (total) is equal to the sum of $\mathrm{Fe}^{\mathrm{II}}$ and $\mathrm{Fe}^{\mathrm{III}}$ species. Standard deviations are represented by error bars for triplicate samples. The gray shaded areas indicate when the light was turned off (dark conditions). Note that the $\mathrm{pH}$ was adjusted in Vessel 3 during hour 13. 
Table 5-3. Cycle 2 (10/17-18/2014) parameter variability

\begin{tabular}{lcccccc}
\hline Parameter & Units & $\begin{array}{c}\text { Vessel } \\
\text { No. }\end{array}$ & Min. & Max. & $\begin{array}{c}\text { Range } \\
\text { (Min. - Max.) }\end{array}$ & Average \\
\hline Temperature & ${ }^{\circ} \mathrm{C}$ & 1 & 24.3 & 25.1 & 0.8 & 24.8 \\
& & 2 & 23.3 & 25.3 & 2.0 & 24.7 \\
& & 3 & 23.4 & 25.2 & 1.8 & 24.4 \\
& & 4 & 23.2 & 24.9 & 1.7 & 24.3 \\
\hline $\mathrm{pH}$ & --- & 1 & 2.96 & 3.00 & 0.04 & 2.98 \\
& & 2 & 2.93 & 2.96 & 0.03 & 2.95 \\
& & 3 & 2.86 & 3.14 & 0.28 & 3.02 \\
& & 4 & 2.95 & 2.98 & 0.03 & 2.97 \\
\hline $\mathrm{Fe}{ }^{I I}$ & $\mathrm{mg} / \mathrm{L}$ & 1 & 0.048 & 0.245 & 0.197 & 0.153 \\
& & 2 & 0.077 & 0.386 & 0.309 & 0.274 \\
& & 3 & $<0.02$ & 0.288 & 0.310 & 0.169 \\
& & 4 & 0.091 & 0.274 & 0.183 & 0.179 \\
\hline Fe(total) & $\mathrm{mg} / \mathrm{L}$ & 1 & 0.428 & 0.599 & 0.171 & 0.494 \\
& & 2 & 0.684 & 0.911 & 0.227 & 0.770 \\
& & 3 & 0.745 & 1.010 & 0.265 & 0.870 \\
& & 4 & 0.556 & 0.708 & 0.152 & 0.640 \\
\hline
\end{tabular}

Note: Min. is the minimum parameter value, and Max. is the maximum parameter value. 
photoreduction may have occurred; however, the steady increase in $\mathrm{Fe}^{\mathrm{II}}$ concentrations with the light on was not observed in Vessels 1, 3, and 4 (Figure 5-3). In these three vessels, the Fe ${ }^{\text {II }}$ concentrations abruptly increased around hour 14 (one hour before the light was turned off). This increase in $\mathrm{Fe}^{\mathrm{II}}$ concentration did not correlate with changes in $\mathrm{pH}$ or temperature. This suggests that light on/off conditions were driving $\mathrm{Fe}^{\mathrm{II}}$ concentration changes. For Vessel 3, the decrease in $\mathrm{Fe}($ total) concentrations was likely due to $\mathrm{HFO}$ precipitation with increasing $\mathrm{pH}$ and decreasing temperature (Figure 5-3, V3). A combination of temperature and solution $\mathrm{pH}$ was the likely cause of Fe(total) concentration changes in this experiment.

\subsection{Cycle 3: 10/25/2014}

A 10-hour Fe-Se combined temperature cycle was conducted on October 25, 2014 (Table 5-1). The purpose of this experiment was to determine if Fe and Se concentration changes could be detected with increasing and decreasing temperature. In order to determine if temperature alone could drive Fe and Se cycles, this experiment was completed in the dark to eliminate the effects of $\mathrm{Fe}^{\mathrm{III}}$ photoreduction.

Four reaction vessels containing Fe-Se solutions (Table 4-1) were prepared for this experiment. Each vessel contained $3000 \mu \mathrm{g} / \mathrm{L} \mathrm{Se}^{\mathrm{IV}}$. A full temperature cycle was not completed. Sampling was completed for one temperature increasing series and one temperature decreasing series (Figures 5-4 and 5-5). Fe(total) and $\mathrm{Fe}^{\mathrm{II}}$ concentrations decreased slightly throughout the experiment, but were not directly linked to changes in temperature or $\mathrm{pH}$. $\mathrm{Se}^{\mathrm{IV}}$ concentrations cycled with temperature (Figures 5-4 and 5-5, Table 5-4).

A direct correlation between Fe concentrations and temperature was not observed. However, $\mathrm{Se}^{\mathrm{IV}}$ cycled directly with temperature, and hysteresis was observed (Figure 5-6, Table 5-5). It is likely that $\mathrm{Se}^{\mathrm{IV}}$ concentrations cycled due to temperature-dependent sorption of $\mathrm{Se}^{\mathrm{IV}}$ onto 2-line ferrihydrite. The $\log$ of $\mathrm{Se}^{\mathrm{IV}}$ concentrations (molar) was plotted versus 1/temperature (in Kelvin) to solve for enthalpy of sorption values in kJ/mol (Eq. 5, Figure 5-7, Table 5-6). 


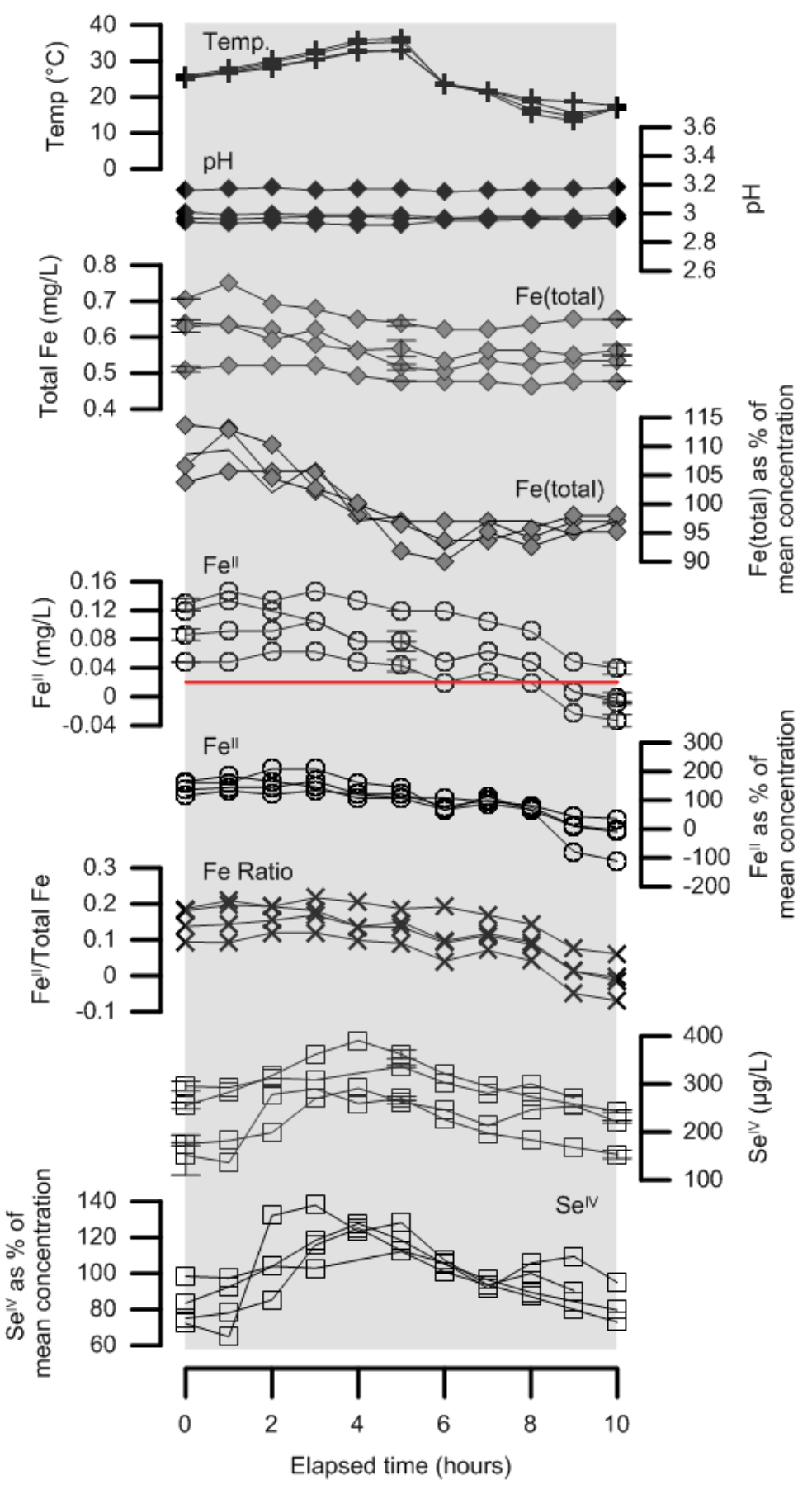

Figure 5-4. Cycle 3 (10/25/2014) results with all vessels (V1-V4) graphed together. All vessels contained Fe-Se solutions. The solid red line indicates the MDL for Fe ${ }^{\mathrm{II}}$ analysis $\left(0.02 \mathrm{mg} / \mathrm{L} \mathrm{Fe}^{\mathrm{II}}\right)$ on the HACH DR2800 Spectrophotometer. Fe(total) is equal to the sum of $\mathrm{Fe}^{\mathrm{II}}$ and $\mathrm{Fe}^{\mathrm{III}}$ species. Standard deviations are represented by error bars for triplicate samples. The gray shaded area indicates that the light was turned off for this experiment (dark conditions). 


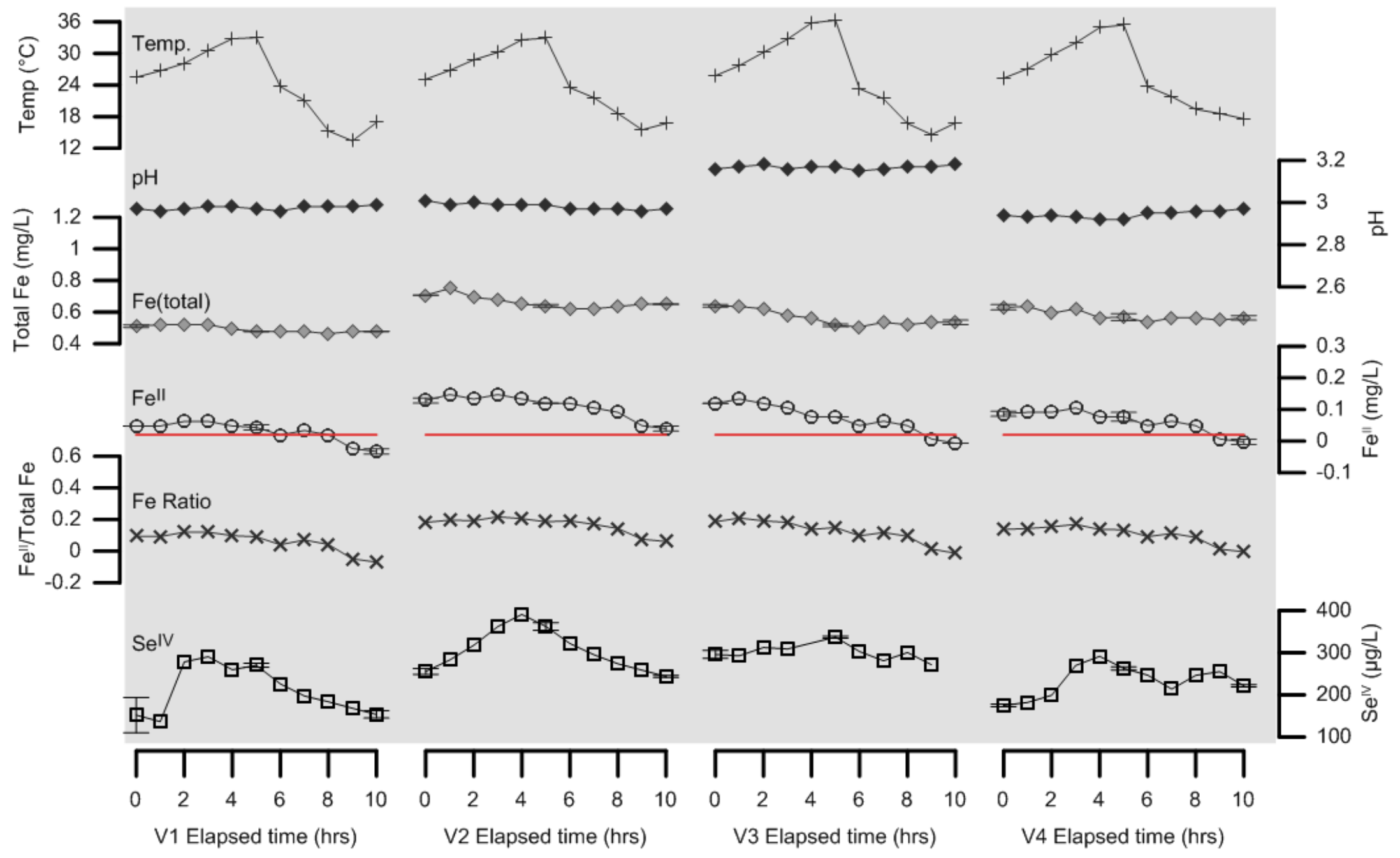

Figure 5-5. Cycle 3 (10/25/2014) results with all vessels (V1-V4) graphed separately. All vessels contained Fe-Se solutions. The solid red lines indicate the MDL for Fe ${ }^{\mathrm{II}}$ analysis $\left(0.02 \mathrm{mg} / \mathrm{L} \mathrm{Fe}^{\mathrm{II}}\right)$ on the HACH DR2800 Spectrophotometer. Fe(total) is equal to the sum of $\mathrm{Fe}^{\mathrm{II}}$ and $\mathrm{Fe}^{\mathrm{III}}$ species. Standard deviations are represented by error bars for triplicate samples. The gray shaded area indicates that the light was turned off for this experiment (dark conditions). 
Table 5-4. Cycle 3 (10/25/2014) parameter variability

\begin{tabular}{|c|c|c|c|c|c|c|}
\hline Parameter & Units & $\begin{array}{c}\text { Vessel } \\
\text { No. } \\
\end{array}$ & Min. & Max. & $\begin{array}{c}\text { Range } \\
\text { (Min. - Max.) } \\
\end{array}$ & Average \\
\hline \multirow[t]{4}{*}{ Temperature } & ${ }^{\circ} \mathrm{C}$ & 1 & 13.4 & 33.0 & 19.6 & 24.3 \\
\hline & & 2 & 15.5 & 32.9 & 17.4 & 24.8 \\
\hline & & 3 & 14.6 & 36.3 & 21.7 & 25.6 \\
\hline & & 4 & 17.6 & 35.4 & 17.8 & 26.0 \\
\hline \multirow[t]{4}{*}{$\mathrm{pH}$} & --- & 1 & 2.96 & 2.99 & 0.03 & 2.97 \\
\hline & & 2 & 2.96 & 3.01 & 0.05 & 2.98 \\
\hline & & 3 & 3.15 & 3.18 & 0.03 & 3.17 \\
\hline & & 4 & 2.92 & 2.97 & 0.05 & 2.94 \\
\hline \multirow[t]{4}{*}{$\mathrm{Fe}^{\mathrm{II}}$} & $\mathrm{mg} / \mathrm{L}$ & 1 & $<0.02$ & 0.062 & 0.095 & 0.030 \\
\hline & & 2 & 0.040 & 0.147 & 0.107 & 0.110 \\
\hline & & 3 & $<0.02$ & 0.133 & 0.140 & 0.072 \\
\hline & & 4 & $<0.02$ & 0.105 & 0.108 & 0.063 \\
\hline \multirow[t]{4}{*}{$\mathrm{Fe}$ (total) } & $\mathrm{mg} / \mathrm{L}$ & 1 & 0.464 & 0.521 & 0.057 & 0.493 \\
\hline & & 2 & 0.621 & 0.750 & 0.129 & 0.663 \\
\hline & & 3 & 0.507 & 0.640 & 0.133 & 0.563 \\
\hline & & 4 & 0.535 & 0.636 & 0.101 & 0.581 \\
\hline \multirow[t]{4}{*}{$\mathrm{Se}^{\mathrm{IV}}$} & $\mu \mathrm{g} / \mathrm{L}$ & 1 & 136.4 & 290.4 & 154.0 & 210.4 \\
\hline & & 2 & 243.5 & 390.8 & 147.3 & 305.8 \\
\hline & & 3 & 271.4 & 337.0 & 65.6 & 300.2 \\
\hline & & 4 & 174.9 & 291.5 & 116.6 & 227.7 \\
\hline
\end{tabular}

Note: Min. is the minimum parameter value, and Max. is the maximum parameter value. 


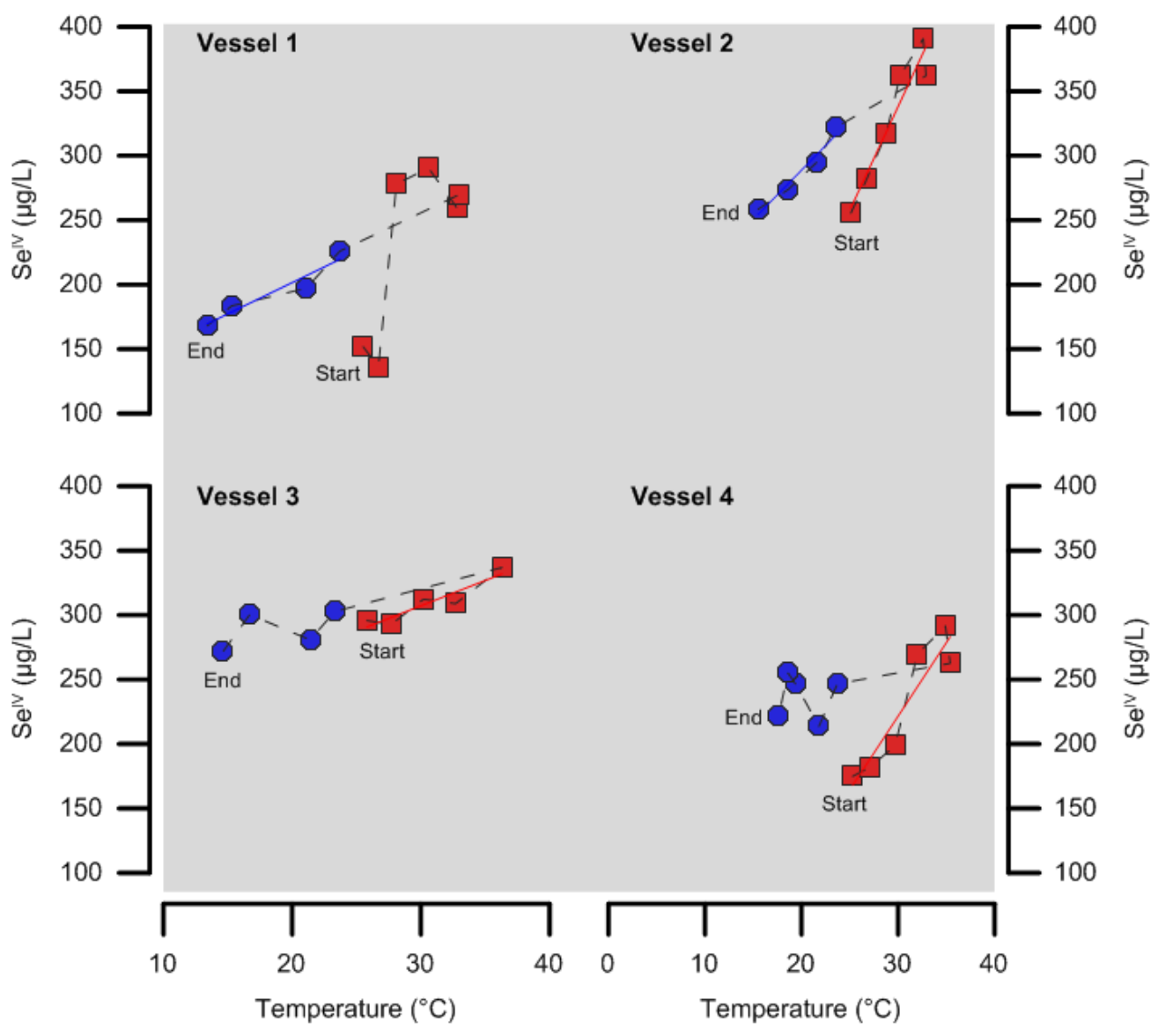

Figure 5-6. Cycle 3 (10/25/2014) relationship between $\mathrm{Se}^{\mathrm{IV}}$ concentrations and temperature. The start and end of each cycle is labeled next to the corresponding data symbol (red square). Red squares represent the temperature increasing series, whereas the blue circles represent the temperature decreasing series. Solid red lines are linear regression lines for the temperature increasing series. Solid blue lines are linear regression lines for the temperature decreasing series. The black dashed lines indicate the order in which samples were collected over time. The gray shaded area indicates that the light was turned off for this experiment (dark conditions). 
Table 5-5. Se $\mathrm{IV}^{\mathrm{IV}}$ versus temperature linear regression results

\begin{tabular}{|c|c|c|c|c|c|c|}
\hline $\begin{array}{l}\text { Cycle } \\
\text { No. }\end{array}$ & $\begin{array}{l}\text { Vessel } \\
\text { No. }\end{array}$ & $\begin{array}{c}\text { Temperature } \\
\text { (increase or decrease) }\end{array}$ & $\mathbf{n}$ & $\overline{\mathbf{R}^{2}}$ & Slope & Intercept \\
\hline \multirow{8}{*}{3} & 1 & increase & 6 & 0.564 & 16.18 & -245.5 \\
\hline & 2 & increase & 6 & 0.921 & 16.07 & -144.0 \\
\hline & 3 & increase & 5 & 0.855 & 3.920 & 189.6 \\
\hline & 4 & increase & 6 & 0.865 & 11.41 & -120.8 \\
\hline & 1 & decrease & 4 & 0.911 & 4.862 & 104.4 \\
\hline & 2 & decrease & 4 & 0.951 & 7.647 & 135.9 \\
\hline & 3 & decrease & 4 & 0.243 & 1.858 & 253.5 \\
\hline & 4 & decrease & 5 & $1.40 \times 10^{-5}$ & 0.027 & 236.0 \\
\hline \multirow{6}{*}{4} & 3 & increase 1 & 3 & 0.810 & -0.323 & 20.91 \\
\hline & 4 & increase 1 & 4 & 0.859 & 2.417 & -19.42 \\
\hline & 3 & decrease & 6 & 0.219 & -0.049 & 13.51 \\
\hline & 4 & decrease & 6 & 0.916 & 1.974 & 25.28 \\
\hline & 3 & increase 2 & 6 & 0.602 & -0.178 & 15.62 \\
\hline & 4 & increase 2 & 6 & 0.234 & -0.081 & 37.74 \\
\hline \multirow{6}{*}{6} & 3 & increase 1 & 4 & 0.811 & 2.499 & -19.01 \\
\hline & 4 & increase 1 & 4 & 0.647 & -1.129 & 72.07 \\
\hline & 3 & decrease & 6 & 0.819 & 0.684 & 35.83 \\
\hline & 4 & decrease & 6 & 0.793 & 0.442 & 26.31 \\
\hline & 3 & increase 2 & 6 & 0.035 & -0.001 & 0.479 \\
\hline & 4 & increase 2 & 6 & 0.315 & 0.490 & 32.20 \\
\hline \multirow{12}{*}{7} & 1 & increase 1 & 3 & 0.822 & 2.396 & 286.0 \\
\hline & 2 & increase 1 & 3 & 0.211 & 0.437 & 347.0 \\
\hline & 3 & increase 1 & 3 & 0.523 & 1.552 & 323.0 \\
\hline & 4 & increase 1 & 3 & 0.785 & 1.021 & 353.8 \\
\hline & 1 & decrease & 6 & 0.861 & 0.769 & 342.1 \\
\hline & 2 & decrease & 6 & 0.827 & 0.911 & 337.6 \\
\hline & 3 & decrease & 6 & 0.811 & 1.149 & 346.1 \\
\hline & 4 & decrease & 6 & 0.413 & 0.566 & 369.6 \\
\hline & 1 & increase 2 & 6 & 0.566 & 0.673 & 352.7 \\
\hline & 2 & increase 2 & 6 & 0.513 & 0.682 & 349.8 \\
\hline & 3 & increase 2 & 6 & 0.742 & 0.641 & 360.1 \\
\hline & 4 & increase 2 & 6 & 0.867 & 1.117 & 360.6 \\
\hline
\end{tabular}

Note: $\mathrm{n}$ is the number of data points. $\mathrm{R}^{2}$ is the coefficient of determination. Refer to Figures 5-6, 5-10, 5-16, and 5-20. Linear regression results were calculated using the Data Analysis ToolPak in Microsoft Excel. A separate linear regression was completed for each color coded series (increasing temperature 1, decreasing temperature, and increasing temperature 2) in the figures mentioned above. The linear results were graphed for $\mathrm{R}^{2}$ values greater than 0.7 . 


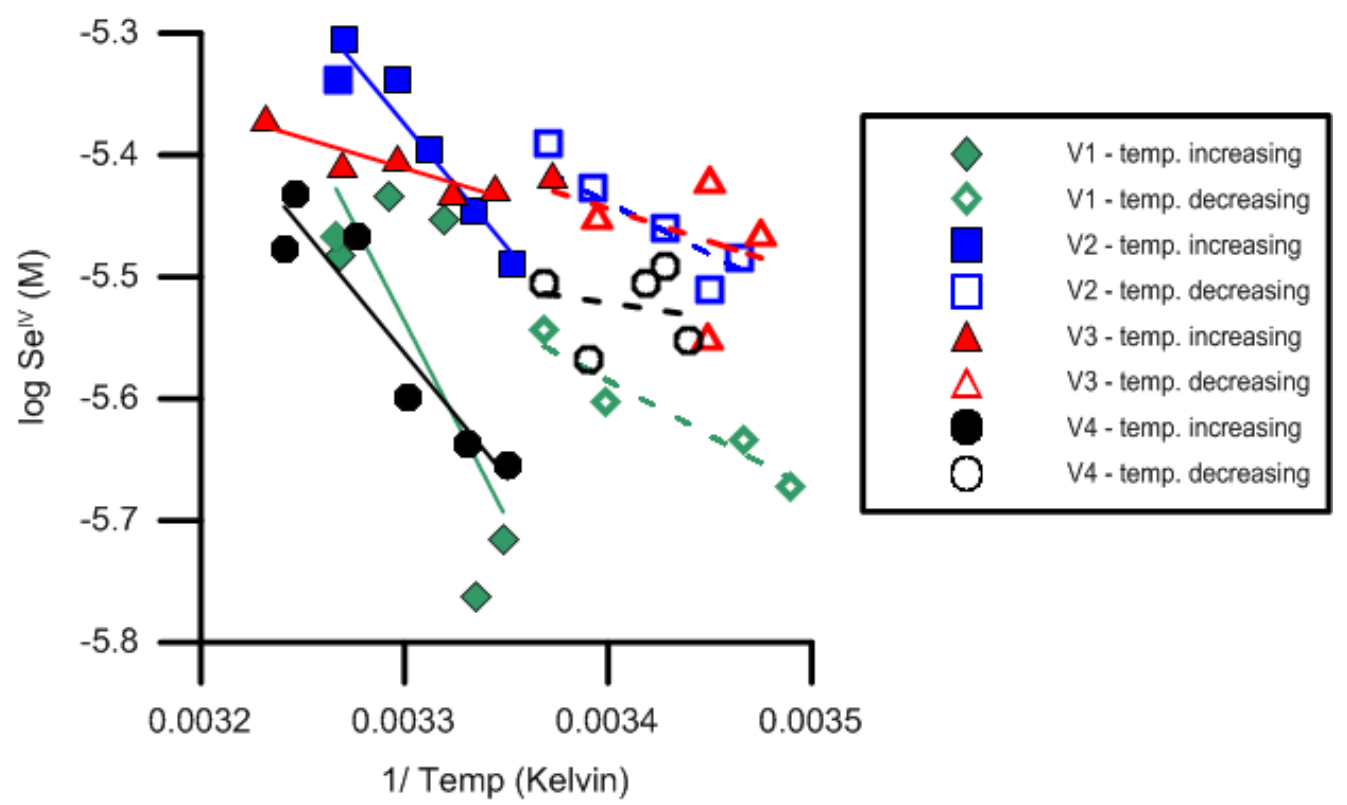

Figure 5-7. Enthalpy of sorption plot for Cycle 3 (10/25/2014). Increasing temperature series (solid symbols and lines) and decreasing temperature series (open symbols and dashed lines) data are plotted separately for each vessel. Vessel numbers are labelled V1 through V4. 
Table 5-6. Conditional Enthalpies of Sorption for Cycle 3

\begin{tabular}{lccccc}
\hline $\begin{array}{l}\text { Temperature } \\
\text { (increase/decrease) }\end{array}$ & $\begin{array}{c}\text { Vessel } \\
\text { No. }\end{array}$ & $\mathbf{R}^{2}$ & slope & $\mathbf{n}$ & $\begin{array}{c}\text { Enthalpy } \\
\text { (kJ/ mol) }\end{array}$ \\
\hline Increase & 1 & 0.585 & -3232 & 6 & -61.9 \\
Increase & 2 & 0.926 & -2011 & 6 & -38.5 \\
Increase & 3 & 0.854 & -500.6 & 5 & -9.58 \\
Increase & 4 & 0.883 & -2036 & 6 & -39.0 \\
\hline Decrease & 1 & 0.973 & -899.5 & 5 & -17.2 \\
Decrease & 2 & 0.915 & -849.2 & 5 & -16.3 \\
Decrease & 3 & 0.183 & -536.7 & 5 & -10.3 \\
Decrease & 4 & 0.251 & -242.1 & 5 & -4.64 \\
\hline
\end{tabular}

Note: $\mathrm{R}^{2}$ is the coefficient of determination. $\mathrm{n}$ is the number of data points. 


\subsection{Cycle 4: 12/09/2014}

Two experiments, a 10-hour Fe-only temperature cycle and a 10-hour Fe-Se combined temperature cycle, were conducted on December 9, 2014 (Table 5-1). The purpose of these experiments was to determine if Fe and Se concentration changes could be detected with increasing and decreasing temperature. Two vessels were prepared with Fe-only solution (Vessels 1 and 2) (Table 4-1). The other two vessels were prepared with Fe-Se solution (Vessels 3 and 4) (Table 4-1) to compare to the Cycle 3 (10/25/2014) results. The light remained on during these experiments to allow for $\mathrm{Fe}^{\mathrm{III}}$ photoreduction. A full temperature cycle was completed for this experiment (temperature increase, temperature decrease, then a second temperature increase) (Figures 5-8 and 5-9).

The average light intensity was 3563 Lux. Fe ${ }^{\text {II }}$ cycled with temperature in both the Feonly and Fe-Se combined experiments with a slight lag (Figures 5-8 and 5-9). Fe ${ }^{\mathrm{II}}$ concentrations were larger in comparison with the previous dark (light off) cycle (Cycle 3). These larger Fe concentrations were likely the result of $\mathrm{Fe}^{\mathrm{III}}$ photoreduction during light on conditions. Fe(total) concentrations remained relatively stable throughout the experiment (Figures 5-8 and 5-9, Table 5-7). $\mathrm{Se}^{\mathrm{IV}}$ cycled with temperature in one of the two Fe-Se combined experiment vessels (Vessel 4) (Figures 5-8 and 5-9, Table 5-7).

Hysteresis was observed between temperature and $\mathrm{Se}^{\mathrm{IV}}$ concentrations in Vessel 4 but was not observed in Vessel 3 (Figure 5-10, Table 5-5). The pH of Vessel 3 was likely too high for $\mathrm{Se}^{\mathrm{IV}}$ cycling to occur (Table 5-7). In comparison, the $\mathrm{pH}$ of the other three vessels was less than 2.98. The $\log$ of $\mathrm{Se}^{\mathrm{IV}}$ concentrations (molar) was plotted versus $1 /$ temperature (in Kelvin) to solve for enthalpy of sorption values in kJ/mol (Eq. 5, Figure 5-11, Table 5-8).

\subsection{Cycle 5: 1/29/2015}

A 3.5 hour Se-only partial temperature cycle was completed on January 29, 2015 (Table 5-1). Sampling was completed for one temperature increasing series and one temperature decreasing series (Figures 5-12 and 5-13). The purpose of this experiment was to determine if Se 

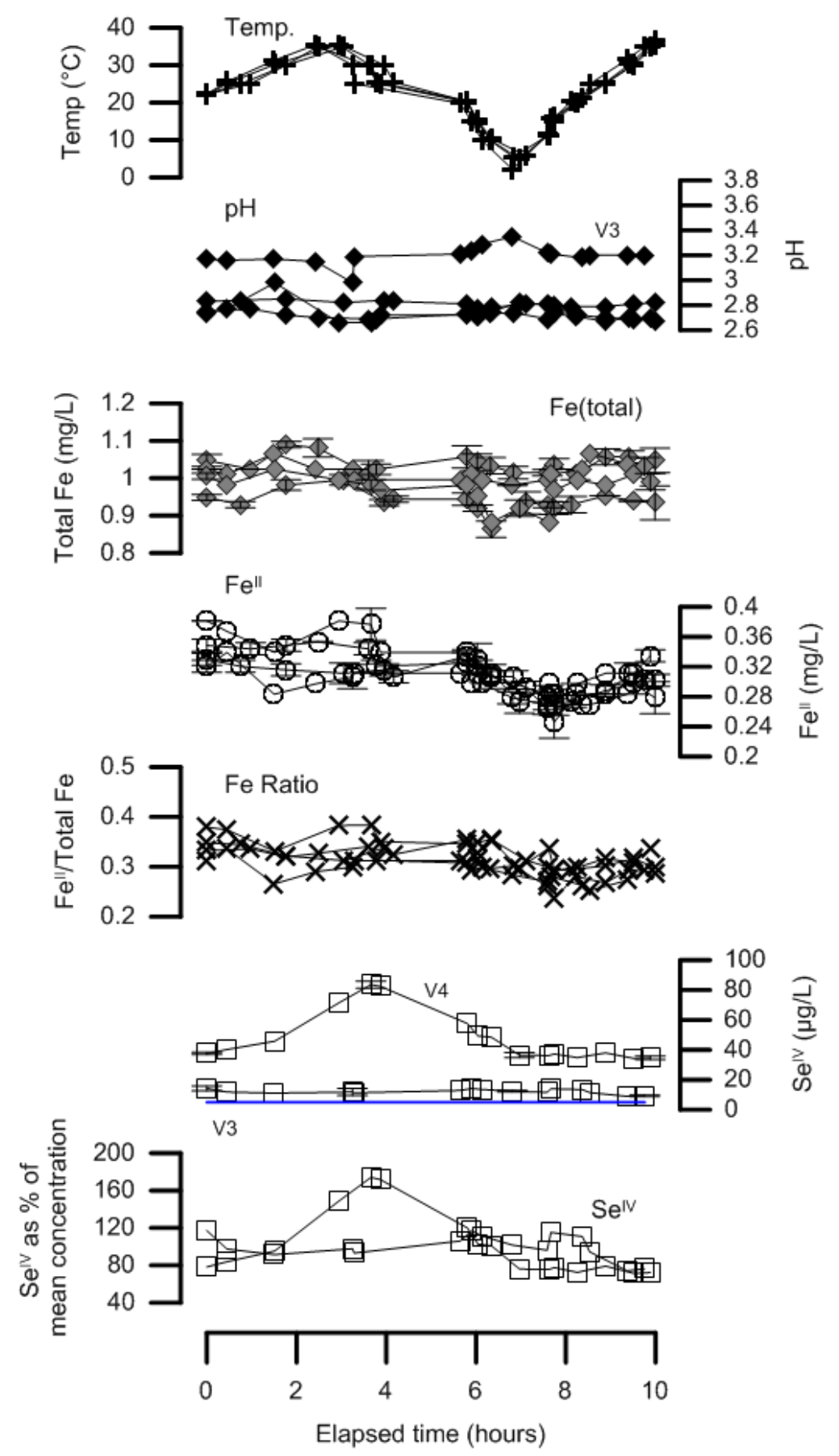

Figure 5-8. Cycle 4 (12/09/2014) results with all vessels (V1-V4) graphed together. Vessels 1 and 2 contained Fe-only solutions, whereas Vessels 3 and 4 contained $\mathrm{Fe}-\mathrm{Se}$ solutions. The solid blue lines indicate the MDL for $\mathrm{Se}^{\mathrm{IV}}$ analysis $\left(5 \mu \mathrm{g} / \mathrm{L} \mathrm{Se}^{\mathrm{IV}}\right)$ on the Perkin Elmer Optima 2100 DV ICP-OES. Standard deviations are represented by error bars for triplicate samples. 

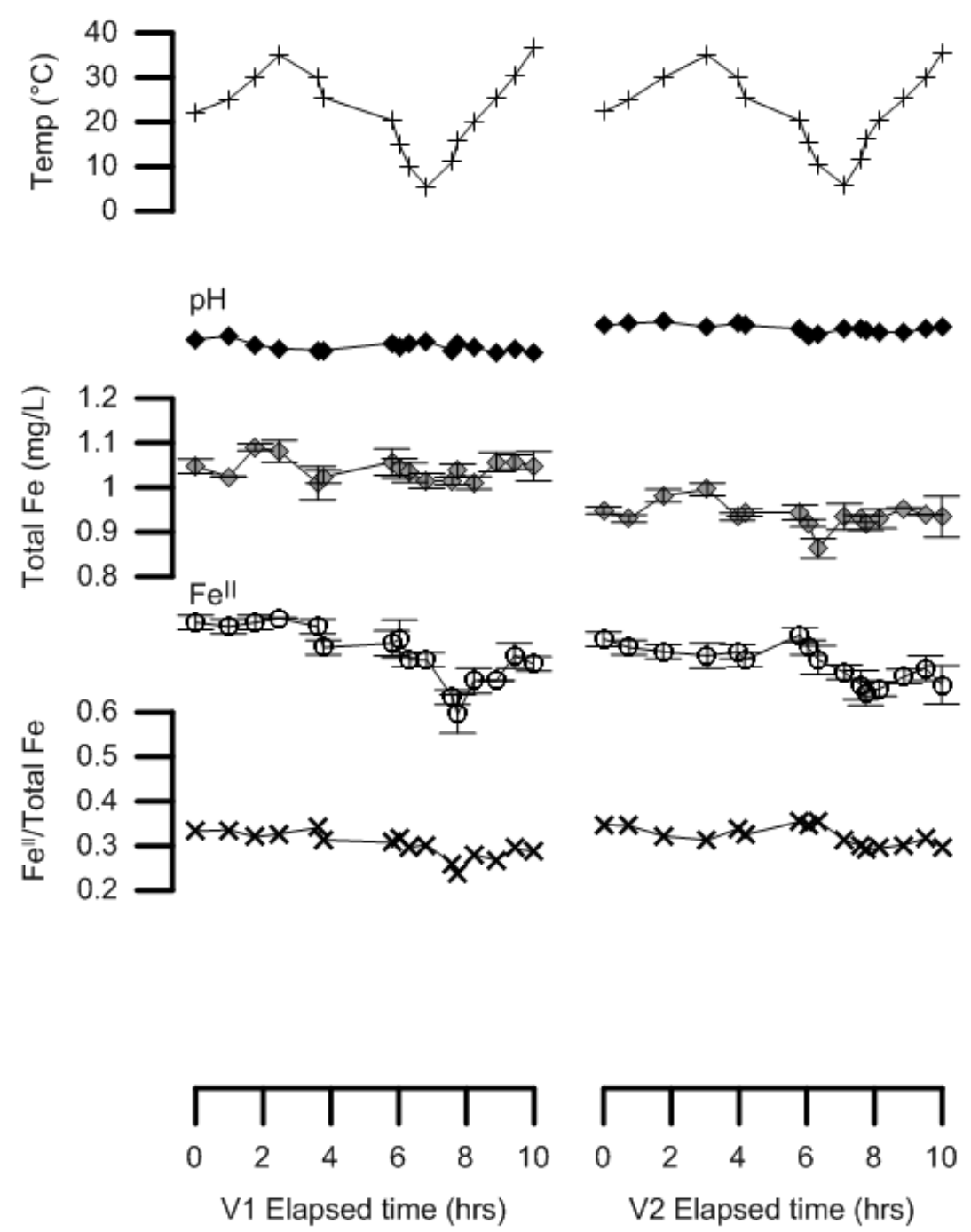
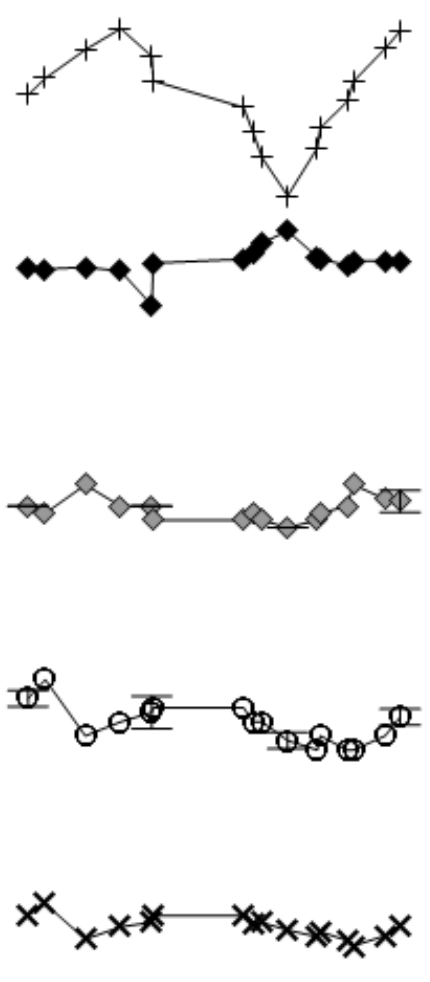

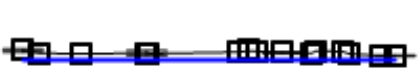
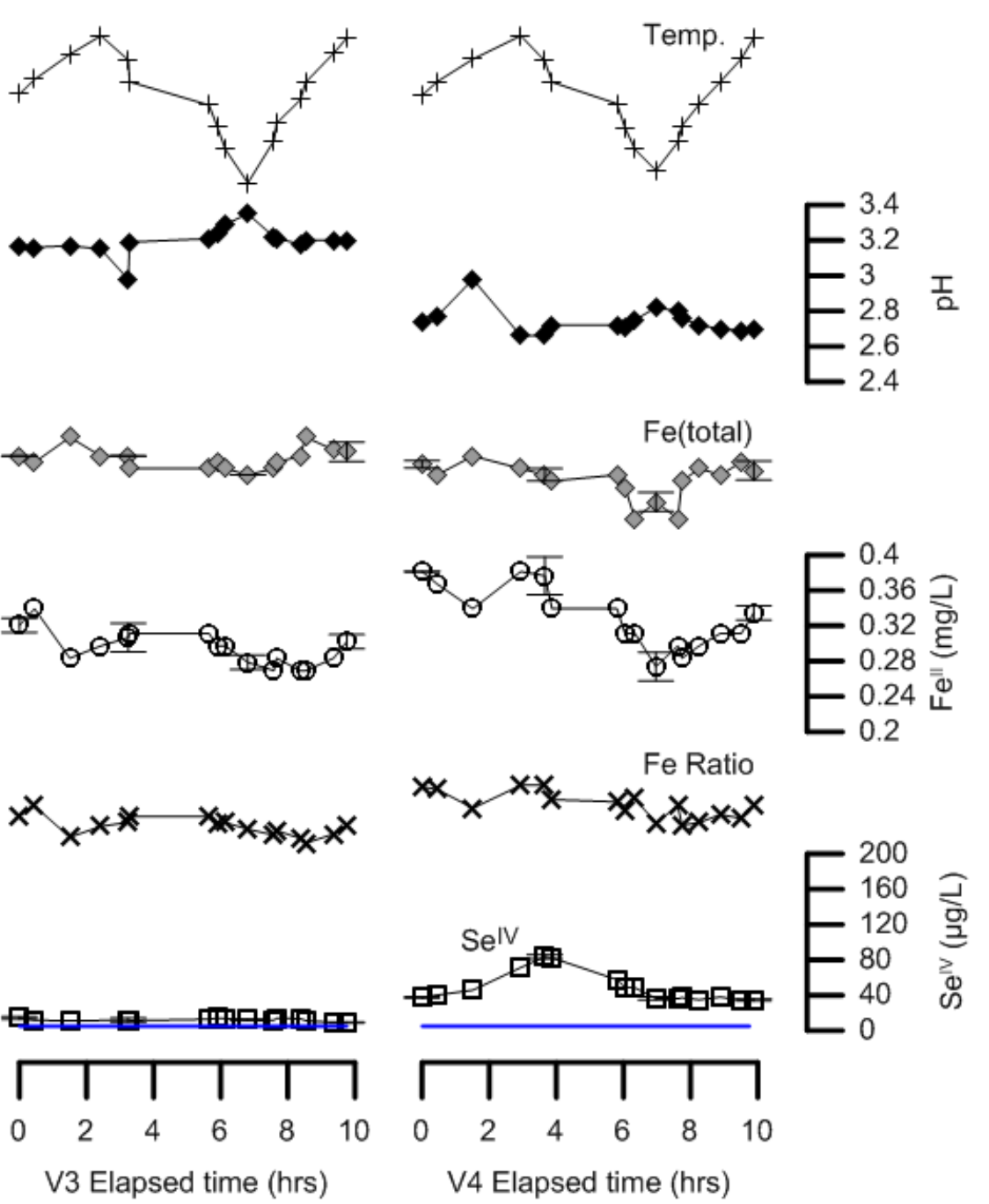

Figure 5-9. Cycle 4 (12/09/2014) results with all vessels (V1-V4) graphed separately. Vessels 1 and 2 contained Fe-only solutions, whereas Vessels 3 and 4 contained Fe-Se solutions. The solid blue lines indicate the MDL for $\mathrm{Se}^{\mathrm{IV}}$ analysis $(5 \mu \mathrm{g} / \mathrm{L}$ $\mathrm{Se}^{\mathrm{IV}}$ ) on the Perkin Elmer Optima 2100 DV ICP-OES. Standard deviations are represented by error bars for triplicate samples. 
Table 5-7. Cycle 4 (12/9/2014) parameter variability

\begin{tabular}{lcccccc}
\hline Parameter & Units & $\begin{array}{c}\text { Vessel } \\
\text { No. }\end{array}$ & Min. & Max. & $\begin{array}{c}\text { Range } \\
\text { (Min. - Max.) }\end{array}$ & Average \\
\hline Temperature & ${ }^{\circ} \mathrm{C}$ & 1 & 5.5 & 36.5 & 31.0 & 22.3 \\
& & 2 & 5.8 & 35.4 & 29.6 & 22.4 \\
& & 3 & 2.2 & 35.5 & 33.3 & 22.3 \\
& & 4 & 5.0 & 35.5 & 30.5 & 22.1 \\
\hline $\mathrm{pH}$ & --- & 1 & 2.67 & 2.77 & 0.10 & 2.71 \\
& & 2 & 2.77 & 2.85 & 0.08 & 2.81 \\
& & 3 & 2.98 & 3.35 & 0.37 & 3.20 \\
& & 4 & 2.66 & 2.98 & 0.32 & 2.74 \\
\hline $\mathrm{Fe}^{\mathrm{II}}$ & $\mathrm{mg} / \mathrm{L}$ & 1 & 0.246 & 0.353 & 0.107 & 0.314 \\
& & 2 & 0.269 & 0.335 & 0.066 & 0.303 \\
& & 3 & 0.269 & 0.339 & 0.070 & 0.295 \\
& & 4 & 0.274 & 0.381 & 0.107 & 0.328 \\
\hline $\mathrm{Fe}($ total) & $\mathrm{mg} / \mathrm{L}$ & 1 & 1.010 & 1.090 & 0.080 & 1.041 \\
& & 2 & 0.864 & 0.996 & 0.132 & 0.938 \\
& & 3 & 0.982 & 1.067 & 0.085 & 1.019 \\
& & 4 & 0.882 & 1.024 & 0.142 & 0.970 \\
\hline $\mathrm{Se}^{\mathrm{IV}}$ & $\mu \mathrm{g} / \mathrm{L}$ & 3 & 9.0 & 14.2 & 5.2 & 12.1 \\
& & 4 & 34.3 & 83.5 & 49.2 & 48.0 \\
\hline
\end{tabular}

Note: Min. is the minimum parameter value, and Max. is the maximum parameter value. 

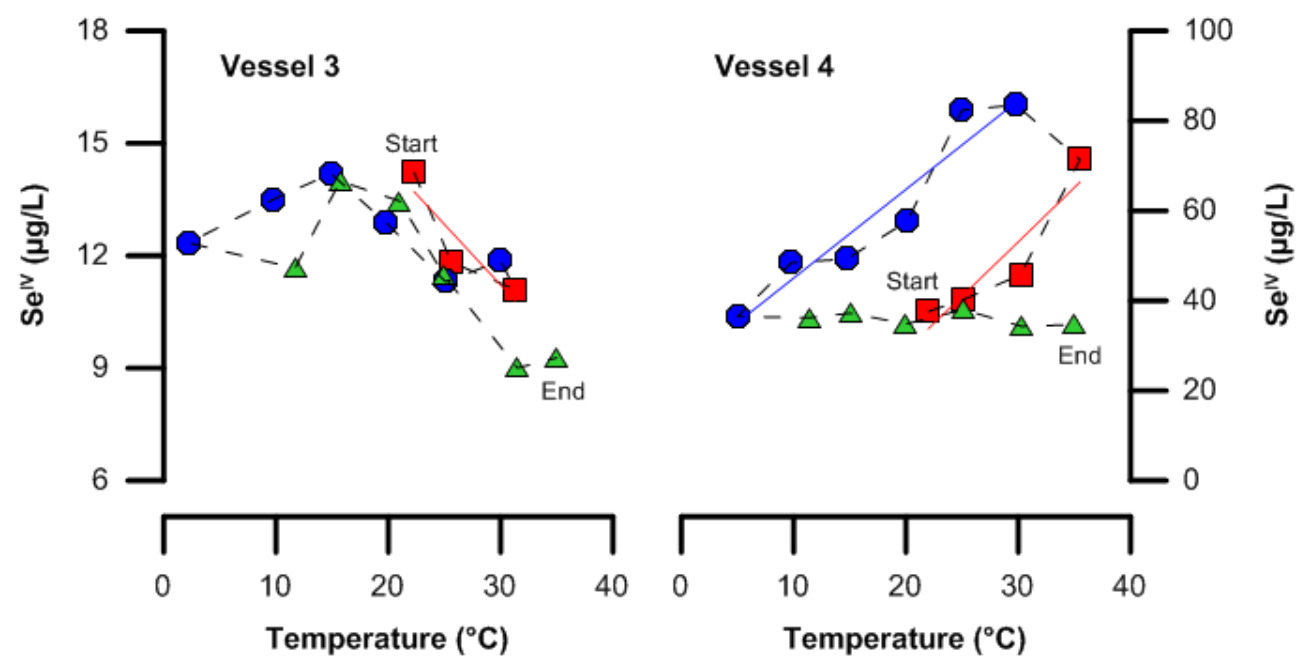

Figure 5-10. Cycle 4 (12/9/2014) relationship between $\mathrm{Se}^{\mathrm{IV}}$ concentrations and temperature. The start and end of each cycle is labeled next to the corresponding data symbol (red square). Red squares represent the first temperature increasing series, blue circles represent the temperature decreasing series, and green triangles represent the second temperature increasing series. Solid red lines are linear regression lines for the first temperature increasing series. Solid blue lines are linear regression lines for the temperature decreasing series. The black dashed lines indicate the order in which samples were collected over time. 


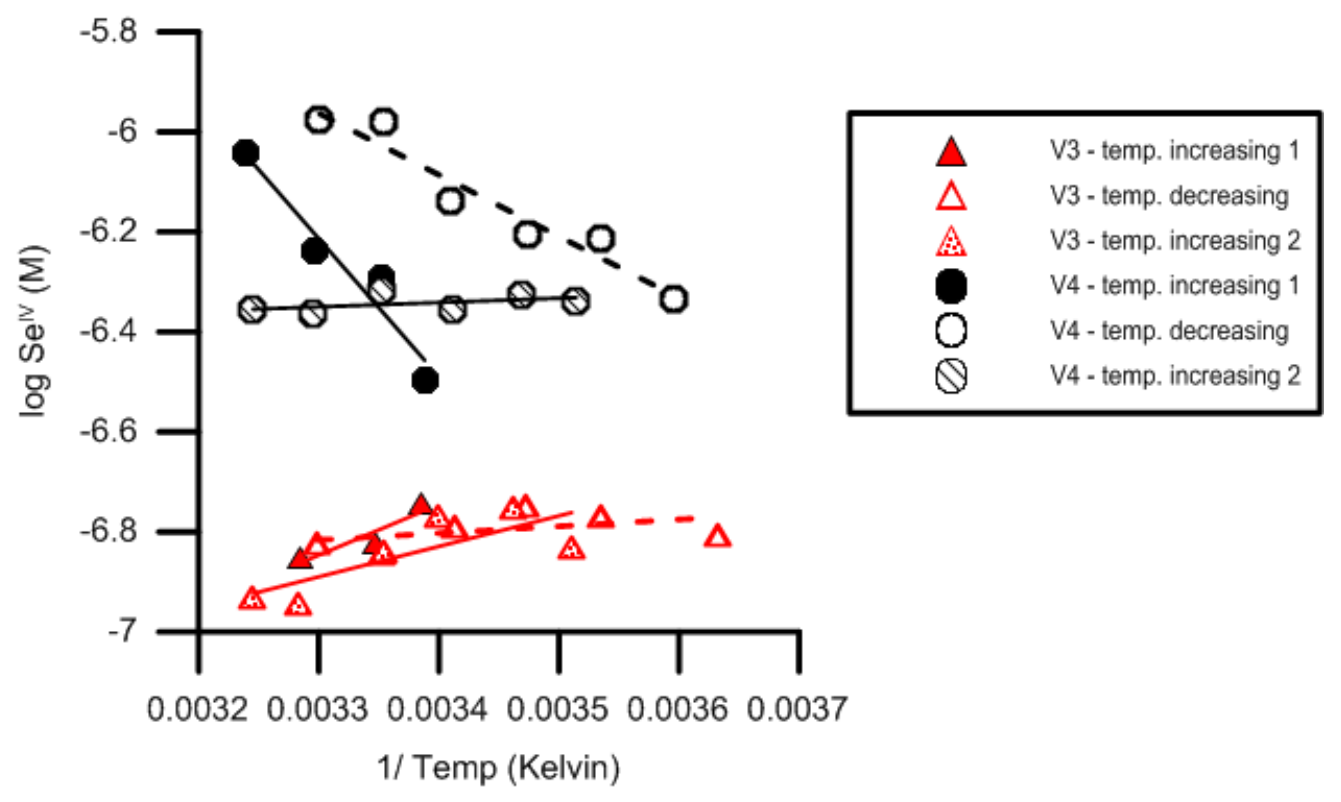

Figure 5-11. Enthalpy of sorption plot for Cycle 4 (12/9/2014). The increasing temperature series 1 (solid symbols and solid lines), decreasing temperature series (open symbols and dashed lines), and increasing temperature series 2 (patterned symbols and solid lines) data are plotted separately for each vessel. Vessel numbers are labelled V3 and V4. 
Table 5-8. Conditional Enthalpies of Sorption for Cycle 4

\begin{tabular}{lccccc}
\hline $\begin{array}{l}\text { Temperature } \\
\text { (increase/decrease) }\end{array}$ & $\begin{array}{c}\text { Vessel } \\
\text { No. }\end{array}$ & $\mathbf{R}^{2}$ & slope & $\mathbf{n}$ & $\begin{array}{c}\text { Enthalpy } \\
(\mathbf{k J} / \mathbf{m o l})\end{array}$ \\
\hline Increase 1 & 3 & 0.835 & -1011 & 3 & 19.4 \\
Increase 1 & 4 & 0.932 & -2758 & 4 & -52.8 \\
\hline Decrease & 3 & 0.212 & 137.4 & 6 & 2.63 \\
Decrease & 4 & 0.937 & -1231 & 6 & -23.6 \\
\hline Increase 2 & 3 & 0.615 & 609.6 & 6 & 11.7 \\
Increase 2 & 4 & 0.237 & -86.45 & 6 & 1.66 \\
\hline
\end{tabular}

Note: $\mathrm{R}^{2}$ is the coefficient of determination. $\mathrm{n}$ is the number of data points. An outlying data point was removed from the temperature increase 1 series calculation for Vessel 3. 

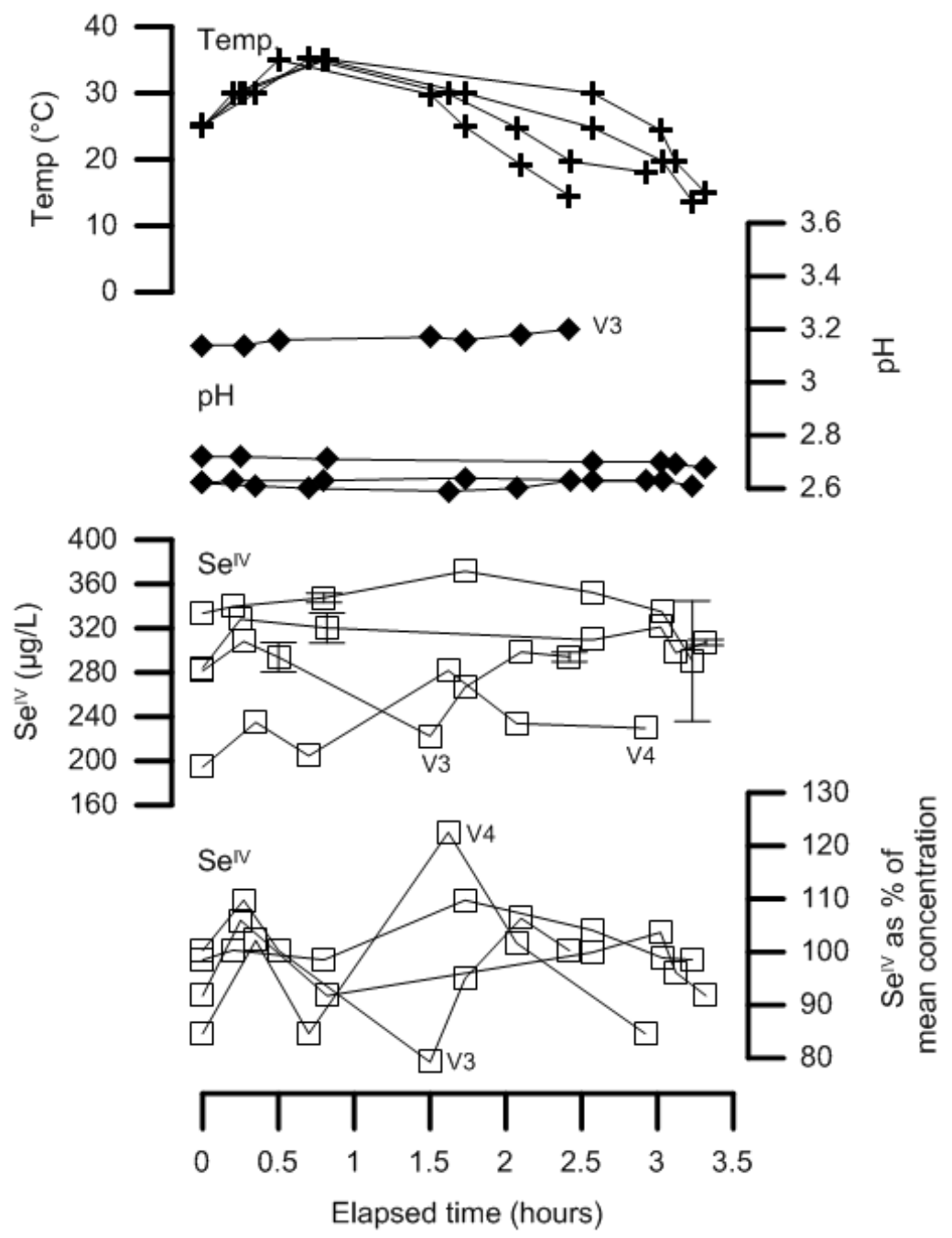

Figure 5-12. Cycle 5 (1/29/2015) results with all vessels (V1-V4) graphed together. All vessels contained Se-only solutions. Standard deviations are represented by error bars for triplicate samples. 


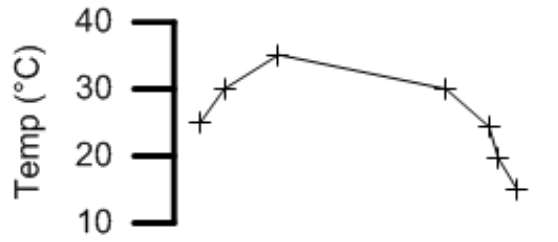

$\mathrm{pH}$

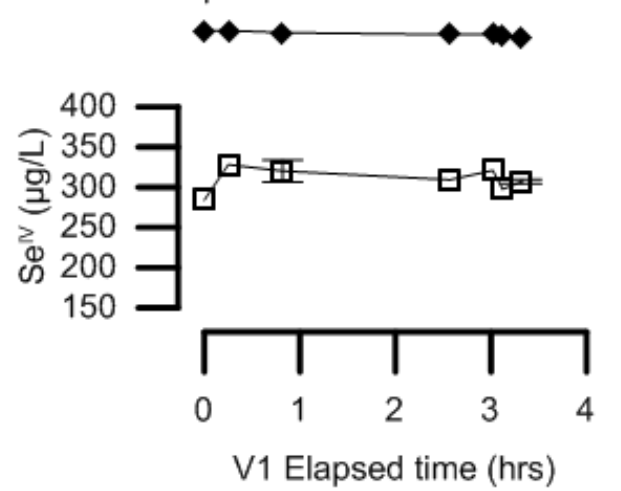

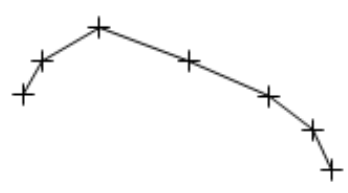

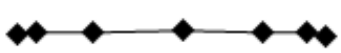

प曰口田早

平

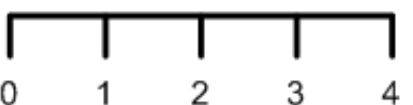

V2 Elapsed time (hrs)
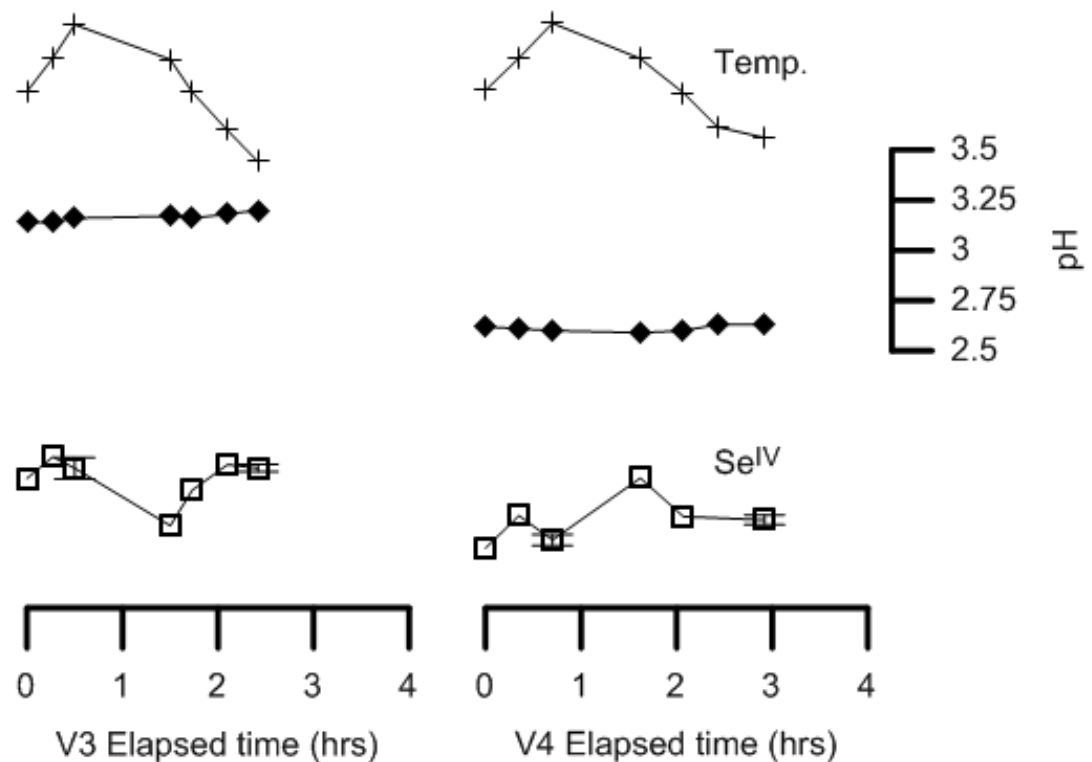

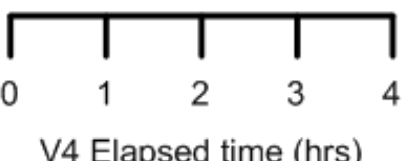

Figure 5-13. Cycle 5 (1/29/2015) results with all vessels (V1-V4) graphed separately. All vessels contained Se-only solutions. Standard deviations are represented by error bars for triplicate samples. 
concentration changes could be detected with increasing or decreasing temperature over a short time period. The light remained on for this experiment with an average light intensity of 1346 Lux. Se photo-redox cycles were not probable during these experiments; therefore, the light intensity was lower compared to previous experiments, because the light was located at a greater distance from the reaction vessels for better ease of sampling.

The $\mathrm{pH}$ was adjusted to 3.00 for all vessels at the beginning of the 48 hour equilibration period; however, at the beginning of the experiment, the $\mathrm{pH}$ values differed in each vessel. The $\mathrm{pH}$ in Vessel 3, averaging 3.16 standard $\mathrm{pH}$ units, was higher than the other three vessels which averaged 2.70 (Vessel 1), 2.63 (Vessel 2), and 2.61 (Vessel 4) (Figures 5-12 and 5-13, Table 5-9). $\mathrm{Se}^{\mathrm{IV}}$ concentrations did not cycle with temperature in this experiment. $\mathrm{Se}^{\mathrm{IV}}$ concentrations also displayed different trends in each vessel (Figures 5-12 and 5-13). Se ${ }^{\mathrm{IV}}$ cycles were likely not detected due to the short temperature cycle $(<3.5$ hours $)$.

\subsection{Cycle 6: 2/28/2015}

Two experiments, a 7-hour Fe-only temperature cycle and a 7-hour Fe-Se combined temperature cycle, were conducted on February 28, 2015 (Table 5-1). These experiments were conducted to determine if $\mathrm{Fe}$ and Se concentration changes could be detected with increasing and decreasing temperature. The light was turned off for these experiments to eliminate the possibility of $\mathrm{Fe}^{\mathrm{III}}$ photoreduction.

$\mathrm{Fe}^{\mathrm{II}}$ concentrations remained below the method detection limit in both the Fe-only and Fe-Se combined experiment vessels indicating that $\mathrm{Fe}^{\mathrm{III}}$ photoreduction likely did not occur in light off conditions. Fe(total) concentrations did not display any cycling trends with temperature (Figures 5-14 and 5-15, Table 5-10). $\mathrm{Se}^{\mathrm{IV}}$ cycled with temperature in one of the two Fe-Se combined experiment vessels (Vessel 3) (Figures 5-14 and 5-15).

Hysteresis was observed for $\mathrm{Se}^{\mathrm{IV}}$ concentrations in Vessel 3 (Figure 5-16). The log of $\mathrm{Se}^{\mathrm{IV}}$ concentrations (molar) was plotted versus 1/temperature (in Kelvin) to solve for enthalpy of sorption values in kJ/mol (Eq. 5, Figure 5-17, Table 5-11). 
Table 5-9. Cycle 5 (1/29/2015) parameter variability

\begin{tabular}{lcccccc}
\hline Parameter & Units & $\begin{array}{c}\text { Vessel } \\
\text { No. }\end{array}$ & Min. & Max. & $\begin{array}{c}\text { Range } \\
\text { (Min. - Max.) }\end{array}$ & Average \\
\hline Temperature & ${ }^{\circ} \mathrm{C}$ & 1 & 14.9 & 35.1 & 20.2 & 25.6 \\
& & 2 & 13.7 & 35.0 & 21.3 & 25.5 \\
& & 3 & 14.5 & 35.0 & 20.5 & 25.5 \\
& & 4 & 18.1 & 35.2 & 17.1 & 26.1 \\
\hline $\mathrm{pH}$ & --- & 2 & 2.68 & 2.72 & 0.04 & 2.70 \\
& & 2.61 & 2.64 & 0.03 & 2.63 \\
& & 3 & 3.14 & 3.20 & 0.06 & 3.16 \\
& & 4 & 2.59 & 2.63 & 0.04 & 2.61 \\
\hline $\mathrm{Se}^{\mathrm{IV}}$ & & 1 & 284.1 & 328.2 & 44.1 & 309.7 \\
& & 2 & 290.3 & 371.5 & 81.2 & 338.5 \\
& & 3 & 222.4 & 308.1 & 85.7 & 280.7 \\
& & 4 & 194.5 & 281.7 & 87.2 & 229.9 \\
\hline
\end{tabular}

Note: Min. is the minimum parameter value, and Max. is the maximum parameter value. 


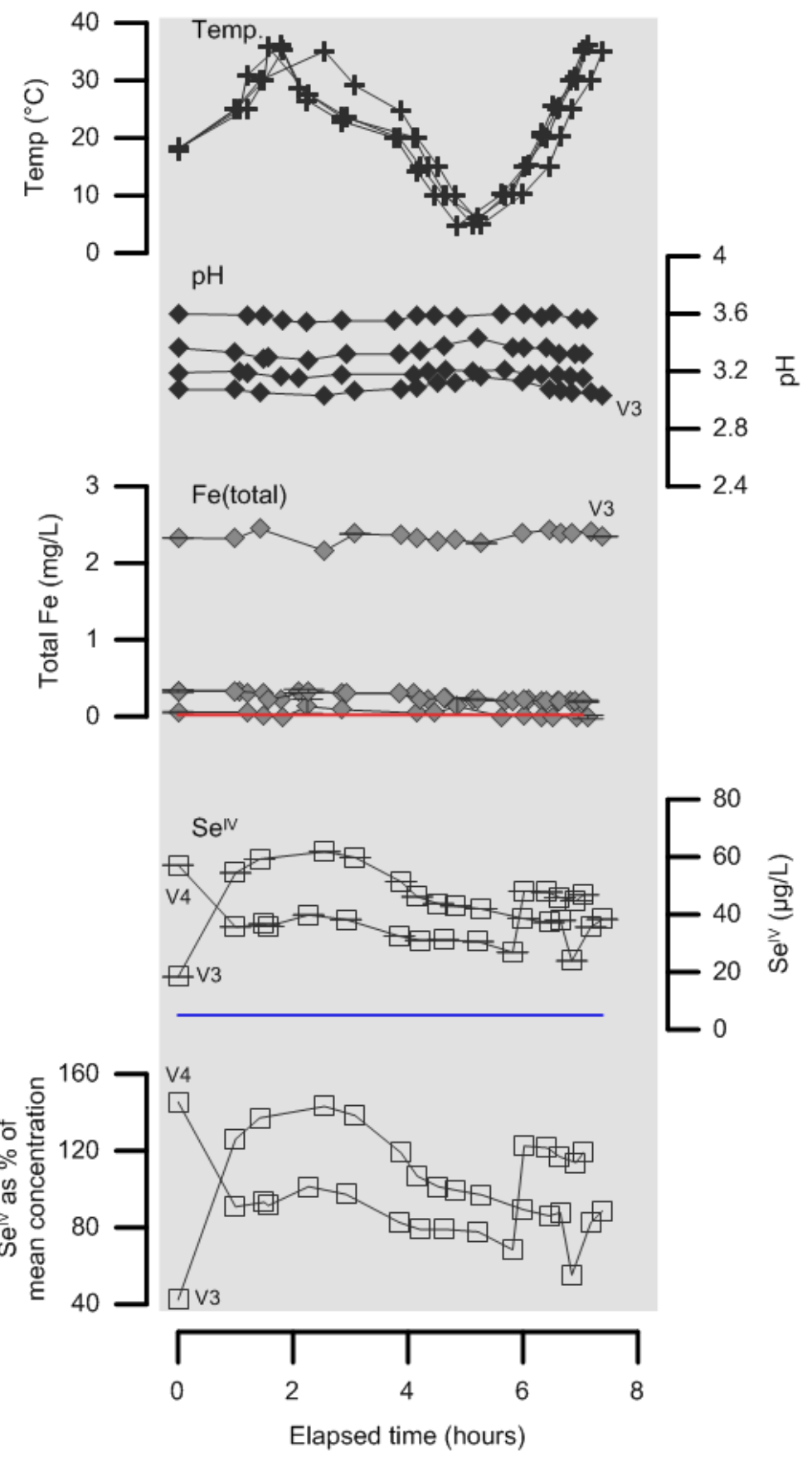

Figure 5-14. Cycle 6 (2/28/2015) results with all vessels (V1-V4) graphed together. Vessels 1 and 2 contained Fe-only solutions, whereas Vessels 3 and 4 contained Fe-Se solutions. The solid red line indicates the MDL for $\mathrm{Fe}^{\mathrm{II}}$ analysis $\left(0.02 \mathrm{mg} / \mathrm{L} \mathrm{Fe}^{\mathrm{II}}\right)$ on the HACH DR2800 Spectrophotometer. The solid blue line indicates the MDL for $\mathrm{Se}^{\mathrm{IV}}$ analysis $\left(5 \mu \mathrm{g} / \mathrm{L} \mathrm{Se}^{\mathrm{IV}}\right)$ on the Perkin Elmer Optima 2100 DV ICP-OES. Standard deviations are represented by error bars for triplicate samples. The gray shaded area indicates that the light was turned off for this experiment (dark conditions). 


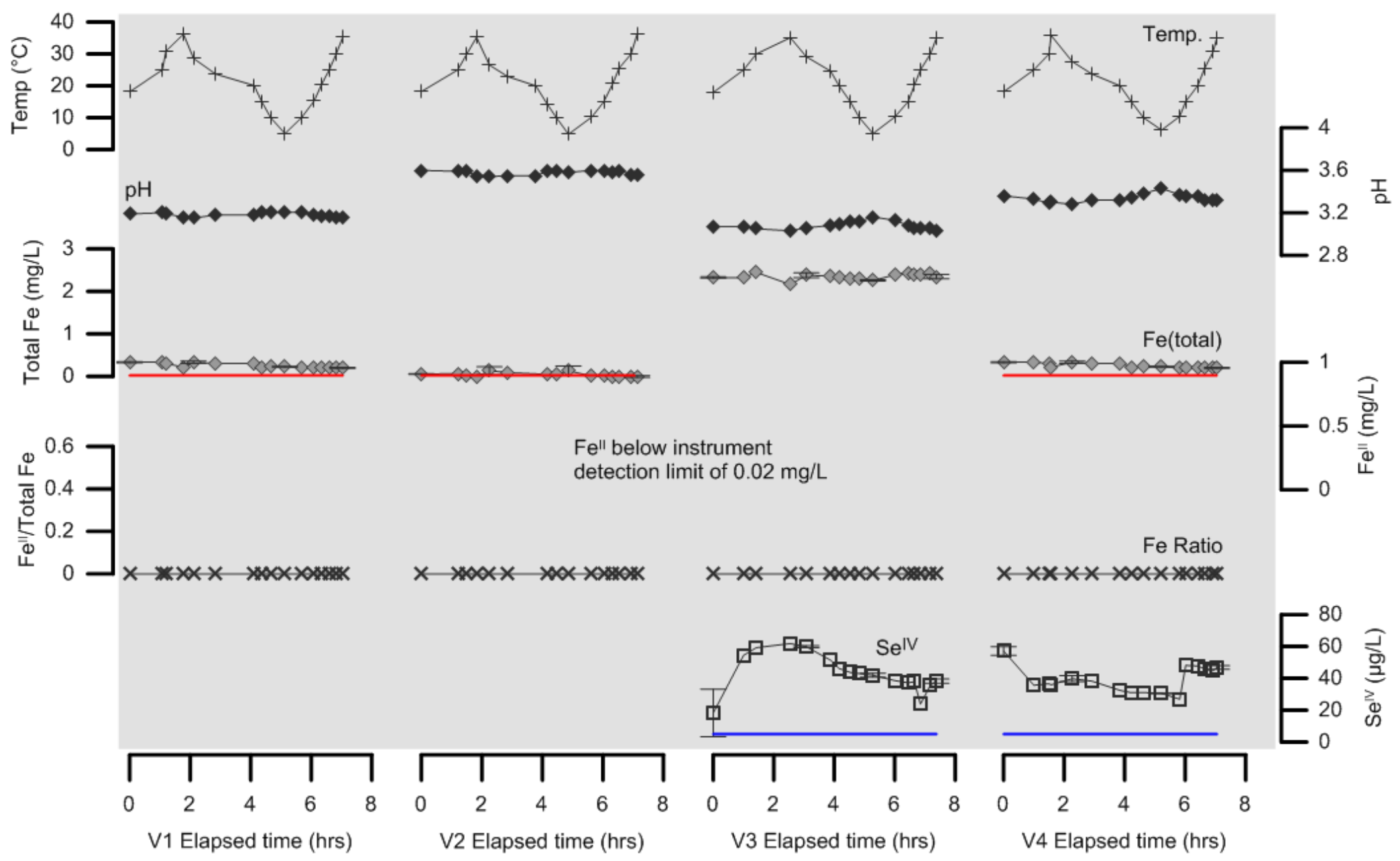

Figure 5-15. Cycle 6 (2/28/2015) results with all vessels (V1-V4) graphed separately. Vessels 1 and 2 contained Fe-only solutions, whereas Vessels 3 and 4 contained Fe-Se solutions. The solid red lines indicate the MDL for Fe ${ }^{\mathrm{II}}$ analysis $(0.02 \mathrm{mg} / \mathrm{L}$ $\left.\mathrm{Fe}^{\mathrm{II}}\right)$ on the HACH DR2800 Spectrophotometer. The solid blue lines indicate the MDL for Se $\mathrm{IV}^{\mathrm{IV}}$ analysis $\left(5 \mu \mathrm{g} / \mathrm{L} \mathrm{Se} \mathrm{IV}^{\mathrm{IV}}\right)$ on the Perkin Elmer Optima 2100 DV ICP-OES. Standard deviations are represented by error bars for triplicate samples. The gray shaded area indicates that the light was turned off for this experiment (dark conditions). 
Table 5-10. Cycle 6 (2/28/2015) parameter variability

\begin{tabular}{lcccccc}
\hline Parameter & Units & $\begin{array}{c}\text { Vessel } \\
\text { No. }\end{array}$ & Min. & Max. & $\begin{array}{c}\text { Range } \\
\text { (Min. - Max.) }\end{array}$ & Average \\
\hline Temperature & ${ }^{\circ} \mathrm{C}$ & 1 & 5.0 & 36.2 & 31.2 & 21.8 \\
& & 2 & 4.8 & 36.2 & 31.4 & 21.6 \\
& & 3 & 5.0 & 35.1 & 30.1 & 21.7 \\
& & 4 & 6.1 & 35.8 & 29.7 & 21.8 \\
\hline $\mathrm{pH}$ & --- & 1 & 3.19 & 3.25 & 0.06 & 3.22 \\
& & 2 & 3.54 & 3.60 & 0.06 & 3.58 \\
& & 3 & 3.03 & 3.16 & 0.13 & 3.08 \\
& & 4 & 3.28 & 3.43 & 0.15 & 3.34 \\
\hline $\mathrm{Fe}$ (total) & $\mathrm{mg} / \mathrm{L}$ & 1 & 0.198 & 0.332 & 0.133 & 0.252 \\
& & 2 & $<0.02$ & 0.132 & 0.143 & 0.036 \\
& & 3 & 2.161 & 2.447 & 0.286 & 2.346 \\
& & 4 & 0.198 & 0.332 & 0.133 & 0.252 \\
\hline $\mathrm{Se}{ }^{\mathrm{IV}}$ & $\mu \mathrm{gg} / \mathrm{L}$ & 3 & 18.3 & 61.8 & 43.6 & 43.2 \\
& & 4 & 26.9 & 57.2 & 30.3 & 39.3 \\
\hline
\end{tabular}

Note: Min. is the minimum parameter value, and Max. is the maximum parameter value. All Fe ${ }^{\mathrm{II}}$ concentrations were below the MDL of $0.02 \mathrm{mg} / \mathrm{L}$. 


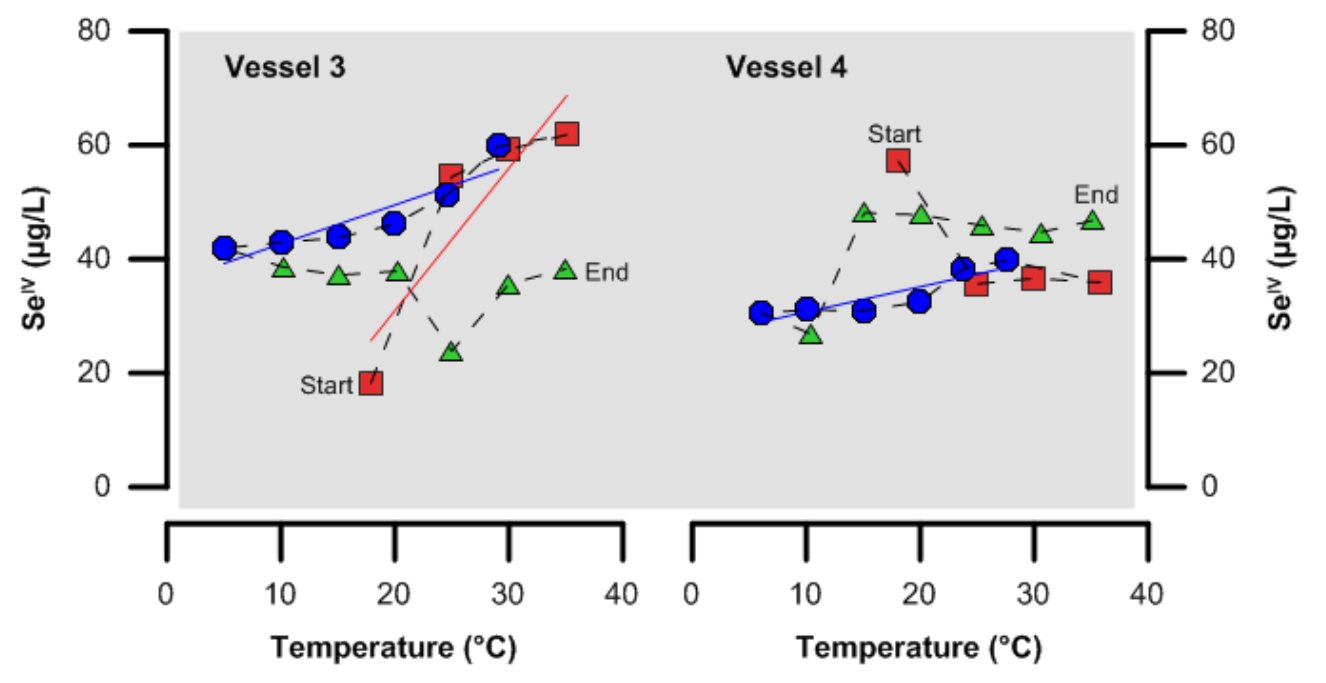

Figure 5-16. Cycle 6 (2/28/2015) relationship between $\mathrm{Se}^{\mathrm{IV}}$ concentrations and temperature. The start and end of each cycle is labeled next to the corresponding data symbol (red square). Red squares represent the first temperature increasing series, blue circles represent the temperature decreasing series, and green triangles represent the second temperature increasing series. Solid red lines are linear regression lines for the first temperature increasing series. Solid blue lines are linear regression lines for the temperature decreasing series. The black dashed lines indicate the order in which samples were collected over time. The gray shaded area indicates that the light was turned off for this experiment (dark conditions). 


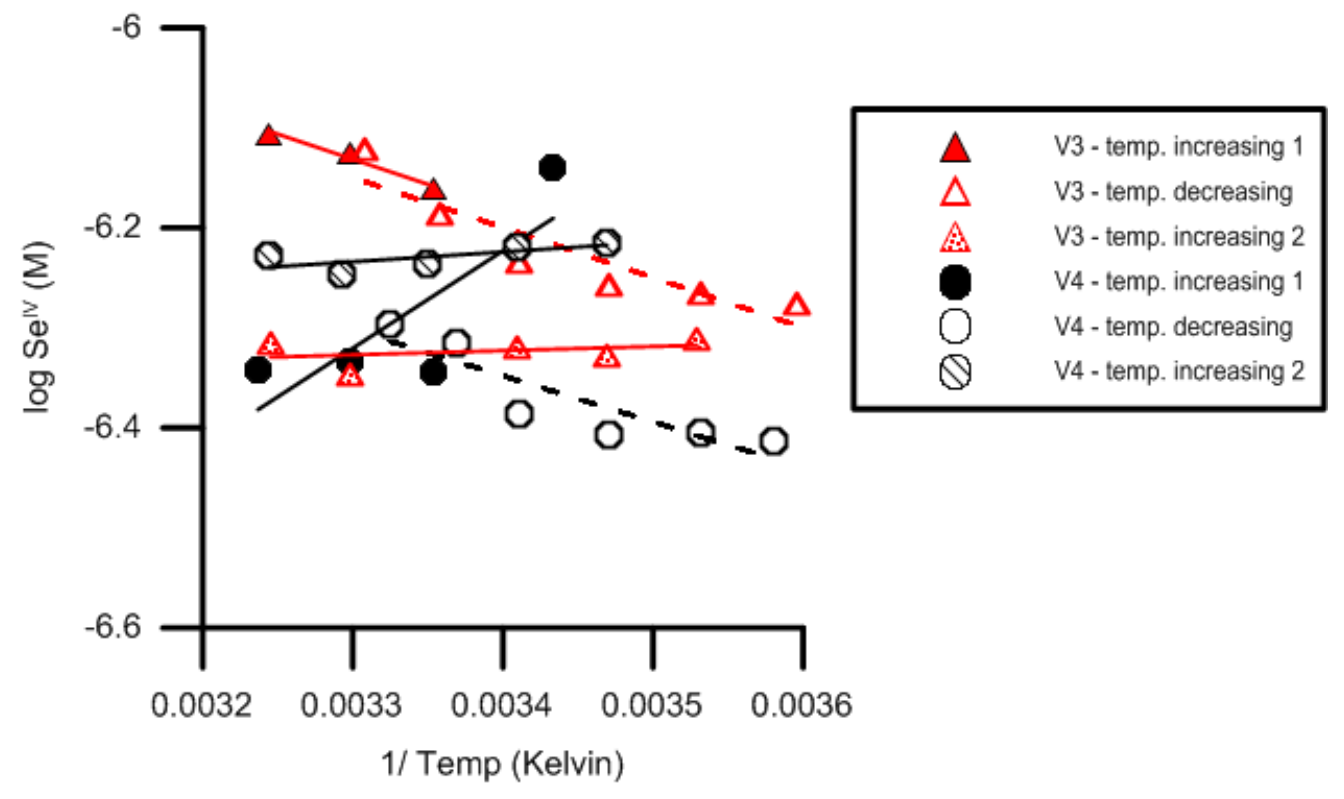

Figure 5-17. Enthalpy of sorption plot for Cycle 6 (2/28/2015). The increasing temperature series 1 (solid symbols and solid lines), decreasing temperature series (open symbols and dashed lines), and increasing temperature series 2 (patterned symbols and solid lines) data are plotted separately for each vessel. Vessel numbers are labelled V3 and V4. 
Table 5-11. Conditional Enthalpies of Sorption for Cycle 6

\begin{tabular}{lccccc}
\hline $\begin{array}{l}\text { Temperature } \\
\text { (increase/decrease) }\end{array}$ & $\begin{array}{c}\text { Vessel } \\
\text { No. }\end{array}$ & $\mathbf{R}^{\mathbf{2}}$ & slope & $\mathbf{n}$ & $\begin{array}{c}\text { Enthalpy } \\
\text { (kJ/ mol) }\end{array}$ \\
\hline Increase 1 & 3 & 0.967 & -502.5 & 3 & -9.62 \\
Increase 1 & 4 & 0.660 & 973.0 & 4 & 18.6 \\
\hline Decrease & 3 & 0.833 & -500.4 & 6 & -9.58 \\
Decrease & 4 & 0.789 & -460.4 & 6 & -8.82 \\
\hline Increase 2 & 3 & 0.126 & 41.68 & 5 & 0.798 \\
Increase 2 & 4 & 0.466 & 98.35 & 5 & 1.88 \\
\hline
\end{tabular}

Note: $\mathrm{R}^{2}$ is the coefficient of determination. $\mathrm{n}$ is the number of data points. Outlying data points were removed from the temperature increase 1 series and from the temperature increase 2 series calculations for Vessel 3. An outlying data point was also removed from the temperature increase 2 series calculation for Vessel 4. 


\subsection{Cycle 7: 4/26/2015}

A 7-hour Se-only temperature cycle was completed on April 26, 2015 (Table 5-1). The purpose of this experiment was to determine if Se concentration changes could be detected over a longer time period than Cycle 5. The light was turned on for this experiment, and the average light intensity was 110 Lux. Se photo-redox cycles were not probable during these experiments; therefore, the light intensity was lower compared to previous experiments, because the light was located at a greater distance from the reaction vessels for better ease of sampling.

$$
\mathrm{Se}^{\mathrm{IV}} \text { cycled with temperature in all four vessels (Figures 5-18 and 5-19, Table 5-12). }
$$
Hysteresis was observed for all $\mathrm{Se}^{\mathrm{IV}}$ concentrations versus temperature (Figure 5-20). The $\log$ of $\mathrm{Se}^{\mathrm{IV}}$ concentrations (molar) was plotted versus 1/temperature (in Kelvin) to solve for enthalpy of sorption values in $\mathrm{kJ} / \mathrm{mol}$ (Eq. 5, Figure 5-21, Table 5-13). This experiment revealed that Se concentrations can cycle with temperature, even without the presence of 2-line ferrihydrite or Fe species in solution. 

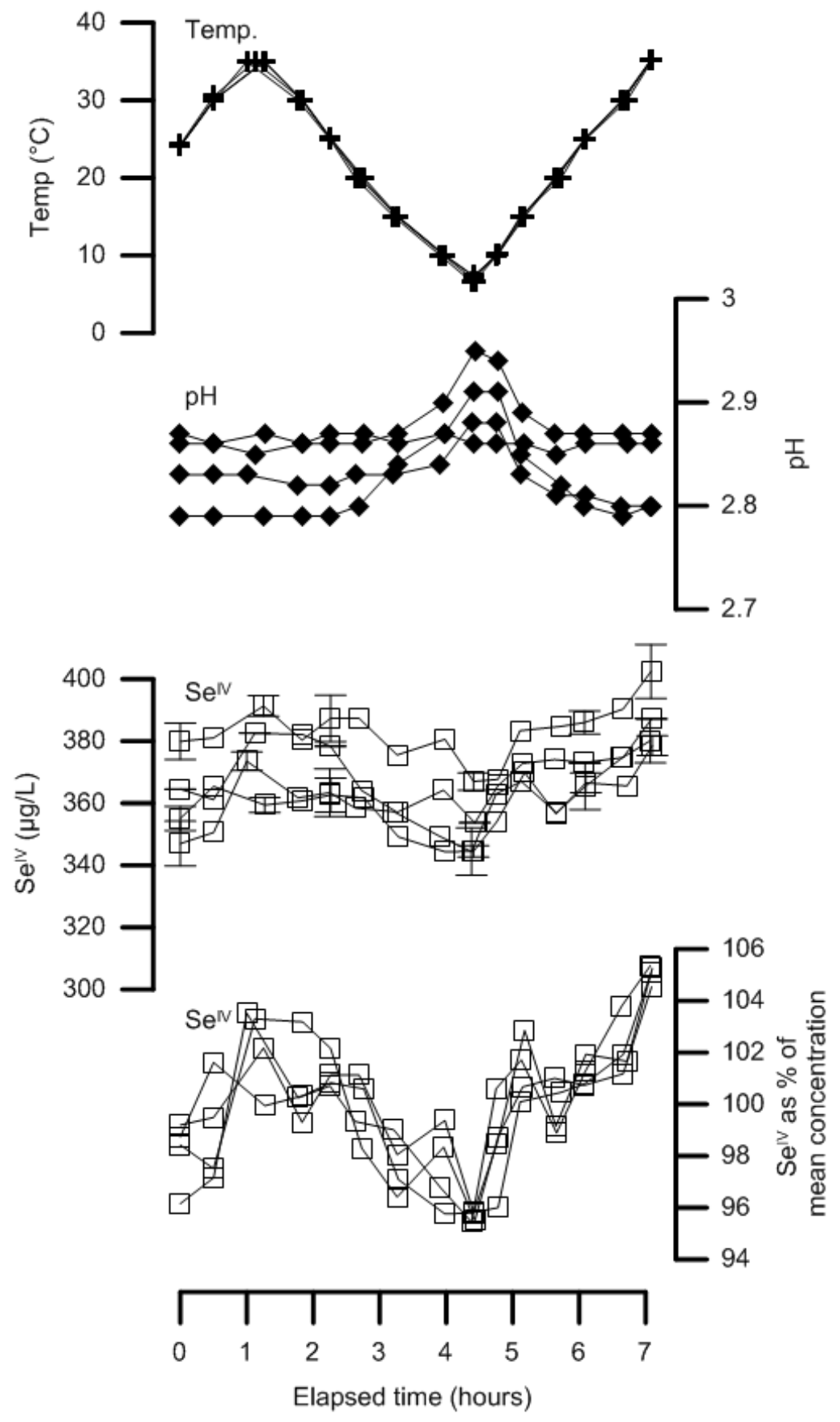

Figure 5-18. Cycle 7 (4/26/2015) results with all vessels (V1-V4) graphed together. All vessels contained Se-only solutions. Standard deviations are represented by error bars for triplicate samples. 

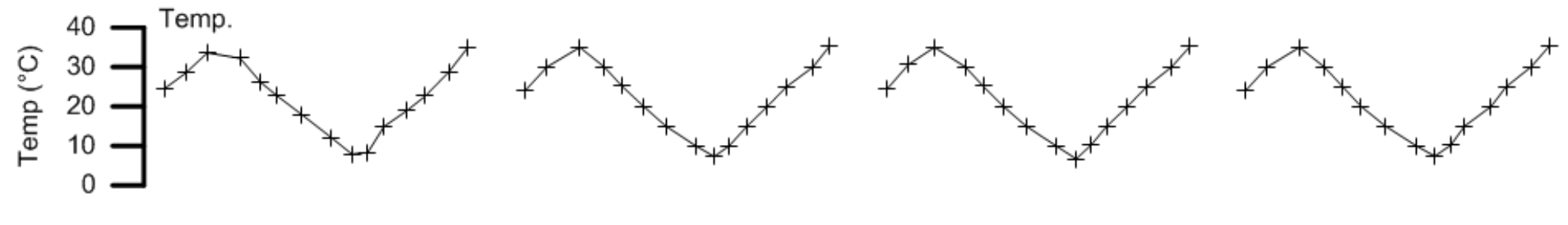

$\mathrm{pH}$
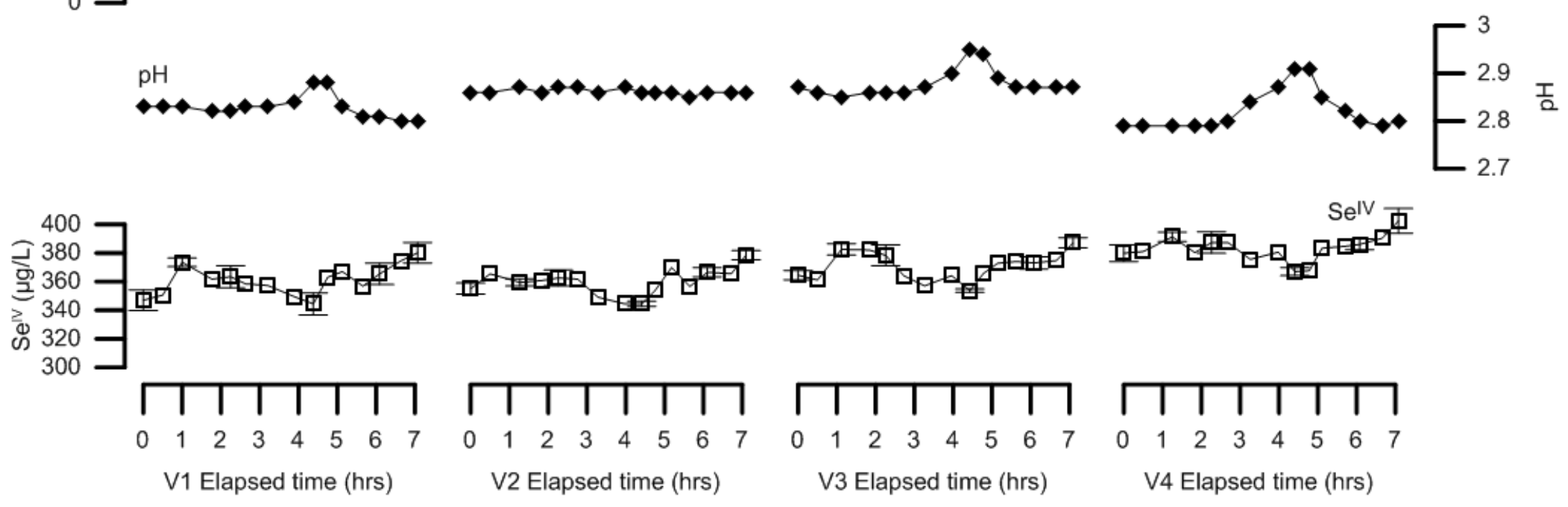

Figure 5-19. Cycle 7 (4/26/2015) results with all vessels (V1-V4) graphed separately. All vessels contained Se-only solutions. Standard deviations are represented by error bars for triplicate samples. 
Table 5-12. Cycle 7 (4/26/2015) parameter variability

\begin{tabular}{lcccccc}
\hline Parameter & Units & $\begin{array}{c}\text { Vessel } \\
\text { No. }\end{array}$ & Min. & Max. & $\begin{array}{c}\text { Range } \\
\text { (Min. - Max.) }\end{array}$ & Average \\
\hline Temperature & ${ }^{\circ} \mathrm{C}$ & 1 & 6.6 & 35.1 & 28.5 & 22.1 \\
& & 2 & 7.3 & 35.2 & 27.9 & 22.1 \\
& & 3 & 6.7 & 35.2 & 28.5 & 22.1 \\
& & 4 & 7.4 & 35.2 & 27.8 & 22.1 \\
\hline $\mathrm{pH}$ & --- & 1 & 2.80 & 2.88 & 0.08 & 2.83 \\
& & 2 & 2.85 & 2.87 & 0.02 & 2.86 \\
& & 3 & 2.85 & 2.95 & 0.10 & 2.88 \\
& & 4 & 2.79 & 2.91 & 0.12 & 2.82 \\
\hline $\mathrm{Se}^{\mathrm{IV}}$ & & 1 & 344.4 & 380.2 & 35.8 & 360.8 \\
& & 2 & 344.4 & 378.5 & 34.2 & 359.6 \\
& & 3 & 353.7 & 387.2 & 33.5 & 370.4 \\
& & 4 & 367.0 & 402.5 & 35.5 & 383.0 \\
\hline
\end{tabular}

Note: Min. is the minimum parameter value, and Max. is the maximum parameter value. 

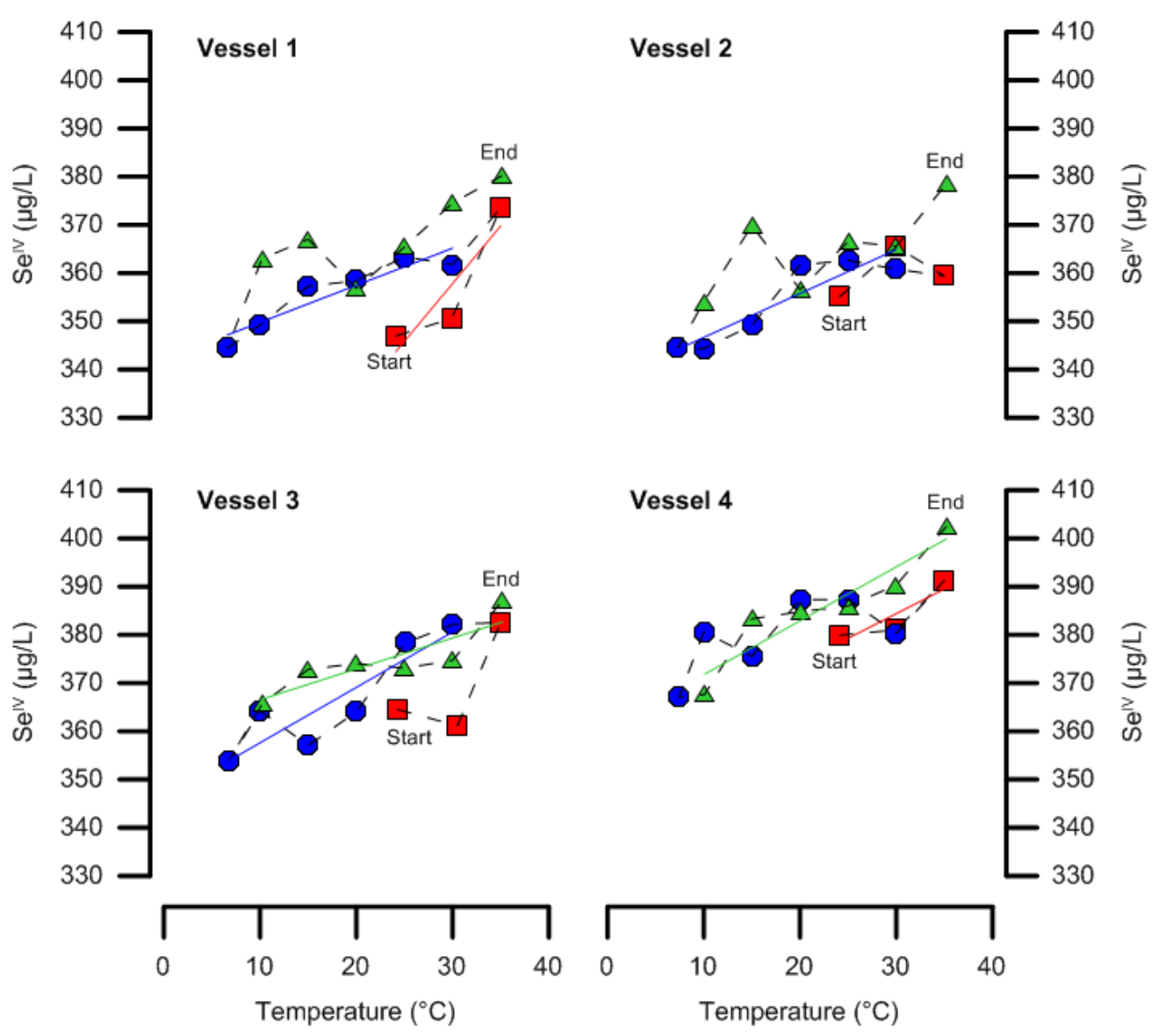

Figure 5-20. Cycle 7 (4/26/2015) relationship between $\mathrm{Se}^{\mathrm{IV}}$ concentrations and temperature. The start and end of each cycle is labeled next to the corresponding data symbol (red square). Red squares represent the first temperature increasing series, blue circles represent the temperature decreasing series, and green triangles represent the second temperature increasing series. Solid red lines are linear regression lines for the first temperature increasing series. Solid blue lines are linear regression lines for the temperature decreasing series. Solid green lines are linear regression lines for the second temperature increasing series. The black dashed lines indicate the order in which samples were collected over time. 


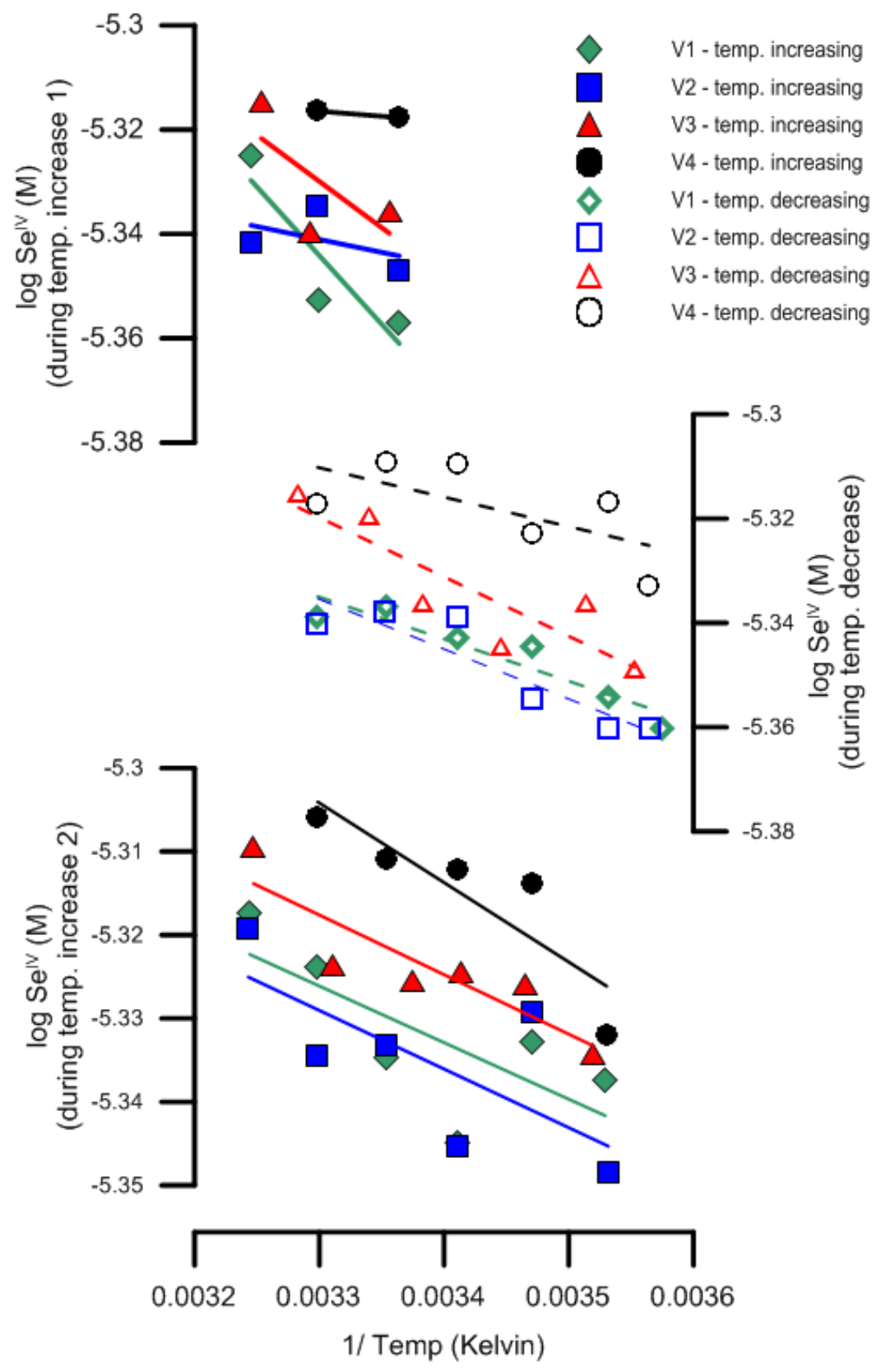

Figure 5-21. Enthalpy of sorption plot for Cycle 7 (4/26/2015). Increasing temperature (solid symbols and lines) and decreasing temperature (open symbols and dashed lines) data are plotted separately for each vessel. Vessel numbers are labelled V1 through V4. 
Table 5-13. Conditional Enthalpies of Sorption for Cycle 7

\begin{tabular}{lccccc}
\hline $\begin{array}{l}\text { Temperature } \\
\text { (increase/decrease) }\end{array}$ & $\begin{array}{c}\text { Vessel } \\
\text { No. }\end{array}$ & $\mathbf{R}^{\mathbf{2}}$ & slope & $\mathbf{n}$ & $\begin{array}{c}\text { Enthalpy } \\
\text { (kJ/ mol) }\end{array}$ \\
\hline Increase 1 & 1 & 0.817 & -263.3 & 3 & -5.0 \\
Increase 1 & 2 & 0.223 & -49.57 & 3 & -0.9 \\
Increase 1 & 3 & 0.468 & -177.4 & 3 & -3.4 \\
Increase 1 & 4 & 1 & -19.41 & 2 & -0.4 \\
\hline Decrease & 1 & 0.873 & -80.60 & 6 & -1.5 \\
Decrease & 2 & 0.838 & -95.61 & 6 & -1.8 \\
Decrease & 3 & 0.766 & -113.8 & 6 & -2.2 \\
Decrease & 4 & 0.429 & -56.33 & 6 & -1.1 \\
\hline Increase 2 & 1 & 0.543 & -67.79 & 6 & -1.3 \\
Increase 2 & 2 & 0.507 & -70.23 & 6 & -1.3 \\
Increase 2 & 3 & 0.786 & -71.35 & 6 & -1.4 \\
Increase 2 & 4 & 0.773 & -1825 & 5 & -1.8 \\
\hline
\end{tabular}

Note: $\mathrm{R}^{2}$ is the coefficient of determination. $\mathrm{n}$ is the number of data points. An outlying data point was removed from the temperature increase 1 series calculation for Vessel 4. 


\section{DISCUSSION}

\subsection{Comparison of similar cycles}

Since solution components and experiment conditions differed for each cycle, the cycles were separated into groups (Fe-only, Se-only, and Fe-Se combined experiments) (Table 6-1) for comparison. The purpose of this section is to identify similarities and differences within each group of cycles.

\subsubsection{Fe-only cycles}

The Fe-only experiments included cycles 1, 2, 4 and 6 (Table 6-1). For Cycles 1 and 2, the light was turned on and off in an attempt to drive Fe cycles with light via $\mathrm{Fe}^{\mathrm{III}}$ photoreduction; however, it was found that the effects of temperature and light could not be separated due to the heating of solution when the light was turned on.

For Cycle 1, Fe ${ }^{\mathrm{II}}$ concentrations were below the MDL. This was likely due to the short equilibration time and the short period of time the light was turned on. The $\mathrm{Fe}^{\mathrm{II}}$ concentrations for Cycle 2 were above the MDL indicating that $\mathrm{Fe}^{\mathrm{III}}$ photoreduction occurred during this light cycle experiment. In comparison to Cycle 1, Cycle 2 had a longer equilibration time which resulted in an increased Fe(total) concentration. Therefore, the likelihood of $\mathrm{Fe}^{\mathrm{III}}$ photoreduction and $\mathrm{Fe}^{\mathrm{II}}$ detection was higher, due to the larger $\mathrm{Fe}^{\mathrm{III}}$ species concentration in solution when the light was turned on.

The temperature was manually controlled for Cycles 4 and 6. The light remained on for Cycle 4 and was turned off during Cycle 6 (Table 6-1). Fe ${ }^{\mathrm{II}}$ concentrations were detected in Cycle 4, but were below the MDL in Cycle 6, indicating that $\mathrm{Fe}^{\mathrm{III}}$ photoreduction was occurring only when the light was turned on. The Fe(total) concentration for Cycle 6 in Vessel 3 was much higher than the other vessels. This was due to the lower $\mathrm{pH}$ value of the Vessel 3 solution, ranging from 3.03 to 3.16. The $\mathrm{pH}$ values in Cycle 4 ranged from 2.66 to 3.35, and the Fe(total) concentrations were greater than those in Cycle 6. In both experiments, Fe(total) concentrations 
Table 6-1. Summary of cycles by group (Fe-only, Se-only, and Fe-Se combined)

\begin{tabular}{|c|c|c|c|c|c|c|c|}
\hline $\begin{array}{c}\text { Cycle } \\
\text { No. }\end{array}$ & Date & $\begin{array}{c}\text { No. } \\
\text { Vessels }\end{array}$ & $\begin{array}{c}\text { 2-line } \\
\text { ferrihydrite } \\
\text { (mg) }\end{array}$ & $\begin{array}{c}\mathrm{Se}^{\mathrm{IV}} \\
(\mu \mathrm{g} / \mathrm{L})\end{array}$ & Light & $\begin{array}{c}\text { Approx. } \\
\text { temperature } \\
\text { range }\end{array}$ & $\begin{array}{c}\begin{array}{c}\text { Experiment } \\
\text { time } \\
\text { (hours) }\end{array} \\
\end{array}$ \\
\hline \multicolumn{8}{|c|}{ Fe-only cycles } \\
\hline 1 & $7 / 22-23 / 14$ & 1 & 500 & --- & Cycle & $21-23{ }^{\circ} \mathrm{C}$ & 22 \\
\hline 2 & $10 / 17-18 / 14$ & 4 & 500 & --- & Cycle & $23-26^{\circ} \mathrm{C}$ & 30 \\
\hline 4 & $12 / 9 / 14$ & 2 & 500 & --- & On & $0-35^{\circ} \mathrm{C}$ & 10 \\
\hline 6 & $2 / 28 / 15$ & 2 & 500 & --- & Off & $0-35{ }^{\circ} \mathrm{C}$ & 7 \\
\hline \multicolumn{8}{|c|}{ Se-only cycles } \\
\hline 5 & $1 / 29 / 15$ & 4 & --- & 300 & On & $10-35^{\circ} \mathrm{C}$ & 3.5 \\
\hline 7 & $4 / 26 / 15$ & 4 & --- & 300 & On & $5-35^{\circ} \mathrm{C}$ & 7 \\
\hline \multicolumn{8}{|c|}{ Fe-Se cycles } \\
\hline 3 & $10 / 25 / 15$ & 4 & 500 & 3000 & Off & $10-35{ }^{\circ} \mathrm{C}$ & 10 \\
\hline 4 & $12 / 9 / 14$ & 2 & 500 & 300 & On & $0-35^{\circ} \mathrm{C}$ & 10 \\
\hline 6 & $2 / 28 / 15$ & 2 & 500 & 300 & Off & $0-35^{\circ} \mathrm{C}$ & 7 \\
\hline
\end{tabular}


did not cycle with temperature. However, in Cycle 4, $\mathrm{Fe}^{\mathrm{II}}$ concentrations appeared to cycle with a slight lag behind the change in temperature (Figure 5-9).

\subsubsection{Se-only cycles}

The Se-only experiments included cycles 5 and 7 (Table 6-1). The light was turned on for both experiments, because Fe was not present in solution. Se oxidation state and Se sorption to glassware are also not known to change in light off versus light on conditions. Cycle 5 was a partial temperature cycle (temperature increase then temperature decrease), whereas Cycle 7 was a full temperature cycle (temperature increase, temperature decrease, then a second temperature increase). $\mathrm{Se}^{\mathrm{IV}}$ concentrations did not cycle in phase with temperature in Cycle 5. This was likely due to the short run time of the experiment (3.5 hours). Cycle 7 did display $\mathrm{Se}^{\mathrm{IV}}$ concentration cycles with temperature. For all vessels, the initial $\mathrm{Se}^{\mathrm{IV}}$ concentration was $300 \mu \mathrm{g} / \mathrm{L}$; however, due to solution preparation and potential evaporation loss, a -20 to $+50 \mu \mathrm{g} / \mathrm{L}$ uncertainty was estimated. Although the initial and reported $\mathrm{Se}^{\mathrm{IV}}$ concentrations throughout the experiment may be biased high, the overall trends in concentration with temperature are consistent for each vessel. The cycling of $\mathrm{Se}^{\mathrm{IV}}$ with changes in temperature suggests that $\mathrm{Se}^{\mathrm{IV}}$ was likely sorbing to the glass reaction vessels during the experiments. The magnitude of these concentration changes are small in comparison to Fe-Se combined cycles (Table 6-2), likely due to the additional sorption surfaces provided by the solid 2-line ferrihydrite in Fe-Se experiments.

\subsubsection{Fe-Se combined cycles}

The Fe-Se experiments included cycles 3, 4, and 6 (Table 6-1). Cycle 3 and Cycle 6 were completed in the dark, whereas Cycle 4 was completed in the light. The solutions for Cycles 4 and 6 consisted of $300 \mu \mathrm{g} / \mathrm{L} \mathrm{Se}^{\mathrm{IV}}$, whereas the Cycle 3 solution consisted of $3000 \mu \mathrm{g} / \mathrm{L} \mathrm{Se}^{\mathrm{IV}} \cdot \mathrm{Se}^{\mathrm{IV}}$ concentration cycles were observed in both light and dark conditions. Cycle 6 and Cycle 4 each had one vessel in which $\mathrm{Se}^{\mathrm{IV}}$ concentrations did not cycle with temperature. These two vessels had the highest $\mathrm{pH}$ values of all Fe-Se experiments (Figures 5-9 and 5-15). 
Table 6-2. Comparison of Se-only and Fe-Se cycles

\begin{tabular}{|c|c|c|c|c|c|c|c|c|c|c|}
\hline $\begin{array}{c}\text { Cycle } \\
\text { No. }\end{array}$ & Vessel & $\begin{array}{c}\text { Light } \\
\text { (on/off) }\end{array}$ & $\begin{array}{l}\text { Se cycle } \\
\text { (yes/no) }\end{array}$ & $\begin{array}{c}\text { Initial } \\
\mathrm{Se}^{\mathrm{IV}} \\
(\mu \mathrm{g} / \mathrm{L})\end{array}$ & $\begin{array}{c}\mathrm{Sean}^{\mathrm{IV}} \\
(\mu \mathrm{gg} / \mathrm{L})\end{array}$ & $\begin{array}{c}\% \\
\mathrm{Se}^{\mathrm{IV}} \\
\operatorname{lost}^{\mathrm{a}}\end{array}$ & $\begin{array}{c}\text { Max. } \\
\text { pH }\end{array}$ & $\underset{\text { pH }}{\operatorname{Min} .}$ & $\begin{array}{c}\text { Mean } \\
\text { pH }\end{array}$ & $\begin{array}{l}\mathrm{Se}^{\mathrm{IV}} \% \\
\text { Range }^{\mathrm{b}}\end{array}$ \\
\hline \multicolumn{11}{|c|}{ Se-only cycles } \\
\hline 5 & V1 & on & no & 300 & 310 & $\mathrm{x}$ & 2.72 & 2.68 & 2.70 & 15 \\
\hline 5 & V2 & on & no & 300 & 339 & $\mathrm{x}$ & 2.64 & 2.61 & 2.63 & 27 \\
\hline 5 & V3 & on & no & 300 & 281 & 6.3 & 3.20 & 3.14 & 3.16 & 29 \\
\hline 5 & V4 & on & no & 300 & 230 & 23 & 2.63 & 2.59 & 2.61 & 38 \\
\hline 7 & V1 & on & yes & 300 & 361 & $\mathrm{x}$ & 2.88 & 2.80 & 2.83 & 9.9 \\
\hline 7 & V2 & on & yes & 300 & 360 & $\mathrm{x}$ & 2.87 & 2.85 & 2.86 & 9.6 \\
\hline 7 & V3 & on & yes & 300 & 370 & $\mathrm{x}$ & 2.95 & 2.85 & 2.88 & 9.9 \\
\hline 7 & V4 & on & yes & 300 & 383 & $\mathrm{x}$ & 2.91 & 2.79 & 2.82 & 9.5 \\
\hline \multicolumn{11}{|c|}{ Fe-Se cycles } \\
\hline 3 & V1 & off & yes & 3000 & 233 & 92 & 2.99 & 2.96 & 2.97 & 73 \\
\hline 3 & V2 & off & yes & 3000 & 306 & 90 & 3.00 & 2.96 & 2.98 & 48 \\
\hline 3 & V3 & off & yes & 3000 & 293 & 90 & 3.18 & 3.16 & 3.17 & 39 \\
\hline 3 & V4 & off & yes & 3000 & 233 & 92 & 2.97 & 2.92 & 2.94 & 50 \\
\hline 4 & V3 & on & no & 300 & 12.1 & 96 & 3.35 & 2.98 & 3.20 & 43 \\
\hline 4 & V4 & on & yes & 300 & 48.0 & 84 & 2.98 & 2.66 & 2.74 & 103 \\
\hline 6 & V3 & off & yes & 300 & 43.2 & 86 & 3.16 & 3.03 & 3.08 & 88 \\
\hline 6 & V4 & off & no & 300 & 39.4 & 87 & 3.43 & 3.30 & 3.34 & 77 \\
\hline
\end{tabular}

${ }^{\mathrm{a}}$ The difference between the initial and mean concentrations, divided by the initial concentration; ${ }^{\mathrm{b}}$ The difference in the maximum and minimum values for the percent of mean concentration. This parameter is provided to compare the magnitudes of $\mathrm{Se}^{\mathrm{IV}}$ cycles; $\mathrm{x}$ is effectively zero within the error of the measurement. 
The magnitude of $\mathrm{Se}^{\mathrm{IV}}$ concentration cycles was much larger for $\mathrm{Fe}-\mathrm{Se}$ experiments than Se-only experiments. This was likely due to the greater affinity for $\mathrm{Se}^{\mathrm{IV}}$ species sorption to solid 2-line ferrihydrite rather than the glass reaction vessels. For each individual Fe-Se and Se-only cycle, the "Se ${ }^{\mathrm{IV}} \%$ Range" was calculated by taking the difference between the maximum and minimum $\mathrm{Se}^{\mathrm{IV}}$ values, divided by the mean $\mathrm{Se}^{\mathrm{IV}}$ concentration, and reported as a percentage. This value was used to determine the difference in $\mathrm{Se}^{\mathrm{IV}}$ concentration cycle magnitudes between experiments. For Se-only experiments, the $\mathrm{Se}^{\mathrm{IV}} \%$ range was less than $10 \%$ (Cycle 7 only; no $\mathrm{Se}^{\mathrm{IV}}$ cycles reported for Cycle 5). The $\mathrm{Se}^{\mathrm{IV}} \%$ range values ranged from $39 \%$ to $88 \%$ in $\mathrm{Fe}-\mathrm{Se}$ combined experiments indicating that the magnitude of $\mathrm{Se}^{\mathrm{IV}}$ concentration changes were greater for these experiments.

For Cycles 3, 4, 6 and 7, the observed $\mathrm{Se}^{\mathrm{IV}}$ cycles displayed increasing $\mathrm{Se}^{\mathrm{IV}}$ concentrations with increasing temperature and decreasing $\mathrm{Se}^{\mathrm{IV}}$ concentrations with decreasing temperature. Graphs of $\mathrm{Se}^{\mathrm{IV}}$ concentration versus temperature resulted in a hysteresis relationship between sorption (decreasing $\mathrm{Se}^{\mathrm{IV}}$ concentrations) and desorption (increasing $\mathrm{Se}^{\mathrm{IV}}$ concentrations) processes. Conditional enthalpy of sorption values were calculated for Cycles 3 , 4,6 , and 7 and ranged from -61.9 to $19.4 \mathrm{~kJ} / \mathrm{mol}$ for the first increasing temperature series, from -23.6 to $2.6 \mathrm{~kJ} / \mathrm{mol}$ for the temperature decreasing series, and from -17.2 to $11.7 \mathrm{~kJ} / \mathrm{mol}$ for the second temperature increasing series. Anions, such as the aqueous $\mathrm{Se}^{\mathrm{IV}}$ species present in the experiment solutions, are known to cycle out of phase with cations (Nimick et al., 2003). Nimick et al. (2003) calculated negative conditional enthalpies of sorption for As, which like Se, forms anionic species in solution. Therefore, the negative conditional enthalpy of sorption values reported above for $\mathrm{Se}^{\mathrm{IV}}$ are consistent with the Nimick et al. (2003) findings for As. The large range of values reported for $\mathrm{Se}^{\mathrm{IV}}$ in these experiments are likely due to the differing vessel conditions. It is also important to note that not all $\mathrm{Se}^{\mathrm{IV}}$ loss may have been due to sorption onto 2-line ferrihydrite and that oxidation-reduction reactions are not considered in the conditional enthalpy of sorption calculation. 


\subsection{Evaluation of mechanisms}

\subsubsection{Light}

It was predicted that $\mathrm{Fe}^{\mathrm{III}}$ photoreduction would occur during light on conditions, resulting in increased $\mathrm{Fe}^{\mathrm{II}}$ concentrations. During light control experiments (turning the light on and off while holding temperature constant), this process was predicted to result in Fe redox cycling. However, Fe ${ }^{\mathrm{III}}$ photoreduction and Fe redox cycling did not occur during Fe-only light control experiments (Cycles 1 and 2). Therefore, $\mathrm{Se}^{\mathrm{IV}}$ concentration changes could not be evaluated relative to Fe redox or precipitation cycles in these experiments.

There are a few possible reasons why $\mathrm{Fe}^{\mathrm{III}}$ photoreduction was not observed. The light bulbs used in these experiments were within the optimum wavelength (360 to $450 \mathrm{~nm}$ ) for Fe ${ }^{\mathrm{III}}$ photoreduction, and the $\mathrm{pH}$ was also within the correct range (3 to 4) (Gammons et al., 2008; King et al., 1993; McKnight et al., 2001); however, the light intensity emitted from the bulbs may not have been strong enough for $\mathrm{Fe}^{\mathrm{III}}$ photoreduction to occur. Second, if Fe ${ }^{\mathrm{III}}$ photoreduction was occurring, the time period in which the light was turned on may not have been long enough to observe any changes in $\mathrm{Fe}^{\mathrm{II}}$ concentrations. Lastly, the dissolution of 2-line ferrihydrite was minimal, and the solid remained at the base of the reaction vessels during the experiments. The concentrations of $\mathrm{Fe}(\mathrm{OH})^{2+}$, the aqueous $\mathrm{Fe}$ species needed for $\mathrm{Fe}^{\mathrm{III}}$ photoreduction, may not have been high enough for Fe ${ }^{\mathrm{III}}$ photoreduction to occur (Kimball et al., 1992) (Eq. 6). Kimball et al. (1992) also described how Fe ${ }^{\mathrm{III}}$ can be released from Fe oxide minerals into solution by direct photoreduction at the mineral surface (Eq. 7a and 7b); however, in the light and temperature cycle experiments, the light intensity was likely not strong enough to reach the mineral surface at the bottom of the reaction vessels.

During temperature control experiments with the light off (Cycles 3 and 6), $\mathrm{Fe}^{\mathrm{II}}$ concentrations remained relatively low, ranging from below the MDL to $0.147 \mathrm{mg} / \mathrm{L}$. The Fe ${ }^{\mathrm{II}}$ concentrations during the temperature control experiment with the light on (Cycle 4) ranged from $0.246 \mathrm{mg} / \mathrm{L}$ to $0.381 \mathrm{mg} / \mathrm{L}$. These higher $\mathrm{Fe}^{\mathrm{II}}$ concentration values suggest that $\mathrm{Fe}^{\mathrm{III}}$ photoreduction did occur during light on conditions. However, the $\mathrm{Fe}^{\mathrm{II}}$ concentrations did not continue to increase throughout the light on temperature control experiment (Cycle 4), meaning that $\mathrm{Fe}^{\mathrm{III}}$ photoreduction may have reached its maximum during the 48 hour equilibration period 
prior to the experiment. Overall, the lights and Fe species concentration changes had no effect on $\mathrm{Se}^{\mathrm{IV}}$ concentrations.

\subsubsection{Temperature}

$\mathrm{Fe}$ (total) concentration variations did not directly correlate with changes in temperature, and the concentrations remained relatively stable throughout the light and temperature cycle experiments, ranging from $<0.02 \mathrm{mg} / \mathrm{L}$ to $2.45 \mathrm{mg} / \mathrm{L}(<0.01 \%$ to $1.56 \%$ of the total mass of Fe added to each vessel). Parker et al. (2007) found that the solubility of HFO decreases with increasing temperature. This is also observed in the ferrihydrite solubility diagram (Figure 2.6) which was created with the same parameters (ionic strength and Fe concentration) as the reaction vessel Fe-only solution. At a pH of 3 in Figure 2.6, the Fe(total) concentrations were $19.3 \mathrm{mg} / \mathrm{L}$ at $10^{\circ} \mathrm{C}, 3.42 \mathrm{mg} / \mathrm{L}$ at $25^{\circ} \mathrm{C}$, and $1.22 \mathrm{mg} / \mathrm{L}$ at $30^{\circ} \mathrm{C}$. The maximum Fe(total) concentration in the temperature cycle experiments was $2.45 \mathrm{mg} / \mathrm{L}$ which lies between the $25^{\circ} \mathrm{C}$ and $30^{\circ} \mathrm{C} \mathrm{Fe}$ (total) concentration values in Figure 2.6. Since Fe(total) concentrations did not decrease with increasing temperature during the temperature control experiments, it is likely that the temperature changes occurred too quickly to detect changes in Fe(total) concentrations associated with HFO dissolution and precipitation.

Fe redox cycling was also not observed with changes in temperature. In Cycle 4, the $\mathrm{Fe}^{\mathrm{II}}$ concentrations cycled with a slight lag behind temperature changes in all four vessels. $\mathrm{Fe}^{\mathrm{II}}$ concentration changes with temperature were not observed in any other cycles. $\mathrm{Fe}^{\mathrm{II}}$ concentration increases with temperature increases have been observed in natural waters (Parker et al., 2007; Gammons et al., 2005a); however, it was determined that $\mathrm{Fe}^{\mathrm{III}}$ photoreduction was a stronger influence on $\mathrm{Fe}^{\mathrm{II}}$ cycles in those studies. Gammons et al. (2005a) found that $\mathrm{Fe}^{\mathrm{II}}$ concentrations had larger magnitude diel cycles than $\mathrm{Fe}^{\mathrm{III}}$ concentrations. Temperature is known to create a kinetic effect for Fe cycles by increasing Fe oxidation rates in warmer water (Wakao and Shiota, 1982). Therefore, the increase in temperature during daytime hours in the Gammons et al. (2005a) study should have favored $\mathrm{Fe}^{\mathrm{II}}$ oxidation. The larger magnitude of $\mathrm{Fe}^{\mathrm{II}}$ diel cycles in comparison with $\mathrm{Fe}^{\mathrm{III}}$ diel cycles indicates that $\mathrm{Fe}^{\mathrm{III}}$ photoreduction was the dominant process in their study. 
Temperature was the main driver of all observed $\mathrm{Se}^{\mathrm{IV}}$ cycles. $\mathrm{Se}^{\mathrm{IV}}$ concentrations were positively correlated with temperature in both Se-only and Fe-Se combined vessels. This resulted in negative $\Delta \mathrm{H}_{\text {ads }}$ values, indicating that $\mathrm{Se}^{\mathrm{IV}}$ sorption was increasing with decreasing temperature and vice versa. These results are consistent with the Nimick et al. (2003) findings for As concentration changes with temperature. The time period in which temperature changes occur is also important. If the temperature changes too quickly, then $\mathrm{Se}^{\mathrm{IV}}$ concentration changes may not be detected (e.g. Cycle 5).

\subsubsection{Se sorption onto 2-line ferrihydrite}

The changes in $\mathrm{Se}^{\mathrm{IV}}$ concentrations during Se-only and $\mathrm{Fe}-\mathrm{Se}$ experiments were likely due to temperature-dependent sorption onto 2-line ferrihydrite. In comparison to Se-only cycles, larger magnitude $\mathrm{Se}^{\mathrm{IV}}$ cycles were observed in Fe-Se combined cycles. This was attributed to the presence of 2-line ferrihydrite in the Fe-Se vessels providing additional sorption sites for $\mathrm{Se}^{\mathrm{IV}}$.

For all Se-only and $\mathrm{Fe}-\mathrm{Se}$ experiments, $\mathrm{Se}^{\mathrm{IV}}$ was always present in solution, meaning that not all $\mathrm{Se}^{\mathrm{IV}}$ sorbed to the glassware and 2-line ferrihydrite.

Majority of the calculated $\Delta \mathrm{H}_{\text {ads }}$ values were negative, which is consistent with anion sorption (Nimick et al., 2003) (Tables 5-6, 5-8, 5-11, and 5-13). Machesky's (1990) chemical modeling approach for $\Delta \mathrm{H}_{\mathrm{ads}}$ of Se $\mathrm{IV}^{\mathrm{IV}}$ onto ferrihydrite resulted in exothermic $\Delta \mathrm{H}_{\text {ads }}$ values of -82 $\mathrm{kJ} / \mathrm{mol}$ to $-22 \mathrm{~kJ} / \mathrm{mol}$. For Fe-Se temperature control experiments, 5 out of $20 \Delta \mathrm{H}_{\text {ads }}$ values fell within this range. $\Delta \mathrm{H}_{\text {ads }}$ values for $\mathrm{Se}^{\mathrm{IV}}$ onto $\mathrm{HFO}$ have not been reported in natural waters. For Fe-Se temperature cycle experiments, $\Delta \mathrm{H}_{\text {ads }}$ values for $\mathrm{Se}^{\mathrm{IV}}$ onto 2-line ferrihydrite ranged from $-61.9 \mathrm{~kJ} / \mathrm{mol}$ to $19.4 \mathrm{~kJ} / \mathrm{mol}$ (20 values total) for both temperature increasing and temperature decreasing series. Out of those $20 \Delta \mathrm{H}_{\text {ads }}$ values, 13 were negative. For the Se-only temperature cycle experiments, $\Delta \mathrm{H}_{\mathrm{ads}}$ values for $\mathrm{Se}^{\mathrm{IV}}$ onto the glassware ranged from $-5.0 \mathrm{~kJ} / \mathrm{mol}$ to -0.4 $\mathrm{kJ} / \mathrm{mol}$, and all 12 values were negative.

The reported studies of Se diel cycles in nature (Carling et al., 2011; Dicataldo et al., 2011) concluded that Se cycled due to sorption interactions with metal oxides caused by changes in $\mathrm{pH}$ and redox conditions. The changes in $\mathrm{pH}$ were attributed to photosynthesis, and a direct correlation between $\mathrm{Se}^{\mathrm{IV}}$ concentration changes and temperature was not observed. It is important to note that the $\mathrm{pH}$ range in these studies (7.5 to 9.7 ) was significantly different from 
the $\mathrm{pH}$ range used in the laboratory experiments, therefore, resulting in different Se species concentrations and sorption behavior. Also, photosynthesis did not occur in the laboratory experiments. Laboratory sorption studies have shown that $\mathrm{Se}^{\mathrm{IV}}$ sorption onto ferrihydrite increases with decreasing temperature and $\mathrm{pH}$ (Balistrieri and Chao, 1990; Parida et al., 1997). $\mathrm{Se}^{\mathrm{IV}}$ concentrations during the Se-only and Fe-Se temperature cycle experiments followed this same trend. As the vessel solution temperatures decreased, $\mathrm{Se}^{\mathrm{IV}}$ concentrations also decreased $\left(\mathrm{Se}^{\mathrm{IV}}\right.$ sorbed onto the glassware and 2-line ferrihydrite).

There are several other factors that may affect $\mathrm{Se}^{\mathrm{IV}}$ sorption onto ferrihydrite, including ionic strength, surface loading, timing, $\mathrm{pH}$, and the Se species present (Sparks, 2003). KCl was used to fix the ionic strength of solution; however, the ionic strength of solution was found to increase throughout the temperature cycle experiments due to evaporation. $\mathrm{KCl}$ was chosen, because $\mathrm{K}^{+}$and $\mathrm{Cl}^{-}$both act as conservative ions and did not interfere with Fe or Se species in solution. It is also unlikely that full surface loading of Se species was occurring in these experiments, because the mass of 2-line ferrihydrite added to the vessels was much greater than the mass of $\mathrm{Se}^{\mathrm{IV}}$ added. Timing is also important. For example, $\mathrm{Se}^{\mathrm{IV}}$ cycles were not observed in Cycle 5, which was likely due to the temperature cycling too quickly. The $\mathrm{pH}$ of vessel solutions did not cycle in the temperature cycle experiments, but different $\mathrm{pH}$ values were observed in each vessel. Slight changes in $\mathrm{pH}$ may affect Se species concentrations in solution, and each Se species may have a different affinity for sorption onto 2-line ferrihydrite.

\subsection{4 pH}

For all experiments, the solution $\mathrm{pH}$ was adjusted to 3 prior to the 48 hour equilibration period. After the equilibration period, $\mathrm{pH}$ values ranged from 2.59 to 3.60 during the light and temperature cycle experiments. The change in $\mathrm{pH}$ values after equilibration could be due to 2line ferrihydrite dissolution and/or Fe species conversions. The solution $\mathrm{pH}$ values did not cycle with temperature or light and remained relatively constant in each vessel.

At low $\mathrm{pH}$ values, $\mathrm{Se}^{\mathrm{IV}}$ and $\mathrm{Se}^{\mathrm{VI}}$ species will protonate to form acids (Eq. 1, 2, and 3). Each Se species may have a different affinity for sorption onto 2-line ferrihydrite. Also, $\mathrm{Se}^{\mathrm{IV}}$ sorption is more likely to occur with decreasing $\mathrm{pH}$ (Parida et al., 1997). Se $\mathrm{IV}^{\mathrm{IV}}$ cycles were not observed in vessel solutions with a $\mathrm{pH}$ value greater than 3 . Therefore, the $\mathrm{pH}$ of the vessel 
solutions was critical for $\mathrm{Se}^{\mathrm{IV}}$ sorption and cycling. As $\mathrm{pH}$ increases, the protonation of HFO surfaces decreases, which results in an increased negative surface charge (Nimick et al., 2003). This may explain why clear $\mathrm{Se}^{\mathrm{IV}}$ cycles were not observed in vessel solutions with $\mathrm{pH}$ values greater than 3. Parida et al. (1997) found that $\mathrm{Se}^{\mathrm{IV}}$ will adsorb onto ferrihydrite at $\mathrm{pH}$ values greater than the $\mathrm{pH}_{\mathrm{PZC}}$ (ferrihydrite $\mathrm{pH}_{\mathrm{PZC}}=7.89 \pm 0.1$ ). This occurs when $\mathrm{Se}^{\mathrm{IV}}$ and ferrihydrite interactions are able to exceed electrostatic forces. Since $\mathrm{pH}$ values in the light and temperature cycle experiments were less than the $\mathrm{pH}_{\mathrm{PZC}}$ for ferrihydrite, this process did not have an effect on $\mathrm{Se}^{\mathrm{IV}}$ cycles; however, other types of specific interactions (non-electrostatic) may have occurred between the $\mathrm{Se}^{\mathrm{IV}}$ species and 2-line ferrihydrite surface.

The importance of $\mathrm{pH}$ in As diel cycles was described by Nimick et al. (1998). Like Se, As forms oxyanions in water and should display similar behavior in response to $\mathrm{pH}$ changes. Nimick et al. (1998) found that As diel cycles were only present in the Madison and Missouri Rivers within certain $\mathrm{pH}$ ranges. If the $\mathrm{pH}$ was too high, As concentrations did not cycle. Although Nimick et al.'s (1998) study was completed in natural waters with higher $\mathrm{pH}$ values (ranging from 7.2 to 9.0) than the light and temperature cycle experiments of this study, it highlights the significance of $\mathrm{pH}$ on oxyanion cycling.

The $\mathrm{pH}$ of solution is also important for 2-line ferrihydrite dissolution and precipitation. Specific Fe species may only be present in certain $\mathrm{pH}$ ranges (Figure 2-6). Other HFOs may also precipitate or dissolve at specific $\mathrm{pH}$ values, therefore, impacting Fe species and $\mathrm{Se}^{\mathrm{IV}}$ concentrations in solution. Gammons et al. (2005a) reported that Fe(total) concentrations decreased with increasing $\mathrm{pH}$ values downstream at their study site (Fishing Creek, Montana). The decrease in $\mathrm{Fe}$ (total) concentrations was due to HFO precipitation with increasing $\mathrm{pH}$. Nimick et al. (2003) concluded that the dissolution of HFO is associated with acidic waters and could be linked with increases in $\mathrm{Fe}^{\mathrm{II}}$ and $\mathrm{Fe}$ (total) concentrations.

\subsubsection{Oxidation-reduction reactions}

It is unlikely that $\mathrm{Se}^{\mathrm{IV}}$ oxidation occurred during the Se-only and $\mathrm{Fe}-\mathrm{Se}$ experiments. However, it is possible that $\mathrm{Se}^{\mathrm{IV}}$ oxidation can be coupled with $\mathrm{Fe}^{\mathrm{III}}$ reduction (Eq.12 and Eq. $13)$. 


$$
\begin{aligned}
& \mathrm{H}_{2} \mathrm{Se}^{\mathrm{IV}} \mathrm{O}_{3}+\mathrm{H}_{2} \mathrm{O}+2 \mathrm{Fe}^{\mathrm{III}} \leftrightarrow \mathrm{Se}^{\mathrm{IV}} \mathrm{O}_{4}^{-2}+4 \mathrm{H}^{+}+2 \mathrm{Fe}^{\mathrm{II}} \\
& \mathrm{HSe}^{\mathrm{IV}} \mathrm{O}_{3}^{-}+\mathrm{H}_{2} \mathrm{O}+2 \mathrm{Fe}^{\mathrm{III}} \leftrightarrow \mathrm{Se}^{\mathrm{IV}} \mathrm{O}_{4}^{-2}+3 \mathrm{H}^{+}+2 \mathrm{Fe}^{\mathrm{II}}
\end{aligned}
$$

These reactions are dependent on the solution $\mathrm{pH}$, because it affects the protonation and deprotonation of Fe and Se species. Equation 12 may occur at $\mathrm{pH}$ values between 1.66 and 2.62, and Equation 13 may occur between pH values of 2.62 and 8.32 (Figure 6-1). The Gibbs Free Energy of Reaction $\left(\Delta \mathrm{G}_{\mathrm{R}}\right)$ can also be used to determine whether Equations 12 and 13 were likely to occur during temperature controlled experiments. The $\Delta \mathrm{G}_{\mathrm{R}}$ for Equation 12 is greater than zero, indicating that the thermodynamics are not favorable for the reaction to occur. However, the $\Delta \mathrm{G}_{\mathrm{R}}$ for Equation 13 is negative at $\mathrm{pH}$ values above 3.5, indicating that $\mathrm{Se}^{\mathrm{IV}}$ oxidation to $\mathrm{Se}^{\mathrm{VI}}$ may occur when $\mathrm{Fe}^{\mathrm{III}}$ exists in solution at $\mathrm{pH}$ values greater than 3.5 . Since all vessel solution $\mathrm{pH}$ values were less than 3.5 , the oxidation of $\mathrm{Se}^{\mathrm{IV}}$ to $\mathrm{Se}^{\mathrm{VI}}$ likely did not occur during these experiments. Based on solution $\mathrm{pH}$, all $\mathrm{Se}^{\mathrm{IV}}$ cycles were observed due to sorption onto 2-line ferrihydrite. Therefore, the final mass balance equation for Se in the reaction vessels is written as:

$$
[\mathrm{Se}]_{\text {Total }}=\left[\mathrm{Se}^{\mathrm{IV}}\right]_{\text {aqueous }}+\left[\mathrm{Se}^{\mathrm{IV}}\right]_{\text {sorbed to Fe }}
$$



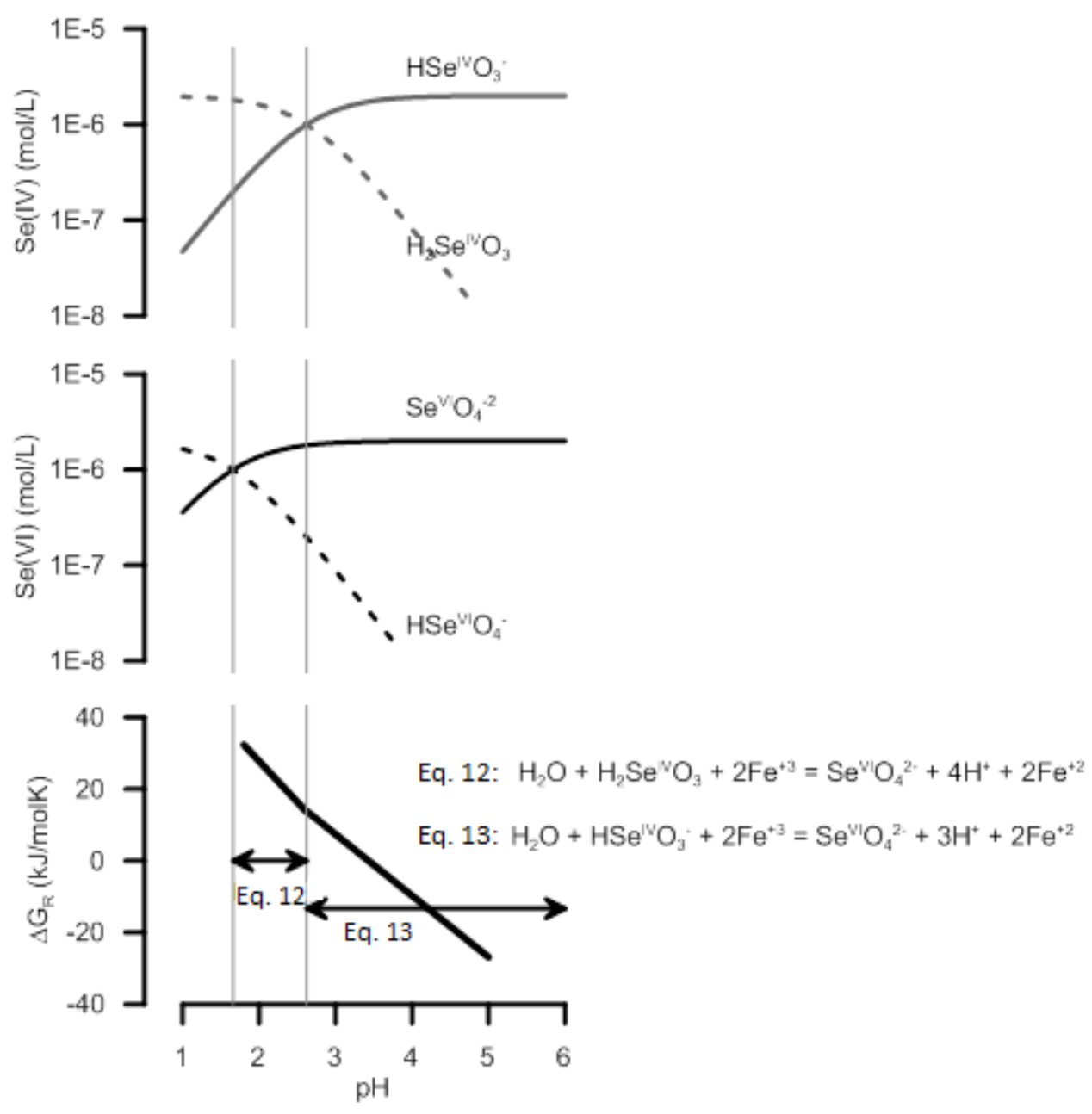

Figure 6-1. Gibbs Free Energy $\left(\Delta \mathrm{G}_{\mathrm{R}}\right)$ calculated using thermodynamic data from Stumm and Morgan (1996) for $\left[\mathrm{Se}^{\mathrm{IV}}\right]=\left[\mathrm{Se}^{\mathrm{VI}}\right]=3.8 \times 10^{-6} \mathrm{M}$ and $\left[\mathrm{Fe}^{\mathrm{III}}\right]=\left[\mathrm{Fe}^{\mathrm{II}}\right]=9 \times 10^{-6} \mathrm{M}$. Activity-concentration corrections not included. Modified from the final OSMRE report (Vesper et al., 2015). 


\section{CONCLUSIONS}

This research demonstrates that Se concentration cycles can be controlled by temperature change in acidic solutions $\left(\mathrm{pH}<3\right.$ ). The hypothesis that $\mathrm{Se}^{\mathrm{IV}}$ (including the protonated and deprotonated species) will cycle in phase with $\mathrm{Fe}$ due to $\mathrm{Se}^{\mathrm{IV}}$ species sorption onto 2-line ferrihydrite (i.e. as Fe moves from the solid to the dissolved phase it will release the existing sorbed $\mathrm{Se}^{\mathrm{IV}}$ species) could not be verified from this research due to the existence of $\mathrm{Se}^{\mathrm{IV}}$ cycles in Se-only experiments and the lack of Fe cycles. Although clear Fe cycles were not observed, the magnitude of $\mathrm{Se}^{\mathrm{IV}}$ cycles was more pronounced in Fe-Se vessels than in Se-only vessels indicating that $\mathrm{Se}^{\mathrm{IV}}$ was being sorbed onto and released from the 2-line ferrihydrite. The results of these experiments provide insight to the possible causes and limitations of $\mathrm{Se}^{\mathrm{IV}}$ diel cycles in natural waters. The time period over which temperature changed, the solution $\mathrm{pH}$, and the presence of an adsorbent (2-line ferrihydrite) were all important for defining the magnitude of $\mathrm{Se}^{\mathrm{IV}}$ cycles observed. 


\section{FUTURE WORK}

Further study is needed to determine if Se cycles can be linked to Fe redox cycles. If Fe redox cycles are created, then $\mathrm{Se}^{\mathrm{IV}}$ concentration changes could be observed. It would be necessary to obtain a light source that emits a greater light intensity than the standard UV bulbs used in these experiments to generate $\mathrm{Fe}^{\mathrm{III}}$ photoreduction. This would increase the chances of $\mathrm{Fe}^{\mathrm{III}}$ photoreduction for light control experiments. The effects of temperature and light must also be separated by manually controlling temperature (keeping it constant) during light control experiments. Other $\mathrm{Fe}^{\mathrm{III}}$ minerals with equivalent or greater solubility than 2-line ferrihydrite could be used to introduce Fe into solution. Similar studies can also be completed to determine the effect of trace metal redox cycles on $\mathrm{Se}^{\mathrm{IV}}$ concentrations with light and temperature (e.g. Are $\mathrm{Se}^{\mathrm{IV}}$ cycles linked to manganese (Mn) redox cycles?). 


\section{REFERENCES}

Allison, J.D., Brown, D.S. and Novo-Gradac, K., 1991. MINTEQA2/PRODEFA2, A Geochemical Assessment Model for Environmental Systems.

Balistrieri, L.S. and Chao, T.T., 1987. Selenium Adsorption by Geothite. Soil Science Society of America Journal, 51(5): 1145-1151.

Benjamin, M.M., 2002. Water Chemistry. Waveland Press, Inc., Long Grove, Illinois, 368 pp.

Carling, G.T., Fernandez, D.P., Rudd, A., Pazmino, E. and Johnson, W.P., 2011. Trace Element Diel Variations and Particulate Pulses in Perimeter Freshwater Wetlands of the Great Salt Lake, Utah. Chemical Geology, 283: 87-98.

Coleman, L., Bragg, L.J. and Finkelman, R.B., 1993. Distribution and Mode of Occurrence of Selenium in US Coals. Environmental Geochemistry and Health, 15: 215-227.

Das, S., Hendry, M.J. and Essilfie-Dughan, J., 2013. Adsorption of Selenate onto Ferrihydrite, Goethite, and Lepidocrocite Under Neutral pH Conditions. Applied Geochemistry, 28: 185-193.

Dicataldo G., Johnson W.P., Naftz, D.L., Hayes, D.F., Moellmer, W.O. and Miller, T., 2011. Diel Variation of Selenium and Arsenic in a Wetland of the Great Salt Lake, Utah. Applied Geochemistry, 26: 28-36.

Duc, M., Lefèvre, G. and Fédoroff, M., 2006. Sorption of Selenite Ions on Hematite. Journal of Colloid and Interface Science, 298(2): 556-563.

Drever, J.I., 1997. The Geochemistry of Natural Waters: Surface and Groundwater Environments. Prentice Hall, Upper Saddle River, New Jersey, 142 pp.

Emmenegger, L., Schonenberger, R., Sigg, L. and Sulzberger, B., 2011. Light-induced Redox Cycling of Iron in Lakes. Limnol. Oceanogr., 46(1): 49-61.

Fuller, C.C. and Davis, J.A., 1989. Influence of Coupling of Sorption and Photosynthetic Processes on Trace Element Cycles in Natural Waters. Nature, 340: 52-54.

Gammons, C. H., Nimick D. A., Parker S.R., Cleasby T. E. and McCleskey R. B., 2005a. Diel Behavior of Iron and Other Heavy Metals in a Mountain Stream with Acidic to Neutral pH: Fisher Creek, Montana, USA. Geocimicha Et Cosmochimica Acta, 69(10): 2505-2516.

Gammons, C.H., Nimick, D.A., Parker, S.R., Snyder, D.M., McCleskey, R.B., Amils, R. and Poulson, S.R., 2008. Photoreduction Fuels Biogeochemical Cycling of Iron in Spain's Acid Rivers. Chemical Geology, 252: 202 -213.

Gammons, C.H., Wood, S.A. and Nimick, D.A., 2005b. Diel Behavior of Rare Earth Elements in a Mountain Stream with Acidic to Neutral pH. Geocimicha Et Cosmochimica Acta, 69: 3747-3758.

Huang, D. \& West Virginia University, 2010. Heterogeneous Reduction of Selenite by Zero Valent Iron-steel Wool. Morgantown, W. Va: West Virginia University Libraries.

Kimball, B.A., McKnight, D.M., Wetherbee, G.A. and Harnish, R.A., 1992. Mechanisms of Iron Photoreduction in a Metal-rich, Acidic Stream (St. Kevin Gulch, Colorado, U.S.A.).

The Geochemistry of Acid Groundwater Systems, 1(2): 227-239.

King, D.W., Aldrich, R.A. and Charnecki, S.E., 1993. Photochemical Redox Cycling of Iron in $\mathrm{NaCl}$ Solutions. Marine Chemistry, 44(2-4): 105-120.

Konieczka, P., Namiesnik, J., 2009. Quality Assurance and Quality Control in the Analytical Chemical Laboratory. CRC Press, Boca Raton, FL, 146-147 pp. 
Lee, W.C., Kim, S., Ranville, J., Yun, S. and Choi, S.H., 2014. Sequestration of Arsenate from Aqueous Solution Using 2-line Ferrihydrite: Equilibria, Kinetics, and X-ray Absorption Spectroscopic Analysis. Environmental Earth Science, 71: 3307-3318.

Lenz, M. and Lens, P.N.L., 2009. The Essential Toxin: the Changing Perception of Selenium in Environmental Sciences. Science of the Total Environment, 407: 3620-3633.

Lide, D.R. (Editor), 2003. CRC Handbook of Chemistry and Physics, $84^{\text {th }}$ Edition. CRC Press, Boca Raton, Florida, Appendix F.

Machesky M., 1990. Influence of Temperature on Ion Adsorption by Hydrous Metal Oxides. Chemical Modeling of Aqueous Systems II, 416: 282-292.

Manceau A. and Charlet, L., 1994. The Mechanism of Selenate Adsorption on Geothite and Hydrous Ferric Oxide. Journal of Colloid and Interface Science, 168(1): 87-93.

Marathon Scientific, 2007. Multimode Sample Introduction System (MSIS) User's Guide US Patent \# 6,891,605. Marathon Scientific, Canada, 3-4 pp.

McKnight, D.M., Kimball, B.A. and Bencala, K.E., 1988. Iron Photoreduction and Oxidation in an Acidic Mountain Stream. Science, 240: 637-639.

McKnight D. M., Kimball B. A. and Runkel R. L., 2001. pH Dependence of Iron Photoreduction in a Rocky Mountain Stream Affected by Acid Mine Drainage. Hydrological Processes, 15(10): 1979-1992.

Nimick, D.A., 2003. Diurnal Variation in Trace-Metal Concentrations in Streams: U.S. Geological Survey Fact Sheet FS-086-03, 4 pp.

Nimick, D.A., Cleasby, T.E. and McCleskey, R.B., 2005. Seasonality of Diel Cycles of Dissolved Trace-Metal Concentrations in a Rocky Mountain Stream. Environmental Geology, 47: 603-614.

Nimick, D.A., Gammons, C.H., Cleasby, T.E., Madison, J.P., Skaar, D. and Brick, C.M., 2003. Diel Cycles in Dissolved Metal Concentrations in Streams: Occurrence and Possible Causes. Water Resources Research, 39: 1247-1264.

Nimick, D.A., Gammons, C.H. and Parker, S.R., 2011. Diel Biogeochemical Processes and Their Effect on the Aqueous Chemistry of Streams: A Review. Chemical Geology, 283: 3-17.

Nimick, D.A., Moore, J.N., Dalby, C.E. and Savka, M.W., 1998. The Fate of Geothermal Arsenic in the Madison and Missouri Rivers, Montana and Wyoming. Water Resources Research, 34(11): 3051-3067.

Parida, K.M., Gorai, B., Das, N.N. and Rao, S.B., 1997. Studies on Ferric Oxide Hydroxides: III. Adsorption of Selenite $\left(\mathrm{SeO}_{3}{ }^{2-}\right)$ on Different Forms of Iron Oxyhydroxides. Journal of Colloid and Interface Science, 185(2): 355-362.

Parker, S.R., Gammons, C.H., Jones, C.A. and Nimick, D.A., 2007. Role of Hydrous Iron Oxide Formation in Attenuation and Diel Cycling of Dissolved Trace Metals in a Stream Affected by Acid Rock Drainage. Water, Air, \& Soil Pollution, 181: 247-263.

Reddy, K.R. and DeLaune, R.D., 2008. Biogeochemistry of Wetlands: Science and Applications. CRC Press, Boca Raton, Florida, 495 pp.

Rovira, M., Gimenez, J., Martinez, M., Martinez-Llado, X., Pablo, J.d., Marti, V. and Duro, L., 2008. Sorption of Selenium(IV) and Selenium(VI) onto Natural Iron Oxides: Geothite and Hematite. Journal of Hazardous Materials, 150: 279-284.

Schroder, J.L. and Zhang, H., 2009. Using the Multimode Sample Introduction System (MSIS) for Low Level Analysis of Arsenic and Selenium in Water. Soil Science Society of America Journal, 73: 1804-1807.

Schwertmann, U., 1991. Solubility and Dissolution of Iron Oxides. Plant and Soil, 130: 1-25. 
Schwertmann, U. and Cornell, R.M., 2007. Iron Oxides in the Laboratory: Preparation and Characterization. Wiley-VCH Verlag GmbH, D-69469 Weinheim, 90-94 pp.

Sparks, D.L., 2003. Environmental Soil Chemistry, Second Edition. Elsevier Science, USA, 144 pp.

Stookey, L.L., 1970. Ferrozine - A New Spectrophotometric Reagent for Iron. Analytical Chemistry, 42(7): 779-781.

Stumm, W. and Morgan, J.J., 1996. Aquatic Chemistry, Chemical Equilibria and Rates in Natural Waters, 3rd ed. John Wiley \& Sons, Inc., New York.

Torres, J., Pintos, V., Gonzatto, L., Dominguez, S., Kremer, C. and Kremer, E., 2011. Selenium Chemical Speciation in Natural Waters: Protonation and Complexation Behavior of Selenite and Selenate in the Presence of Environmentally Relevant Cations. Chemical Geology, 288: 32-38.

United States Environmental Protection Agency, 2013. Aquatic Life Criteria Table. Updated 12/3/2014, Accessed 3/20/2015. http://water.epa.gov/scitech/swguidance/standards/

criteria/current/index.cfm

Vesper, D., Waltemyer, K., McDonald, L. 2015. Selenium Diel Cycling and Sorption Kinetics. OSMRE-WV ADTI Cooperative Agreement S14AC20009, 32-34 pp.

Wakao, N. and Shiota, H., 1982. Effect of Temperature on the Bacterial Iron Oxidation Rate in a River Contaminated with Acid Mine Water. Journal of General and Applied Microbiology, 28: 465-467.

Younger, P.L., Banwart, S.A. and Hedin, R.S., 2002. Mine Water: Hydrology, Pollution, Remediation. Kluwer Academic Publishers, Norwell, Massachusetts, 65-73 pp.

Zhao, J., Huggins, F.E., Feng, Z. and Huffman, G.P., 1994. Ferrihydrite: Surface Structure and its Effects on Phase Transformation. Clays and Clay Minerals, 42(6): 737-746. 
APPENDICES 


\section{Appendix A. X-ray diffraction (XRD) results}

Measurement Conditions:

Dataset Name

File name

Comment

Creation date $=11 / 26 / 2002$

2Theta:0.001; Minimum step size Omega:0.001

Sample stage $=$ PW3071/xx Bracket

Diffractometer system $=$ XPERT-PRO

Measurement program=EKH_Ferrihydrite, Owner=User-1,

Creation date $=8 / 28 / 2014$ 1:50:38 PM

Measurement Date / Time

Operator

Raw Data Origin

Scan Axis

Start Position [ ${ }^{\circ} 2 \mathrm{Th}$.]

End Position [ $\left.{ }^{\circ} 2 \mathrm{Th}.\right]$

Step Size [ ${ }^{\circ}$ Th.]

Scan Step Time [s]

Scan Type

Offset [ ${ }^{\circ} 2 \mathrm{Th}$.]

Divergence Slit Type

Divergence Slit Size [ $\left.{ }^{\circ}\right]$

Specimen Length [mm]

Receiving Slit Size [mm]

Measurement Temperature $\left[{ }^{\circ} \mathrm{C}\right.$

Anode Material

K-Alpha1 [̊]

K-Alpha2 [̊]

K-Beta $[\AA]$

8/28/2014 1:53:24 PM

xrd

XRD measurement (*.XRDML)

Gonio

15.0000

90.0000

0.0200

30.0000

Pre-set time

0.0000

Fixed

0.9570

10.00

3.0300

$\mathrm{Cu}$

1.54060

1.54443

1.39225

K-A2 / K-A1 Ratio

Generator Settings

0.50000

Diffractometer Type

$40 \mathrm{~mA}, 45 \mathrm{kV}$

Diffractometer Number

0000000013030095

Goniometer Radius [mm]

0

Dist. Focus-Diverg. Slit [mm]

Incident Beam Monochromator

Spinning

No

No 
Main Graphics, Analyze View:

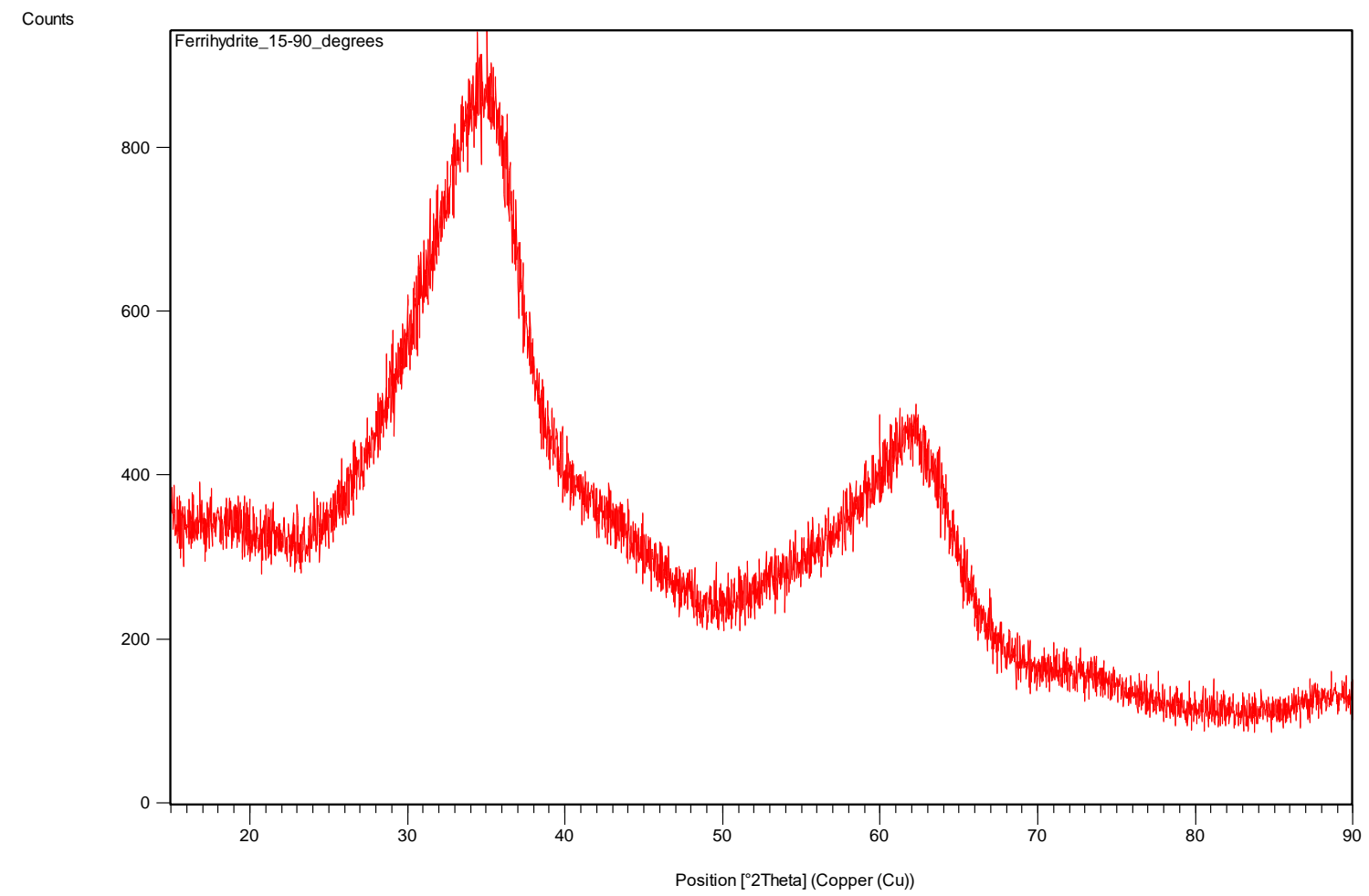

Comments from the XRD technician:

Both samples showed patterns that would generally be considered amorphous. We did a wider range run on one of them - I've attached the report - and it matches pretty well to one of two high areas (they're not really peaks) of 2-line ferrihydrite. The second area is offset in the sample. The scan was a 24-hour scan so it's unlikely that peaks were there but not showing up as can sometimes happen. I can run a wider range scan on the sample labeled B1 if you would like and see if it matches the 2-line ferrihydrite spectrum better. Right now the scan I have for that is just up to 50 or 60 deg and it shows that same first high amorphous area. 
Appendix B. Filtering Experiment for Fe Analysis

Data

\begin{tabular}{|c|c|c|c|c|}
\hline $\begin{array}{c}\text { Vessel } \\
\text { No. } \\
\end{array}$ & $\begin{array}{c}\text { Unfiltered } \\
\text { Fe }^{\text {II }} \\
(\mathrm{mg} / \mathrm{L}) \\
\end{array}$ & 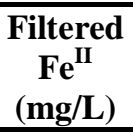 & $\begin{array}{c}\text { Unfiltered } \\
\text { Fe(total) } \\
(\mathrm{mg} / \mathrm{L}) \\
\end{array}$ & $\begin{array}{c}\text { Filtered } \\
\text { Fe(total) } \\
(\mathrm{mg} / \mathrm{L}) \\
\end{array}$ \\
\hline \multirow{6}{*}{$\begin{array}{l}\bar{D} \\
\overline{D_{2}} \\
\dot{0}\end{array}$} & 0.27 & 0.15 & 0.77 & 0.63 \\
\hline & 0.26 & 0.15 & 0.75 & 0.65 \\
\hline & 0.26 & 0.13 & 0.78 & 0.65 \\
\hline & 0.24 & 0.15 & 0.75 & 0.65 \\
\hline & 0.24 & 0.15 & 0.75 & 0.64 \\
\hline & 0.24 & 0.16 & 0.75 & 0.64 \\
\hline \multirow{6}{*}{ 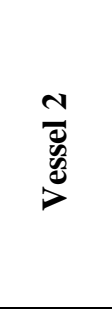 } & 0.23 & 0.13 & 0.51 & 0.46 \\
\hline & 0.19 & 0.13 & 0.51 & 0.44 \\
\hline & 0.22 & 0.13 & 0.53 & 0.43 \\
\hline & 0.19 & 0.13 & 0.51 & 0.44 \\
\hline & 0.20 & 0.13 & 0.56 & 0.46 \\
\hline & 0.20 & 0.12 & 0.53 & 0.46 \\
\hline \multirow{6}{*}{$\begin{array}{l}m \\
\text { m } \\
0 \\
0 \\
0\end{array}$} & 0.23 & 0.20 & 0.60 & 0.48 \\
\hline & 0.23 & 0.15 & 0.60 & 0.48 \\
\hline & 0.23 & 0.15 & 0.60 & 0.48 \\
\hline & 0.24 & 0.15 & 0.60 & 0.48 \\
\hline & 0.23 & 0.15 & 0.60 & 0.48 \\
\hline & 0.23 & 0.15 & 0.60 & 0.50 \\
\hline \multirow{6}{*}{ 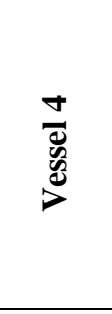 } & 0.28 & 0.17 & 0.64 & 0.46 \\
\hline & 0.27 & 0.16 & 0.64 & 0.46 \\
\hline & 0.26 & 0.16 & 0.64 & 0.47 \\
\hline & 0.26 & 0.16 & 0.64 & 0.47 \\
\hline & 0.27 & 0.16 & 0.64 & 0.47 \\
\hline & 0.27 & 0.16 & 0.64 & 0.48 \\
\hline \multirow{6}{*}{ 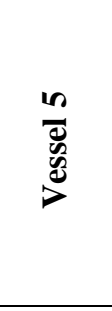 } & 0.23 & 0.15 & 0.37 & 0.27 \\
\hline & 0.24 & 0.15 & 0.43 & 0.27 \\
\hline & 0.23 & 0.15 & 0.39 & 0.26 \\
\hline & 0.23 & 0.16 & 0.40 & 0.27 \\
\hline & 0.23 & 0.16 & 0.43 & 0.27 \\
\hline & 0.23 & 0.15 & 0.37 & 0.27 \\
\hline \multirow{6}{*}{$\begin{array}{l}0 \\
\overline{0} \\
0 \\
0 \\
0\end{array}$} & 0.51 & 0.16 & 0.60 & 0.19 \\
\hline & 0.51 & 0.16 & 0.60 & 0.20 \\
\hline & 0.51 & 0.16 & 0.60 & 0.19 \\
\hline & 0.51 & 0.16 & 0.61 & 0.19 \\
\hline & 0.51 & 0.16 & 0.61 & 0.20 \\
\hline & 0.51 & 0.16 & 0.60 & 0.19 \\
\hline
\end{tabular}




\section{$\underline{\text { Appendix C. Diel Cycle Data }}$}

Appendix C-1. Cycle 1 (7/22/2014) Data

\begin{tabular}{|c|c|c|c|c|c|c|c|c|c|}
\hline & $\begin{array}{c}\text { Sample } \\
\text { No. } \\
\end{array}$ & $\begin{array}{c}\text { Sample } \\
\text { Name }\end{array}$ & $\begin{array}{c}\text { Elapsed time } \\
(\mathbf{h r})\end{array}$ & $\begin{array}{c}\text { Temp. }^{+} \\
\left({ }^{\circ} \mathrm{C}\right) \\
\end{array}$ & $\mathbf{p H}^{+}$ & $\begin{array}{c}\text { Light } \\
\text { (on/off) }\end{array}$ & $\begin{array}{c}\text { Light intensity }^{++} \\
(\text {Lux })\end{array}$ & $\begin{array}{c}\mathrm{Fe}^{\mathrm{II} *} \\
(\mathrm{mg} / \mathrm{L})\end{array}$ & $\begin{array}{c}\mathrm{Fe}(\text { total }) \\
(\mathrm{mg} / \mathrm{L}) \\
\end{array}$ \\
\hline \multirow{22}{*}{$\begin{array}{l}= \\
\bar{d} \\
\overline{8} \\
8\end{array}$} & 1 & V1 - 1 & 0 & 21.5 & 3.15 & off & 0 & $<0.02^{\mathrm{x}}$ & $<0.02^{\mathrm{x}}$ \\
\hline & 2 & V1 - 2 & 1 & 21.0 & 3.15 & off & 0 & $<0.02^{\mathrm{x}}$ & $<0.02^{\mathrm{x}}$ \\
\hline & 3 & V1 - 3 & 2 & 21.2 & 3.06 & on & 3961.1 & $<0.02^{\mathrm{x}}$ & $<0.02^{\mathrm{x}}$ \\
\hline & 4 & V1 - 4 & 3 & 21.4 & 3.07 & on & 4133.4 & $<0.02^{\mathrm{x}}$ & $<0.02^{\mathrm{x}}$ \\
\hline & 5 & V1 - 5 & 4 & 21.7 & 3.08 & on & 4477.8 & $<0.02^{\mathrm{x}}$ & $<0.02^{\mathrm{x}}$ \\
\hline & 6 & V1 - 6 & 5 & 21.8 & 3.08 & on & 4305.6 & $<0.02^{\mathrm{x}}$ & 0.023 \\
\hline & 7 & V1 - 7 & 6 & 21.9 & 3.05 & on & 3961.1 & $<0.02^{\mathrm{x}}$ & $<0.02^{\mathrm{x}}$ \\
\hline & 8 & V1 - 8 & 7 & 22.0 & 3.03 & on & 4650.0 & $<0.02^{\mathrm{x}}$ & 0.075 \\
\hline & 9 & V1 - 9 & 8 & 22.0 & 3.05 & on & 4133.4 & $<0.02^{\mathrm{x}}$ & 0.023 \\
\hline & 10 & V1 - 10 & 9 & 22.1 & 3.04 & on & 4305.6 & $<0.02^{\mathrm{x}}$ & 0.075 \\
\hline & 11 & V1 - 11 & 10 & 22.1 & 3.04 & on & 4477.8 & $<0.02^{\mathrm{x}}$ & 0.075 \\
\hline & 12 & V1 - 12 & 11 & 22.1 & 3.06 & on & 3961.1 & $<0.02^{\mathrm{x}}$ & 0.092 \\
\hline & 13 & V1 - 13 & 12 & 21.8 & 3.06 & off & 0 & $<0.02^{\mathrm{x}}$ & 0.075 \\
\hline & 14 & V1 - 14 & 13 & 21.5 & 3.07 & off & 0 & $<0.02^{\mathrm{x}}$ & 0.11 \\
\hline & 15 & V1 - 15 & 14 & 21.2 & 3.07 & off & 0 & $<0.02^{\mathrm{x}}$ & 0.13 \\
\hline & 16 & V1 - 16 & 15 & 21.1 & 3.06 & off & 0 & $<0.02^{\mathrm{x}}$ & 0.13 \\
\hline & 17 & V1 - 17 & 16 & 21.0 & 3.07 & off & 0 & $<0.02^{\mathrm{x}}$ & 0.11 \\
\hline & 18 & V1 - 18 & 17 & 20.9 & 3.06 & off & 0 & $<0.02^{x}$ & 0.14 \\
\hline & 19 & V1 - 19 & 18 & 20.9 & 3.08 & off & 0 & $<0.02^{\mathrm{x}}$ & 0.13 \\
\hline & 20 & V1 - 20 & 19 & 20.9 & 3.07 & off & 0 & $<0.02^{\mathrm{x}}$ & 0.14 \\
\hline & 21 & V1 - 21 & 20 & 21.2 & 3.05 & on & 4133.4 & $<0.02^{\mathrm{x}}$ & 0.16 \\
\hline & 22 & V1 - 22 & 21 & 21.5 & 3.09 & on & 4133.4 & $<0.02^{\mathrm{x}}$ & 0.23 \\
\hline
\end{tabular}


Appendix C-2. Cycle 2 (10/17-18/2014) Data

\begin{tabular}{|c|c|c|c|c|c|c|c|c|c|}
\hline & $\begin{array}{c}\text { Sample } \\
\text { No. }\end{array}$ & $\begin{array}{c}\text { Sample } \\
\text { Name }\end{array}$ & $\begin{array}{c}\text { Elapsed time } \\
(\mathrm{hr})\end{array}$ & $\begin{array}{c}\text { Temp. }^{+} \\
\left({ }^{\circ} \mathrm{C}\right)\end{array}$ & $\mathbf{p H}^{+}$ & $\begin{array}{c}\text { Light } \\
\text { (on/off) }\end{array}$ & $\begin{array}{c}\text { Light intensity }^{++} \\
\text {(Lux) }\end{array}$ & $\begin{array}{c}\mathrm{Fe}^{\mathrm{II}^{*}} \\
(\mathrm{mg} / \mathrm{L})\end{array}$ & $\begin{array}{r}\mathrm{Fe}(\text { total }) \\
(\mathrm{mg} / \mathrm{L})\end{array}$ \\
\hline \multirow{32}{*}{$\begin{array}{l}\bar{D} \\
\overline{0} \\
0 \\
\end{array}$} & 1 & $\mathrm{~V} 1-1 \mathrm{a}$ & 0 & 25.0 & 2.98 & off & 0 & 0.077 & 0.51 \\
\hline & 2 & $\mathrm{~V} 1-1 \mathrm{~b}$ & 0 & 25.0 & 2.98 & off & 0 & 0.15 & 0.50 \\
\hline & 3 & V1 - 1c & 0 & 25.0 & 2.98 & off & 0 & 0.077 & 0.51 \\
\hline & 4 & V1 - 2 & 1 & 24.5 & 2.98 & off & 0 & 0.048 & 0.47 \\
\hline & 5 & V1 - 3 & 2 & 24.4 & 2.99 & off & 0 & 0.048 & 0.47 \\
\hline & 6 & V1 - 4 & 3 & 24.8 & 2.99 & on & 3702.8 & 0.063 & 0.47 \\
\hline & 7 & V1 - 5 & 4 & 24.7 & 2.98 & on & 3961.1 & 0.077 & 0.47 \\
\hline & 8 & V1 - 6 & 5 & 24.9 & 2.99 & on & 3961.1 & 0.077 & 0.46 \\
\hline & 9 & $\mathrm{~V} 1-7 \mathrm{a}$ & 6 & 25.0 & 2.98 & on & 3616.7 & 0.11 & 0.47 \\
\hline & 10 & $\mathrm{~V} 1-7 \mathrm{~b}$ & 6 & 25.0 & 2.98 & on & 3616.7 & 0.11 & 0.46 \\
\hline & 11 & $\mathrm{~V} 1-7 \mathrm{c}$ & 6 & 25.0 & 2.98 & on & 3616.7 & 0.11 & 0.47 \\
\hline & 12 & V1 - 8 & 7 & 24.9 & 3.00 & on & 3788.9 & 0.091 & 0.46 \\
\hline & 13 & V1 - 9 & 8 & 25.0 & 3.00 & on & 3961.1 & 0.091 & 0.47 \\
\hline & 14 & V1 - 10 & 9 & 24.8 & 2.97 & on & 3702.8 & 0.077 & 0.46 \\
\hline & 15 & V1 - 11 & 10 & 25.0 & 2.98 & on & 3875.0 & 0.091 & 0.46 \\
\hline & 16 & V1 - 12 & 11 & 25.0 & 2.96 & on & 3875.0 & 0.048 & 0.47 \\
\hline & 17 & $\mathrm{~V} 1-13 \mathrm{a}$ & 12 & 24.9 & 2.96 & on & 3875.0 & 0.091 & 0.46 \\
\hline & 18 & $\mathrm{~V} 1-13 b$ & 12 & 24.9 & 2.96 & on & 3875.0 & 0.091 & 0.47 \\
\hline & 19 & $V 1-13 c$ & 12 & 24.9 & 2.96 & on & 3875.0 & 0.11 & 0.46 \\
\hline & 20 & V1 - 14 & 13 & 24.7 & 2.98 & on & 3961.1 & 0.091 & 0.46 \\
\hline & 21 & V1 - 15 & 14 & 24.6 & 2.98 & on & 3616.7 & 0.23 & 0.46 \\
\hline & 22 & V1 - 16 & 15 & 24.4 & 2.98 & off & 0 & 0.23 & 0.44 \\
\hline & 23 & V1 - 17 & 16 & 24.3 & 2.98 & off & 0 & 0.23 & 0.44 \\
\hline & 24 & V1 - 18 & 17 & 24.3 & 2.98 & off & 0 & 0.22 & 0.43 \\
\hline & 25 & $\mathrm{~V} 1-19 \mathrm{a}$ & 18 & 24.7 & 2.99 & off & 0 & 0.23 & 0.47 \\
\hline & 26 & $V 1-19 b$ & 18 & 24.7 & 2.99 & off & 0 & 0.25 & 0.44 \\
\hline & 27 & $\mathrm{~V} 1-19 \mathrm{c}$ & 18 & 24.7 & 2.99 & off & 0 & 0.23 & 0.44 \\
\hline & 28 & V1 - 20 & 19 & 24.8 & 2.98 & off & 0 & 0.25 & 0.46 \\
\hline & 29 & V1 - 21 & 20 & 24.9 & 2.98 & off & 0 & 0.25 & 0.44 \\
\hline & 30 & V1 - 22 & 21 & 25.1 & 2.98 & off & 0 & 0.22 & 0.44 \\
\hline & 31 & V1 - 23 & 22 & 25.0 & 2.98 & off & 0 & 0.22 & 0.57 \\
\hline & 32 & V1 - 24 & 23 & 25.0 & 2.98 & off & 0 & 0.19 & 0.58 \\
\hline
\end{tabular}


Appendix C-2. Cycle 2 (10/17-18/2014) Data Continued

\begin{tabular}{|c|c|c|c|c|c|c|c|c|c|}
\hline & $\begin{array}{c}\text { Sample } \\
\text { No. }\end{array}$ & $\begin{array}{l}\text { Sample } \\
\text { Name }\end{array}$ & $\begin{array}{c}\text { Elapsed time } \\
(\mathrm{hr})\end{array}$ & $\begin{array}{c}\text { Temp. }^{+} \\
\left({ }^{\circ} \mathrm{C}\right)\end{array}$ & $\mathbf{p H}^{+}$ & $\begin{array}{c}\text { Light } \\
\text { (on/off) }\end{array}$ & $\begin{array}{c}\text { Light intensity }^{++} \\
(\text {Lux })\end{array}$ & $\begin{array}{c}\mathrm{Fe}^{\mathrm{II*}} \\
(\mathrm{mg} / \mathrm{L})\end{array}$ & $\begin{array}{c}\mathrm{Fe}(\text { total }) \\
(\mathrm{mg} / \mathrm{L})\end{array}$ \\
\hline \multirow{11}{*}{ 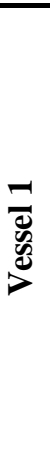 } & 33 & $\mathrm{~V} 1-25 \mathrm{a}$ & 24 & 25.0 & 2.98 & off & 0 & 0.20 & 0.56 \\
\hline & 34 & $\mathrm{~V} 1-25 \mathrm{~b}$ & 24 & 25.0 & 2.98 & off & 0 & 0.20 & 0.57 \\
\hline & 35 & $\mathrm{~V} 1-25 \mathrm{c}$ & 24 & 25.0 & 2.98 & off & 0 & 0.20 & 0.56 \\
\hline & 36 & V1 - 26 & 25 & 24.9 & 2.99 & off & 0 & 0.20 & 0.57 \\
\hline & 37 & V1 - 27 & 26 & 24.9 & 2.98 & off & 0 & 0.19 & 0.57 \\
\hline & 38 & V1 - 28 & 27 & 24.8 & 2.98 & on & 3616.7 & 0.19 & 0.58 \\
\hline & 39 & V1 - 29 & 28 & 24.8 & 2.96 & on & 3401.5 & 0.20 & 0.58 \\
\hline & 40 & V1 - 30 & 29 & 24.8 & 2.97 & on & 3530.6 & 0.20 & 0.58 \\
\hline & 41 & $\mathrm{~V} 1-31 \mathrm{a}$ & 30 & 24.8 & 2.99 & on & 3702.8 & 0.18 & 0.60 \\
\hline & 42 & $\mathrm{~V} 1-31 \mathrm{~b}$ & 30 & 24.8 & 2.99 & on & 3702.8 & 0.18 & 0.60 \\
\hline & 43 & $\mathrm{~V} 1-31 \mathrm{c}$ & 30 & 24.8 & 2.99 & on & 3702.8 & 0.19 & 0.60 \\
\hline \multirow{21}{*}{ 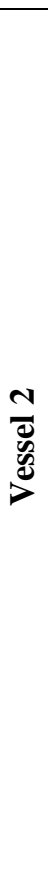 } & 44 & $\mathrm{~V} 2-1 \mathrm{a}$ & 0 & 24.0 & 2.95 & off & 0 & 0.077 & 0.71 \\
\hline & 45 & $\mathrm{~V} 2-1 \mathrm{~b}$ & 0 & 24.0 & 2.95 & off & 0 & 0.077 & 0.71 \\
\hline & 46 & $\mathrm{~V} 2-1 \mathrm{c}$ & 0 & 24.0 & 2.95 & off & 0 & 0.091 & 0.71 \\
\hline & 47 & $\mathrm{~V} 2-2$ & 1 & 23.4 & 2.94 & off & 0 & 0.077 & 0.71 \\
\hline & 48 & $\mathrm{~V} 2-3$ & 2 & 23.3 & 2.96 & off & 0 & 0.077 & 0.68 \\
\hline & 49 & V2 - 4 & 3 & 24.4 & 2.94 & on & 3702.8 & 0.11 & 0.70 \\
\hline & 50 & $V 2-5$ & 4 & 24.7 & 2.96 & on & 3961.1 & 0.15 & 0.70 \\
\hline & 51 & $v 2-6$ & 5 & 24.8 & 2.93 & on & 3961.1 & 0.16 & 0.68 \\
\hline & 52 & $\mathrm{~V} 2-7 \mathrm{a}$ & 6 & 24.9 & 2.93 & on & 3616.7 & 0.20 & 0.70 \\
\hline & 53 & $V 2-7 b$ & 6 & 24.9 & 2.93 & on & 3616.7 & 0.19 & 0.71 \\
\hline & 54 & $V 2-7 c$ & 6 & 24.9 & 2.93 & on & 3616.7 & 0.20 & 0.71 \\
\hline & 55 & $V 2-8$ & 7 & 24.8 & 2.96 & on & 3788.9 & 0.19 & 0.71 \\
\hline & 56 & $\mathrm{~V} 2-9$ & 8 & 24.8 & 2.96 & on & 3961.1 & 0.22 & 0.71 \\
\hline & 57 & V2 - 10 & 9 & 24.6 & 2.96 & on & 3702.8 & 0.22 & 0.76 \\
\hline & 58 & $\mathrm{~V} 2-11$ & 10 & 25.0 & 2.93 & on & 3875.0 & 0.22 & 0.73 \\
\hline & 59 & $\mathrm{~V} 2-12$ & 11 & 24.8 & 2.96 & on & 3875.0 & 0.20 & 0.74 \\
\hline & 60 & $\mathrm{~V} 2-13 \mathrm{a}$ & 12 & 24.5 & 2.93 & on & 3875.0 & 0.22 & 0.73 \\
\hline & 61 & $V 2-13 b$ & 12 & 24.5 & 2.93 & on & 3875.0 & 0.22 & 0.73 \\
\hline & 62 & $V 2-13 c$ & 12 & 24.5 & 2.93 & on & 3875.0 & 0.23 & 0.74 \\
\hline & 63 & $\mathrm{~V} 2-14$ & 13 & 24.7 & 2.96 & on & 3961.1 & 0.23 & 0.77 \\
\hline & 64 & $\mathrm{~V} 2-15$ & 14 & 24.7 & 2.95 & on & 3616.7 & 0.37 & 0.74 \\
\hline
\end{tabular}


Appendix C-2. Cycle 2 (10/17-18/2014) Data Continued

\begin{tabular}{|c|c|c|c|c|c|c|c|c|c|}
\hline & $\begin{array}{c}\text { Sample } \\
\text { No. }\end{array}$ & $\begin{array}{l}\text { Sample } \\
\text { Name }\end{array}$ & $\begin{array}{c}\text { Elapsed time } \\
(\mathrm{hr})\end{array}$ & $\begin{array}{c}\text { Temp. }^{+} \\
\left({ }^{\circ} \mathrm{C}\right)\end{array}$ & $\mathbf{p H}^{+}$ & $\begin{array}{c}\text { Light } \\
\text { (on/off) }\end{array}$ & $\begin{array}{c}\text { Light intensity }^{++} \\
(\text {Lux })\end{array}$ & $\begin{array}{c}\mathrm{Fe}^{\mathrm{II*}} \\
(\mathrm{mg} / \mathrm{L})\end{array}$ & $\begin{array}{c}\mathrm{Fe}(\text { total }) \\
(\mathrm{mg} / \mathrm{L})\end{array}$ \\
\hline \multirow{22}{*}{$\begin{array}{l}\frac{N}{d} \\
\frac{0}{2} \\
>\end{array}$} & 65 & $\mathrm{~V} 2-16$ & 15 & 24.4 & 2.95 & off & 0 & 0.37 & 0.71 \\
\hline & 66 & $\mathrm{~V} 2-17$ & 16 & 24.7 & 2.95 & off & 0 & 0.39 & 0.71 \\
\hline & 67 & $\mathrm{~V} 2-18$ & 17 & 24.6 & 2.94 & off & 0 & 0.36 & 0.71 \\
\hline & 68 & $\mathrm{~V} 2-19 \mathrm{a}$ & 18 & 24.7 & 2.95 & off & 0 & 0.37 & 0.74 \\
\hline & 69 & $V 2-19 b$ & 18 & 24.7 & 2.95 & off & 0 & 0.39 & 0.74 \\
\hline & 70 & $V 2-19 c$ & 18 & 24.7 & 2.95 & off & 0 & 0.37 & 0.73 \\
\hline & 71 & $\mathrm{~V} 2-20$ & 19 & 25.2 & 2.95 & off & 0 & 0.39 & 0.74 \\
\hline & 72 & $\mathrm{~V} 2-21$ & 20 & 25.2 & 2.95 & off & 0 & 0.37 & 0.77 \\
\hline & 73 & $\mathrm{~V} 2-22$ & 21 & 25.3 & 2.95 & off & 0 & 0.37 & 0.74 \\
\hline & 74 & $V 2-23$ & 22 & 25.0 & 2.95 & off & 0 & 0.36 & 0.87 \\
\hline & 75 & $\mathrm{~V} 2-24$ & 23 & 24.9 & 2.95 & off & 0 & 0.33 & 0.88 \\
\hline & 76 & $\mathrm{~V} 2-25 \mathrm{a}$ & 24 & 25.1 & 2.94 & off & 0 & 0.34 & 0.87 \\
\hline & 77 & $V 2-25 b$ & 24 & 25.1 & 2.94 & off & 0 & 0.34 & 0.87 \\
\hline & 78 & $V 2-25 c$ & 24 & 25.1 & 2.94 & off & 0 & 0.36 & 0.87 \\
\hline & 79 & V2 - 26 & 25 & 25.2 & 2.94 & off & 0 & 0.34 & 0.88 \\
\hline & 80 & V2 - 27 & 26 & 25.0 & 2.95 & off & 0 & 0.34 & 0.87 \\
\hline & 81 & V2 - 28 & 27 & 25.1 & 2.96 & on & 3616.7 & 0.36 & 0.88 \\
\hline & 82 & V2 - 29 & 28 & 25.1 & 2.93 & on & 3401.5 & 0.36 & 0.90 \\
\hline & 83 & $\mathrm{~V} 2-30$ & 29 & 25.1 & 2.96 & on & 3530.6 & 0.36 & 0.91 \\
\hline & 84 & $\mathrm{~V} 2-31 \mathrm{a}$ & 30 & 25.0 & 2.93 & on & 3702.8 & 0.34 & 0.91 \\
\hline & 85 & $\mathrm{~V} 2-31 \mathrm{~b}$ & 30 & 25.0 & 2.93 & on & 3702.8 & 0.34 & 0.91 \\
\hline & 86 & $\mathrm{~V} 2-31 \mathrm{c}$ & 30 & 25.0 & 2.93 & on & 3702.8 & 0.36 & 0.90 \\
\hline \multirow{10}{*}{$\begin{array}{l}m \\
\bar{d} \\
\tilde{E} \\
D\end{array}$} & 87 & $\mathrm{~V} 3-1 \mathrm{a}$ & 0 & 23.4 & 2.87 & off & 0 & 0.063 & 0.77 \\
\hline & 88 & $V 3-1 b$ & 0 & 23.4 & 2.87 & off & 0 & 0.077 & 0.73 \\
\hline & 89 & $\mathrm{~V} 3-1 \mathrm{c}$ & 0 & 23.4 & 2.87 & off & 0 & 0.063 & 0.74 \\
\hline & 90 & V3 - 2 & 1 & 24.0 & 2.87 & off & 0 & 0.063 & 0.76 \\
\hline & 91 & V3 - 3 & 2 & 24.7 & 2.86 & off & 0 & 0.063 & 0.77 \\
\hline & 92 & V3 - 4 & 3 & 24.8 & 2.87 & on & 3702.8 & 0.091 & 0.81 \\
\hline & 93 & V3 - 5 & 4 & 24.8 & 2.89 & on & 3961.1 & 0.091 & 0.85 \\
\hline & 94 & V3 - 6 & 5 & 24.6 & 2.89 & on & 3961.1 & 0.11 & 0.87 \\
\hline & 95 & $V 3-7 a$ & 6 & 24.4 & 2.89 & on & 3616.7 & 0.11 & 0.90 \\
\hline & 96 & $\mathrm{~V} 3-7 \mathrm{~b}$ & 6 & 24.4 & 2.89 & on & 3616.7 & 0.11 & 0.90 \\
\hline
\end{tabular}


Appendix C-2. Cycle 2 (10/17-18/2014) Data Continued

\begin{tabular}{|c|c|c|c|c|c|c|c|c|c|}
\hline & $\begin{array}{c}\text { Sample } \\
\text { No. } \\
\end{array}$ & $\begin{array}{c}\text { Sample } \\
\text { Name } \\
\end{array}$ & $\begin{array}{c}\text { Elapsed time } \\
(\mathrm{hr})\end{array}$ & $\begin{array}{c}\text { Temp. }^{+} \\
\left({ }^{\circ} \mathrm{C}\right)\end{array}$ & $\mathbf{p H}^{+}$ & $\begin{array}{c}\text { Light } \\
\text { (on/off) } \\
\end{array}$ & $\begin{array}{c}\text { Light intensity }^{++} \\
\text {(Lux) }\end{array}$ & $\begin{array}{c}\mathrm{Fe}^{\mathrm{II} *} \\
(\mathrm{mg} / \mathrm{L}) \\
\end{array}$ & $\begin{array}{c}\mathrm{Fe}(\text { total }) \\
(\mathrm{mg} / \mathrm{L}) \\
\end{array}$ \\
\hline \multirow{32}{*}{ 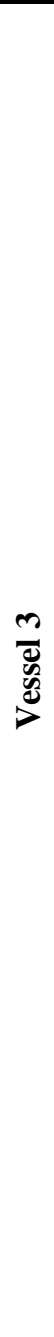 } & 97 & $\mathrm{~V} 3-7 \mathrm{c}$ & 6 & 24.4 & 2.89 & on & 3616.7 & 0.11 & 0.90 \\
\hline & 98 & $\mathrm{~V} 3-8$ & 7 & 24.7 & 2.90 & on & 3788.9 & 0.091 & 0.90 \\
\hline & 99 & V3 - 9 & 8 & 24.3 & 2.90 & on & 3961.1 & 0.11 & 0.93 \\
\hline & 100 & $\mathrm{~V} 3-10$ & 9 & 24.6 & 2.89 & on & 3702.8 & 0.091 & 0.97 \\
\hline & 101 & V3 - 11 & 10 & 24.4 & 2.89 & on & 3875.0 & 0.091 & 0.98 \\
\hline & 102 & $V 3-12$ & 11 & 24.4 & 2.88 & on & 3875.0 & $<0.02^{\mathrm{x}}$ & 1.0 \\
\hline & 103 & $\mathrm{~V} 3-13 \mathrm{a}$ & 12 & 24.0 & 2.89 & on & 3875.0 & 0.091 & 1.0 \\
\hline & 104 & $\mathrm{~V} 3-13 \mathrm{~b}$ & 12 & 24.0 & 2.89 & on & 3875.0 & 0.11 & 1.0 \\
\hline & 105 & $\mathrm{~V} 3-13 \mathrm{c}$ & 12 & 24.0 & 2.89 & on & 3875.0 & 0.11 & 0.98 \\
\hline & 106 & V3 - 14 & 13 & 24.4 & 2.88 & on & 3961.1 & 0.11 & 1.0 \\
\hline & 107 & V3 - 15 & 14 & 24.3 & 3.13 & on & 3616.7 & 0.29 & 0.84 \\
\hline & 108 & V3 - 16 & 15 & 24.1 & 3.13 & off & 0 & 0.27 & 0.83 \\
\hline & 109 & V3 - 17 & 16 & 23.7 & 3.13 & off & 0 & 0.27 & 0.80 \\
\hline & 110 & V3 - 18 & 17 & 23.4 & 3.13 & off & 0 & 0.25 & 0.77 \\
\hline & 111 & $\mathrm{~V} 3-19 \mathrm{a}$ & 18 & 23.4 & 3.14 & off & 0 & 0.26 & 0.80 \\
\hline & 112 & V3 - 19b & 18 & 23.4 & 3.14 & off & 0 & 0.26 & 0.80 \\
\hline & 113 & $\mathrm{~V} 3-19 \mathrm{c}$ & 18 & 23.4 & 3.14 & off & 0 & 0.26 & 0.80 \\
\hline & 114 & V3 - 20 & 19 & 24.5 & 3.13 & off & 0 & 0.27 & 0.80 \\
\hline & 115 & V3 - 21 & 20 & 24.7 & 3.13 & off & 0 & 0.26 & 0.78 \\
\hline & 116 & V3 - 22 & 21 & 24.7 & 3.13 & off & 0 & 0.25 & 0.77 \\
\hline & 117 & V3 - 23 & 22 & 25.0 & 3.13 & off & 0 & 0.23 & 0.90 \\
\hline & 118 & V3 - 24 & 23 & 25.2 & 3.12 & off & 0 & 0.20 & 0.93 \\
\hline & 119 & $\mathrm{~V} 3-25 \mathrm{a}$ & 24 & 25.1 & 3.13 & off & 0 & 0.23 & 0.88 \\
\hline & 120 & $\mathrm{~V} 3-25 \mathrm{~b}$ & 24 & 25.1 & 3.13 & off & 0 & 0.22 & 0.88 \\
\hline & 121 & $\mathrm{~V} 3-25 \mathrm{c}$ & 24 & 25.1 & 3.13 & off & 0 & 0.22 & 0.88 \\
\hline & 122 & V3 - 26 & 25 & 24.8 & 3.13 & off & 0 & 0.22 & 0.90 \\
\hline & 123 & V3 - 27 & 26 & 24.1 & 3.13 & off & 0 & 0.22 & 0.93 \\
\hline & 124 & V3 - 28 & 27 & 24.5 & 3.14 & on & 3616.7 & 0.22 & 0.88 \\
\hline & 125 & V3 - 29 & 28 & 24.8 & 3.13 & on & 3401.5 & 0.23 & 0.90 \\
\hline & 126 & V3 - 30 & 29 & 24.9 & 3.13 & on & 3530.6 & 0.23 & 0.90 \\
\hline & 127 & $\mathrm{~V} 3-31 \mathrm{a}$ & 30 & 25.0 & 3.13 & on & 3702.8 & 0.22 & 0.90 \\
\hline & 128 & $V 3-31 b$ & 30 & 25.0 & 3.13 & on & 3702.8 & 0.23 & 0.90 \\
\hline
\end{tabular}


Appendix C-2. Cycle 2 (10/17-18/2014) Data Continued

\begin{tabular}{|c|c|c|c|c|c|c|c|c|c|}
\hline & $\begin{array}{c}\text { Sample } \\
\text { No. } \\
\end{array}$ & $\begin{array}{c}\text { Sample } \\
\text { Name } \\
\end{array}$ & $\begin{array}{c}\text { Elapsed time } \\
(\mathrm{hr})\end{array}$ & $\begin{array}{c}\text { Temp. }^{+} \\
\left({ }^{\circ} \mathrm{C}\right)\end{array}$ & $\mathbf{p H}^{+}$ & $\begin{array}{c}\text { Light } \\
\text { (on/off) } \\
\end{array}$ & $\begin{array}{c}\text { Light intensity }^{++} \\
\text {(Lux) }\end{array}$ & $\begin{array}{c}\mathrm{Fe}^{\mathrm{II} *} \\
(\mathrm{mg} / \mathrm{L}) \\
\end{array}$ & $\begin{array}{c}\mathrm{Fe}(\text { total }) \\
(\mathrm{mg} / \mathrm{L}) \\
\end{array}$ \\
\hline V3 & 129 & V3 - 31c & 30 & 25.0 & 3.13 & on & 3702.8 & 0.20 & 0.91 \\
\hline \multirow{31}{*}{ 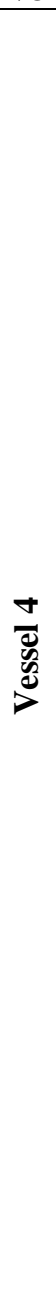 } & 130 & $\mathrm{~V} 4-1 \mathrm{a}$ & 0 & 24.2 & 2.97 & off & 0 & 0.12 & 0.70 \\
\hline & 131 & $V 4-1 b$ & 0 & 24.2 & 2.97 & off & 0 & 0.11 & 0.68 \\
\hline & 132 & V4 - 1c & 0 & 24.2 & 2.97 & off & 0 & 0.11 & 0.68 \\
\hline & 133 & V4 - 2 & 1 & 24.1 & 2.96 & off & 0 & 0.11 & 0.67 \\
\hline & 134 & V4 - 3 & 2 & 24.5 & 2.97 & off & 0 & 0.11 & 0.64 \\
\hline & 135 & V4 - 4 & 3 & 24.8 & 2.97 & on & 3702.8 & 0.13 & 0.66 \\
\hline & 136 & V4 - 5 & 4 & 24.7 & 2.97 & on & 3961.1 & 0.12 & 0.64 \\
\hline & 137 & V4 - 6 & 5 & 24.7 & 2.96 & on & 3961.1 & 0.13 & 0.63 \\
\hline & 138 & $\mathrm{~V} 4-7 \mathrm{a}$ & 6 & 24.7 & 2.97 & on & 3616.7 & 0.13 & 0.64 \\
\hline & 139 & $\mathrm{~V} 4-7 \mathrm{~b}$ & 6 & 24.7 & 2.97 & on & 3616.7 & 0.13 & 0.66 \\
\hline & 140 & $\mathrm{~V} 4-7 \mathrm{c}$ & 6 & 24.7 & 2.97 & on & 3616.7 & 0.15 & 0.71 \\
\hline & 141 & V4 - 8 & 7 & 24.9 & 2.95 & on & 3788.9 & 0.13 & 0.63 \\
\hline & 142 & V4 - 9 & 8 & 24.5 & 2.95 & on & 3961.1 & 0.13 & 0.64 \\
\hline & 143 & V4 - 10 & 9 & 24.6 & 2.96 & on & 3702.8 & 0.16 & 0.64 \\
\hline & 144 & V4 - 11 & 10 & 24.4 & 2.95 & on & 3875.0 & 0.12 & 0.64 \\
\hline & 145 & V4 - 12 & 11 & 24.4 & 2.96 & on & 3875.0 & 0.091 & 0.64 \\
\hline & 146 & $\mathrm{~V} 4-13 \mathrm{a}$ & 12 & 24.0 & 2.98 & on & 3875.0 & 0.13 & 0.61 \\
\hline & 147 & $\mathrm{~V} 4-13 \mathrm{~b}$ & 12 & 24.0 & 2.98 & on & 3875.0 & 0.12 & 0.61 \\
\hline & 148 & $\mathrm{~V} 4-13 \mathrm{c}$ & 12 & 24.0 & 2.98 & on & 3875.0 & 0.12 & 0.63 \\
\hline & 149 & V4 - 14 & 13 & 24.3 & 2.97 & on & 3961.1 & 0.12 & 0.63 \\
\hline & 150 & V4 - 15 & 14 & 24.2 & 2.96 & on & 3616.7 & 0.26 & 0.61 \\
\hline & 151 & V4 - 16 & 15 & 24.0 & 2.96 & off & 0 & 0.26 & 0.58 \\
\hline & 152 & V4 - 17 & 16 & 23.6 & 2.96 & off & 0 & 0.25 & 0.58 \\
\hline & 153 & V4 - 18 & 17 & 23.3 & 2.97 & off & 0 & 0.23 & 0.56 \\
\hline & 154 & $\mathrm{~V} 4-19 \mathrm{a}$ & 18 & 23.2 & 2.97 & off & 0 & 0.26 & 0.58 \\
\hline & 155 & $\mathrm{~V} 4-19 b$ & 18 & 23.2 & 2.97 & off & 0 & 0.26 & 0.58 \\
\hline & 156 & $\mathrm{~V} 4-19 \mathrm{c}$ & 18 & 23.2 & 2.97 & off & 0 & 0.25 & 0.58 \\
\hline & 157 & V4 - 20 & 19 & 24.3 & 2.97 & off & 0 & 0.27 & 0.57 \\
\hline & 158 & V4 - 21 & 20 & 24.5 & 2.97 & off & 0 & 0.25 & 0.58 \\
\hline & 159 & V4 - 22 & 21 & 24.6 & 2.97 & off & 0 & 0.23 & 0.56 \\
\hline & 160 & V4 - 23 & 22 & 24.7 & 2.97 & off & 0 & 0.22 & 0.68 \\
\hline
\end{tabular}


Appendix C-2. Cycle 2 (10/17-18/2014) Data Continued

\begin{tabular}{|c|c|c|c|c|c|c|c|c|c|}
\hline & $\begin{array}{c}\text { Sample } \\
\text { No. }\end{array}$ & $\begin{array}{c}\text { Sample } \\
\text { Name } \\
\end{array}$ & $\begin{array}{c}\text { Elapsed time } \\
(\mathrm{hr})\end{array}$ & $\begin{array}{c}\text { Temp. }^{+} \\
\left({ }^{\circ} \mathrm{C}\right)\end{array}$ & $\mathbf{p H}^{+}$ & $\begin{array}{c}\text { Light } \\
\text { (on/off) }\end{array}$ & $\begin{array}{c}\text { Light intensity }^{++} \\
\text {(Lux) }\end{array}$ & $\begin{array}{c}\mathrm{Fe}^{\mathrm{II}} \\
(\mathrm{mg} / \mathrm{L})\end{array}$ & $\begin{array}{c}\mathrm{Fe}(\text { total }) \\
(\mathrm{mg} / \mathrm{L}) \\
\end{array}$ \\
\hline \multirow{12}{*}{ 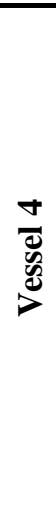 } & 161 & $\mathrm{~V} 4-24$ & 23 & 24.8 & 2.97 & off & 0 & 0.19 & 0.68 \\
\hline & 162 & V4 - 25a & 24 & 24.6 & 2.97 & off & 0 & 0.22 & 0.68 \\
\hline & 163 & V4 - 25b & 24 & 24.6 & 2.97 & off & 0 & 0.20 & 0.68 \\
\hline & 164 & V4 - 25c & 24 & 24.6 & 2.97 & off & 0 & 0.22 & 0.68 \\
\hline & 165 & V4 - 26 & 25 & 24.3 & 2.96 & off & 0 & 0.20 & 0.68 \\
\hline & 166 & V4 - 27 & 26 & 23.7 & 2.97 & off & 0 & 0.20 & 0.67 \\
\hline & 167 & V4 - 28 & 27 & 23.9 & 2.97 & on & 3616.7 & 0.20 & 0.68 \\
\hline & 168 & V4 - 29 & 28 & 24.1 & 2.97 & on & 3401.5 & 0.20 & 0.70 \\
\hline & 169 & V4 - 30 & 29 & 24.3 & 2.97 & on & 3530.6 & 0.20 & 0.70 \\
\hline & 170 & V4 - 31a & 30 & 24.4 & 2.97 & on & 3702.8 & 0.19 & 0.70 \\
\hline & 171 & V4 - 31b & 30 & 24.4 & 2.97 & on & 3702.8 & 0.19 & 0.71 \\
\hline & 172 & V4 - 31c & 30 & 24.4 & 2.97 & on & 3702.8 & 0.19 & 0.71 \\
\hline
\end{tabular}

${ }^{+}$Measured using DrDAQ PicoLog Recorder

${ }^{++}$Measured using HOBO Pendant Light/Temperature Loggers

* Samples analyzed using HACH DR2800 Spectrophotometer

${ }^{x}$ Sample below ferrozine MDL of $0.02 \mathrm{mg} / \mathrm{L}$ for $\mathrm{Fe}^{\mathrm{II}}$ and $\mathrm{Fe}$ (total)

Sample names including a,b,c are triplicate samples 
Appendix C-3. Cycle 3 (10/25/2014) Data

\begin{tabular}{|c|c|c|c|c|c|c|c|c|c|}
\hline & $\begin{array}{c}\text { Sample } \\
\text { No. }\end{array}$ & $\begin{array}{c}\text { Sample } \\
\text { Name }\end{array}$ & $\begin{array}{l}\text { Elapsed time } \\
(\mathrm{hr})\end{array}$ & $\begin{array}{c}\text { Temp. }^{+} \\
\left({ }^{\circ} \mathrm{C}\right)\end{array}$ & $\mathbf{p H}^{+}$ & $\begin{array}{c}\text { Light } \\
\text { (on/off) }\end{array}$ & $\begin{array}{c}\mathrm{Fe}^{\mathrm{II*}} \\
(\mathrm{mg} / \mathrm{L})\end{array}$ & $\begin{array}{c}\mathrm{Fe}(\text { total })^{*} \\
(\mathrm{mg} / \mathrm{L})\end{array}$ & $\begin{array}{l}\mathrm{Se}^{\mathrm{IV**}} \\
(\mu \mathrm{g} / \mathrm{L})\end{array}$ \\
\hline \multirow{17}{*}{\begin{tabular}{l}
$\bar{D}$ \\
$\overline{0}$ \\
\multirow{2}{*}{} \\
$>$
\end{tabular}} & 1 & $\mathrm{~V} 1-1 \mathrm{a}$ & 0 & 25.5 & 2.97 & off & 0.048 & 0.51 & 126.0 \\
\hline & 2 & $\mathrm{~V} 1-1 \mathrm{~b}$ & 0 & 25.5 & 2.97 & off & 0.048 & 0.51 & 129.6 \\
\hline & 3 & $\mathrm{~V} 1-1 \mathrm{c}$ & 0 & 25.5 & 2.97 & off & 0.048 & 0.52 & 200.1 \\
\hline & 4 & V1 - 2 & 1 & 26.7 & 2.96 & off & 0.048 & 0.52 & 136.4 \\
\hline & 5 & V1 - 3 & 2 & 28.1 & 2.97 & off & 0.062 & 0.52 & 278.1 \\
\hline & 6 & V1 - 4 & 3 & 30.6 & 2.98 & off & 0.062 & 0.52 & 290.4 \\
\hline & 7 & V1 - 5 & 4 & 32.8 & 2.98 & off & 0.048 & 0.49 & 259.6 \\
\hline & 8 & $\mathrm{~V} 1-6 \mathrm{a}$ & 5 & 33.0 & 2.97 & off & 0.034 & 0.48 & 264.5 \\
\hline & 9 & V1 - 6b & 5 & 33.0 & 2.97 & off & 0.048 & 0.48 & 271.7 \\
\hline & 10 & $V 1-6 c$ & 5 & 33.0 & 2.97 & off & 0.048 & 0.48 & 273.5 \\
\hline & 11 & V1 - 7 & 6 & 23.7 & 2.96 & off & $<0.02^{\mathrm{x}}$ & 0.48 & 226.0 \\
\hline & 12 & V1 - 8 & 7 & 21.1 & 2.98 & off & 0.034 & 0.48 & 197.2 \\
\hline & 13 & V1 - 9 & 8 & 15.3 & 2.98 & off & $<0.02^{\mathrm{x}}$ & 0.46 & 183.5 \\
\hline & 14 & V1 - 10 & 9 & 13.4 & 2.98 & off & $<0.02^{\mathrm{x}}$ & 0.48 & 168.1 \\
\hline & 15 & $\mathrm{~V} 1-11 \mathrm{a}$ & 10 & 16.9 & 2.99 & off & $<0.02^{\mathrm{x}}$ & 0.48 & 144.7 \\
\hline & 16 & $\mathrm{~V} 1-11 \mathrm{~b}$ & 10 & 16.9 & 2.99 & off & $<0.02^{\mathrm{x}}$ & 0.48 & 161.8 \\
\hline & 17 & $\mathrm{~V} 1-11 \mathrm{c}$ & 10 & 16.9 & 2.99 & off & $<0.02^{\mathrm{x}}$ & 0.48 & 154.0 \\
\hline \multirow{15}{*}{ 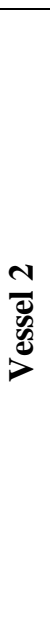 } & 18 & $\mathrm{~V} 2-1 \mathrm{a}$ & 0 & 25.1 & 3.01 & off & 0.13 & 0.71 & 249.9 \\
\hline & 19 & $\mathrm{~V} 2-1 \mathrm{~b}$ & 0 & 25.1 & 3.01 & off & 0.13 & 0.71 & 262.9 \\
\hline & 20 & $\mathrm{~V} 2-1 \mathrm{c}$ & 0 & 25.1 & 3.01 & off & 0.12 & 0.71 & 253.5 \\
\hline & 21 & $\mathrm{~V} 2-2$ & 1 & 26.8 & 2.99 & off & 0.15 & 0.75 & 282.8 \\
\hline & 22 & $V 2-3$ & 2 & 28.8 & 3.00 & off & 0.13 & 0.69 & 317.8 \\
\hline & 23 & $V 2-4$ & 3 & 30.2 & 2.99 & off & 0.15 & 0.68 & 361.9 \\
\hline & 24 & $V 2-5$ & 4 & 32.6 & 2.99 & off & 0.13 & 0.65 & 390.8 \\
\hline & 25 & $\mathrm{~V} 2-6 \mathrm{a}$ & 5 & 32.9 & 2.99 & off & 0.12 & 0.64 & 353.3 \\
\hline & 26 & $V 2-6 b$ & 5 & 32.9 & 2.99 & off & 0.12 & 0.65 & 361.9 \\
\hline & 27 & $V 2-6 c$ & 5 & 32.9 & 2.99 & off & 0.12 & 0.64 & 371.3 \\
\hline & 28 & $V 2-7$ & 6 & 23.5 & 2.97 & off & 0.12 & 0.62 & 321.8 \\
\hline & 29 & $V 2-8$ & 7 & 21.6 & 2.97 & off & 0.11 & 0.62 & 295.1 \\
\hline & 30 & $\mathrm{~V} 2-9$ & 8 & 18.6 & 2.97 & off & 0.091 & 0.64 & 273.7 \\
\hline & 31 & $\mathrm{~V} 2-10$ & 9 & 15.5 & 2.96 & off & 0.049 & 0.65 & 258.5 \\
\hline & 32 & $\mathrm{~V} 2-11 \mathrm{a}$ & 10 & 16.7 & 2.97 & off & 0.049 & 0.65 & 243.7 \\
\hline
\end{tabular}


Appendix C-3. Cycle 3 (10/25/2014) Data Continued

\begin{tabular}{|c|c|c|c|c|c|c|c|c|c|}
\hline & $\begin{array}{c}\text { Sample } \\
\text { No. }\end{array}$ & $\begin{array}{c}\text { Sample } \\
\text { Name }\end{array}$ & $\begin{array}{c}\text { Elapsed time } \\
(\mathrm{hr})\end{array}$ & $\begin{array}{c}\text { Temp. }^{+} \\
\left({ }^{\circ} \mathrm{C}\right)\end{array}$ & $\mathbf{p H}^{+}$ & $\begin{array}{c}\text { Light } \\
\text { (on/off) }\end{array}$ & $\begin{array}{c}\mathrm{Fe}^{\mathrm{II}^{*}} \\
(\mathrm{mg} / \mathrm{L})\end{array}$ & $\begin{array}{c}\text { Fe(total) } \\
(\mathrm{mg} / \mathrm{L})\end{array}$ & $\begin{array}{l}\mathrm{Se}^{\mathrm{IV**}} \\
(\mu \mathrm{g} / \mathrm{L})\end{array}$ \\
\hline \multirow[t]{2}{*}{$\mathbf{V 2}$} & 33 & $\mathrm{~V} 2-11 \mathrm{~b}$ & 10 & 16.7 & 2.97 & off & 0.035 & 0.65 & 240.9 \\
\hline & 34 & $\mathrm{~V} 2-11 \mathrm{c}$ & 10 & 16.7 & 2.97 & off & 0.035 & 0.65 & 245.9 \\
\hline \multirow{17}{*}{$\begin{array}{l}m \\
\bar{D} \\
\dot{0} \\
D\end{array}$} & 35 & V3 - 1a & 0 & 25.8 & 3.16 & off & 0.12 & 0.64 & 293.0 \\
\hline & 36 & $V 3-1 b$ & 0 & 25.8 & 3.16 & off & 0.12 & 0.65 & 306.4 \\
\hline & 37 & V3 - 1c & 0 & 25.8 & 3.16 & off & 0.12 & 0.64 & 288.0 \\
\hline & 38 & V3 - 2 & 1 & 27.7 & 3.17 & off & 0.13 & 0.64 & 292.8 \\
\hline & 39 & V3 - 3 & 2 & 30.2 & 3.18 & off & 0.12 & 0.62 & 312.3 \\
\hline & 40 & V3 - 4 & 3 & 32.7 & 3.16 & off & 0.12 & 0.58 & 308.9 \\
\hline & 41 & V3 - 5 & 4 & 35.8 & 3.17 & off & 0.077 & 0.56 & 520.4 \\
\hline & 42 & $v 3-6 a$ & 5 & 36.3 & 3.17 & off & 0.077 & 0.52 & 335.4 \\
\hline & 43 & $V 3-6 b$ & 5 & 36.3 & 3.17 & off & 0.077 & 0.52 & 339.6 \\
\hline & 44 & $V 3-6 c$ & 5 & 36.3 & 3.17 & off & 0.077 & 0.51 & 335.9 \\
\hline & 45 & V3 - 7 & 6 & 23.3 & 3.15 & off & 0.049 & 0.51 & 302.7 \\
\hline & 46 & V3 - 8 & 7 & 21.4 & 3.16 & off & 0.063 & 0.54 & 280.8 \\
\hline & 47 & V3 - 9 & 8 & 16.7 & 3.17 & off & 0.049 & 0.52 & 300.4 \\
\hline & 48 & V3 - 10 & 9 & 14.6 & 3.17 & off & $<0.02^{\mathrm{x}}$ & 0.54 & 271.4 \\
\hline & 49 & $\mathrm{~V} 3-11 \mathrm{a}$ & 10 & 16.8 & 3.18 & off & $<0.02^{\mathrm{x}}$ & 0.54 & 224.0 \\
\hline & 50 & $\mathrm{~V} 3-11 \mathrm{~b}$ & 10 & 16.8 & 3.18 & off & $<0.02^{\mathrm{x}}$ & 0.55 & 223.1 \\
\hline & 51 & $\mathrm{~V} 3-11 \mathrm{c}$ & 10 & 16.8 & 3.18 & off & $<0.02^{\mathrm{x}}$ & 0.52 & 1419 \\
\hline \multirow{13}{*}{ 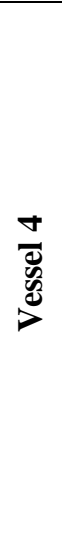 } & 52 & V4 - 1a & 0 & 25.3 & 2.94 & off & 0.091 & 0.62 & 175.8 \\
\hline & 53 & $\mathrm{~V} 4-1 \mathrm{~b}$ & 0 & 25.3 & 2.94 & off & 0.077 & 0.65 & 171.5 \\
\hline & 54 & $\mathrm{~V} 4-1 \mathrm{c}$ & 0 & 25.3 & 2.94 & off & 0.091 & 0.62 & 177.4 \\
\hline & 55 & V4 - 2 & 1 & 27.1 & 2.93 & off & 0.091 & 0.64 & 182.0 \\
\hline & 56 & V4 - 3 & 2 & 29.7 & 2.94 & off & 0.091 & 0.59 & 198.9 \\
\hline & 57 & V4 - 4 & 3 & 32.0 & 2.93 & off & 0.11 & 0.62 & 269.7 \\
\hline & 58 & V4 - 5 & 4 & 34.9 & 2.92 & off & 0.077 & 0.56 & 291.5 \\
\hline & 59 & V4 - 6a & 5 & 35.4 & 2.92 & off & 0.077 & 0.55 & 259.1 \\
\hline & 60 & $\mathrm{~V} 4-6 \mathrm{~b}$ & 5 & 35.4 & 2.92 & off & 0.091 & 0.59 & 262.0 \\
\hline & 61 & $\mathrm{~V} 4-6 \mathrm{c}$ & 5 & 35.4 & 2.92 & off & 0.063 & 0.56 & 266.7 \\
\hline & 62 & V4 - 7 & 6 & 23.7 & 2.95 & off & 0.049 & 0.54 & 246.6 \\
\hline & 63 & V4 - 8 & 7 & 21.8 & 2.95 & off & 0.063 & 0.56 & 213.7 \\
\hline & 64 & V4 - 9 & 8 & 19.4 & 2.96 & off & 0.049 & 0.56 & 246.3 \\
\hline
\end{tabular}


Appendix C-3. Cycle 3 (10/25/2014) Data Continued

\begin{tabular}{|c|c|c|c|c|c|c|c|c|c|}
\hline & $\begin{array}{c}\text { Sample } \\
\text { No. }\end{array}$ & $\begin{array}{c}\text { Sample } \\
\text { Name }\end{array}$ & $\begin{array}{c}\text { Elapsed time } \\
(\mathrm{hr})\end{array}$ & $\begin{array}{c}\text { Temp. }^{+} \\
\left({ }^{\circ} \mathrm{C}\right)\end{array}$ & $\mathbf{p H}^{+}$ & $\begin{array}{c}\text { Light } \\
\text { (on/off) }\end{array}$ & $\begin{array}{c}\mathrm{Fe}^{I I^{*}} \\
(\mathrm{mg} / \mathrm{L})\end{array}$ & $\begin{array}{c}\mathrm{Fe}(\text { total })^{*} \\
(\mathrm{mg} / \mathrm{L})\end{array}$ & $\begin{array}{l}\mathrm{Se}^{\mathrm{IV**}} \\
(\mu \mathrm{g} / \mathrm{L})\end{array}$ \\
\hline \multirow{4}{*}{ 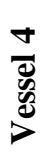 } & 65 & V4 - 10 & 9 & 18.6 & 2.96 & $\overline{\text { off }}$ & $<0.02^{\mathrm{x}}$ & 0.55 & 255.0 \\
\hline & 66 & $\mathrm{~V} 4-11 \mathrm{a}$ & 10 & 17.6 & 2.97 & off & $<0.02^{\mathrm{x}}$ & 0.58 & 221.4 \\
\hline & 67 & $\mathrm{~V} 4-11 \mathrm{~b}$ & 10 & 16.6 & 2.97 & off & $<0.02^{\mathrm{x}}$ & 0.55 & 218.7 \\
\hline & 68 & $\mathrm{~V} 4-11 \mathrm{c}$ & 10 & 15.6 & 2.97 & off & $<0.02^{\mathrm{x}}$ & 0.56 & 224.1 \\
\hline
\end{tabular}

${ }^{+}$Measured using DrDAQ PicoLog Recorder

Samples analyzed using HACH DR2800 Spectrophotometer

Samples analyzed using HG-ICP-OES (MDL $5 \mu \mathrm{g} / \mathrm{L} \mathrm{Se}{ }^{\mathrm{IV}}$ )

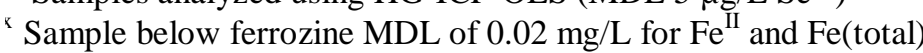

--- Sample not analyzed

Sample names including a,b,c are triplicate samples 
Appendix C-4. Cycle 4 (12/9/2014) Data

\begin{tabular}{|c|c|c|c|c|c|c|c|c|c|c|}
\hline & $\begin{array}{c}\text { Sample } \\
\text { No. }\end{array}$ & $\begin{array}{c}\text { Sample } \\
\text { Name }\end{array}$ & $\begin{array}{l}\text { Elapsed time } \\
(\mathrm{hr})\end{array}$ & $\begin{array}{c}\text { Temp. }^{+} \\
\left({ }^{\circ} \mathrm{C}\right)\end{array}$ & $\mathbf{p H}^{+}$ & $\begin{array}{c}\text { Light } \\
\text { (on/off) }\end{array}$ & $\begin{array}{c}\text { Light Intensity } \\
\text { (Lux) }\end{array}$ & $\begin{array}{c}\mathrm{Fe}^{\mathrm{II}^{*}} \\
(\mathrm{mg} / \mathrm{L})\end{array}$ & $\begin{array}{c}\text { Fe(total) } \\
(\mathrm{mg} / \mathrm{L})\end{array}$ & $\begin{array}{l}\mathrm{Se}^{\mathrm{I} \mathrm{V}^{* * *}} \\
(\mu \mathrm{g} / \mathrm{L})\end{array}$ \\
\hline \multirow{32}{*}{$\begin{array}{l}\overrightarrow{1} \\
\bar{D} \\
\text { \& } \\
2\end{array}$} & 1 & $\mathrm{~V} 1-1 \mathrm{a}$ & 0 & 22.2 & 2.75 & on & 3616.7 & 0.34 & 1.0 & -- \\
\hline & 2 & $\mathrm{~V} 1-1 \mathrm{~b}$ & 0 & 22.2 & 2.75 & on & 3616.7 & 0.35 & 1.1 & --- \\
\hline & 3 & $\mathrm{~V} 1-1 \mathrm{c}$ & 0 & 22.2 & 2.75 & on & 3616.7 & 0.35 & 1.0 & --- \\
\hline & 4 & $\mathrm{~V} 1-2 \mathrm{a}$ & 0.98 & 25.1 & 2.77 & on & 3788.9 & 0.34 & 1.0 & --- \\
\hline & 5 & $\mathrm{~V} 1-2 \mathrm{~b}$ & 0.98 & 25.1 & 2.77 & on & 3788.9 & 0.35 & 1.0 & --- \\
\hline & 6 & $\mathrm{~V} 1-2 \mathrm{c}$ & 0.98 & 25.1 & 2.77 & on & 3788.9 & 0.34 & 1.0 & --- \\
\hline & 7 & $\mathrm{~V} 1-3 \mathrm{a}$ & 1.77 & 30.1 & 2.72 & on & 3444.5 & 0.35 & 1.1 & --- \\
\hline & 8 & $V 1-3 b$ & 1.77 & 30.1 & 2.72 & on & 3444.5 & 0.35 & 1.1 & --- \\
\hline & 9 & $\mathrm{~V} 1-3 \mathrm{c}$ & 1.77 & 30.1 & 2.72 & on & 3444.5 & 0.34 & 1.1 & --- \\
\hline & 10 & $\mathrm{~V} 1-4 \mathrm{a}$ & 2.48 & 35.0 & 2.70 & on & 3616.7 & 0.35 & 1.1 & --- \\
\hline & 11 & $V 1-4 b$ & 2.48 & 35.0 & 2.70 & on & 3616.7 & 0.35 & 1.1 & --- \\
\hline & 12 & $\mathrm{~V} 1-4 \mathrm{c}$ & 2.48 & 35.0 & 2.70 & on & 3616.7 & 0.35 & 1.1 & --- \\
\hline & 13 & $\mathrm{~V} 1-5 \mathrm{a}$ & 3.61 & 29.8 & 2.69 & on & 3702.8 & 0.34 & 1.0 & --- \\
\hline & 14 & $\mathrm{~V} 1-5 b$ & 3.61 & 29.8 & 2.69 & on & 3702.8 & 0.35 & 0.97 & --- \\
\hline & 15 & $\mathrm{~V} 1-5 \mathrm{c}$ & 3.61 & 29.8 & 2.69 & on & 3702.8 & 0.34 & 1.0 & --- \\
\hline & 16 & $\mathrm{~V} 1-6 \mathrm{a}$ & 3.77 & 25.5 & 2.69 & on & 3358.4 & 0.33 & 1.0 & --- \\
\hline & 17 & $V 1-6 b$ & 3.77 & 25.5 & 2.69 & on & 3358.4 & 0.31 & 1.0 & --- \\
\hline & 18 & $V 1-6 c$ & 3.77 & 25.5 & 2.69 & on & 3358.4 & 0.33 & 1.0 & --- \\
\hline & 19 & $\mathrm{~V} 1-7 \mathrm{a}$ & 5.80 & 20.4 & 2.73 & on & 3702.8 & 0.33 & 1.1 & --- \\
\hline & 20 & $V 1-7 b$ & 5.80 & 20.4 & 2.73 & on & 3702.8 & 0.34 & 1.0 & --- \\
\hline & 21 & $\mathrm{~V} 1-7 \mathrm{c}$ & 5.80 & 20.4 & 2.73 & on & 3702.8 & 0.31 & 1.1 & --- \\
\hline & 22 & $\mathrm{~V} 1-8 \mathrm{a}$ & 6.02 & 14.9 & 2.71 & on & 3702.8 & 0.31 & 1.1 & --- \\
\hline & 23 & $\mathrm{~V} 1-8 \mathrm{~b}$ & 6.02 & 14.9 & 2.71 & on & 3702.8 & 0.35 & 1.0 & --- \\
\hline & 24 & $\mathrm{~V} 1-8 \mathrm{c}$ & 6.02 & 14.9 & 2.71 & on & 3702.8 & 0.33 & 1.0 & --- \\
\hline & 25 & $\mathrm{~V} 1-9 \mathrm{a}$ & 6.33 & 9.8 & 2.73 & on & 3530.6 & 0.30 & 1.0 & --- \\
\hline & 26 & $V 1-9 b$ & 6.33 & 9.8 & 2.73 & on & 3530.6 & 0.31 & 1.0 & --- \\
\hline & 27 & $\mathrm{~V} 1-9 \mathrm{c}$ & 6.33 & 9.8 & 2.73 & on & 3530.6 & 0.31 & 1.1 & --- \\
\hline & 28 & V1 - 10a & 6.83 & 5.5 & 2.74 & on & 3616.7 & 0.31 & 1.0 & --- \\
\hline & 29 & V1 - 10b & 6.83 & 5.5 & 2.74 & on & 3616.7 & 0.31 & 1.0 & --- \\
\hline & 30 & $\mathrm{~V} 1-10 \mathrm{c}$ & 6.83 & 5.5 & 2.74 & on & 3616.7 & 0.30 & 1.0 & --- \\
\hline & 31 & $\mathrm{~V} 1-11 \mathrm{a}$ & 7.59 & 11.1 & 2.69 & on & 3702.8 & 0.27 & 1.0 & --- \\
\hline & 32 & $\mathrm{~V} 1-11 \mathrm{~b}$ & 7.59 & 11.1 & 2.69 & on & 3702.8 & 0.26 & 1.0 & --- \\
\hline
\end{tabular}


Appendix C-4. Cycle 4 (12/9/2014) Data Continued

\begin{tabular}{|c|c|c|c|c|c|c|c|c|c|c|}
\hline & $\begin{array}{c}\text { Sample } \\
\text { No. }\end{array}$ & $\begin{array}{c}\text { Sample } \\
\text { Name }\end{array}$ & $\begin{array}{c}\text { Elapsed time } \\
(\mathrm{hr})\end{array}$ & $\begin{array}{c}\text { Temp. }^{+} \\
\left({ }^{\circ} \mathrm{C}\right)\end{array}$ & $\mathbf{p H}^{+}$ & $\begin{array}{c}\text { Light } \\
\text { (on/off) }\end{array}$ & $\begin{array}{c}\text { Light Intensity }^{++} \\
\text {(Lux) }\end{array}$ & $\begin{array}{c}\mathrm{Fe}^{\mathrm{II}^{*}} \\
(\mathrm{mg} / \mathrm{L})\end{array}$ & $\begin{array}{c}\mathrm{Fe}(\text { total }) \\
(\mathrm{mg} / \mathrm{L})\end{array}$ & $\begin{array}{l}\mathrm{Se}^{\mathrm{I} / * \cdots} \\
(\mu \mathrm{g} / \mathrm{L})\end{array}$ \\
\hline \multirow{16}{*}{ 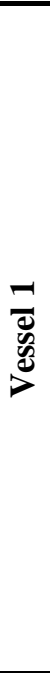 } & 33 & $\mathrm{~V} 1-11 \mathrm{c}$ & 7.59 & 11.1 & 2.69 & on & 3702.8 & 0.27 & 1.0 & --- \\
\hline & 34 & $\mathrm{~V} 1-12 \mathrm{a}$ & 7.74 & 15.6 & 2.73 & on & 3530.6 & 0.27 & 1.0 & --- \\
\hline & 35 & $\mathrm{~V} 1-12 b$ & 7.74 & 15.6 & 2.73 & on & 3530.6 & 0.23 & 1.0 & --- \\
\hline & 36 & $\mathrm{~V} 1-12 \mathrm{c}$ & 7.74 & 15.6 & 2.73 & on & 3530.6 & 0.24 & 1.1 & --- \\
\hline & 37 & $\mathrm{~V} 1-13 \mathrm{a}$ & 8.22 & 20.0 & 2.71 & on & 3444.5 & 0.28 & 1.0 & --- \\
\hline & 38 & $V 1-13 b$ & 8.22 & 20.0 & 2.71 & on & 3444.5 & 0.27 & 1.0 & --- \\
\hline & 39 & $\mathrm{~V} 1-13 \mathrm{c}$ & 8.22 & 20.0 & 2.71 & on & 3444.5 & 0.30 & 1.0 & --- \\
\hline & 40 & $\mathrm{~V} 1-14 \mathrm{a}$ & 8.88 & 25.4 & 2.67 & on & 3444.5 & 0.28 & 1.1 & --- \\
\hline & 41 & $\mathrm{~V} 1-14 \mathrm{~b}$ & 8.88 & 25.4 & 2.67 & on & 3444.5 & 0.28 & 1.1 & --- \\
\hline & 42 & $\mathrm{~V} 1-14 \mathrm{c}$ & 8.88 & 25.4 & 2.67 & on & 3444.5 & 0.28 & 1.0 & --- \\
\hline & 43 & V1 - 15a & 9.41 & 30.2 & 2.70 & on & 3444.5 & 0.33 & 1.1 & --- \\
\hline & 44 & $\mathrm{~V} 1-15 b$ & 9.41 & 30.2 & 2.70 & on & 3444.5 & 0.30 & 1.0 & --- \\
\hline & 45 & $\mathrm{~V} 1-15 \mathrm{c}$ & 9.41 & 30.2 & 2.70 & on & 3444.5 & 0.31 & 1.1 & --- \\
\hline & 46 & V1 - 16a & 9.99 & 36.5 & 2.67 & on & 3358.4 & 0.30 & 1.0 & --- \\
\hline & 47 & $\mathrm{~V} 1-16 \mathrm{~b}$ & 9.99 & 36.5 & 2.67 & on & 3358.4 & 0.30 & 1.1 & --- \\
\hline & 48 & $\mathrm{~V} 1-16 \mathrm{c}$ & 9.99 & 36.5 & 2.67 & on & 3358.4 & 0.31 & 1.1 & --- \\
\hline \multirow{16}{*}{ 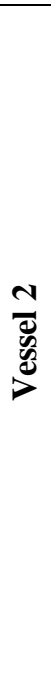 } & 49 & $\mathrm{~V} 2-1 \mathrm{a}$ & 0 & 22.3 & 2.83 & on & 3616.7 & 0.33 & 0.94 & --- \\
\hline & 50 & $\mathrm{~V} 2-1 \mathrm{a}$ & 0 & 22.3 & 2.83 & on & 3616.7 & 0.33 & 0.95 & --- \\
\hline & 51 & $\mathrm{~V} 2-1 \mathrm{a}$ & 0 & 22.3 & 2.83 & on & 3616.7 & 0.34 & 0.95 & --- \\
\hline & 52 & $\mathrm{~V} 2-2 \mathrm{a}$ & 0.75 & 25.0 & 2.84 & on & 3788.9 & 0.31 & 0.94 & --- \\
\hline & 53 & $\mathrm{~V} 2-2 \mathrm{~b}$ & 0.75 & 25.0 & 2.84 & on & 3788.9 & 0.33 & 0.93 & --- \\
\hline & 54 & $\mathrm{~V} 2-2 \mathrm{c}$ & 0.75 & 25.0 & 2.84 & on & 3788.9 & 0.33 & 0.93 & --- \\
\hline & 55 & $\mathrm{~V} 2-3 \mathrm{a}$ & 1.76 & 30.0 & 2.85 & on & 3444.5 & 0.31 & 0.97 & --- \\
\hline & 56 & $\mathrm{~V} 2-3 \mathrm{~b}$ & 1.76 & 30.0 & 2.85 & on & 3444.5 & 0.31 & 1.0 & --- \\
\hline & 57 & $V 2-3 c$ & 1.76 & 30.0 & 2.85 & on & 3444.5 & 0.33 & 0.98 & --- \\
\hline & 58 & $V 2-4 a$ & 3.06 & 35.0 & 2.82 & on & 3616.7 & 0.30 & 1.0 & --- \\
\hline & 59 & $V 2-4 b$ & 3.06 & 35.0 & 2.82 & on & 3616.7 & 0.31 & 1.0 & --- \\
\hline & 60 & $V 2-4 c$ & 3.06 & 35.0 & 2.82 & on & 3616.7 & 0.33 & 0.98 & --- \\
\hline & 61 & $\mathrm{~V} 2-5 a$ & 3.95 & 30.0 & 2.84 & on & 3702.8 & 0.31 & 0.94 & --- \\
\hline & 62 & $\mathrm{~V} 2-5 b$ & 3.95 & 30.0 & 2.84 & on & 3702.8 & 0.31 & 0.94 & --- \\
\hline & 63 & $V 2-5 c$ & 3.95 & 30.0 & 2.84 & on & 3702.8 & 0.33 & 0.93 & --- \\
\hline & 64 & $v 2-6 a$ & 4.17 & 25.5 & 2.83 & on & 3358.4 & 0.31 & 0.94 & --- \\
\hline
\end{tabular}


Appendix C-4. Cycle 4 (12/9/2014) Data Continued

\begin{tabular}{|c|c|c|c|c|c|c|c|c|c|c|}
\hline & $\begin{array}{c}\text { Sample } \\
\text { No. }\end{array}$ & $\begin{array}{c}\text { Sample } \\
\text { Name }\end{array}$ & $\begin{array}{c}\text { Elapsed time } \\
(\mathrm{hr})\end{array}$ & $\begin{array}{c}\text { Temp. }^{+} \\
\left({ }^{\circ} \mathrm{C}\right)\end{array}$ & $\mathbf{p H}^{+}$ & $\begin{array}{c}\text { Light } \\
\text { (on/off) }\end{array}$ & $\begin{array}{c}\text { Light Intensity }^{++} \\
\text {(Lux) }\end{array}$ & $\begin{array}{c}\mathrm{Fe}^{\mathrm{II}^{*}} \\
(\mathrm{mg} / \mathrm{L})\end{array}$ & $\begin{array}{c}\mathrm{Fe}(\text { total }) \\
(\mathrm{mg} / \mathrm{L})\end{array}$ & $\begin{array}{l}\mathrm{Se}^{\mathrm{I} / * \cdots} \\
(\mu \mathrm{g} / \mathrm{L})\end{array}$ \\
\hline \multirow{32}{*}{ 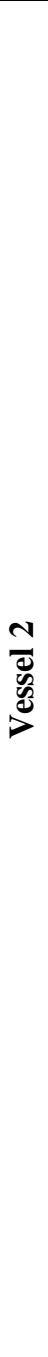 } & 65 & $\mathrm{~V} 2-6 \mathrm{~b}$ & 4.17 & 25.5 & 2.83 & on & 3358.4 & 0.31 & 0.95 & -- \\
\hline & 66 & $V 2-6 c$ & 4.17 & 25.5 & 2.83 & on & 3358.4 & 0.30 & 0.94 & --- \\
\hline & 67 & $\mathrm{~V} 2-7 \mathrm{a}$ & 5.80 & 20.3 & 2.81 & on & 3702.8 & 0.34 & 0.95 & --- \\
\hline & 68 & $V 2-7 b$ & 5.80 & 20.3 & 2.81 & on & 3702.8 & 0.33 & 0.95 & --- \\
\hline & 69 & $\mathrm{~V} 2-7 \mathrm{c}$ & 5.80 & 20.3 & 2.81 & on & 3702.8 & 0.34 & 0.93 & --- \\
\hline & 70 & $\mathrm{~V} 2-8 \mathrm{a}$ & 6.04 & 15.2 & 2.77 & on & 3702.8 & 0.33 & 0.91 & --- \\
\hline & 71 & $V 2-8 b$ & 6.04 & 15.2 & 2.77 & on & 3702.8 & 0.31 & 0.93 & --- \\
\hline & 72 & $\mathrm{~V} 2-8 \mathrm{c}$ & 6.04 & 15.2 & 2.77 & on & 3702.8 & 0.33 & 0.93 & --- \\
\hline & 73 & $\mathrm{~V} 2-9 \mathrm{a}$ & 6.34 & 10.4 & 2.78 & on & 3530.6 & 0.33 & 0.88 & --- \\
\hline & 74 & $V 2-9 b$ & 6.34 & 10.4 & 2.78 & on & 3530.6 & 0.30 & 0.84 & --- \\
\hline & 75 & $\mathrm{~V} 2-9 \mathrm{c}$ & 6.34 & 10.4 & 2.78 & on & 3530.6 & 0.30 & 0.87 & --- \\
\hline & 76 & $\mathrm{~V} 2-10 \mathrm{a}$ & 7.11 & 5.8 & 2.81 & on & 3616.7 & 0.30 & 0.93 & --- \\
\hline & 77 & $\mathrm{~V} 2-10 \mathrm{~b}$ & 7.11 & 5.8 & 2.81 & on & 3616.7 & 0.28 & 0.91 & --- \\
\hline & 78 & $\mathrm{~V} 2-10 \mathrm{c}$ & 7.11 & 5.8 & 2.81 & on & 3616.7 & 0.30 & 0.97 & --- \\
\hline & 79 & $\mathrm{~V} 2-11 \mathrm{a}$ & 7.60 & 11.6 & 2.81 & on & 3702.8 & 0.30 & 0.94 & --- \\
\hline & 80 & $\mathrm{~V} 2-11 \mathrm{~b}$ & 7.60 & 11.6 & 2.81 & on & 3702.8 & 0.27 & 0.93 & --- \\
\hline & 81 & $\mathrm{~V} 2-11 \mathrm{c}$ & 7.60 & 11.6 & 2.81 & on & 3702.8 & 0.27 & 0.93 & --- \\
\hline & 82 & $\mathrm{~V} 2-12 \mathrm{a}$ & 7.74 & 16.0 & 2.80 & on & 3530.6 & 0.26 & 0.94 & --- \\
\hline & 83 & $V 2-12 b$ & 7.74 & 16.0 & 2.80 & on & 3530.6 & 0.27 & 0.91 & --- \\
\hline & 84 & $\mathrm{~V} 2-12 \mathrm{c}$ & 7.74 & 16.0 & 2.80 & on & 3530.6 & 0.28 & 0.91 & --- \\
\hline & 85 & $\mathrm{~V} 2-13 \mathrm{a}$ & 8.13 & 20.4 & 2.79 & on & 3444.5 & 0.28 & 0.95 & --- \\
\hline & 86 & $V 2-13 b$ & 8.13 & 20.4 & 2.79 & on & 3444.5 & 0.27 & 0.93 & --- \\
\hline & 87 & $\mathrm{~V} 2-13 \mathrm{c}$ & 8.13 & 20.4 & 2.79 & on & 3444.5 & 0.27 & 0.91 & --- \\
\hline & 88 & $\mathrm{~V} 2-14 \mathrm{a}$ & 8.88 & 25.2 & 2.79 & on & 3444.5 & 0.30 & 0.95 & --- \\
\hline & 89 & $\mathrm{~V} 2-14 \mathrm{~b}$ & 8.88 & 25.2 & 2.79 & on & 3444.5 & 0.28 & 0.95 & --- \\
\hline & 90 & $\mathrm{~V} 2-14 \mathrm{c}$ & 8.88 & 25.2 & 2.79 & on & 3444.5 & 0.28 & 0.95 & --- \\
\hline & 91 & $\mathrm{~V} 2-15 \mathrm{a}$ & 9.51 & 30.0 & 2.81 & on & 3444.5 & 0.30 & 0.94 & --- \\
\hline & 92 & $\mathrm{~V} 2-15 b$ & 9.51 & 30.0 & 2.81 & on & 3444.5 & 0.28 & 0.94 & --- \\
\hline & 93 & $\mathrm{~V} 2-15 \mathrm{c}$ & 9.51 & 30.0 & 2.81 & on & 3444.5 & 0.31 & 0.94 & --- \\
\hline & 94 & $\mathrm{~V} 2-16 \mathrm{a}$ & 9.99 & 35.4 & 2.82 & on & 3358.4 & 0.28 & 0.97 & --- \\
\hline & 95 & $V 2-16 b$ & 9.99 & 35.4 & 2.82 & on & 3358.4 & 0.26 & 0.95 & --- \\
\hline & 96 & $\mathrm{~V} 2-16 \mathrm{c}$ & 9.99 & 35.4 & 2.82 & on & 3358.4 & 0.30 & 0.88 & --- \\
\hline
\end{tabular}


Appendix C-4. Cycle 4 (12/9/2014) Data Continued

\begin{tabular}{|c|c|c|c|c|c|c|c|c|c|c|}
\hline & $\begin{array}{c}\text { Sample } \\
\text { No. }\end{array}$ & $\begin{array}{c}\text { Sample } \\
\text { Name }\end{array}$ & $\begin{array}{l}\text { Elapsed time } \\
(\mathrm{hr})\end{array}$ & $\begin{array}{c}\text { Temp. }^{+} \\
\left({ }^{\circ} \mathrm{C}\right)\end{array}$ & $\mathbf{p H}^{+}$ & $\begin{array}{c}\text { Light } \\
\text { (on/off) }\end{array}$ & $\begin{array}{c}\text { Light Intensity }^{++} \\
\text {(Lux) }\end{array}$ & $\begin{array}{c}\mathrm{Fe}^{\mathrm{II*}} \\
(\mathrm{mg} / \mathrm{L})\end{array}$ & $\begin{array}{c}\mathrm{Fe}(\text { total })^{*} \\
(\mathrm{mg} / \mathrm{L})\end{array}$ & $\begin{array}{l}\mathrm{Se}^{\mathrm{IN*36}} \\
(\mu \mathrm{g} / \mathrm{L})\end{array}$ \\
\hline \multirow{24}{*}{ 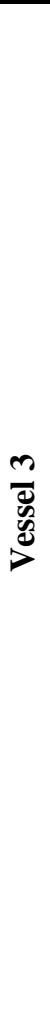 } & 97 & $\mathrm{~V} 3-1 \mathrm{a}$ & 0 & 22.3 & 3.17 & on & 3616.7 & 0.31 & 1.0 & 15.60 \\
\hline & 98 & $V 3-1 b$ & 0 & 22.3 & 3.17 & on & 3616.7 & 0.33 & 1.0 & 14.69 \\
\hline & 99 & $V 3-1 c$ & 0 & 22.3 & 3.17 & on & 3616.7 & 0.33 & 1.0 & 12.38 \\
\hline & 100 & V3 - 2 & 0.45 & 25.6 & 3.16 & on & 3788.9 & 0.34 & 1.0 & 11.83 \\
\hline & 101 & V3 - 3 & 1.50 & 31.3 & 3.17 & on & 3444.5 & 0.28 & 1.1 & 11.10 \\
\hline & 102 & V3 - 4 & 2.43 & 35.5 & 3.15 & on & 3616.7 & 0.30 & 1.0 & 81.47 \\
\hline & 103 & $\mathrm{~V} 3-5 \mathrm{a}$ & 3.25 & 30.0 & 2.98 & on & 3702.8 & 0.33 & 1.0 & 10.33 \\
\hline & 104 & $V 3-5 b$ & 3.25 & 30.0 & 2.98 & on & 3702.8 & 0.30 & 1.0 & 10.60 \\
\hline & 105 & $V 3-5 c$ & 3.25 & 30.0 & 2.98 & on & 3702.8 & 0.30 & 1.0 & 14.66 \\
\hline & 106 & V3 - 6 & 3.28 & 25.1 & 3.19 & on & 3358.4 & 0.31 & 1.0 & 11.31 \\
\hline & 107 & V3 - 7 & 5.65 & 19.8 & 3.21 & on & 3702.8 & 0.31 & 1.0 & 12.88 \\
\hline & 108 & V3 - 8 & 5.90 & 14.9 & 3.24 & on & 3702.8 & 0.30 & 1.0 & 14.19 \\
\hline & 109 & V3 - 9 & 6.14 & 9.8 & 3.29 & on & 3530.6 & 0.30 & 1.0 & 13.51 \\
\hline & 110 & V3 - 10a & 6.81 & 2.2 & 3.35 & on & 3616.7 & 0.28 & 0.98 & 11.81 \\
\hline & 111 & $\mathrm{~V} 3-10 \mathrm{~b}$ & 6.81 & 2.2 & 3.35 & on & 3616.7 & 0.28 & 0.98 & 12.81 \\
\hline & 112 & $\mathrm{~V} 3-10 \mathrm{c}$ & 6.81 & 2.2 & 3.35 & on & 3616.7 & 0.27 & 0.98 & 12.41 \\
\hline & 113 & V3 - 11 & 7.58 & 11.7 & 3.22 & on & 3702.8 & 0.27 & 1.0 & 11.67 \\
\hline & 114 & V3 - 12 & 7.67 & 15.7 & 3.21 & on & 3530.6 & 0.28 & 1.0 & 13.99 \\
\hline & 115 & V3 - 13 & 8.37 & 21.0 & 3.18 & on & 3444.5 & 0.27 & 1.0 & 13.46 \\
\hline & 116 & V3 - 14 & 8.54 & 25.0 & 3.20 & on & 3444.5 & 0.27 & 1.1 & 11.46 \\
\hline & 117 & V3 - 15 & 9.36 & 31.5 & 3.20 & on & 3444.5 & 0.28 & 1.0 & 9.000 \\
\hline & 118 & V3 - 16a & 9.76 & 35.0 & 3.20 & on & 3358.4 & 0.31 & 1.0 & 9.630 \\
\hline & 119 & $V 3-16 b$ & 9.76 & 35.0 & 3.20 & on & 3358.4 & 0.30 & 1.1 & 8.920 \\
\hline & 120 & $\mathrm{~V} 3-16 \mathrm{c}$ & 9.76 & 35.0 & 3.20 & on & 3358.4 & 0.30 & 1.0 & $<5^{\mathrm{xx}}$ \\
\hline \multirow{8}{*}{ 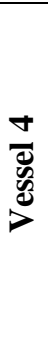 } & 121 & V4 - 1a & 0 & 22.0 & 2.74 & on & 3616.7 & 0.38 & 1.0 & $<5^{\mathrm{xx}}$ \\
\hline & 122 & $\mathrm{~V} 4-1 \mathrm{~b}$ & 0 & 22.0 & 2.74 & on & 3616.7 & 0.38 & 1.0 & 38.18 \\
\hline & 123 & $\mathrm{~V} 4-1 \mathrm{c}$ & 0 & 22.0 & 2.74 & on & 3616.7 & 0.38 & 1.0 & 37.03 \\
\hline & 124 & V4 - 2 & 0.45 & 25.1 & 2.77 & on & 3788.9 & 0.37 & 0.98 & 40.25 \\
\hline & 125 & V4 - 3 & 1.51 & 30.2 & 2.98 & on & 3444.5 & 0.34 & 1.0 & 45.78 \\
\hline & 126 & V4 - 4 & 2.94 & 35.5 & 2.66 & on & 3616.7 & 0.38 & 1.0 & 71.37 \\
\hline & 127 & $\mathrm{~V} 4-5 \mathrm{a}$ & 3.66 & 29.8 & 2.66 & on & 3702.8 & 0.40 & 0.98 & 84.74 \\
\hline & 128 & $\mathrm{~V} 4-5 \mathrm{~b}$ & 3.66 & 29.8 & 2.66 & on & 3702.8 & 0.38 & 0.97 & 80.81 \\
\hline
\end{tabular}


Appendix C-4. Cycle 4 (12/9/2014) Data Continued

\begin{tabular}{|c|c|c|c|c|c|c|c|c|c|c|}
\hline & $\begin{array}{c}\text { Sample } \\
\text { No. }\end{array}$ & $\begin{array}{c}\text { Sample } \\
\text { Name }\end{array}$ & $\begin{array}{c}\text { Elapsed time } \\
(\mathrm{hr})\end{array}$ & $\begin{array}{c}\text { Temp. } \\
\left({ }^{\circ} \mathrm{C}\right)\end{array}$ & $\mathbf{p H}^{+}$ & $\begin{array}{c}\text { Light } \\
\text { (on/off) }\end{array}$ & $\begin{array}{c}\text { Light Intensity }^{++} \\
(\text {Lux })\end{array}$ & $\begin{array}{c}\mathrm{Fe}^{\mathrm{II*}} \\
(\mathrm{mg} / \mathrm{L})\end{array}$ & $\begin{array}{c}\mathrm{Fe}(\text { total })^{*} \\
(\mathrm{mg} / \mathrm{L})\end{array}$ & $\begin{array}{l}\mathrm{Se}^{\mathrm{IV**}} \\
(\mu \mathrm{g} / \mathrm{L})\end{array}$ \\
\hline \multirow{16}{*}{ 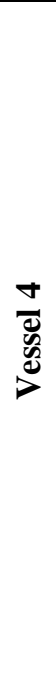 } & 129 & $\mathrm{~V} 4-5 \mathrm{c}$ & 3.66 & 29.8 & 2.66 & on & 3702.8 & 0.35 & 1.0 & 85.07 \\
\hline & 130 & V4 - 6 & 3.87 & 25.0 & 2.72 & on & 3358.4 & 0.34 & 0.97 & 82.37 \\
\hline & 131 & V4 - 7 & 5.80 & 20.1 & 2.72 & on & 3702.8 & 0.34 & 0.98 & 57.63 \\
\hline & 132 & V4 - 8 & 6.04 & 14.7 & 2.71 & on & 3702.8 & 0.31 & 0.95 & 49.26 \\
\hline & 133 & V4 - 9 & 6.34 & 9.8 & 2.75 & on & 3530.6 & 0.31 & 0.88 & 48.44 \\
\hline & 134 & V4 - 10a & 6.97 & 5.0 & 2.82 & on & 3616.7 & 0.28 & 0.93 & 34.87 \\
\hline & 135 & V4 - 10b & 6.97 & 5.0 & 2.82 & on & 3616.7 & 0.28 & 0.94 & 36.33 \\
\hline & 136 & $\mathrm{~V} 4-10 \mathrm{c}$ & 6.97 & 5.0 & 2.82 & on & 3616.7 & 0.26 & 0.90 & 38.29 \\
\hline & 137 & V4 - 11 & 7.62 & 11.4 & 2.80 & on & 3702.8 & 0.30 & 0.88 & 36.23 \\
\hline & 138 & V4 - 12 & 7.74 & 15.1 & 2.76 & on & 3530.6 & 0.28 & 1.0 & 37.25 \\
\hline & 139 & V4 - 13 & 8.25 & 20.0 & 2.72 & on & 3444.5 & 0.30 & 1.0 & 34.82 \\
\hline & 140 & V4 - 14 & 8.89 & 25.1 & 2.70 & on & 3444.5 & 0.31 & 0.98 & 38.00 \\
\hline & 141 & V4 - 15 & 9.51 & 30.3 & 2.69 & on & 3444.5 & 0.31 & 1.0 & 34.30 \\
\hline & 142 & V4 - $16 a$ & 9.88 & 35.0 & 2.70 & on & 3358.4 & 0.34 & 1.0 & 33.46 \\
\hline & 143 & $\mathrm{~V} 4-16 b$ & 9.88 & 35.0 & 2.70 & on & 3358.4 & 0.34 & 0.97 & 35.66 \\
\hline & 144 & $\mathrm{~V} 4-16 \mathrm{c}$ & 9.88 & 35.0 & 2.70 & on & 3358.4 & 0.33 & 1.0 & 34.92 \\
\hline
\end{tabular}

${ }^{+}$Measured using DrDAQ PicoLog Recorder

${ }^{++}$Measured using HOBO Pendant Light/Temperature Loggers

* Samples analyzed using HACH DR2800 Spectrophotometer (MDL $0.02 \mathrm{mg} / \mathrm{L}$ for Fe ${ }^{\mathrm{II}}$ and Fe(total))

Samples analyzed using HG-ICP-OES

${ }^{\mathrm{xx}}$ Sample below HG-ICP-OES MDL of $5 \mu \mathrm{g} / \mathrm{L}$ for $\mathrm{Se}^{\mathrm{IV}}$

--- Sample not analyzed

Sample names including a,b,c are triplicate samples 
Appendix C-5. Cycle 5 (1/29/2015) Data

\begin{tabular}{|c|c|c|c|c|c|c|c|c|}
\hline & $\begin{array}{c}\text { Sample } \\
\text { No. }\end{array}$ & $\begin{array}{c}\text { Sample } \\
\text { Name }\end{array}$ & $\begin{array}{l}\text { Elapsed time } \\
(\mathrm{hr})\end{array}$ & $\begin{array}{c}\text { Temp. }^{+} \\
\left({ }^{\circ} \mathrm{C}\right)\end{array}$ & $\mathbf{p H}^{+}$ & $\begin{array}{c}\text { Light } \\
\text { (on/off) }\end{array}$ & $\begin{array}{c}\text { Light Intensity }^{++} \\
\text {(Lux) }\end{array}$ & $\begin{array}{l}\mathrm{Se}^{\mathrm{IV**}} \\
(\mu \mathrm{g} / \mathrm{L})\end{array}$ \\
\hline \multirow{10}{*}{$\begin{array}{l}\bar{D} \\
\overline{8} \\
\dot{8} \\
>\end{array}$} & 1 & $\mathrm{~V} 1-1$ & 0 & 25.0 & 2.72 & on & 1431.6 & 284.1 \\
\hline & 2 & V1 - 2 & 0.25 & 30.0 & 2.72 & on & 1437.0 & 328.2 \\
\hline & 3 & $\mathrm{~V} 1-3 \mathrm{a}$ & 0.82 & 35.1 & 2.71 & on & 1334.8 & 333.3 \\
\hline & 4 & $\mathrm{~V} 1-3 \mathrm{~b}$ & 0.82 & 35.1 & 2.71 & on & 1334.8 & 306.0 \\
\hline & 5 & $\mathrm{~V} 1-3 \mathrm{c}$ & 0.82 & 35.1 & 2.71 & on & 1334.8 & 321.4 \\
\hline & 6 & V1 - 4 & 2.57 & 30.0 & 2.70 & on & 1237.9 & 309.4 \\
\hline & 7 & V1 - 5 & 3.02 & 24.4 & 2.70 & on & 1243.3 & 321.1 \\
\hline & 8 & V1 - 6 & 3.12 & 19.6 & 2.69 & on & 1173.3 & 297.7 \\
\hline & 9 & $\mathrm{~V} 1-7 \mathrm{a}$ & 3.32 & 14.9 & 2.68 & on & 1211.0 & 309.0 \\
\hline & 10 & $\mathrm{~V} 1-7 \mathrm{~b}$ & 3.32 & 14.9 & 2.68 & on & 1211.0 & 305.3 \\
\hline \multirow{10}{*}{ 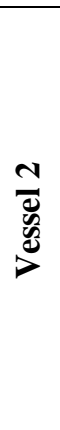 } & 11 & $\mathrm{~V} 2-1$ & 0 & 25.0 & 2.62 & on & 1431.6 & 333.5 \\
\hline & 12 & $\mathrm{~V} 2-2$ & 0.20 & 30.0 & 2.63 & on & 1437.0 & 339.6 \\
\hline & 13 & $\mathrm{~V} 2-3 \mathrm{a}$ & 0.80 & 35.0 & 2.63 & on & 1334.8 & 343.3 \\
\hline & 14 & $V 2-3 b$ & 0.80 & 35.0 & 2.63 & on & 1334.8 & 347.6 \\
\hline & 15 & $\mathrm{~V} 2-3 \mathrm{c}$ & 0.80 & 35.0 & 2.63 & on & 1334.8 & 351.8 \\
\hline & 16 & V2 - 4 & 1.73 & 30.0 & 2.64 & on & 1237.9 & 371.5 \\
\hline & 17 & $V 2-5$ & 2.57 & 24.8 & 2.63 & on & 1243.3 & 352.4 \\
\hline & 18 & V2 - 6 & 3.03 & 19.8 & 2.63 & on & 1173.3 & 334.8 \\
\hline & 19 & $\mathrm{~V} 2-7 \mathrm{a}$ & 3.23 & 13.7 & 2.61 & on & 1211.0 & 328.8 \\
\hline & 20 & $V 2-7 b$ & 3.23 & 13.7 & 2.61 & on & 1211.0 & 251.8 \\
\hline \multirow{10}{*}{ 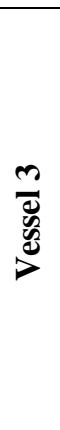 } & 21 & V3 - 1 & 0 & 25.0 & 3.14 & on & 1431.6 & 281.4 \\
\hline & 22 & V3 - 2 & 0.27 & 30.0 & 3.14 & on & 1437.0 & 308.1 \\
\hline & 23 & $\mathrm{~V} 3-3 \mathrm{a}$ & 0.50 & 35.0 & 3.16 & on & 1334.8 & 309.1 \\
\hline & 24 & $\mathrm{~V} 3-3 \mathrm{~b}$ & 0.50 & 35.0 & 3.16 & on & 1334.8 & 284.5 \\
\hline & 25 & $V 3-3 c$ & 0.50 & 35.0 & 3.16 & on & 1334.8 & 287.9 \\
\hline & 26 & V3 - 4 & 1.50 & 29.8 & 3.17 & on & 1237.9 & 222.4 \\
\hline & 27 & $V 3-5$ & 1.73 & 24.9 & 3.16 & on & 1243.3 & 266.6 \\
\hline & 28 & V3 - 6 & 2.10 & 19.2 & 3.18 & on & 1173.3 & 298.5 \\
\hline & 29 & $\mathrm{~V} 3-7 \mathrm{a}$ & 2.42 & 14.5 & 3.20 & on & 1211.0 & 291.0 \\
\hline & 30 & $V 3-7 b$ & 2.42 & 14.5 & 3.20 & on & 1211.0 & 297.2 \\
\hline \multirow[t]{2}{*}{ V4 } & 31 & $\mathrm{~V} 4-1$ & 0 & 25.2 & 2.62 & on & 1431.6 & 194.5 \\
\hline & 32 & V4 - 2 & 0.35 & 30.0 & 2.61 & on & 1437.0 & 234.9 \\
\hline
\end{tabular}


Appendix C-5. Cycle 5 (1/29/2015) Data Continued

\begin{tabular}{|c|c|c|c|c|c|c|c|c|}
\hline & $\begin{array}{c}\text { Sample } \\
\text { No. }\end{array}$ & $\begin{array}{c}\text { Sample } \\
\text { Name }\end{array}$ & $\begin{array}{l}\text { Elapsed time } \\
(\mathrm{hr})\end{array}$ & $\begin{array}{c}\text { Temp. }^{+} \\
\left({ }^{\circ} \mathrm{C}\right)\end{array}$ & $\mathbf{p H}^{+}$ & $\begin{array}{c}\text { Light } \\
\text { (on/off) }\end{array}$ & $\begin{array}{c}\text { Light Intensity }^{++} \\
\text {(Lux) }\end{array}$ & $\begin{array}{l}\mathrm{Se}^{\mathrm{IV**}} \\
(\mu \mathrm{g} / \mathrm{L})\end{array}$ \\
\hline \multirow{8}{*}{ 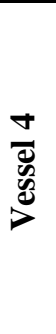 } & 33 & $\mathrm{~V} 4-3 \mathrm{a}$ & 0.70 & 35.2 & 2.60 & on & 1334.8 & 202.4 \\
\hline & 34 & $\mathrm{~V} 4-3 \mathrm{~b}$ & 0.70 & 35.2 & 2.60 & on & 1334.8 & 199.2 \\
\hline & 35 & $\mathrm{~V} 4-3 \mathrm{c}$ & 0.70 & 35.2 & 2.60 & on & 1334.8 & 212.2 \\
\hline & 36 & V4 - 4 & 1.62 & 29.9 & 2.59 & on & 1237.9 & 281.7 \\
\hline & 37 & V4 - 5 & 2.07 & 24.8 & 2.60 & on & 1243.3 & 233.8 \\
\hline & 38 & V4 - 6 & 2.43 & 19.7 & 2.63 & on & 1173.3 & --- \\
\hline & 39 & $\mathrm{~V} 4-7 \mathrm{a}$ & 2.92 & 18.1 & 2.63 & on & 1211.0 & 225.3 \\
\hline & 40 & $\mathrm{~V} 4-7 \mathrm{~b}$ & 2.92 & 18.1 & 2.63 & on & 1211.0 & 233.9 \\
\hline
\end{tabular}

${ }^{\digamma}$ Measured using DrDAQ PicoLog Recorder

${ }^{++}$Measured using HOBO Pendant Light/Temperature Loggers

** Samples analyzed using HG-ICP-OES

${ }^{x x}$ Sample below HG-ICP-OES MDL of $5 \mu \mathrm{g} / \mathrm{L}$ for $\mathrm{Se}^{\mathrm{IV}}$

-- Sample not analyzed

Sample names including a,b,c are double or triplicate samples 
Appendix C-6. Cycle 6 (2/28/2015) Data

\begin{tabular}{|c|c|c|c|c|c|c|c|c|c|}
\hline & $\begin{array}{c}\text { Sample } \\
\text { No. }\end{array}$ & $\begin{array}{c}\text { Sample } \\
\text { Name }\end{array}$ & $\begin{array}{c}\text { Elapsed time } \\
(\mathrm{hr})\end{array}$ & $\begin{array}{c}\text { Temp. }^{+} \\
\left({ }^{\circ} \mathrm{C}\right)\end{array}$ & $\mathbf{p H}^{+}$ & $\begin{array}{c}\text { Light } \\
\text { (on/off) }\end{array}$ & $\begin{array}{c}\mathrm{Fe}^{\mathrm{II} *} \\
(\mathrm{mg} / \mathrm{L})\end{array}$ & $\begin{array}{c}\mathrm{Fe}(\text { total })^{*} \\
(\mathrm{mg} / \mathrm{L})\end{array}$ & $\begin{array}{l}\mathrm{Se}^{\mathrm{I} \mathrm{V}^{* *}} \\
(\mu \mathrm{g} / \mathrm{L})\end{array}$ \\
\hline \multirow{24}{*}{$\begin{array}{l}\bar{D} \\
\overline{0} \\
\overline{2}\end{array}$} & 1 & $\mathrm{~V} 1-1 \mathrm{a}$ & 0 & 18.1 & 3.19 & off & $<0.02^{\mathrm{x}}$ & 0.35 & -- \\
\hline & 2 & $\mathrm{~V} 1-1 \mathrm{~b}$ & 0 & 18.1 & 3.19 & off & $<0.02^{\mathrm{x}}$ & 0.32 & --- \\
\hline & 3 & $\mathrm{~V} 1-1 \mathrm{c}$ & 0 & 18.1 & 3.19 & off & $<0.02^{\mathrm{x}}$ & 0.33 & --- \\
\hline & 4 & V1 - 2 & 1.08 & 25.0 & 3.20 & off & $<0.02^{\mathrm{x}}$ & 0.33 & --- \\
\hline & 5 & V1 - 3 & 1.20 & 30.9 & 3.19 & off & $<0.02^{\mathrm{x}}$ & 0.30 & --- \\
\hline & 6 & V1 - 4 & 1.78 & 36.2 & 3.16 & off & $<0.02^{\mathrm{x}}$ & 0.22 & --- \\
\hline & 7 & $\mathrm{~V} 1-5 \mathrm{a}$ & 2.11 & 28.6 & 3.15 & off & $<0.02^{\mathrm{x}}$ & 0.32 & --- \\
\hline & 8 & $\mathrm{~V} 1-5 \mathrm{~b}$ & 2.11 & 28.6 & 3.15 & off & $<0.02^{\mathrm{x}}$ & 0.32 & --- \\
\hline & 9 & $\mathrm{~V} 1-5 \mathrm{c}$ & 2.11 & 28.6 & 3.15 & off & $<0.02^{\mathrm{x}}$ & 0.36 & --- \\
\hline & 10 & V1 - 6 & 2.84 & 23.7 & 3.18 & off & $<0.02^{\mathrm{x}}$ & 0.30 & --- \\
\hline & 11 & V1 - 7 & 4.11 & 20.1 & 3.18 & off & $<0.02^{\mathrm{x}}$ & 0.30 & --- \\
\hline & 12 & V1 - 8 & 4.36 & 15.1 & 3.20 & off & $<0.02^{\mathrm{x}}$ & 0.22 & --- \\
\hline & 13 & V1 - 9 & 4.66 & 10.0 & 3.21 & off & $<0.02^{\mathrm{x}}$ & 0.25 & --- \\
\hline & 14 & $\mathrm{~V} 1-10 \mathrm{a}$ & 5.13 & 5.0 & 3.20 & off & $<0.02^{\mathrm{x}}$ & 0.22 & --- \\
\hline & 15 & $\mathrm{~V} 1-10 \mathrm{~b}$ & 5.13 & 5.0 & 3.20 & off & $<0.02^{\mathrm{x}}$ & 0.22 & --- \\
\hline & 16 & $\mathrm{~V} 1-10 \mathrm{c}$ & 5.13 & 5.0 & 3.20 & off & $<0.02^{\mathrm{x}}$ & 0.23 & --- \\
\hline & 17 & V1 - 11 & 5.68 & 10.0 & 3.21 & off & $<0.02^{\mathrm{x}}$ & 0.20 & --- \\
\hline & 18 & V1 - 12 & 6.10 & 15.3 & 3.18 & off & $<0.02^{\mathrm{x}}$ & 0.22 & --- \\
\hline & 19 & V1 - 13 & 6.33 & 20.2 & 3.17 & off & $<0.02^{\mathrm{x}}$ & 0.20 & --- \\
\hline & 20 & V1 - 14 & 6.60 & 25.1 & 3.17 & off & $<0.02^{\mathrm{x}}$ & 0.20 & --- \\
\hline & 21 & V1 - 15 & 6.83 & 30.1 & 3.16 & off & $<0.02^{\mathrm{x}}$ & 0.20 & --- \\
\hline & 22 & $\mathrm{~V} 1-16 \mathrm{a}$ & 7.04 & 35.2 & 3.15 & off & $<0.02^{\mathrm{x}}$ & 0.19 & --- \\
\hline & 23 & $\mathrm{~V} 1-16 b$ & 7.04 & 35.2 & 3.15 & off & $<0.02^{\mathrm{x}}$ & 0.20 & --- \\
\hline & 24 & $V 1-16 c$ & 7.04 & 35.2 & 3.15 & off & $<0.02^{\mathrm{x}}$ & 0.20 & --- \\
\hline \multirow{8}{*}{$\begin{array}{l}N \\
\bar{D} \\
\text { Dे } \\
D^{2}\end{array}$} & 25 & $\mathrm{~V} 2-1 \mathrm{a}$ & 0 & 18.2 & 3.60 & off & $<0.02^{\mathrm{x}}$ & 0.046 & --- \\
\hline & 26 & $\mathrm{~V} 2-1 \mathrm{~b}$ & 0 & 18.2 & 3.60 & off & $<0.02^{\mathrm{x}}$ & 0.060 & --- \\
\hline & 27 & $\mathrm{~V} 2-1 \mathrm{c}$ & 0 & 18.2 & 3.60 & off & $<0.02^{\mathrm{x}}$ & 0.060 & --- \\
\hline & 28 & $\mathrm{~V} 2-2$ & 1.20 & 25.0 & 3.59 & off & $<0.02^{\mathrm{x}}$ & 0.060 & --- \\
\hline & 29 & $V 2-3$ & 1.50 & 30.0 & 3.59 & off & $<0.02^{\mathrm{x}}$ & $<0.02^{\mathrm{x}}$ & --- \\
\hline & 30 & $V 2-4$ & 1.82 & 35.2 & 3.55 & off & $<0.02^{\mathrm{x}}$ & $<0.02^{\mathrm{x}}$ & --- \\
\hline & 31 & $\mathrm{~V} 2-5 \mathrm{a}$ & 2.25 & 26.5 & 3.54 & off & $<0.02^{\mathrm{x}}$ & $<0.02^{\mathrm{x}}$ & --- \\
\hline & 32 & $\mathrm{~V} 2-5 b$ & 2.25 & 26.5 & 3.54 & off & $<0.02^{\mathrm{x}}$ & 0.12 & --- \\
\hline
\end{tabular}


Appendix C-6. Cycle 6 (2/28/2015) Data Continued

\begin{tabular}{|c|c|c|c|c|c|c|c|c|c|}
\hline & $\begin{array}{c}\text { Sample } \\
\text { No. }\end{array}$ & $\begin{array}{c}\text { Sample } \\
\text { Name } \\
\end{array}$ & $\begin{array}{c}\text { Elapsed time } \\
(\mathrm{hr})\end{array}$ & $\begin{array}{c}\text { Temp. }^{+} \\
\left({ }^{\circ} \mathrm{C}\right)\end{array}$ & $\mathbf{p H}^{+}$ & $\begin{array}{c}\text { Light } \\
\text { (on/off) }\end{array}$ & $\begin{array}{c}\mathrm{Fe}^{\mathrm{II*}} \\
(\mathrm{mg} / \mathrm{L})\end{array}$ & $\begin{array}{c}\mathrm{Fe}(\text { total })^{*} \\
(\mathrm{mg} / \mathrm{L})\end{array}$ & $\begin{array}{l}\mathrm{Se}^{\mathrm{IV**}} \\
(\mu \mathrm{g} / \mathrm{L})\end{array}$ \\
\hline \multirow{16}{*}{ 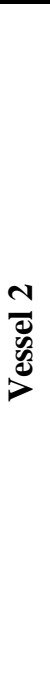 } & 33 & $V 2-5 c$ & 2.25 & 26.5 & 3.54 & $\overline{\text { off }}$ & $<0.02^{\mathrm{x}}$ & 0.15 & --- \\
\hline & 34 & $v 2-6$ & 2.85 & 22.9 & 3.55 & off & $<0.02^{\mathrm{x}}$ & 0.089 & --- \\
\hline & 35 & $\mathrm{~V} 2-7$ & 3.78 & 20.0 & 3.55 & off & $<0.02^{\mathrm{x}}$ & 1.3 & --- \\
\hline & 36 & V2 - 8 & 4.16 & 14.2 & 3.59 & off & $<0.02^{\mathrm{x}}$ & 0.046 & --- \\
\hline & 37 & $\mathrm{~V} 2-9$ & 4.46 & 10.0 & 3.59 & off & $<0.02^{\mathrm{x}}$ & 0.046 & --- \\
\hline & 38 & $\mathrm{~V} 2-10 \mathrm{a}$ & 4.86 & 4.8 & 3.58 & off & $<0.02^{\mathrm{x}}$ & 0.060 & --- \\
\hline & 39 & $\mathrm{~V} 2-10 \mathrm{~b}$ & 4.86 & 4.8 & 3.58 & off & $<0.02^{\mathrm{x}}$ & 0.26 & --- \\
\hline & 40 & $\mathrm{~V} 2-10 \mathrm{c}$ & 4.86 & 4.8 & 3.58 & off & $<0.02^{\mathrm{x}}$ & 0.074 & --- \\
\hline & 41 & $\mathrm{~V} 2-11$ & 5.63 & 10.2 & 3.60 & off & $<0.02^{\mathrm{x}}$ & $<0.02^{\mathrm{x}}$ & --- \\
\hline & 42 & $\mathrm{~V} 2-12$ & 6.03 & 15.0 & 3.60 & off & $<0.02^{\mathrm{x}}$ & $<0.02^{\mathrm{x}}$ & --- \\
\hline & 43 & $\mathrm{~V} 2-13$ & 6.33 & 20.8 & 3.58 & off & $<0.02^{\mathrm{x}}$ & $<0.02^{\mathrm{x}}$ & --- \\
\hline & 44 & $\mathrm{~V} 2-14$ & 6.53 & 25.5 & 3.60 & off & $<0.02^{\mathrm{x}}$ & $<0.02^{\mathrm{x}}$ & --- \\
\hline & 45 & $\mathrm{~V} 2-15$ & 6.93 & 30.0 & 3.56 & off & $<0.02^{\mathrm{x}}$ & $<0.02^{\mathrm{x}}$ & --- \\
\hline & 46 & $\mathrm{~V} 2-16 a$ & 7.13 & 36.2 & 3.56 & off & $<0.02^{\mathrm{x}}$ & $<0.02^{\mathrm{x}}$ & --- \\
\hline & 47 & $\mathrm{~V} 2-16 b$ & 7.13 & 36.2 & 3.56 & off & $<0.02^{\mathrm{x}}$ & $<0.02^{\mathrm{x}}$ & --- \\
\hline & 48 & $\mathrm{~V} 2-16 \mathrm{c}$ & 7.13 & 36.2 & 3.56 & off & $<0.02^{\mathrm{x}}$ & $<0.02^{\mathrm{x}}$ & --- \\
\hline \multirow{16}{*}{ 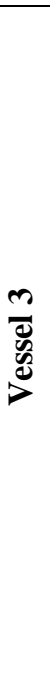 } & 49 & V3 - 1a & 0 & 17.9 & 3.07 & off & $<0.02^{\mathrm{x}}$ & 2.3 & 10.15 \\
\hline & 50 & $V 3-1 b$ & 0 & 17.9 & 3.07 & off & $<0.02^{\mathrm{x}}$ & 2.3 & 9.160 \\
\hline & 51 & $\mathrm{~V} 3-1 \mathrm{c}$ & 0 & 17.9 & 3.07 & off & $<0.02^{\mathrm{x}}$ & 2.3 & 35.53 \\
\hline & 52 & V3 - 2 & 1.00 & 25.0 & 3.07 & off & $<0.02^{\mathrm{x}}$ & 2.3 & 54.45 \\
\hline & 53 & V3 - 3 & 1.42 & 30.0 & 3.05 & off & $<0.02^{\mathrm{x}}$ & 2.5 & 59.24 \\
\hline & 54 & V3 - 4 & 2.55 & 35.1 & 3.03 & off & $<0.02^{\mathrm{x}}$ & 2.2 & 61.83 \\
\hline & 55 & V3 - 5a & 3.08 & 29.1 & 3.06 & off & $<0.02^{\mathrm{x}}$ & 2.3 & 60.29 \\
\hline & 56 & $V 3-5 b$ & 3.08 & 29.1 & 3.06 & off & $<0.02^{\mathrm{x}}$ & 2.4 & 60.03 \\
\hline & 57 & $V 3-5 c$ & 3.08 & 29.1 & 3.06 & off & $<0.02^{\mathrm{x}}$ & 2.4 & 59.08 \\
\hline & 58 & V3 - 6 & 3.88 & 24.6 & 3.08 & off & $<0.02^{\mathrm{x}}$ & 2.4 & 51.36 \\
\hline & 59 & V3 - 7 & 4.16 & 20.0 & 3.09 & off & $<0.02^{\mathrm{x}}$ & 2.3 & 46.14 \\
\hline & 60 & V3 - 8 & 4.53 & 15.0 & 3.12 & off & $<0.02^{\mathrm{x}}$ & 2.3 & 43.73 \\
\hline & 61 & V3 - 9 & 4.83 & 10.0 & 3.12 & off & $<0.02^{\mathrm{x}}$ & 2.3 & 42.96 \\
\hline & 62 & V3 - 10a & 5.28 & 5.0 & 3.16 & off & $<0.02^{\mathrm{x}}$ & 2.2 & 43.08 \\
\hline & 63 & $\mathrm{~V} 3-10 \mathrm{~b}$ & 5.28 & 5.0 & 3.16 & off & $<0.02^{\mathrm{x}}$ & 2.2 & 42.04 \\
\hline & 64 & $V 3-10 c$ & 5.28 & 5.0 & 3.16 & off & $<0.02^{\mathrm{x}}$ & 2.3 & 40.63 \\
\hline
\end{tabular}


Appendix C-6. Cycle 6 (2/28/2015) Data Continued

\begin{tabular}{|c|c|c|c|c|c|c|c|c|c|}
\hline & $\begin{array}{c}\text { Sample } \\
\text { No. }\end{array}$ & $\begin{array}{c}\text { Sample } \\
\text { Name }\end{array}$ & $\begin{array}{c}\text { Elapsed time } \\
(\mathrm{hr})\end{array}$ & $\begin{array}{c}\text { Temp. }^{+} \\
\left({ }^{\circ} \mathrm{C}\right)\end{array}$ & $\mathbf{p H}^{+}$ & $\begin{array}{c}\text { Light } \\
\text { (on/off) }\end{array}$ & $\begin{array}{c}\mathrm{Fe}^{\mathrm{II}^{*}} \\
(\mathrm{mg} / \mathrm{L})\end{array}$ & $\begin{array}{c}\mathrm{Fe}(\text { total }) \\
(\mathrm{mg} / \mathrm{L})\end{array}$ & $\begin{array}{l}\mathrm{Se}^{\mathrm{IVN*}} \\
(\mu \mathrm{g} / \mathrm{L})\end{array}$ \\
\hline \multirow{8}{*}{ 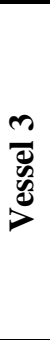 } & 65 & V3 - 11 & 6.00 & 10.2 & 3.13 & off & $<0.02^{\mathrm{x}}$ & 2.4 & 38.62 \\
\hline & 66 & V3 - 12 & 6.45 & 15.1 & 3.08 & off & $<0.02^{\mathrm{x}}$ & 2.4 & 37.21 \\
\hline & 67 & V3 - 13 & 6.65 & 20.2 & 3.06 & off & $<0.02^{\mathrm{x}}$ & 2.4 & 37.89 \\
\hline & 68 & V3 - 14 & 6.85 & 25.0 & 3.05 & off & $<0.02^{\mathrm{x}}$ & 2.4 & 23.87 \\
\hline & 69 & V3 - 15 & 7.18 & 30.0 & 3.05 & off & $<0.02^{\mathrm{x}}$ & 2.4 & 35.64 \\
\hline & 70 & V3 - 16a & 7.38 & 35.0 & 3.03 & off & $<0.02^{\mathrm{x}}$ & 2.4 & 37.84 \\
\hline & 71 & $V 3-16 b$ & 7.38 & 35.0 & 3.03 & off & $<0.02^{\mathrm{x}}$ & 2.3 & 37.27 \\
\hline & 72 & V3 - 16c & 7.38 & 35.0 & 3.03 & off & $<0.02^{\mathrm{x}}$ & 2.4 & 39.76 \\
\hline \multirow{20}{*}{ 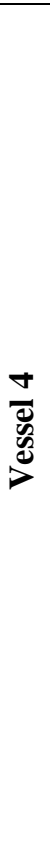 } & 73 & $\mathrm{~V} 4-1 \mathrm{a}$ & 0 & 18.1 & 3.36 & off & $<0.02^{\mathrm{x}}$ & 0.35 & 57.20 \\
\hline & 74 & $\mathrm{~V} 4-1 \mathrm{~b}$ & 0 & 18.1 & 3.36 & off & $<0.02^{\mathrm{x}}$ & 0.32 & 54.49 \\
\hline & 75 & V4 - 1c & 0 & 18.1 & 3.36 & off & $<0.02^{\mathrm{x}}$ & 0.33 & 59.77 \\
\hline & 76 & V4 - 2 & 1.00 & 25.0 & 3.33 & off & $<0.02^{\mathrm{x}}$ & 0.33 & 35.67 \\
\hline & 77 & V4 - 3 & 1.50 & 30.0 & 3.29 & off & $<0.02^{\mathrm{x}}$ & 0.30 & 36.62 \\
\hline & 78 & V4 - 4 & 1.57 & 35.8 & 3.30 & off & $<0.02^{\mathrm{x}}$ & 0.22 & 35.92 \\
\hline & 79 & V4 - 5a & 2.27 & 27.6 & 3.28 & off & $<0.02^{\mathrm{x}}$ & 0.32 & 41.91 \\
\hline & 80 & V4 - 5b & 2.27 & 27.6 & 3.28 & off & $<0.02^{\mathrm{x}}$ & 0.32 & 38.66 \\
\hline & 81 & $\mathrm{~V} 4-5 \mathrm{c}$ & 2.27 & 27.6 & 3.28 & off & $<0.02^{\mathrm{x}}$ & 0.36 & 38.86 \\
\hline & 82 & V4 - 6 & 2.92 & 23.7 & 3.32 & off & $<0.02^{\mathrm{x}}$ & 0.30 & 38.23 \\
\hline & 83 & V4 - 7 & 3.85 & 20.0 & 3.32 & off & $<0.02^{\mathrm{x}}$ & 0.30 & 32.47 \\
\hline & 84 & V4 - 8 & 4.22 & 15.0 & 3.34 & off & $<0.02^{\mathrm{x}}$ & 0.22 & 30.99 \\
\hline & 85 & V4 - 9 & 4.62 & 10.0 & 3.38 & off & $<0.02^{\mathrm{x}}$ & 0.25 & 31.08 \\
\hline & 86 & $\mathrm{~V} 4-10 \mathrm{a}$ & 5.22 & 6.1 & 3.43 & off & $<0.02^{\mathrm{x}}$ & 0.22 & 30.45 \\
\hline & 87 & $\mathrm{~V} 4-10 \mathrm{~b}$ & 5.22 & 6.1 & 3.43 & off & $<0.02^{\mathrm{x}}$ & 0.22 & 30.50 \\
\hline & 88 & $\mathrm{~V} 4-10 \mathrm{c}$ & 5.22 & 6.1 & 3.43 & off & $<0.02^{\mathrm{x}}$ & 0.23 & 30.69 \\
\hline & 89 & V4 - 11 & 5.82 & 10.4 & 3.37 & off & $<0.02^{\mathrm{x}}$ & 0.20 & 26.87 \\
\hline & 90 & V4 - 12 & 6.02 & 15.1 & 3.36 & off & $<0.02^{\mathrm{x}}$ & 0.22 & 48.13 \\
\hline & 91 & V4 - 13 & 6.42 & 20.1 & 3.36 & off & $<0.02^{\mathrm{x}}$ & 0.20 & 47.75 \\
\hline & 92 & V4 - 14 & 6.64 & 25.4 & 3.32 & off & $<0.02^{\mathrm{x}}$ & 0.20 & 45.91 \\
\hline
\end{tabular}


Appendix C-6. Cycle 6 (2/28/2015) Data Continued

\begin{tabular}{|c|c|c|c|c|c|c|c|c|c|}
\hline & $\begin{array}{c}\text { Sample } \\
\text { No. }\end{array}$ & $\begin{array}{c}\text { Sample } \\
\text { Name }\end{array}$ & $\begin{array}{c}\text { Elapsed time } \\
(\mathrm{hr})\end{array}$ & $\begin{array}{c}\text { Temp. }^{+} \\
\left({ }^{\circ} \mathrm{C}\right)\end{array}$ & $\mathbf{p H}^{+}$ & $\begin{array}{c}\text { Light } \\
\text { (on/off) }\end{array}$ & $\begin{array}{c}\mathrm{Fe}^{\mathrm{II}^{*}} \\
(\mathrm{mg} / \mathrm{L})\end{array}$ & $\begin{array}{c}\mathrm{Fe}(\text { total })^{*} \\
(\mathrm{mg} / \mathrm{L})\end{array}$ & $\begin{array}{l}\mathrm{Se}^{\mathrm{I} \mathrm{I}^{* * *}} \\
(\mu \mathrm{g} / \mathrm{L})\end{array}$ \\
\hline \multirow{4}{*}{ 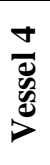 } & 93 & $\mathrm{~V} 4-15$ & 6.92 & 30.6 & 3.32 & off & $<0.02^{x}$ & 0.20 & 44.73 \\
\hline & 94 & V4 - 16a & 7.05 & 35.1 & 3.32 & off & $<0.02^{\mathrm{x}}$ & 0.19 & 45.47 \\
\hline & 95 & $\mathrm{~V} 4-16 \mathrm{~b}$ & 7.05 & 35.1 & 3.32 & off & $<0.02^{\mathrm{x}}$ & 0.20 & 47.76 \\
\hline & 96 & $\mathrm{~V} 4-16 \mathrm{c}$ & 7.05 & 35.1 & 3.32 & off & $<0.02^{\mathrm{x}}$ & 0.20 & 47.05 \\
\hline
\end{tabular}

${ }^{\mp}$ Measured using DrDAQ PicoLog Recorder

* Samples analyzed using HACH DR2800 Spectrophotometer

** Samples analyzed using HG-ICP-OES

${ }^{x}$ Sample below ferrozine MDL of $0.02 \mathrm{mg} / \mathrm{L}$ for $\mathrm{Fe}^{\mathrm{II}}$ and $\mathrm{Fe}$ (total)

${ }^{\mathrm{x}}$ Sample below HG-ICP-OES MDL of $5 \mu \mathrm{g} / \mathrm{L}$ for $\mathrm{Se}^{\mathrm{IV}}$

--- Sample not analyzed

Sample names including a,b,c are triplicate samples 
Appendix C-7. Cycle 7 (4/26/2015) Data

\begin{tabular}{|c|c|c|c|c|c|c|c|c|}
\hline & $\begin{array}{c}\text { Sample } \\
\text { No. }\end{array}$ & $\begin{array}{c}\text { Sample } \\
\text { Name }\end{array}$ & $\begin{array}{c}\text { Elapsed time } \\
(\mathrm{hr})\end{array}$ & $\begin{array}{c}\text { Temp. }^{+} \\
\left({ }^{\circ} \mathrm{C}\right)\end{array}$ & $\mathbf{p} \mathbf{H}^{+}$ & $\begin{array}{c}\text { Light } \\
\text { (on/off) }\end{array}$ & $\begin{array}{c}\text { Light Intensity }^{++} \\
(\text {Lux })\end{array}$ & $\begin{array}{l}\mathrm{Se}^{\mathrm{IV**}} \\
(\mu \mathrm{g} / \mathrm{L})\end{array}$ \\
\hline \multirow{27}{*}{$\begin{array}{l}\bar{D} \\
\overline{0} \\
\dot{0}\end{array}$} & 1 & $\mathrm{~V} 1-1 \mathrm{a}$ & 0 & 24.1 & 2.83 & on & 118.4 & 338.6 \\
\hline & 2 & $\mathrm{~V} 1-1 \mathrm{~b}$ & 0 & 24.1 & 2.83 & on & 118.4 & 351.2 \\
\hline & 3 & $\mathrm{~V} 1-1 \mathrm{c}$ & 0 & 24.1 & 2.83 & on & 118.4 & 351.1 \\
\hline & 4 & V1 - 2 & 0.50 & 29.9 & 2.83 & on & 118.4 & 350.6 \\
\hline & 5 & $\mathrm{~V} 1-3 \mathrm{a}$ & 1.00 & 35.0 & 2.83 & on & 113.0 & 370.5 \\
\hline & 6 & V1 - 3b & 1.00 & 35.0 & 2.83 & on & 113.0 & 376.5 \\
\hline & 7 & $\mathrm{~V} 1-3 \mathrm{c}$ & 1.00 & 35.0 & 2.83 & on & 113.0 & 373.6 \\
\hline & 8 & V1 - 4 & 1.77 & 30.0 & 2.82 & on & 113.0 & 361.7 \\
\hline & 9 & V1 - 5a & 2.25 & 25.0 & 2.82 & on & 113.0 & 363.9 \\
\hline & 10 & $\mathrm{~V} 1-5 b$ & 2.25 & 25.0 & 2.82 & on & 113.0 & 370.8 \\
\hline & 11 & $\mathrm{~V} 1-5 \mathrm{c}$ & 2.25 & 25.0 & 2.82 & on & 113.0 & 355.5 \\
\hline & 12 & V1 - 6 & 2.63 & 20.0 & 2.83 & on & 113.0 & 358.4 \\
\hline & 13 & V1 - 7 & 3.21 & 15.0 & 2.83 & on & 107.7 & 357.3 \\
\hline & 14 & V1 - 8 & 3.91 & 10.0 & 2.84 & on & 107.7 & 349.3 \\
\hline & 15 & V1 - 9a & 4.38 & 6.6 & 2.88 & on & 107.7 & 352.5 \\
\hline & 16 & $\mathrm{~V} 1-9 b$ & 4.38 & 6.6 & 2.88 & on & 107.7 & 337.2 \\
\hline & 17 & $\mathrm{~V} 1-9 \mathrm{c}$ & 4.38 & 6.6 & 2.88 & on & 107.7 & 343.5 \\
\hline & 18 & V1 - 10 & 4.75 & 10.2 & 2.88 & on & 107.7 & 363.0 \\
\hline & 19 & V1 - 11 & 5.13 & 15.0 & 2.83 & on & 107.7 & 367.0 \\
\hline & 20 & V1 - 12 & 5.66 & 20.0 & 2.81 & on & 102.3 & 356.8 \\
\hline & 21 & $\mathrm{~V} 1-13 a$ & 6.09 & 25.0 & 2.81 & on & 102.3 & 374.0 \\
\hline & 22 & $V 1-13 b$ & 6.09 & 25.0 & 2.81 & on & 102.3 & 360.4 \\
\hline & 23 & $\mathrm{~V} 1-13 \mathrm{c}$ & 6.09 & 25.0 & 2.81 & on & 102.3 & 361.9 \\
\hline & 24 & V1 - 14 & 6.64 & 30.0 & 2.80 & on & 102.3 & 374.6 \\
\hline & 25 & $\mathrm{~V} 1-15 \mathrm{a}$ & 7.07 & 35.1 & 2.80 & on & 118.4 & 388.4 \\
\hline & 26 & $\mathrm{~V} 1-15 b$ & 7.07 & 35.1 & 2.80 & on & 50.6 & 375.2 \\
\hline & 27 & $\mathrm{~V} 1-15 \mathrm{c}$ & 7.07 & 35.1 & 2.80 & on & 118.4 & 376.9 \\
\hline \multirow{5}{*}{$\begin{array}{l}\frac{N}{d} \\
\dot{D} \\
\dot{D}\end{array}$} & 28 & $\mathrm{~V} 2-1 \mathrm{a}$ & 0 & 24.1 & 2.86 & on & 118.4 & 351.0 \\
\hline & 29 & $\mathrm{~V} 2-1 \mathrm{~b}$ & 0 & 24.1 & 2.86 & on & 118.4 & 355.6 \\
\hline & 30 & $\mathrm{~V} 2-1 \mathrm{c}$ & 0 & 24.1 & 2.86 & on & 118.4 & 358.7 \\
\hline & 31 & $\mathrm{~V} 2-2$ & 0.50 & 30.0 & 2.86 & on & 118.4 & 365.4 \\
\hline & 32 & $\mathrm{~V} 2-3 \mathrm{a}$ & 1.27 & 35.0 & 2.87 & on & 113.0 & 358.8 \\
\hline
\end{tabular}


Appendix C-7. Cycle 7 (4/26/2015) Data Continued

\begin{tabular}{|c|c|c|c|c|c|c|c|c|}
\hline & $\begin{array}{c}\text { Sample } \\
\text { No. }\end{array}$ & $\begin{array}{c}\text { Sample } \\
\text { Name }\end{array}$ & $\begin{array}{c}\text { Elapsed time } \\
(\mathrm{hr})\end{array}$ & $\begin{array}{c}\text { Temp. }^{+} \\
\left({ }^{\circ} \mathrm{C}\right)\end{array}$ & $\mathbf{p H}^{+}$ & $\begin{array}{c}\text { Light } \\
\text { (on/off) }\end{array}$ & $\begin{array}{c}\text { Light Intensity }^{++} \\
\text {(Lux) }\end{array}$ & $\begin{array}{l}\mathrm{Se}^{\mathrm{IN**}} \\
(\mu \mathrm{g} / \mathrm{L}) \\
\end{array}$ \\
\hline \multirow{22}{*}{ 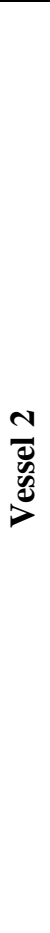 } & 33 & $V 2-3 b$ & 1.27 & 35.0 & 2.87 & on & 113.0 & 362.1 \\
\hline & 34 & $\mathrm{~V} 2-3 \mathrm{c}$ & 1.27 & 35.0 & 2.87 & on & 113.0 & 357.3 \\
\hline & 35 & $\mathrm{~V} 2-4$ & 1.84 & 30.0 & 2.86 & on & 113.0 & 360.8 \\
\hline & 36 & $V 2-5 a$ & 2.26 & 25.1 & 2.87 & on & 113.0 & 368.3 \\
\hline & 37 & $\mathrm{~V} 2-5 b$ & 2.26 & 25.1 & 2.87 & on & 113.0 & 357.2 \\
\hline & 38 & $\mathrm{~V} 2-5 \mathrm{c}$ & 2.26 & 25.1 & 2.87 & on & 113.0 & 362.3 \\
\hline & 39 & $\mathrm{~V} 2-6$ & 2.76 & 20.0 & 2.87 & on & 113.0 & 361.7 \\
\hline & 40 & $\mathrm{~V} 2-7$ & 3.28 & 15.0 & 2.86 & on & 107.7 & 349.1 \\
\hline & 41 & $\mathrm{~V} 2-8$ & 3.98 & 10.0 & 2.87 & on & 107.7 & 344.4 \\
\hline & 42 & $\mathrm{~V} 2-9 \mathrm{a}$ & 4.41 & 7.3 & 2.86 & on & 107.7 & 343.8 \\
\hline & 43 & $\mathrm{~V} 2-9 \mathrm{~b}$ & 4.41 & 7.3 & 2.86 & on & 107.7 & 346.6 \\
\hline & 44 & $\mathrm{~V} 2-9 \mathrm{c}$ & 4.41 & 7.3 & 2.86 & on & 107.7 & 343.2 \\
\hline & 45 & $\mathrm{~V} 2-10$ & 4.76 & 10.0 & 2.86 & on & 107.7 & 354.0 \\
\hline & 46 & $\mathrm{~V} 2-11$ & 5.18 & 15.0 & 2.86 & on & 107.7 & 369.9 \\
\hline & 47 & $\mathrm{~V} 2-12$ & 5.65 & 20.0 & 2.85 & on & 102.3 & 356.6 \\
\hline & 48 & $V 2-13 a$ & 6.10 & 25.0 & 2.86 & on & 102.3 & 370.1 \\
\hline & 49 & $V 2-13 b$ & 6.10 & 25.0 & 2.86 & on & 102.3 & 363.9 \\
\hline & 50 & $V 2-13 c$ & 6.10 & 25.0 & 2.86 & on & 102.3 & 365.7 \\
\hline & 51 & V2 - 14 & 6.72 & 30.0 & 2.86 & on & 102.3 & 365.6 \\
\hline & 52 & $\mathrm{~V} 2-15 \mathrm{a}$ & 7.10 & 35.2 & 2.86 & on & 118.4 & 382.1 \\
\hline & 53 & $V 2-15 b$ & 7.10 & 35.2 & 2.86 & on & 50.6 & 377.2 \\
\hline & 54 & $\mathrm{~V} 2-15 \mathrm{c}$ & 7.10 & 35.2 & 2.86 & on & 118.4 & 376.3 \\
\hline \multirow{10}{*}{ 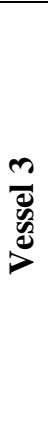 } & 55 & $\mathrm{~V} 3-1 \mathrm{a}$ & 0 & 24.3 & 2.87 & on & 118.4 & 364.2 \\
\hline & 56 & V3 - 1b & 0 & 24.3 & 2.87 & on & 118.4 & 361.5 \\
\hline & 57 & V3 - 1c & 0 & 24.3 & 2.87 & on & 118.4 & 368.0 \\
\hline & 58 & V3 - 2 & 0.50 & 30.5 & 2.86 & on & 118.4 & 361.1 \\
\hline & 59 & $\mathrm{~V} 3-3 \mathrm{a}$ & 1.12 & 35.0 & 2.85 & on & 113.0 & 382.8 \\
\hline & 60 & $\mathrm{~V} 3-3 \mathrm{~b}$ & 1.12 & 35.0 & 2.85 & on & 113.0 & 386.4 \\
\hline & 61 & $\mathrm{~V} 3-3 \mathrm{c}$ & 1.12 & 35.0 & 2.85 & on & 113.0 & 378.6 \\
\hline & 62 & V3 - 4 & 1.84 & 30.0 & 2.86 & on & 113.0 & 382.1 \\
\hline & 63 & $\mathrm{~V} 3-5 \mathrm{a}$ & 2.26 & 25.1 & 2.86 & on & 113.0 & 371.8 \\
\hline & 64 & $\mathrm{~V} 3-5 \mathrm{~b}$ & 2.26 & 25.1 & 2.86 & on & 113.0 & 377.1 \\
\hline
\end{tabular}


Appendix C-7. Cycle 7 (4/26/2015) Data Continued

\begin{tabular}{|c|c|c|c|c|c|c|c|c|}
\hline & $\begin{array}{c}\text { Sample } \\
\text { No. }\end{array}$ & $\begin{array}{l}\text { Sample } \\
\text { Name }\end{array}$ & $\begin{array}{c}\text { Elapsed time } \\
(\mathrm{hr})\end{array}$ & $\begin{array}{c}\text { Temp. }^{+} \\
\left({ }^{\circ} \mathrm{C}\right)\end{array}$ & $\mathbf{p H}^{+}$ & $\begin{array}{c}\text { Light } \\
\text { (on/off) }\end{array}$ & $\begin{array}{c}\text { Light Intensity }^{++} \\
\text {(Lux) }\end{array}$ & $\begin{array}{l}\mathrm{Se}^{\mathrm{INF*}^{\text {N*F}}} \\
(\mu \mathrm{g} / \mathrm{L})\end{array}$ \\
\hline \multirow{17}{*}{ 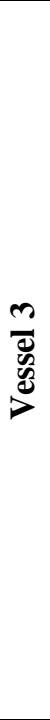 } & 65 & $V 3-5 c$ & 2.26 & 25.1 & 2.86 & on & 113.0 & 386.1 \\
\hline & 66 & V3 - 6 & 2.73 & 20.0 & 2.86 & on & 113.0 & 364.1 \\
\hline & 67 & V3 - 7 & 3.26 & 15.0 & 2.87 & on & 107.7 & 357.1 \\
\hline & 68 & V3 - 8 & 3.96 & 10.0 & 2.90 & on & 107.7 & 364.2 \\
\hline & 69 & V3 - 9a & 4.43 & 6.7 & 2.95 & on & 107.7 & 355.0 \\
\hline & 70 & $V 3-9 b$ & 4.43 & 6.7 & 2.95 & on & 107.7 & 352.7 \\
\hline & 71 & $V 3-9 c$ & 4.43 & 6.7 & 2.95 & on & 107.7 & 353.4 \\
\hline & 72 & V3 - 10 & 4.78 & 10.2 & 2.94 & on & 107.7 & 365.7 \\
\hline & 73 & V3 - 11 & 5.15 & 15.0 & 2.89 & on & 107.7 & 372.9 \\
\hline & 74 & V3 - 12 & 5.63 & 20.0 & 2.87 & on & 102.3 & 374.1 \\
\hline & 75 & $\mathrm{~V} 3-13 \mathrm{a}$ & 6.08 & 25.0 & 2.87 & on & 102.3 & 376.8 \\
\hline & 76 & V3 - 13b & 6.08 & 25.0 & 2.87 & on & 102.3 & 374.1 \\
\hline & 77 & $V 3-13 c$ & 6.08 & 25.0 & 2.87 & on & 102.3 & 368.4 \\
\hline & 78 & V3 - 14 & 6.66 & 30.0 & 2.87 & on & 102.3 & 374.7 \\
\hline & 79 & $V 3-15 a$ & 7.09 & 35.2 & 2.87 & on & 118.4 & 383.1 \\
\hline & 80 & $\mathrm{~V} 3-15 b$ & 7.09 & 35.2 & 2.87 & on & 50.6 & 389.8 \\
\hline & 81 & $V 3-15 c$ & 7.09 & 35.2 & 2.87 & on & 118.4 & 388.5 \\
\hline \multirow{15}{*}{ 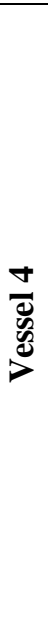 } & 82 & $\mathrm{~V} 4-1 \mathrm{a}$ & 0 & 24.1 & 2.79 & on & 118.4 & 378.5 \\
\hline & 83 & $\mathrm{~V} 4-1 \mathrm{~b}$ & 0 & 24.1 & 2.79 & on & 118.4 & 386.4 \\
\hline & 84 & V4 - 1c & 0 & 24.1 & 2.79 & on & 118.4 & 374.9 \\
\hline & 85 & V4 - 2 & 0.50 & 30.0 & 2.79 & on & 118.4 & 381.0 \\
\hline & 86 & $\mathrm{~V} 4-3 \mathrm{a}$ & 1.25 & 35.0 & 2.79 & on & 113.0 & 393.6 \\
\hline & 87 & V4 - 3b & 1.25 & 35.0 & 2.79 & on & 113.0 & --- \\
\hline & 88 & V4 - 3c & 1.25 & 35.0 & 2.79 & on & 113.0 & 389.0 \\
\hline & 89 & V4 - 4 & 1.83 & 30.0 & 2.79 & on & 113.0 & 380.3 \\
\hline & 90 & V4 - 5a & 2.26 & 25.0 & 2.79 & on & 113.0 & 383.4 \\
\hline & 91 & V4 - 5b & 2.26 & 25.0 & 2.79 & on & 113.0 & 382.6 \\
\hline & 92 & V4 - 5c & 2.26 & 25.0 & 2.79 & on & 113.0 & 396.0 \\
\hline & 93 & V4 - 6 & 2.69 & 20.0 & 2.80 & on & 113.0 & 387.3 \\
\hline & 94 & V4 - 7 & 3.26 & 15.0 & 2.84 & on & 107.7 & 375.5 \\
\hline & 95 & V4 - 8 & 3.98 & 10.0 & 2.87 & on & 107.7 & 380.6 \\
\hline & 96 & V4 - 9a & 4.41 & 7.4 & 2.91 & on & 107.7 & 369.5 \\
\hline
\end{tabular}


Appendix C-7. Cycle 7 (4/26/2015) Data Continued

\begin{tabular}{|c|c|c|c|c|c|c|c|c|}
\hline & $\begin{array}{c}\text { Sample } \\
\text { No. }\end{array}$ & $\begin{array}{c}\text { Sample } \\
\text { Name }\end{array}$ & $\begin{array}{c}\begin{array}{c}\text { Elapsed time } \\
(\mathrm{hr})\end{array} \\
\end{array}$ & $\begin{array}{c}\text { Temp. }^{+} \\
\left({ }^{\circ} \mathrm{C}\right)\end{array}$ & $\mathbf{p H}^{+}$ & $\begin{array}{c}\text { Light } \\
\text { (on/off) }\end{array}$ & $\begin{array}{c}\text { Light Intensity }^{++} \\
\text {(Lux) }\end{array}$ & $\begin{array}{l}\mathrm{Se}^{\mathrm{IV**}} \\
(\mu \mathrm{g} / \mathrm{L})\end{array}$ \\
\hline \multirow{12}{*}{ 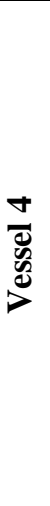 } & 97 & $\mathrm{~V} 4-9 \mathrm{~b}$ & 4.41 & 7.4 & 2.91 & on & 107.7 & 363.9 \\
\hline & 98 & $\mathrm{~V} 4-9 \mathrm{c}$ & 4.41 & 7.4 & 2.91 & on & 107.7 & 367.6 \\
\hline & 99 & V4 - 10 & 4.78 & 10.1 & 2.91 & on & 107.7 & 367.7 \\
\hline & 100 & V4 - 11 & 5.11 & 15.0 & 2.85 & on & 107.7 & 383.4 \\
\hline & 101 & V4 - 12 & 5.73 & 20.0 & 2.82 & on & 102.3 & 384.8 \\
\hline & 102 & V4 - 13a & 6.08 & 25.0 & 2.80 & on & 102.3 & 382.4 \\
\hline & 103 & $\mathrm{~V} 4-13 b$ & 6.08 & 25.0 & 2.80 & on & 102.3 & 389.8 \\
\hline & 104 & $\mathrm{~V} 4-13 \mathrm{c}$ & 6.08 & 25.0 & 2.80 & on & 102.3 & 385.9 \\
\hline & 105 & V4 - 14 & 6.66 & 30.0 & 2.79 & on & 102.3 & 390.3 \\
\hline & 106 & V4 - 15a & 7.08 & 35.2 & 2.80 & on & 118.4 & 397.9 \\
\hline & 107 & $\mathrm{~V} 4-15 b$ & 7.08 & 35.2 & 2.80 & on & 50.6 & 412.5 \\
\hline & 108 & $V 4-15 c$ & 7.08 & 35.2 & 2.80 & on & 118.4 & 397.1 \\
\hline
\end{tabular}

${ }^{+}$Measured using DrDAQ PicoLog Recorder

${ }^{++}$Measured using HOBO Pendant Light/Temperature Loggers

${ }^{* *}$ Samples analyzed using HG-ICP-OES (MDL of $5 \mu \mathrm{g} / \mathrm{L} \mathrm{Se}{ }^{\mathrm{IV}}$ )

--- Sample not analyzed

Sample names including a,b,c are triplicate samples 